\title{
Soil Response of Helicopter Liming in the Monongahela National Forest
}

Jarrett Douglas Fowler

West Virginia University, jdf0030@mix.wvu.edu

Follow this and additional works at: https://researchrepository.wvu.edu/etd

Part of the Agricultural Education Commons, Agricultural Science Commons, Aquaculture and Fisheries Commons, Earth Sciences Commons, Environmental Health and Protection Commons, Environmental Indicators and Impact Assessment Commons, Environmental Monitoring Commons, Environmental Studies Commons, Forest Management Commons, Natural Resources and Conservation Commons, Natural Resources Management and Policy Commons, Other Environmental Sciences Commons, Other Forestry and Forest Sciences Commons, Other Life Sciences Commons, Other Plant Sciences Commons, Outdoor Education Commons, Research Methods in Life Sciences Commons, and the Sustainability Commons

\section{Recommended Citation}

Fowler, Jarrett Douglas, "Soil Response of Helicopter Liming in the Monongahela National Forest" (2021). Graduate Theses, Dissertations, and Problem Reports. 8092.

https://researchrepository.wvu.edu/etd/8092

This Thesis is protected by copyright and/or related rights. It has been brought to you by the The Research Repository @ WVU with permission from the rights-holder(s). You are free to use this Thesis in any way that is permitted by the copyright and related rights legislation that applies to your use. For other uses you must obtain permission from the rights-holder(s) directly, unless additional rights are indicated by a Creative Commons license in the record and/ or on the work itself. This Thesis has been accepted for inclusion in WVU Graduate Theses, Dissertations, and Problem Reports collection by an authorized administrator of The Research Repository @ WVU. For more information, please contact researchrepository@mail.wvu.edu. 


\title{
Soil Response of Helicopter Liming in the Monongahela National Forest
}

\author{
Jarrett Douglas Fowler
}

Thesis submitted to the Davis College of Agriculture, Natural Resources, and Design at West Virginia University

In partial fulfillment of the requirements for the degree of

Master of Science in Environmental, Soil, \& Water Sciences

\author{
Jeff Skousen, Ph.D., Chair \\ Louis McDonald, Ph.D. \\ Jamie Schuler, Ph.D.
}

Division of Plant and Soil Sciences

Morgantown, WV

2021

Keywords: Liming, acid deposition, forest soils, acid forest soils, helicopter, Appalachian, West Virginia, Monongahela National Forest

Copyright 2021 Jarrett Douglas Fowler 


\section{Abstract \\ Soil Response of Helicopter Liming in the Monongahela National Forest Jarrett Douglas Fowler}

Soils in the Monongahela National Forest (MNF) are acidic due to sandstone parent material, acid deposition, uptake of base cations by vegetation, and release of organic acids by organic matter (OM) decomposition. Increases in soil acidity have caused declines in forest health and changed species composition and nutrient status. Liming can neutralize soil acidity, but no large-scale liming projects have been done on acid forest soils in the USA. In anticipation of acquiring funding for a proposed liming project in the MNF, in 2007 and 200910 sites were selected to sample and analyze soils before lime was applied. In 2018, funds were approved and a total of 284 ha (700 ac) were limed by helicopter in the MNF near Richwood, WV. Liming material particle size varied from small sand to small gravel chips and the liming rate was targeted for 6.7 to $11.2 \mathrm{Mg} / \mathrm{ha}$ ( 3 to 5 tons/ac). These same 10 sampling sites representing Limed and Unlimed areas were then resampled in 2019 (previous sampling dates were simplified to 2009) using the same procedures and analyses.

On Unlimed soils in 2019, $\mathrm{pH}$ in the $\mathrm{O}, \mathrm{A}$, and $\mathrm{B}$ horizons was 4.6, 4.3, and 4.8, respectively. Acidity values averaged 11,11 , and $7 \mathrm{cmol}+/ \mathrm{kg}$ and aluminum (Al) concentrations were high in these acid soils at 261, 627, and $464 \mathrm{mg} / \mathrm{kg}$ in O, A, and B horizons. Average $\mathrm{Ca}$ concentrations varied from $7.9,0.5$, and $0.1 \mathrm{cmol}+/ \mathrm{kg}$, while average \% organic matter (OM) ranged from 58,14 , and $7 \%$ in $\mathrm{O}, \mathrm{A}$, and $\mathrm{B}$ horizons. When comparing Unlimed sites sampled in 2009 and 2019, differences in measured parameters were small. In Limed soils in 2019, pH in the $\mathrm{O}, \mathrm{A}$, and $\mathrm{B}$ horizons was $5.9,4.6$, and 4.7 , a significant rise in the $\mathrm{O}$ horizon. Average acidity values were reduced by $73 \%$ in $O$ horizons, and less so in $A$ and $B$ horizons. Average $\mathrm{Al}$ concentrations were drastically reduced in $O$ and $A$ horizons $(261 \mathrm{mg} / \mathrm{kg}$ in 2009 to $58 \mathrm{mg} / \mathrm{kg}$ in 2019; $627 \mathrm{mg} / \mathrm{kg}$ in $2009 \mathrm{vs} 325 \mathrm{mg} / \mathrm{kg}$ in 2019), with similar values in the B horizon ( 475 $\mathrm{mg} / \mathrm{kg}$ ). Average Ca concentrations in 2019 Limed sites were at least three times higher at 27.2, 3.2 , and $0.4 \mathrm{cmol}+/ \mathrm{kg}$ in $\mathrm{O}, \mathrm{A}$, and $B$ horizons compared to Unlimed sites. Average concentrations for $\mathrm{K}, \mathrm{Mg}$, and $\mathrm{P}$ were very similar to Unlimed soils in $\mathrm{O}, \mathrm{A}$, and $\mathrm{B}$ horizons. Average ECEC values increased slightly in O horizons ( 33 compared to $22 \mathrm{cmol}+/ \mathrm{kg}$ ) due to liming but were similar in $A$ and $B$ horizons. Average OM values decreased from $58 \%$ to $35 \%$ in $O$ Horizons, but again, little change in A and B horizons. Based on these first-year results, liming had a significant effect on several properties in $\mathrm{O}$ and $\mathrm{A}$ horizons. However, lime particles in the $O$ horizon (which were observed during sampling of $O$ horizons) caused these increases in soil $\mathrm{pH}, \mathrm{Ca}, \mathrm{ECEC}$ concentrations, along with decreases in acidity and aluminum. These changes are an artificial effect due to collecting undissolved lime particles during our sampling. As lime dissolves and is integrated into the soil, these parameters will change and more accurately reflect the effect of the liming on the $\mathrm{O}$ and $\mathrm{A}$ horizons. 


\section{Acknowledgements:}

The author thanks Stephanie Connolly (USFS), Steffany Scagline-Mellor (USFS now NRCS), and Adrienne Nottingham (USFS) for their assistance throughout the research period of 20192021. The idea for this project was developed by the Gauley Ranger District of the Monongahela National Forest (MNF) of the USDA-Forest Service (USFS) in 2010. The soil samples from 2007 and 2009 were collected by forest soil scientists (Stephanie Connolly and associates) and this earlier data was made available to us for use in our study. Special thanks go to Ida Holaskova and Matthew Walker for their help and assistance during the countless hours of my statistical analysis and supporting discussions. I also thank Matthew for creating the code in R Studio and for his assistance with the Violin Plots to use as a visual aid for my data; I was first hesitant about the use of the Violin Plots but after actually seeing them and realizing how useful they were, I'm grateful to Matthew for helping me with them.

I would also like to thank Dr. Jeff Skousen for this opportunity to pursue graduate studies at West Virginia University. From having Dr. Skousen as a professor, I grew to respect both him and his work on a professional and personal level. I also appreciate Dr. Skousen for having high expectations and pushing me when I thought I had my limits.

Dr. Louis McDonald and Dr. Jamie Schuler, my other two committee members, also deserve recognition. I would like to thank Dr. Schuler for allowing me to enroll in his advanced silviculture class and helping me understand the importance of silviculture. I also thank Dr. McDonald for helping me understand the importance of soil fertility and making me aware of the many components that affect soil fertility.

I would also like to thank my entire family and my friends for their unwavering support and for their understanding during these past two years. 


\section{Table of Contents}

Abstract.

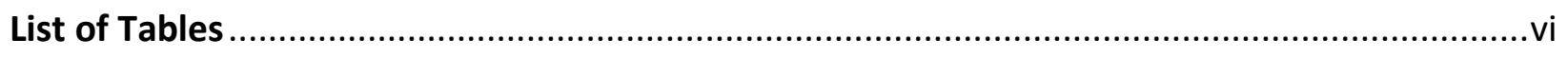

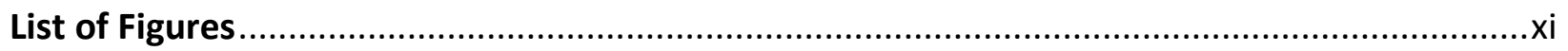

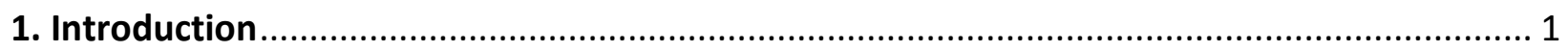

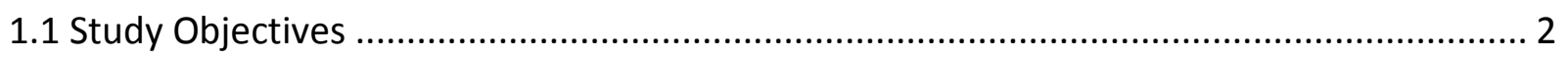

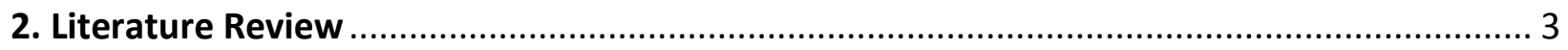

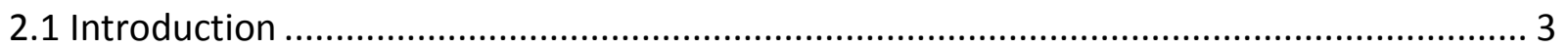

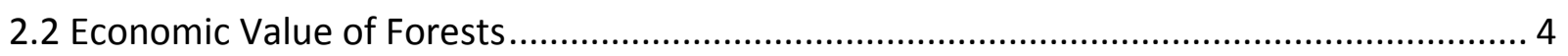

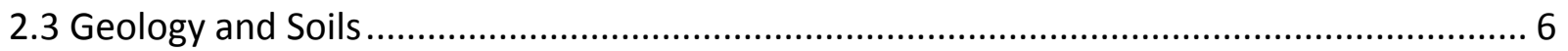

2.4 Coal Combustion and Acid Deposition ................................................................... 7

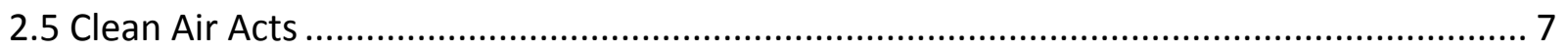

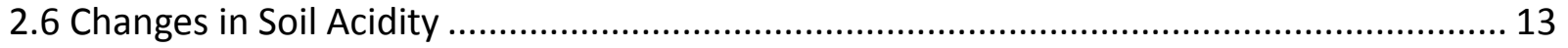

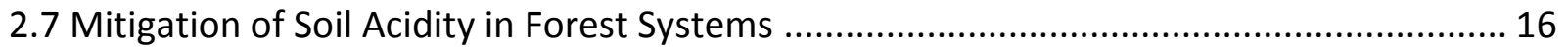

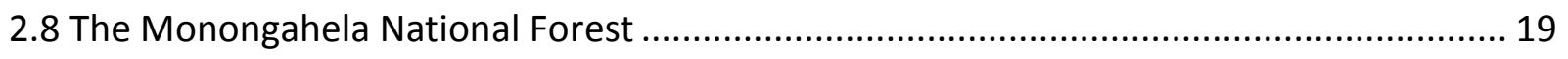

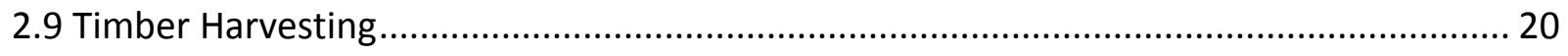

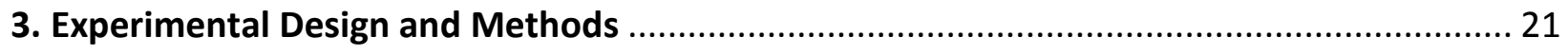

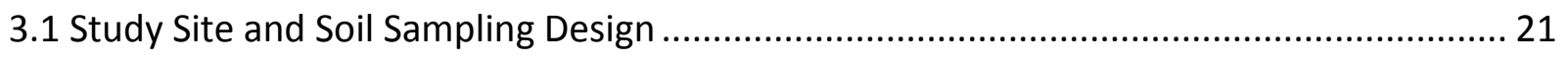

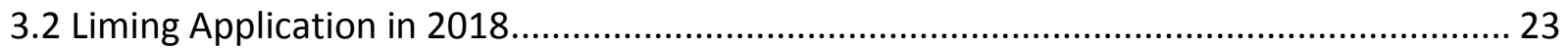

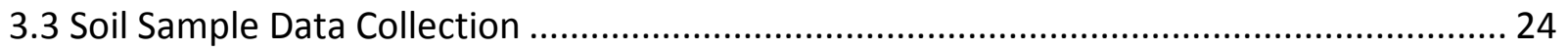

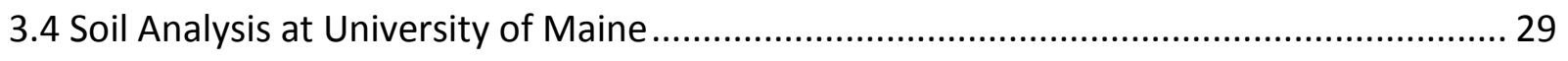

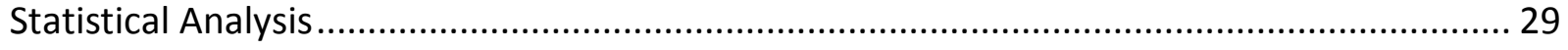

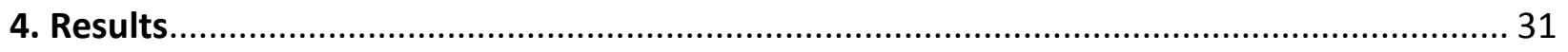

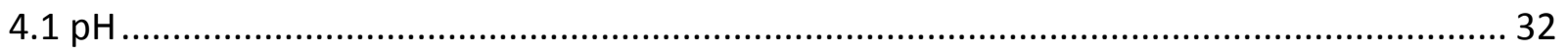

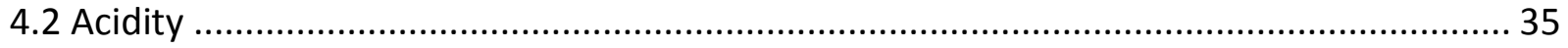

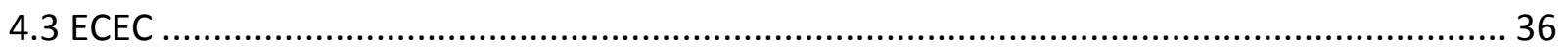

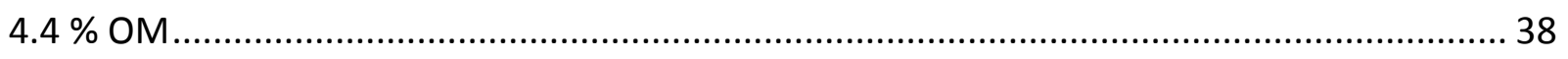

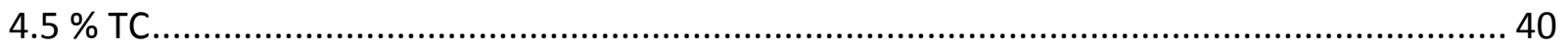

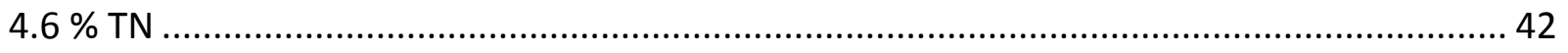

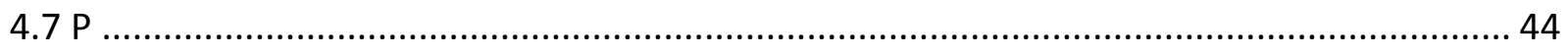

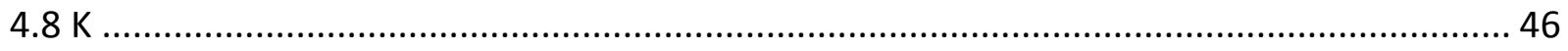


4.9 Са

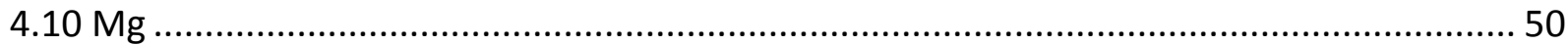

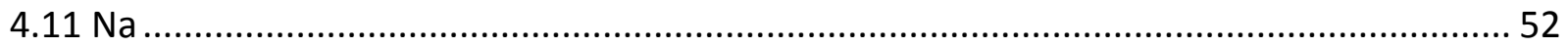

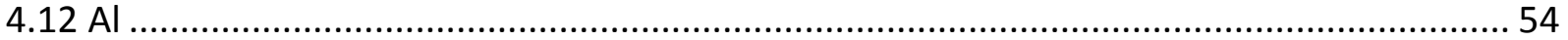

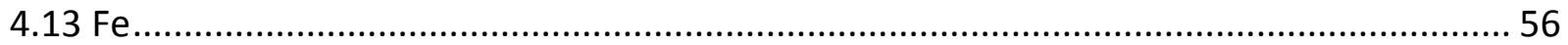

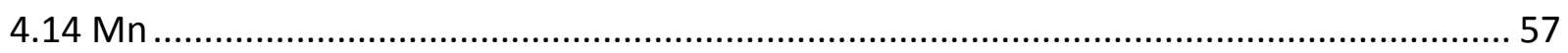

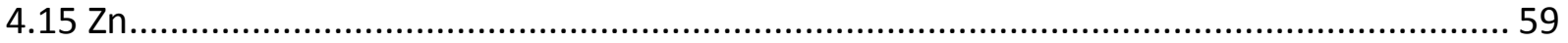

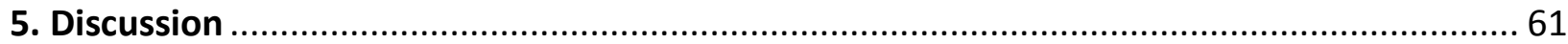

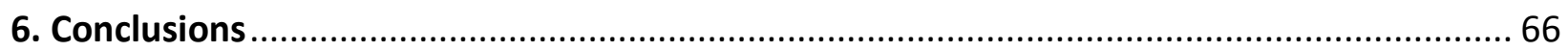

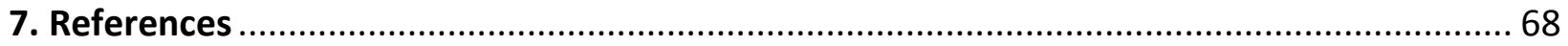

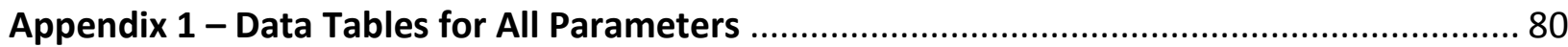

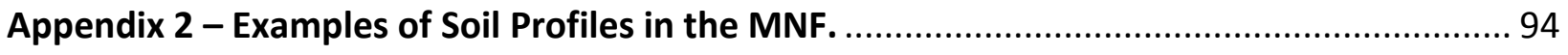

Appendix 3 - Examples of Field Sheets for Soil Descriptions.......................................... 104

Appendix 4 - All data from the MNF Liming Study for the years 2009 and 2019. .............. 105

Appendix 5 - Statistical Codes used for Analysis...................................................... 111 


\section{List of Tables}

Table 1. Average $\mathrm{pH}$, nitrate, and sulfate concentrations in precipitation in WV. NADP NTN Site WV04 (NADP, 2021a)

Table 2. Soil samples were extracted from O, A, and upper B Horizons at 10 site locations (see Figure 5 for site numbers) with and without liming treatment. Aspect and slope \% are also provided for each site.

Table 3. Average soil pH values in O, A, and B horizons for sites sampled in the Terrestrial Liming Project. See footnotes for explanations of statistical comparison among sites, within and across years, and with liming treatment. .33

Table 4. Average acidity values $\left(\mathrm{cmol}^{+} / \mathrm{kg}\right)$ in $\mathrm{O}, \mathrm{A}$, and $\mathrm{B}$ horizons for sites sampled in the Terrestrial Liming Project. See footnotes in Table 3 for letter and symbol descriptions .35

Table 5. Average ECEC values in $\mathrm{O}, \mathrm{A}$, and $\mathrm{B}$ horizons for sites sampled in the Terrestrial Liming Project. See footnotes in Table 3 for letter and symbol descriptions. 37

Table 6. Average \% OM values in O, A, and B horizons for sites sampled in the Terrestrial Liming Project. See footnotes in Table 3 for letter and symbol descriptions.

Table 7. Average \% TC values in O, A, and B horizons for sites sampled in the Terrestrial Liming Project. See footnotes in Table 3 for letter and symbol descriptions. .41

Table 8. Average \% TN values in O, A, and B horizons for sites sampled in the Terrestrial Liming Project. See footnotes in Table 3 for letter and symbol descriptions.

Table 9. Average $P$ values in $O, A$, and $B$ horizons for sites sampled in the Terrestrial Liming Project. See footnotes in Table 3 for letter and symbol descriptions.

Table 10. Average $\mathrm{K}$ values $\mathrm{O}, \mathrm{A}$, and $\mathrm{B}$ horizons for sites sampled in the Terrestrial Liming Project. See footnotes in Table 3 for letter and symbol descriptions.

Table 11. Average Ca values in O, A, and B horizons for sites sampled in the Terrestrial Liming Project. See footnotes in Table 3 for letter and symbol descriptions....

Table 12. Average Mg values in $\mathrm{O}, \mathrm{A}$, and $\mathrm{B}$ horizons for sites sampled in the Terrestrial Liming Project. See footnotes in Table 3 for letter and symbol descriptions.

Table 13. Average Na values in $\mathrm{O}, \mathrm{A}$, and $\mathrm{B}$ horizons for sites sampled in the Terrestrial Liming Project. See footnotes in Table 3 for letter and symbol descriptions.

Table 14. Average Al values O, A, and B horizons for sites sampled in the Terrestrial Liming Project. See footnotes in Table 3 for letter and symbol descriptions....

Table 15. Average Fe values in O, A, and B horizons for sites sampled in the Terrestrial Liming Project. See footnotes in Table 3 for letter and symbol descriptions.... 
Table 16. Average $\mathrm{Mn}$ values in $\mathrm{O}, \mathrm{A}$, and $\mathrm{B}$ horizons for sites sampled in the Terrestrial Liming Project. See footnotes in Table 3 for letter and symbol descriptions.

Table 17. Average $\mathrm{Zn}$ values in $\mathrm{O}, \mathrm{A}$, and $\mathrm{B}$ horizons for sites sampled in the Terrestrial Liming Project. See footnotes in Table 3 for letter and symbol descriptions.

Table 18. Average $\mathrm{pH}$ values for first-year results after liming for the Fowler et al. and Long et al. studies

Table 19. Average Ca concentrations $(\mathrm{cmol}+/ \mathrm{kg})$ for first-year results after liming for the Fowler et al. and Long et al. studies

Table 20. Average Al concentrations $(\mathrm{mg} / \mathrm{kg}$ ) for first-year results after liming for the Fowler et al. and Long et al. studies

Table 21. Average soil pH values in $\mathrm{O}$ horizons for sites sampled in the Terrestrial Liming Project. See footnotes for explanations of statistical comparison among sites, within and across years, and with liming treatment

Table 22. Average soil pH values in A horizons for sites sampled in the Terrestrial Liming Project. See footnotes in Table 21 for letter and symbol descriptions.... .80

Table 23. Average soil pH values in B horizons for sites sampled in the Terrestrial Liming Project. See footnotes in Table 21 for letter and symbol descriptions.

Table 24 . Average acidity values $(\mathrm{cmol}+/ \mathrm{kg})$ in $\mathrm{O}$ horizons for sites sampled in the Terrestrial Liming Project. See footnotes in Table 21 for letter and symbol descriptions.

Table 25. Average acidity values $(\mathrm{cmol}+/ \mathrm{kg}$ ) in A horizons for sites sampled in the Terrestrial Liming Project. See footnotes in Table 21 for letter and symbol descriptions.

Table 26. Average acidity values $(\mathrm{cmol}+/ \mathrm{kg}$ ) in B horizons for sites sampled in the Terrestrial Liming Project. See footnotes in Table 21 for letter and symbol descriptions.

Table 27. Average ECEC values ( $\mathrm{cmol}+/ \mathrm{kg}$ ) in O horizons for sites sampled in the Terrestrial Liming Project. See footnotes in Table 21 for letter and symbol descriptions

Table 28. Average ECEC values ( $\mathrm{cmol}+/ \mathrm{kg}$ ) in A horizons for sites sampled in the Terrestrial Liming Project. See footnotes in Table 21 for letter and symbol descriptions

Table 29. Average ECEC values ( $\mathrm{cmol}+/ \mathrm{kg}$ ) in B horizons for sites sampled in the Terrestrial Liming Project. See footnotes in Table 21 for letter and symbol descriptions... 
Table 30. Average \% OM values (\%) in O horizons for sites sampled in the Terrestrial Liming Project. See footnotes in Table 21 for letter and symbol descriptions.

Table 31. Average \% OM values (\%) in A horizons for sites sampled in the Terrestrial Liming Project. See footnotes in Table 21 for letter and symbol descriptions. 83

Table 32. Average \% OM values (\%) in B horizons for sites sampled in the Terrestrial Liming Project. See footnotes in Table 21 for letter and symbol descriptions. .83

Table 33. Average \% TC values (\%) in B horizons for sites sampled in the Terrestrial Liming Project. See footnotes in Table 21 for letter and symbol descriptions.

Table 34. Average \% TC values (\%) in B horizons for sites sampled in the Terrestrial Liming Project. See footnotes in Table 21 for letter and symbol descriptions.

Table 35. Average \% TC values (\%) in B horizons for sites sampled in the Terrestrial Liming Project. See footnotes in Table 21 for letter and symbol descriptions.

Table 36. Average \% TN values (\%) in O horizons for sites sampled in the Terrestrial Liming Project. See footnotes in Table 21 for letter and symbol descriptions.

Table 37. Average \% TN values (\%) in A horizons for sites sampled in the Terrestrial Liming Project. See footnotes in Table 21 for letter and symbol descriptions.

Table 38. Average \% TN values (\%) in B horizons for sites sampled in the Terrestrial Liming Project. See footnotes in Table 21 for letter and symbol descriptions.

Table 39. Average P values $(\mathrm{mg} / \mathrm{kg}$ ) in O horizons for sites sampled in the Terrestrial Liming Project. See footnotes in Table 21 for letter and symbol descriptions.....

Table 40. Average $P$ values $(\mathrm{mg} / \mathrm{kg}$ ) in A horizons for sites sampled in the Terrestrial Liming Project. See footnotes in Table 21 for letter and symbol descriptions.

Table 41. Average $P$ values $(\mathrm{mg} / \mathrm{kg}$ ) in B horizons for sites sampled in the Terrestrial Liming Project. See footnotes in Table 21 for letter and symbol descriptions.

Table 42. Average $\mathrm{K}$ values $(\mathrm{cmol}+\mathrm{kg})$ in $\mathrm{O}$ horizons for sites sampled in the Terrestrial Liming Project. See footnotes in Table 21 for letter and symbol descriptions.

Table 43. Average $\mathrm{K}$ values $(\mathrm{cmol}+\mathrm{kg})$ in A horizons for sites sampled in the Terrestrial Liming

Project. See footnotes in Table 21 for letter and symbol descriptions. .86

Table 44. Average $\mathrm{K}$ values $(\mathrm{cmol}+/ \mathrm{kg})$ in B horizons for sites sampled in the Terrestrial Liming Project. See footnotes in Table 21 for letter and symbol descriptions. 
Table 45. Average Ca values $(\mathrm{cmol}+/ \mathrm{kg})$ in O horizons for sites sampled in the Terrestrial Liming Project. See footnotes in Table 21 for letter and symbol descriptions.

Table 46. Average Ca values $(\mathrm{cmol}+/ \mathrm{kg})$ in A horizons for sites sampled in the Terrestrial Liming Project. See footnotes in Table 21 for letter and symbol descriptions.

Table 47. Average Ca values $(\mathrm{cmol}+/ \mathrm{kg})$ in B horizons for sites sampled in the Terrestrial Liming Project. See footnotes in Table 21 for letter and symbol descriptions....

Table 48. Average Mg values ( $\mathrm{cmol}+\mathrm{kg}$ ) in O horizons for sites sampled in the Terrestrial Liming Project. See footnotes in Table 21 for letter and symbol descriptions.

Table 49. Average $\mathrm{Mg}$ values $(\mathrm{cmol}+\mathrm{kg})$ in A horizons for sites sampled in the Terrestrial Liming Project. See footnotes in Table 21 for letter and symbol descriptions.

Table 50. Average $\mathrm{Mg}$ values $(\mathrm{cmol}+\mathrm{kg})$ in B horizons for sites sampled in the Terrestrial Liming Project. See footnotes in Table 21 for letter and symbol descriptions....

Table 51. Average Na values $(\mathrm{cmol}+/ \mathrm{kg})$ in O horizons for sites sampled in the Terrestrial Liming Project. See footnotes in Table 21 for letter and symbol descriptions. .89

Table 52. Average Na values $(\mathrm{cmol}+/ \mathrm{kg})$ in A horizons for sites sampled in the Terrestrial Liming Project. See footnotes in Table 21 for letter and symbol descriptions. .89

Table 53. Average Na values $(\mathrm{cmol}+/ \mathrm{kg})$ in B horizons for sites sampled in the Terrestrial Liming Project. See footnotes in Table 21 for letter and symbol descriptions.... .90

Table 54. Average Al values $(\mathrm{mg} / \mathrm{kg}$ ) in O horizons for sites sampled in the Terrestrial Liming Project. See footnotes in Table 21 for letter and symbol descriptions. .90

Table 55. Average Al values $(\mathrm{mg} / \mathrm{kg}$ ) in A horizons for sites sampled in the Terrestrial Liming Project. See footnotes in Table 21 for letter and symbol descriptions. .90

Table 56. Average Al values $(\mathrm{mg} / \mathrm{kg}$ ) in B horizons for sites sampled in the Terrestrial Liming Project. See footnotes in Table 21 for letter and symbol descriptions....

Table 57. Average Fe values $(\mathrm{mg} / \mathrm{kg}$ ) in O horizons for sites sampled in the Terrestrial Liming Project. See footnotes in Table 21 for letter and symbol descriptions.

Table 58. Average Fe values $(\mathrm{mg} / \mathrm{kg}$ ) in A horizons for sites sampled in the Terrestrial Liming Project. See footnotes in Table 21 for letter and symbol descriptions. 
Table 59. Average Fe values $(\mathrm{mg} / \mathrm{kg}$ ) in B horizons for sites sampled in the Terrestrial Liming Project. See footnotes in Table 21 for letter and symbol descriptions.

Table 60. Average $\mathrm{Mn}$ values $(\mathrm{mg} / \mathrm{kg}$ ) in O horizons for sites sampled in the Terrestrial Liming Project. See footnotes in Table 21 for letter and symbol descriptions.

Table 61. Average Mn values $(\mathrm{mg} / \mathrm{kg}$ ) in A horizons for sites sampled in the Terrestrial Liming Project. See footnotes in Table 21 for letter and symbol descriptions.

Table 62. Average Mn values $(\mathrm{mg} / \mathrm{kg}$ ) in B horizons for sites sampled in the Terrestrial Liming Project. See footnotes in Table 21 for letter and symbol descriptions....

Table 63. Average $\mathrm{Zn}$ values $(\mathrm{mg} / \mathrm{kg}$ ) in O horizons for sites sampled in the Terrestrial Liming Project. See footnotes in Table 21 for letter and symbol descriptions....

Table 64. Average $\mathrm{Zn}$ values $(\mathrm{mg} / \mathrm{kg}$ ) in A horizons for sites sampled in the Terrestrial Liming Project. See footnotes in Table 21 for letter and symbol descriptions.

Table 65. Average $\mathrm{Zn}$ values $(\mathrm{mg} / \mathrm{kg}$ ) in B horizons for sites sampled in the Terrestrial Liming Project. See footnotes in Table 21 for letter and symbol descriptions.

Table 66. Statistical codes for the analysis of this data 


\section{List of Figures}

Figure 1. Average $\mathrm{pH}$ in precipitation for 1985, 1995, 2005, and 2015. (NADP, 2021b)............10

Figure 2. Average nitrate in precipitation for 1985, 1995, 2005, and 2015. (NADP, 2021b).......11

Figure 3. Average sulfate in precipitation for 1985, 1995, 2005, and 2015. (NADP, 2021b).......12

Figure 4. Lower Williams Terrestrial Liming Project area is located in the Monongahela National

Forest, and the project area is located north of Richwood, WV ...............................................22

Figure 5. Areas that were limed during this project are shown in the cross-hatched areas and locations of sites and pits for both 2009 and 2019 sampling dates are shown...........................23

Figure 6. Map showing sampling locations from 2009 (red) and from 2019 (white) for sites 1, 3, and 16 on the northern extremity of the project area (see Figure 5 for relative location of these sites within the project area). 25

Figure 7. Map showing sampling locations from 2009 (red) and from 2019 (white) for sites E-

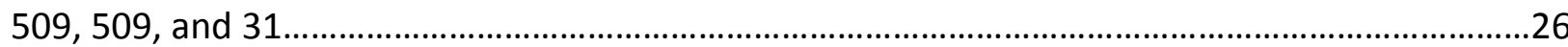

Figure 8. Map showing sampling locations from 2009 (red) and from 2019 (white) for sites 37, $37-2$, and $37-3$ .26

Figure 9. Map showing sampling locations from 2009 (red) and from 2019 (white) for site 18.

Figure 10. Data for each parameter were separated and analyzed based on horizon $(O, A, B)$, year of sampling (2009 vs 2019), liming treatment (UL vs L), and interactions. Interactions included sites within liming treatment within years (designated by 1 (purple) and 2 (red)), sites within liming treatment across years (designated by 3 (green) and 4 (blue)).....

Figure 11. Violin Plot of pH from both treatments in 2009 and 2019 showing the pH level differences between the years, treatments, and soil horizons as indicated in Table 3.

Figure 12. Violin plot of Acidity from both treatments in 2009 and 2019 showing the acidity $\left(\mathrm{cmol}^{+} / \mathrm{kg}\right)$ differences between years, treatments, and soil horizons as indicated in Table 4 (see description of violin plots in Figure 11).

Figure 13. Violin Plot of ECEC from both treatments in 2009 and 2019 showing the ECEC $(\mathrm{cmol}+/ \mathrm{kg})$ differences between the years, treatments, and soil horizons as indicated in Table 5 (see description in Figure 11).

Figure 14. Violin Plot of \% OM from both treatments in 2009 and 2019 showing the OM (\%) differences between the years, treatments, and soil horizons as indicated in Table 6 (see description in Figure 11). 
Figure 15. Violin Plot of \% TC from both treatments in 2009 and 2019 showing the TC (\%) differences between the years, treatments, and soil horizons as indicated in Table 7 (see description in Figure 11).

Figure 16. Violin Plot of \% TN from both treatments in 2009 and 2019 showing the TN (\%) differences between the years, treatments, and soil horizons as indicated in Table 8 (see description in Figure 11).

Figure 17. Violin Plot of $P$ from both treatments in 2009 and 2019 showing the $P(\mathrm{mg} / \mathrm{kg})$ differences between the years, treatments, and soil horizons as indicated in Table 9 (see description in Figure 11).

Figure 18. Violin Plot of $\mathrm{K}$ from both treatments in 2009 and 2019 showing the $\mathrm{K}(\mathrm{cmol}+\mathrm{kg})$ differences between the years, treatments, and soil horizons as indicated in Table 10 (see description in Figure 11).

Figure 19. Violin Plot of Ca from both treatments in 2009 and 2019 showing the $\mathrm{Ca}$ (cmol+/kg) differences between the years, treatments, and soil horizons as indicated in Table 11 (see description in Figure 11).

Figure 20. Violin Plot of Mg from both treatments in 2009 and 2019 showing the $\mathrm{Mg}(\mathrm{cmol}+/ \mathrm{kg})$ differences between the years, treatments, and soil horizons as indicated in Table 12 (see description in Figure 11).

Figure 21. Violin Plot of $\mathrm{Na}$ from both treatments in 2009 and 2019 showing the $\mathrm{Na}(\mathrm{cmol}+\mathrm{kg}$ ) differences between the years, treatments, and soil horizons as indicated in Table 13 (see description in Figure 11).

Figure 22. Violin Plot of Al from both treatments in 2009 and 2019 showing the $\mathrm{Al}(\mathrm{mg} / \mathrm{kg})$ differences between the years, treatments, and soil horizons as indicated in Table 14 (see description in Figure 11).

Figure 23. Violin Plot of Fe from both treatments in 2009 and 2019 showing the $\mathrm{Fe}(\mathrm{mg} / \mathrm{kg})$ differences between the years, treatments, and soil horizons as indicated in Table 15 (see description in Figure 11).

Figure 24. Violin Plot of Mn from both treatments in 2009 and 2019 showing the $\mathrm{Mn}(\mathrm{mg} / \mathrm{kg})$ differences between the years, treatments, and soil horizons as indicated in Table 16 (see description in Figure 811).

Figure 25. Violin Plot of Zn from both treatments in 2009 and 2019 showing the $\mathrm{Zn}$ (mg/kg) differences between the years, treatments, and soil horizons as indicated in Table 17 (see description in Figure 11). 
Figure 26. Soil sampling pit profile of Site 37 (Unlimed) (Pit \#5).................................................94

Figure 27. Soil sampling pit profile of Site 37-2 (Limed) (Pit \#3) ................................................95

Figure 28. Soil sampling pit profile of Site 37-3 (Limed) (Pit \#1) .................................................96

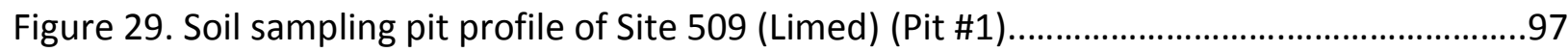

Figure 30. Soil sampling pit profile of Site E509 (Unlimed) (Pit \#5) ............................................98

Figure 31. Soil sampling pit profile of Site 31 (Unlimed) (Pit \#5)................................................99

Figure 32. Soil sampling pit profile of Site 1 (Unlimed) (Pit \#4)....................................................100

Figure 33. Soil sampling pit profile of Site 18 (Unlimed) (Pit \#3)................................................101

Figure 34. Soil sampling pit profile of Site 3 (Limed) (Pit \#1)...................................................102

Figure 35. Soil Sampling pit profile of Site 16 (Limed) (Pit \#2)..................................................103

Figure 36. Example of field notes from sampling. Site 37-2 (Page 1)........................................104

Figure 37. Example of field notes from sampling. Site 37-2 (Page 2)........................................105

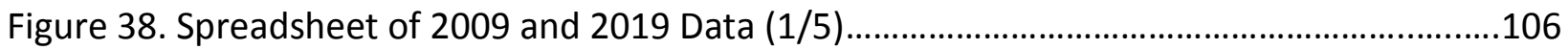

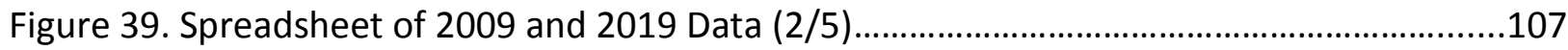

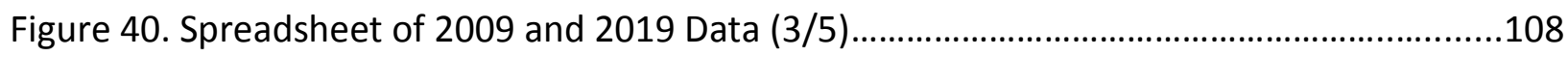

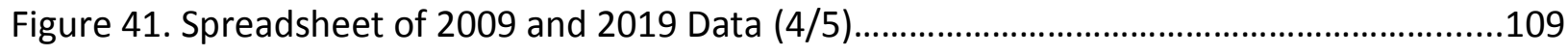

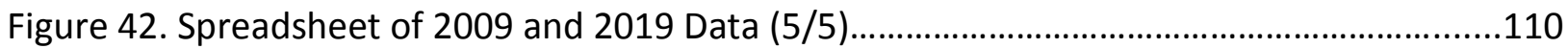




\section{Introduction}

Forest soils in the Appalachian region are becoming more acidic with time due to the uptake of base cations ( $\mathrm{Ca}, \mathrm{K}, \mathrm{Mg}$, and $\mathrm{Na}$ ) by vegetation, release of protons by vegetation, release of organic acids through organic matter decomposition, and acid deposition (Bailey et al., 2005; Drohan and Sharpe, 1997). Many of these forest soils are formed from acidic sandstone parent materials with no base-supplying capacity. Acid deposition exacerbates increasing acidity in these soils. Acid deposition is formed when sulfur oxides and nitrous oxides $\left(\mathrm{SO}_{\mathrm{x}}\right.$ and $\mathrm{NO}_{\mathrm{x}}$ ) from vehicles and industrial emissions are discharged into the atmosphere and then precipitate down as fine dust particles or with precipitation (Likens and Butler, 2019). The emissions react with atmospheric moisture to form sulfuric and nitric acids which fall on the landscape and infiltrate into soils (Shukla et al., 2013). The introduction of these products into soils results in an increase of soil acidity and decreasing soil pH (Kaupenjohann et al., 1989). These effects are most pronounced in forest soils with timber harvesting. When harvesting occurs, the removal of trees opens the forest up to invasion of tree and shrub species more adapted to acid conditions (often lower value tree species), thereby displacing the valuable hardwood forest that developed on the site during the past century with no acid deposition. This shift in composition of tree species due to acid deposition can lead to species losses, can impact forest diversity, and can decrease economic value of forests (Driscoll et al., 2001; Moore et al., 2014).

To mitigate acid deposition and decrease acidity of forest soils, liming is a recommended treatment (Moore et al., 2014; Huettl and Zoettl, 1993). Liming to reduce forest soil acidification has the potential to increase forest health and vitality, and to reduce the potential for forest composition change after harvesting. In studies where lime has been added to acid forest soils, results showed that indeed calcium (Ca) and magnesium ( $\mathrm{Mg}$ ) and soil pH increased and acidity decreased, and this improvement in soil chemistry due to liming appears to persist for years after liming (Bailey et al., 2005; Drohan and Sharpe, 1997).

The Monongahela National Forest (MNF) has one of the highest rates of acid deposition in the USA. As timber harvesting occurred in the forest, MNF soil scientists noticed changes in 
species composition and further study showed that soil pH declined (Connolly et al., 2007; Farr et al., 2009). Therefore, to mitigate these changes in soil acidity and forest composition, a liming program was developed by the US Forest Service (USFS), a division within the United States Department of Agriculture. Steep slopes, forest vegetation, and poor road networks make it difficult to apply lime to the surface by conventional surface liming application equipment. Therefore, application of lime by aerial methods using a helicopter was selected. Liming has been used before in Germany and other European countries to apply lime to acid soils since the mid 1980's (Huettl and Zoettl, 1993) and in North America for watershed improvement experiments (Driscoll et al., 1996; Battles et al. 2014; Johnson et al., 1997; Theenhaus and Schaefer, 1995), and for lake and stream remediation (Hudy et al., 2000; DEC, 2014).

\subsection{Study Objectives}

In 2018, 284 ha of land in the MNF were limed by helicopter aerial application. Based on previous studies in the Appalachian Region, a target liming rate of between 6.7 to $11.2 \mathrm{Mg} / \mathrm{ha}$ ( 3 to 5 tons/ac) was applied. A project was established between scientists with the USFS and West Virginia University (WVU) to sample soils in the MNF one, three, and five years after liming. The goal of the project was to determine whether an increase of $\mathrm{Ca}$ and a decrease in soil $\mathrm{pH}$ were realized in soils due to liming. Scientists sampled the soils by digging five soil pits at each of 10 locations representing both limed and unlimed areas. From each pit (50 total pits), a soil sample was taken from the $\mathrm{O}, \mathrm{A}$ and upper B horizons. Soil samples were analyzed for $\mathrm{Ca}$, $\mathrm{Mg}, \mathrm{pH}$, and acidity, along with other parameters by the University of Maine soil testing laboratory. The objectives of this study were to determine whether the expected changes due to liming were realized in the soils of the MNF. Specific questions were:

Did the application of lime to these soils:

1) raise $\mathrm{pH}$ and $\mathrm{Ca}$ levels in the $\mathrm{O}, \mathrm{A}$ and upper $\mathrm{B}$ horizons;

2) decrease soil acidity and Al concentrations in these horizons;

3) change other elemental concentrations in soils; 
4) and to determine the changes in these soils over the 10-year period from 2009 to 2019.

\section{Literature Review}

\subsection{Introduction}

Forest soils in the Appalachian region are becoming more acidic with the uptake of base cations ( $\mathrm{Ca}, \mathrm{K}, \mathrm{Mg}$, and $\mathrm{Na}$ ) by vegetation, release of protons by vegetation, release of organic acids through organic matter decomposition, and acid deposition (Bailey et al., 2005; Drohan and Sharpe, 1997). Acid deposition began as early as the 1950 's as coal-fired power plants were built to supply an expanding US economy dependent on electricity (Likens et al., 1996). Acid deposition (also known as acid rain) is formed when vehicular, industrial, and/or agricultural emissions of sulfur oxides and nitrous oxides $\left(\mathrm{SO}_{\mathrm{x}}\right.$ and $\left.\mathrm{NO}_{\mathrm{x}}\right)$ accumulate in the atmosphere and then precipitate down as fine dust particles or with precipitation (Likens and Butler, 2019). The emissions react with atmospheric moisture to form sulfuric and nitric acids which fall on the landscape and infiltrate into soils (Shukla et al., 2013). The introduction and accumulations of these acid products over time resulted in a change in soil chemistry, increasing soil acidity and decreasing soil pH (Kaupenjohann et al., 1989). Though most forest vegetation in this region is adapted to mildly acidic soil conditions, the decrease of soil pH from acid deposition, along with the uptake of base cations by vegetation, have exacerbated the impact thereby creating both environmental and economic problems (Burns et al., 2016; Burtraw et al., 2007, Federer et al., 1989). Acid deposition (acid rain) emerged as the most publicly visible environmental issue during the 1970's and 1980's and has been shown to have negative impacts on soils, soil fauna, forest tree species, amphibians, birds, aquatic biota, mammals, and humans (Greenfelt et al., 2020; Moore et al., 2014). A shift in composition of tree species due to acid deposition, which could lead to a loss of species associated with the dominant forest types, could impact forest diversity as well as economic value of forests (Driscoll et al., 2001; Moore et al., 2014).

These impacts are most often noticed on areas where timber harvesting has occurred because species more adapted to acid soil conditions replace those that existed before harvesting. The Monongahela National Forest (MNF) is composed of an assemblage of at least 
75 species of trees which are sorted across the landscape based on slope and aspect, soil depth and moisture, and disturbance (USDA Forest Service, 2020). White oak (Quercus alba), red oak (Quercus rubra), black oak (Quercus velutina), chestnut oak (Quercus prinus), tulip-poplar (Liriodendron tulipi fera), hickories (Carya spp.), black locust (Robinia pseudoacacia), and black cherry (Prunus serotina) are dominant species (Elias et al., 2009). With forest soils becoming more acid, red maple (Acer rubrum) and black cherry are increasing in the forest (Bigelow and Canham, 2002) with reductions in sugar maple (Acer saccharum), white oak and yellow poplar in forest stands (Moore et al., 2008; Moore and Quimet, 2006).

\subsection{Economic Value of Forests}

The forests in West Virginia provide significant income to the state. Being the third most forested state in the United States, the timber industry in West Virginia provides 30,000 jobs statewide and an annual income of $\$ 3$ billion (Snedegar, 2017). The wood produced from WV forests are more than 700 million board feet of lumber, 770 million square feet of oriented strand board (OSB), and 800 million square feet of veneer annually (Gazal et al., 2017). The forest-based industry in WV is separated into five categories: 1) miscellaneous forest products, 2) logging, 3) solid wood products, 4) wood furniture, and 5) pulp and paper (Gazal et al., 2017). The first category, miscellaneous forest products industry, consists of forest products and timber tract production, and contributes about 4,000 jobs, \$1.44 million in total labor income, $\$ 1.8$ million in total value added, and \$3.4 million in total output in 2015 . The logging industry, the second category, created 3,360 jobs and contributed \$105 million in total labor income, $\$ 129$ million in total value added, and \$237 million in total output; making it the second largest contributor to WV's economy out of the five forest-based industries in the state. The solid wood products industry category includes sawmills, wood preservation, veneer and plywood manufacturing, pre-fabricated wood buildings, wood container and pallet manufacturing, engineered wood members and truss manufacturing, reconstituted wood product manufacturing, and custom architectural woodwork and millwork manufacturing. In 2015, the solid wood product industry contributed 12,445 total jobs, \$535 million in total labor income, $\$ 771$ million in total value added, and $\$ 2.2$ billion in total output. Fourth, the wood furniture industry includes wood windows and doors and millwork manufacturing, wood kitchen cabinet 
and countertop manufacturing, upholstered and non-upholstered household wood furniture manufacturing, and office furniture. In 2015, this industry created about 2,189 jobs, and contributed \$95 million in labor income, \$105 million in total value added, and \$278 million in total output. The pulp and paper industry, the fifth category, includes, pulp, paper and paperboard mills, paperboard container manufacturing, coated and laminated paper, packaging paper and plastic films manufacturing, sanitary paper product manufacturing, and other converted paper product manufacturing. This industry provides 1,648 jobs, $\$ 87$ million in total labor income, \$135 million in total value added, and \$486 million in total output (Gazal et al., 2017).

Another important income-generator in West Virginia is the outdoor industry which includes tourism, hiking, fishing, whitewater rafting, canoeing, and hunting. According to the U.S. Fish and Wildlife Service, the hunting industry contributes \$552 million a year to WV, while skiing generates 250 million and whitewater rafting generates \$248 million (McCoy, 2018). Hunting in WV is also responsible for $\$ 153$ million in salaries and wages and \$35 million in state taxes (McCoy, 2018). Hunting related expenditures (lodging, food, transportation and equipment) also provided an additional income of $\$ 270$ million to West Virginia (WV DNR, 2020). According to the American Sportfishing Association (ASA) in 2018, it is estimated that 457,600 anglers spent $\$ 352$ million while fishing in West Virginia, contributed to the support of 4,950 jobs and resulted in \$518 million in economic output (American Sportfishing Association, 2019). License sales also provide a source of revenue for the state. For the 2018-2019 fiscal year, the total revenue from hunting and fishing license sales was $\$ 14$ million (\$8 million from 582,280 resident license sales and \$6 million from 220,437 nonresident license sales) (WV DNR, 2019). West Virginia state parks and forests provided recreation for nearly 7 million visitors and employed 400 full time workers and 1,200 seasonal and summer staff directly in fiscal year 2016-2017. This section also provided jobs for an additional 3,209 full-time equivalent jobs in support industries. The economic impact of West Virginia state parks and forests annually ranges from $\$ 161$ million to $\$ 190$ million (WV DNR, 2019).

With diminished forest quality and water quality due to increasing acidic soils, the economic impact on the timber industry and on outdoor recreation activities could be 
devastating on West Virginia and the states in the Appalachian region both short-term and long-term. A long-term effect is the replacement of oaks by maples, although this change is not yet obvious in mast production but will take decades to reverse (McShea et al., 2007). This decline of an important tree species will accompany loss of wildlife habitat and ecosystem function as acorns are the most important food resource for birds and mammals during the dormant season in hardwood ecosystems. Acorn abundance levels can affect many bird and mammal species in regard to the length of their home ranges, reproduction during the winter, feeding habits, body fat percentage, and can affect milk fat percentage (McShea et al., 2007).

\subsection{Geology and Soils}

West Virginia, as well as throughout the Appalachian region, has both a mixture of naturally acidic soils and calcareous soils. Soils of the Eastern Allegheny Plateau and Mountains area were formed in acid sandstone, shale and siltstone. They are medium-textured and have low pH and fertility (Sencindiver, 2010). Soils are often shallow, shaley, droughty, and not highly productive with moderate to severe erosion potential (Connolly et al., 2007). Forest soils in the Appalachian region are moderately acidic that have a common $\mathrm{pH}$ range of 4.5-6.5 (Zipper et al., 2013; Simmons et al., 2008; Cotton., 2006). Forest soils in the Appalachian region also show a range of $28 \%$ to $53 \%$ OM in the O horizon layers (Garten Jr et al., 1999).

The parent material of the Lower Williams Watershed in the MNF is from the Pottsville formation. The Pottsville formation is found within the Kanawha and New River geologic groups

from the Pennsylvanian Period of the Paleozoic Era and is known to be naturally base-poor (Farr et al., 2009). This formation is composed of $60-70 \%$ sandstone and $25-30 \%$ shale, with smaller amounts of coal and limestone (Farr et al., 2009). Being base-poor, the Pottsville formation as parent material for soils results in extremely low base cation levels, low effective cation exchange capacity, high concentrations of Al and Fe (Johnson, 2002) with pH values ranging from 3.5 to 4.6 (Connolly et al., 2007). For example, in 2004, Farr et al. (2009) found soils in the Cherry River watershed to have Ca concentrations range from 0.1 to $0.8 \mathrm{cmol}+/ \mathrm{kg}, \mathrm{Mg}$ concentrations from 0.05 to $0.31 \mathrm{cmol} / / \mathrm{kg}$, and Al concentrations from 2.8 to $7.2 \mathrm{cmol}+\mathrm{kg}$. 
Farr et al. (2009) also found that the soils in the Cherry River watershed had soil pH from 3.7 to 4.6, acidity from 3.3 to $9.4 \mathrm{cmol}+/ \mathrm{kg}$, ECEC from 3.6 to $10.7 \mathrm{cmol}+\mathrm{kg}$, and \% C from 0.3 to $8.1 \%$.

\subsection{Coal Combustion and Acid Deposition}

Coal is an important resource for industrial use and energy production, although its use particularly as an energy source for electrical power generation has declined during the past decade (USEIA, 2019). Since the 1900's and especially after World War II, the demand and dependency for coal significantly increased in order to provide the industrial and energy demands throughout the United States. Coal burning power plants produced more than half of the electricity generated in the United States during the mid to end of the $20^{\text {th }}$ Century (Yeager and Baruch, 1987; USEIA, 2019). The type of coal burned to meet these electrical-generation demands was bituminous coal (called steam coal) because of the high amount of energy released from its combustion. However, much of the coal burned had high sulfur contents. Unfortunately, the high sulfur contents in these coals when burned released emissions of sulfur oxides into the atmosphere (Yeager and Baruch, 1987). Other gases released from coal combustion include water $\left(\mathrm{H}_{2} \mathrm{O}\right)$, carbon dioxide $\left(\mathrm{CO}_{2}\right)$, nitrous oxides $\left(\mathrm{NO}_{\mathrm{x}}\right)$, and particulate matter (PM). As these compounds were released into the atmosphere, the $\mathrm{SO}_{\mathrm{x}}$ and $\mathrm{NO}_{\mathrm{x}}$ combined with atmospheric moisture to form sulfuric and nitric acids and either attached to dust particles and fell to the ground or fell to the earth with precipitation (acid rain). Over the 10-year period from 1985 to 1995, the $\mathrm{pH}$ of precipitation was about 4.4, and about $20 \mathrm{~kg} / \mathrm{ha}$ of sulfate and $12 \mathrm{~kg} / \mathrm{ha}$ of nitrate were deposited each year in the Allegheny Plateau Region of West Virginia due to acid precipitation (National Atmospheric Deposition Program, 2020). These values have been reduced substantially after enactment of the Clean Air Acts.

\subsection{Clean Air Acts}

During the 1960's, environmental regulations and control began to develop. Each pollution type (air, water, solid waste) and discipline had its own pollution history and sources, pollutant types, unique constituency, and its own regulatory framework (Yeager and Baruch, 1987). The relationships among the disciplines were viewed narrowly from a social or ecosystem health or nuisance perspective and regulatory interpretations were largely 
uncoordinated state or local matters (Yeager and Baruch, 1987; Greenstone, 2004). During the 1960's, the federal government established the Environmental Protection Agency (EPA) and water and air pollution standards were established. Air emission limits were regulated with the Clean Air Act (CAA) in 1970 (Greenstone, 2004). The CAA gave the EPA enforcement authority for environmental pollution (Holst, 2020). The CAA was later expanded from its original guidelines to establish a national regulatory program, with specific air quality requirements, federal enforcement, and federally-issued permits; this required large industrial companies to address and control their contributions to air pollution (Holst, 2020). The National Ambient Air Quality Standards (NAAQS) were authorized by the CAA of 1970 and addressed six pollutants that threatened public health (USEPA, 2019). These pollutants were sulfur dioxide, nitrogen dioxide, particulate matter, carbon monoxide, ozone, and lead. States and industry in the US were required to meet the levels established by the NAAQS or else face substantial "nonattainment" fines and penalties (Holst, 2020).

The CAA of 1970 was amended with stronger restrictions reducing many $\mathrm{SO}_{\mathrm{x}}$ and $\mathrm{NO}_{\mathrm{x}}$ emissions (Cavender et al., 1973). Many of these emissions were primarily from vehicular, industrial, and agriculture-related emissions. Anthropogenic emissions of sulfur dioxide in the eastern US were primarily released from coal-fired power plants, while anthropogenic emission of nitrogen oxides were largely attributed to motor vehicles and land-based sources (Civerolo et al., 2001). The CAA and its subsequent amendments helped reduce large amounts of $\mathrm{SO}_{\mathrm{x}}$ and $\mathrm{NO}_{\mathrm{x}}$ emissions from being released into the environment and the CAA Amendments of 1990 led to increased authority by EPA and included major reductions of $\mathrm{SO}_{2}$ emissions. From 1970 to 1990, $\mathrm{SO}_{2}$ emissions declined from $0.0301 \mathrm{ppm}$ to $0.0048 \mathrm{ppm}$ (85\%) (Greenstone, 2004). Between 1990 and 2017, the CAA of 1990 put in place emission limits that helped cut an additional $88 \%$ of $\mathrm{SO}_{2}$ emissions (USEPA, 2020; National Geographic, 2018). The CAA, with the requirements from the NAAQS, dropped the six listed pollutants by $63 \%$ in the US from 1980 to 2015 (USEPA, 2020). The reductions in emissions from industries due to enforcement of the CAA have had a positive change in WV precipitation. Rainfall $\mathrm{pH}$ levels have increased over time from an average of 4.3 in 1985 to an average of 5.0 in 2015 (Table 1) (NADP, 2021a) (Figure 1, Figure 4) (NADP, 2021b). Average concentrations of nitrate and sulfate in precipitation have 
also been reduced from averages of $1.3(\mathrm{mg} / \mathrm{L})$ and $2.2(\mathrm{mg} / \mathrm{L})$ in 1985 to $0.6(\mathrm{mg} / \mathrm{L})$ for nitrate and 0.5 (mg/L) for sulfate in 2015 (Table 1) (NADP, 2021a) (Figure 5, Figure 8, Figure 9, Figure 12) (NADP, 2021b).

Table 1. Average $\mathrm{pH}$, nitrate, and sulfate concentrations in precipitation in WV. NADP NTN Site WV04 (NADP, 2021a.)

\begin{tabular}{|c|c|c|c|c|}
\hline Year & $\mathrm{pH}$ & Nitrate $(\mathrm{mg} / \mathrm{L})$ & Sulfate $(\mathrm{mg} / \mathrm{L})$ & Conductivity \\
\hline 1985 & 4.3 & 1.3 & 2.2 & 24.8 \\
\hline 1995 & 4.5 & 1.2 & 1.4 & 17.5 \\
\hline 2005 & 4.5 & 1.1 & 1.8 & 19.4 \\
\hline 2015 & 5.0 & 0.6 & 0.5 & 6.5 \\
\hline
\end{tabular}



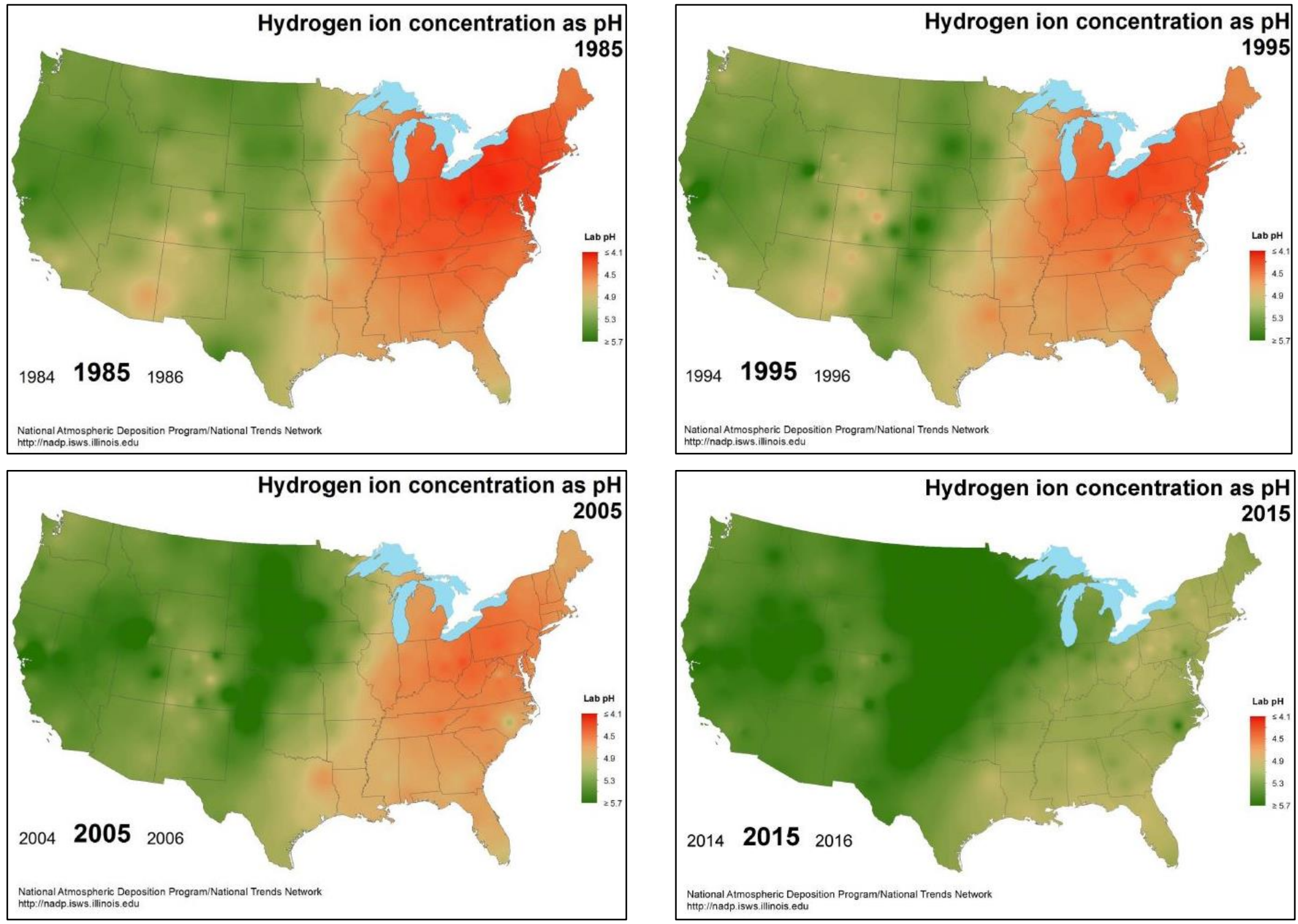

Figure 1. Average $\mathrm{pH}$ in precipitation for 1985, 1995, 2005, and 2015. (NADP, 2021b). 

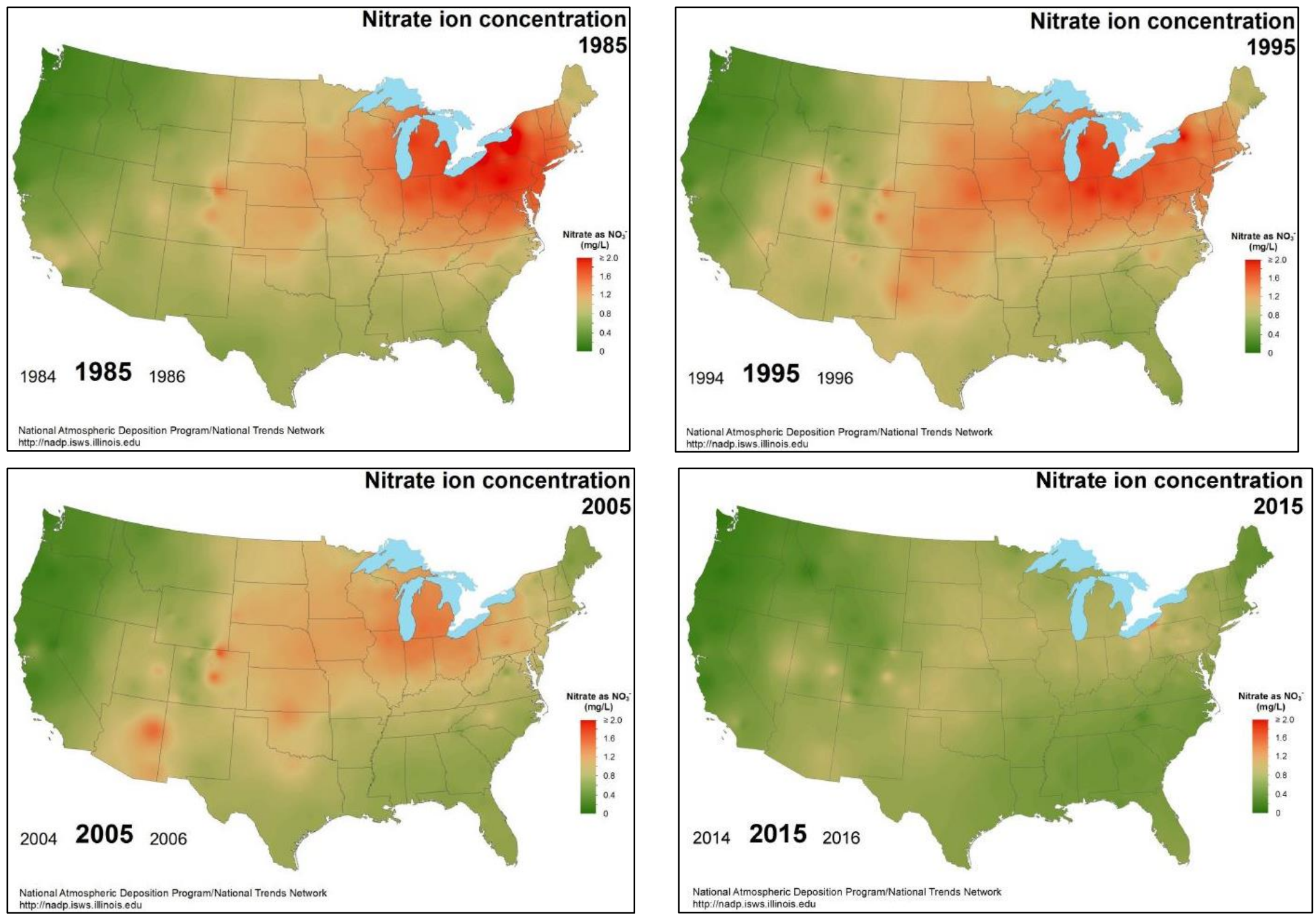

Figure 2. Average nitrate in precipitation for 1985, 1995, 2005, and 2015. (NADP, 2021b). 

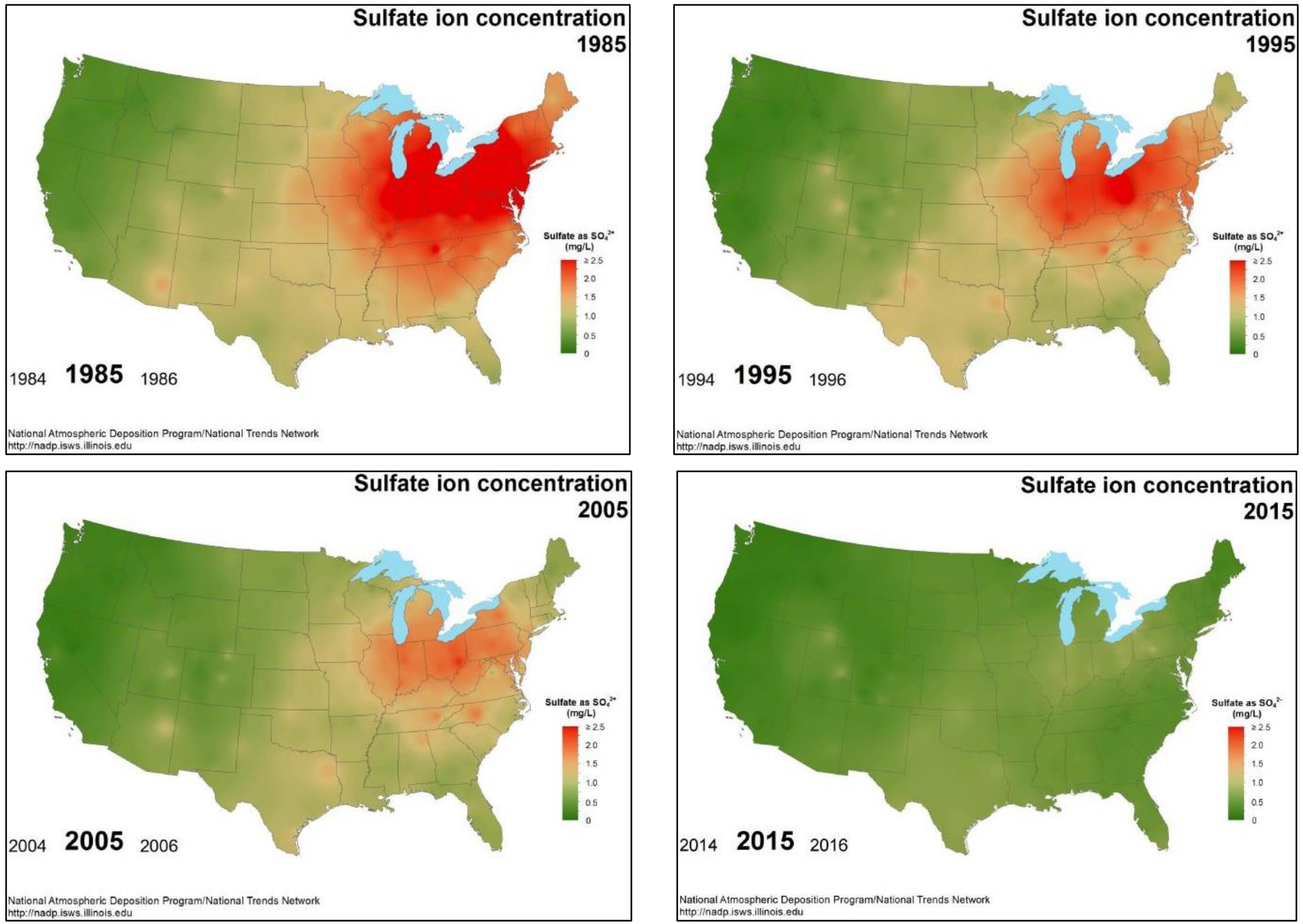

Figure 3. Average sulfate in precipitation for 1985, 1995, 2005, and 2015. (NADP, 2021b). 


\subsection{Changes in Soil Acidity}

A number of studies have documented changes in soil acidity in Appalachian forest soils due to acid deposition. According to the long-term mass balance model for the Hubbard Brooke Experimental Forest, most of the depletion of soil Ca occurred during the 1970's (Likens et al., 1996; Bailey et al., 2003) coinciding with minimal or emerging air-quality emission regulations. In 1967, soils representing the dominant soil series and land uses (agriculture and forestry) from 14 sites (six forested, eight agricultural) in northeastern Pennsylvania were investigated by researchers at Pennsylvania State University (Bailey et al.,2005). In 1997, four of the forested sites were resampled from the 1967 survey using the same sampling techniques and analyzed using similar chemical techniques as in the 1967 study. At most sites, $\mathrm{pH}$ and exchangeable Ca and $\mathrm{Mg}$ concentrations were lower, while exchangeable Al concentrations were higher in the Oa/A horizons from the samples collected in 1997 compared to those sampled in 1967 (Bailey et al., 2005). The average $\mathrm{pH}$ of the $\mathrm{Oa} / \mathrm{A}$ horizon dropped by 0.9 units over the 30 -year period (Bailey et al., 2005). Exchangeable $\mathrm{Ca}$ and $\mathrm{Mg}$ were more than four and two times lower, respectively, and exchangeable Al was 1.8 times higher in 1997 than in 1967 (Bailey et al., 2005). The combined loss in exchangeable $\mathrm{Ca}$ and $\mathrm{Mg}$ in the $\mathrm{Oa} / \mathrm{A}$ horizon over the 30-year period was $4.1 \mathrm{cmol}_{\mathrm{c}} / \mathrm{kg}$ compared with a gain of $2.6 \mathrm{cmol} / \mathrm{kg}$ of Al; this difference was associated with an increase of exchangeable $\mathrm{H}$, which would be consistent with the observed drop in $\mathrm{pH}$, or with a reduction in cation exchange capacity (CEC) (Bailey et al., 2005). In B horizons, exchangeable Ca and Mg were 10 times lower in 1997 than in 1967 (Bailey et al., 2005).

In 1993, 11 undisturbed forested sites were selected in Pennsylvania to measure whether forest soils had become more acidic (Drohan and Sharpe, 1997). Soil chemistry data were obtained from four previous studies conducted between 1957 and 1979 (Aguilar, 1981; Craul, 1964; Engle, 1964; and Steputis, 1963). Chemical analysis methods were evaluated to ensure that the methods used in 1993 were comparable to those of the original studies. The mean $\mathrm{pH}$ in both the $\mathrm{O}$ and $\mathrm{A}$ horizons was reduced at all nine sites from previously available 
data, although slight increases in pH occurred in the A horizon at two sites in 1993 (Drohan and Sharpe, 1997). Ca concentrations in the O horizon were lower at all but one of the sites and six out of 11 sites had lower Ca concentrations in at least the uppermost part of the A horizon in 1993. Mean $\mathrm{pH}$ was significantly reduced by $0.78 \mathrm{pH}$ units in the $\mathrm{O}$ horizon and by $0.23 \mathrm{pH}$ units in the A horizon of the sites sampled in 1993 compared to 1957-1961. Aluminum increased in the $\mathrm{O}$ horizon at two of the six measured sites and increased in the A horizon at four of the six sites. Overall, soils at the sampling sites had clearly become more acidic since the initial sampling, which varied from 8-15 years between studies, and this acidification was due to forest uptake of base cations and leaching related to acidic deposition (Drohan and Sharpe, 1997).

Between 1967 and 1999, Bailey et al. (2005) found forest soils in the Allegheny National Forest in northeastern Pennsylvania decreased in $\mathrm{pH}$ and exchangeable $\mathrm{Ca}$ and $\mathrm{Mg}$ and increased in exchangeable Al over those 30 years. Similarly, Markewitz et al. (1998) reported that the A horizons in the Calhoun Experimental Forest in South Carolina showed accelerated acidification due to acid deposition from 1962 to 1990. In England, Blake et al. (1999) determined from a 100-yr study that acid deposition was the major cause of soil acidification in the Geescroft Wilderness Area. Evidence of acidification included declines in surface soil pH of approximately 2.5 units since 1883 and lesser decreases in $\mathrm{pH}$ in subsurface layers. In the adjacent Broadbalk Wilderness that was heavily limed with $\mathrm{CaCO}_{3}$, no changes in $\mathrm{pH}$ were noted (Blake et al., 1999). Exchangeable Ca found in the surface layers dramatically decreased $86 \%$, from $14.1 \mathrm{cmol}+/ \mathrm{kg}$ in 1881 to $2.1 \mathrm{cmol}+/ \mathrm{kg}$ in 1991 (Blake et al., 1999). There was also a significant increase of Al in the Geescroft Wilderness as Al levels increased approximately 35 times between 1904 and 1964 (4 mg/kg to $135 \mathrm{mg} / \mathrm{kg}$ ) and by another three times from 1964 to 1991 (135 mg/kg to $410 \mathrm{mg} / \mathrm{kg}$ ) in the surface layers (Blake et al., 1999). Blake et al. (1999) also showed in the Geescroft Wilderness that the CEC of the surface layers decreased by $47 \%$ since 1881 , while the subsurface layers decreased by only $27 \%$ by 1991 . In South Korea, acidification of soils due to acid deposition reduced uptake of nutrients for Pinus thunbergii and that $\mathrm{Mg}$ deficiency and $\mathrm{Al}$ and $\mathrm{Mn}$ in soil solution limited tree growth (Yang et al. 2009). Other 
studies from the US, Europe, and Asia have shown similar acidification trends in soils from acid deposition (Krug and Frink, 2010; Larssen et al., 2000; Menz and Seip, 2004)

As $\mathrm{pH}$ declines and acidity increases in soils, metals such as $\mathrm{Al}$ and micronutrients such as $\mathrm{Cu}, \mathrm{Ni}$, and $\mathrm{Zn}$ will leach from the soils and into streams and water ways (Driscoll et al., 2003; Stevens et al., 2009). This will harm water quality not only for human use, but for wildlife (Schreiber and Newton, 1988), and most importantly for aquatic life (Driscoll et al., 2001). For example, Driscoll et al. (2001) found that an increase in Al concentrations in water resulted in reduced species richness and abundance of zooplankton, macroinvertebrates, and fish. Gallagher and Baker (1990) surveyed 1469 lakes in the Adirondack Mountains of New York and found that 346 lakes (24\%) had no fish caught. These 346 lakes had significantly lower pH levels and lower Ca concentrations, as well as higher concentrations of Al, when compared to lakes where fish were caught. Driscoll et al. (2001) also found that the data recorded by Gallagher and Baker (1990) showed that lakes with lower $\mathrm{pH}$ levels also had lower fish species diversity and numbers. For example, seven lakes with water $\mathrm{pH}$ of 4.0-4.5 had a mean of 1 fish species caught, 92 lakes with $\mathrm{pH}$ of 4.51-5.0 had a mean less than 2 fish species, 118 lakes with $\mathrm{pH}$ of 5.01-5.5 had a mean of 3 fish species, 110 lakes with a pH of 5.51-6.0 had a mean of 4 fish species, and 154 lakes with a pH of 6.1-6.5 had a mean of 5 fish species. These lower $\mathrm{pH}$ values, especially below 5.0, decreased fish species richness as the acid-sensitive species were eliminated (Driscoll et al., 2001). Of the 53 species of fish recorded in Gallagher and Baker's study (Kretser et al., 1989), about half of the species were absent from lakes that had a $\mathrm{pH}$ less than 6.0, which included important recreational fish species such as Atlantic salmon (Salmo salar), tiger trout (Salmo trutta $\times$ Salvelinus fontinalis), redbreast sunfish (Lepomis auratus), bluegill (Lepomis macrochirus), tiger musky (Esox masquinongy x Esox Lucius), walleye (Sander vitreus), alewife (Alosa pseudoharengus), and kokanee salmon (Oncorhynchus nerka); as well as ecologically important minnows that are forage for sport fish. Fish species that were more commonly caught (brown bullhead (Ameiurus nebulosus), yellow perch (Perca flavescens), golden shiner (Notemigonus crysoleucas), brook trout (Salvelinus fontinalis), and white sucker (Catostomus commersonii)) showed the greatest 
tolerance of the acidic conditions as their occurrence was in lakes that had relatively low $\mathrm{pH}$ and high Al concentrations (Gallagher and Baker, 1990).

The Ca/Al molar ratio of forest soils can be used to indicate declines in tree growth in acid soils (Cronan and Grigal, 1995; Lyon and Sharpe, 1999). In a study of forest soils in the MNF (near to the sites sampled in this liming study), Farr et al. (2009) found that 50 to $75 \%$ of soils sampled in the forest had a low $\mathrm{Ca} / \mathrm{Al}$ ratio which translated into a high degree of risk for forest regeneration and tree growth after conventional tree harvesting. They proposed that mitigation techniques such as liming be used to improve the $\mathrm{Ca} / \mathrm{Al}$ ratio in the soil before timber harvesting, or to exclude from timber harvesting those areas with the lowest $\mathrm{Ca} / \mathrm{Al}$ ratios and therefore highest risk for forest regeneration.

\subsection{Mitigation of Soil Acidity in Forest Systems}

Forest ecosystems affected by acid deposition have been slow to recover even with the decrease in acid deposition rates during the past 20 years (Nierzwicki-Bauer et al., 2010; Lawrence et al., 2012), and some of these affected areas will never recover unless further measures are taken to combat and mitigate acid deposition (Harald et al., 2005).

Decades of acid deposition have acidified forest soils and freshwaters throughout the world and have stripped base cations from soils thereby limiting rates of forest growth. As gases responsible for acid deposition have declined from emission-polluting industries through enforcement of the CAA, inputs of sulfuric and nitric acid to soils have been slowed. Recent studies have shown a slight but measurable recovery of soils resulting from lower emissions. For example, Lawrence et al. (2015) resampled 27 forest soil sites in eastern Canada and northeastern USA with reductions in acid deposition and found small increases in $\mathrm{pH}$ in $\mathrm{O}$ horizons and decreases in exchangeable Al (see also Lawrence et al., 2012 and Berger et al., 2016). But not all forest soils in the northeast have shown improvements (Connolly et al., 2007; Farr et al., 2009). 
To mitigate acid deposition and acidity of soils, liming is the recommended treatment (Moore et al., 2014; Huettl and Zoettl, 1993). Liming to reduce forest soil acidification has the potential to increase forest health and vitality. Liming forested and aquatic systems is a fairly new practice starting in the mid-1980s (Westling and Hultberg, 1990), although liming agricultural soils has been practiced for centuries (Adams, 1984). Forest liming is being used on a commercial scale in central Europe to treat forests that are suffering from nutrient imbalances and soil acidification, and extensive forest liming programs are underway in southern Sweden (Derome et al., 2000), the Czech Republic (Formanek and Vranova, 2003) and Germany (Jansone et al., 2020).

Liming forest soils has become an interest with the finding that Ca concentrations in mineral soils are associated with forest soil fertility and tree growth. Calcium application was included as one of the treatments in a long-term fertilization experiment by the Finnish Forest Research Institute at the beginning of the 1960's (Derome et al., 2000). Even a small amount of finely ground limestone applied at $2 \mathrm{Mg} / \mathrm{ha}$ (0.9 tons/ac) had a long-term, decreasing effect on soil acidity. Twenty years after liming, the $\mathrm{pH}$ of the organic and uppermost mineral layer on the limed plots was around $0.5 \mathrm{pH}$ units higher than the control plots (Derome et al., 2000). Liming increased base saturation for both the organic and mineral soil layers and after 20 years these layers were still almost double that of control plots. The increased concentration of $\mathrm{Ca}^{2+}$ and $\mathrm{Mg}^{2+}$ ions in the soil resulted in the displacement of $\mathrm{H}^{+}$and $\mathrm{Al}^{3+}$ ions from cation exchange sites. Exchangeable Al in both the organic and mineral soil layers was significantly decreased but liming also increased nitrogen mineralization as a result of the increase in $\mathrm{pH}$ which resulted in a risk of nitrate leaching (Derome et al., 2000). Similarly, Pabian et al. (2012a, b) found liming to increase $\mathrm{Ca}$ and $\mathrm{Mg}$ concentrations with concurrent reductions in $\mathrm{Al}$ and $\mathrm{Mn}$ concentrations, which continued five years after liming, and these were reflected in plant tissue concentrations growing on the site. Schaff and Huettl (2006) reviewed a number of liming studies in Europe and concluded that liming effects can be quite variable based on lime form and particle size, liming frequency and rates, soil types and nutrient status, site history and management. They encouraged the use of element budgets as tools to determine forest liming and fertilization effects over time. 
Though there are limited long-term studies in the US, those studies have shown that liming has increased $\mathrm{pH}$, increased base cations $(\mathrm{Ca}, \mathrm{Mg})$, decreased exchangeable acidity in the upper soil horizons, and decreased the concentrations of potentially toxic elements such as Al and $\mathrm{Mn}$. For example, Long et al. (2015) in northern Pennsylvania applied pulverized dolomitic limestone (21\% Ca and $12 \% \mathrm{Mg}$ ) to plots at a rate of $22 \mathrm{Mg} / \mathrm{ha}$ (10 tons/ac). They found increases in exchangeable $\mathrm{Ca}$ and $\mathrm{Mg}$ and $\mathrm{pH}$ in forest soils 21 years post-treatment. Exchangeable $\mathrm{Mn}$ and Al concentrations were significantly reduced. These changes in soils were also reflected in foliage nutrient concentrations in sugar maple (Acer saccharum). Sugar maple leaves in unlimed areas had Ca concentrations of $19.1 \mathrm{mg} / \mathrm{g}$ while those in limed areas had 21.6 $\mathrm{mg} / \mathrm{g}$ (Burke and Raynal, 1998). Concentrations of Mg in sugar maple leaves in the unlimed areas were $2.5 \mathrm{mg} / \mathrm{g}$ vs $2.9 \mathrm{mg} / \mathrm{g}$ in limed areas. Similar results were found for K (4.9 vs 6.0 $\mathrm{mg} / \mathrm{g}$ ), P (1.4 vs $2.0 \mathrm{mg} / \mathrm{g}$ ), and N (22.2 vs $23.1 \mathrm{mg} / \mathrm{g}$ ) (Burke and Raynal, 1998). Limed forest watersheds had reduced leaching of Al from soils into streams and stream water had increased acid buffering capacity (Moore et al., 2014). Moore et al. (2014) noted that forb ground cover increased three years after liming and that the forest floor of a mixed hardwood forest doubled the carbon reservoir 19 years post liming treatment.

Liming rates and the type of liming material are importance factors when liming acid soils and the eventual effect on the ecosystem. High liming rates (10-50 Mg/ha or 4.5-22 tons/ac) were noticed to have decreased N, P, and K in soils. This may be due to higher liming rates increasing the $\mathrm{pH}$ and reducing $\mathrm{Fe}$ and $\mathrm{Al}$ so that microbial populations flourished and plant uptake of these important macronutrients increased. However, low liming rates (0.5-5 $\mathrm{Mg} / \mathrm{ha}$ or 0.2 to 2 tons/ac) did not lead to a decrease of these element concentrations in the soil nor foliage (Moore et al., 2014) probably due to the reduced stimulation of microbial activity and plant growth. Having a liming rate of 6.7 to $11.2 \mathrm{Mg} / \mathrm{ha}$ (3 to 5 tons/ac) may be sufficient for restoring nutritional status of acid soils depending on the initial nutrient status before liming (Moore et al., 2014) without causing a reduction in N, P, and $\mathrm{K}$.

A review of the effectiveness of liming on fish populations in acidified streams showed increased fish abundance and increases in macroinvertebrates (Hindar et al., 1995; Hudy et al., 
2000; Mant et al., 2013). Newton et al. (1996) found increases in lake acid-neutralizing capacity primarily due to increases in Ca concentrations in limed watersheds in the Adirondacks.

One of the negative effects of liming acid forest soils is the export of $\mathrm{H}^{+}$and $\mathrm{Al}^{3+}$ from soils into nearby streams. Liming rates of 5 to $7 \mathrm{Mg} / \mathrm{ha}$ of $\mathrm{CaCO}_{3}$ (2 to 3 tons/ac) were found to increase the levels of dissolved organic carbon and dissolved organic nitrogen in soils due to the enhanced microbial activity with higher pH (Andersson et al., 1999; Driscoll et al., 1996; Moore et al., 2014). Rosi-Marshall et al. (2016) explained that limed forested watersheds can become net exporters of nitrogen because of microbial stimulation and nitrogen mineralization thereby causing unforeseen consequences in downstream lakes and rivers.

\subsection{The Monongahela National Forest}

The Monongahela National Forest (MNF) lies at the confluence of the mixed mesophytic and oak-chestnut forest regions, with remnants of northern hardwoods at high elevations (USDA Forest Service, 2011). With the loss of the American chestnut (Castanea dentata) and removal of virgin timber at the turn of the 19th and 20th centuries, the MNF has been dominated by white oak (Quercus alba), Northern red oak (Quercus rubra), chestnut oak (Quercus prinus), tulip-poplar (Liriodendron tulipi fera), black oak (Quercus velutina), hickories (Carya spp.), blackgum (Nyssa sylvatia), and black locust (Robinia pseudoacacia) (Thomas-Van Gundy and Strager, 2011). The species composition above $1000 \mathrm{~m}$ is dominated by red spruce (Picea rubens), sugar maple, American beech (Fagus grandifolia), American basswood (Tilia americana), and yellow birch (Betula alleghaniensis). The historical average annual productivity of these second- and third-growth forests was around $2 \mathrm{~m}^{3} /$ ha on poor sites, and over $7 \mathrm{~m}^{3} /$ ha on excellent sites (Elias et al., 2009). Periodic mean annual volume increment (PMAVI) ranged from 1.8 to $2.4 \mathrm{~m}^{3} / \mathrm{ha} / \mathrm{yr}$ on poor and fair sites, 3.0 to $3.6 \mathrm{~m}^{3} / \mathrm{ha} / \mathrm{yr}$ on average to good sites, and over $4.3 \mathrm{~m}^{3} / \mathrm{ha} / \mathrm{yr}$ on rich sites (Schnur, 1937). Stand disturbances, such as management practices, can influence and increase average annual growth rates; an example is that the growth rates five years after thinning of 65-year-old hardwood plots in West Virginia were greater than $5 \mathrm{~m}^{3} / \mathrm{ha} / \mathrm{yr}$ and can be used as a baseline to compare current measurements (Smith et al., 1994). 
The MNF is downwind from sulfate and nitrate pollutant sources. In 2007, measurements from various weather stations across the forest averaged wet $\mathrm{SO}_{4}{ }^{2-}$ deposition around $8 \mathrm{~kg} / \mathrm{ha}$, wet $\mathrm{NO}_{3}$ deposition around $3 \mathrm{~kg} / \mathrm{ha}$, and precipitation $\mathrm{pH}$ around 4.4 (National Atmospheric Deposition Program, 2020). Evidence for forest decline in the MNF is due, in part, to acid deposition, and has been reported for some species in some areas. Red spruce, sugar maple, and northern red oak suffer from both direct effects of acid deposition, such as nutrient leaching from needles, and from indirect effects such as decreased $\mathrm{pH}$ and elevated $\mathrm{Al}$ levels in soils (Bailey et al., 2005; Demchik and Sharpe, 2000; Godbold and Huttermann, 1988; Johnson and Siccama, 1983).

\subsection{Timber Harvesting}

Harvesting practices can also remove Ca sources, ranging from $200 \mathrm{~kg} / \mathrm{ha}$ in a clear-cut to almost $1000 \mathrm{~kg} / \mathrm{ha}$ in a multi-entry selective harvesting (Adams et al., 2000). A short-term effect of harvesting is the acidification of soil, which is caused from increased $\mathrm{N}$ cycling rates and increased nitrification and can lead to the release of Al (Adams et al., 2000). The loss of organic matter from harvesting could influence soil moisture retention and cause a lowering of cation exchange capacity (Arthur et al., 2017; Hartman et al., 2012; Jurgensen et al., 1997; Blair and Crossley Jr, 1988; Johnson et al., 1985). Short-term (1- to 5-yr) losses of organic matter after clear-cut have ranged from $2 \mathrm{Mg} / \mathrm{ha}$ to over $150 \mathrm{Mg} / \mathrm{ha}$; this range of loss, especially the higher losses of organic matter, would depend on site preparation and if prescribed burns took place after harvest (Arthur et al., 2015; Jurgensen et al., 1997). Forests that are more susceptible to nutrient depletion from harvest are those that have a large proportion of hickory, oak, yellow-poplar, and basswood as these trees store large amounts of Ca in their trunks (bole wood) (Adams et al., 2000). Harvesting also causes soil compaction from the use of heavy machinery, and compaction reduces water infiltration, which in turn increases surface runoff and nutrient leaching (Hartman et al., 2012).

The species composition of the MNF from Forest Inventory and Analysis (FIA) plots in 1989 had $27 \%$ oaks, $12 \%$ birches, $11 \%$ red maple, with $15 \%$ other hardwoods (Widmann and Griffith, 2000). In 2000, red maple increased by $3.3 \%$ and oaks, sugar maple, hickories, 
American beech, and other conifers decreased. In 2000, the highest amount of dead individual trees across all species were birch (20\%), other hardwoods (17\%), and tulip-poplar (14\%). The percent of dead Northern red oak was found to be highest on sites with surface Al concentrations above $43 \mathrm{cmol}+\mathrm{kg}$, low pH, and low Ca/Al soil ratios (Elias et al., 2009). Some of the tree stand changes could be due to pathogens or diseases such as beech bark disease and acid deposition may have contributed to site susceptibility to insect damage (Elias et al., 2009). Site index was positively correlated with $\mathrm{Ca} / \mathrm{Al}$ molar ratio suggesting that site quality may be influenced by Ca depletion or Al toxicity (Elias et al., 2009). Species composition changes in the MNF may also be due to large fire suppression efforts that have been practiced in US forests since the 1940's (Iverson and Hutchinson, 2002).

The Monongahela National Forest in West Virginia is showing effects of acid soil conditions including stream acidification, missing understory species commonly associated with Appalachian hardwood ecosystems, and indicators of decline in forest growth. Soil scientists on the MNF have conducted analyses of the impacts, costs, and opportunities for liming in some sections of the forest where clear-cutting has been done in the past and is proposed in the near future (Connolly et al., 2007; Elias et al., 2009; Webb et al., 1997).

\section{Experimental Design and Methods}

\subsection{Study Site and Soil Sampling Design}

Soil scientists of the U.S. Forest Service (USFS) selected the Lower Williams Watershed for this study because this watershed, along with the Cherry River Watershed, has some of the highest rates of acid deposition in Appalachia (Figure 1; Farr et al., 2009). The effects of acid deposition over many decades changed the soil chemistry in much of the area, resulting in soil that has a much lower acid-buffering capacity than what likely existed historically before the industrial era (Adams et al., 2000). Soil sampling by the USFS and West Virginia University scientists showed evidence that there is a concern with base cation status and soil quality within the Lower Williams Watershed for soils derived from the Pottsville geology (Connolly et al., 2007; Farr et al., 2009). 


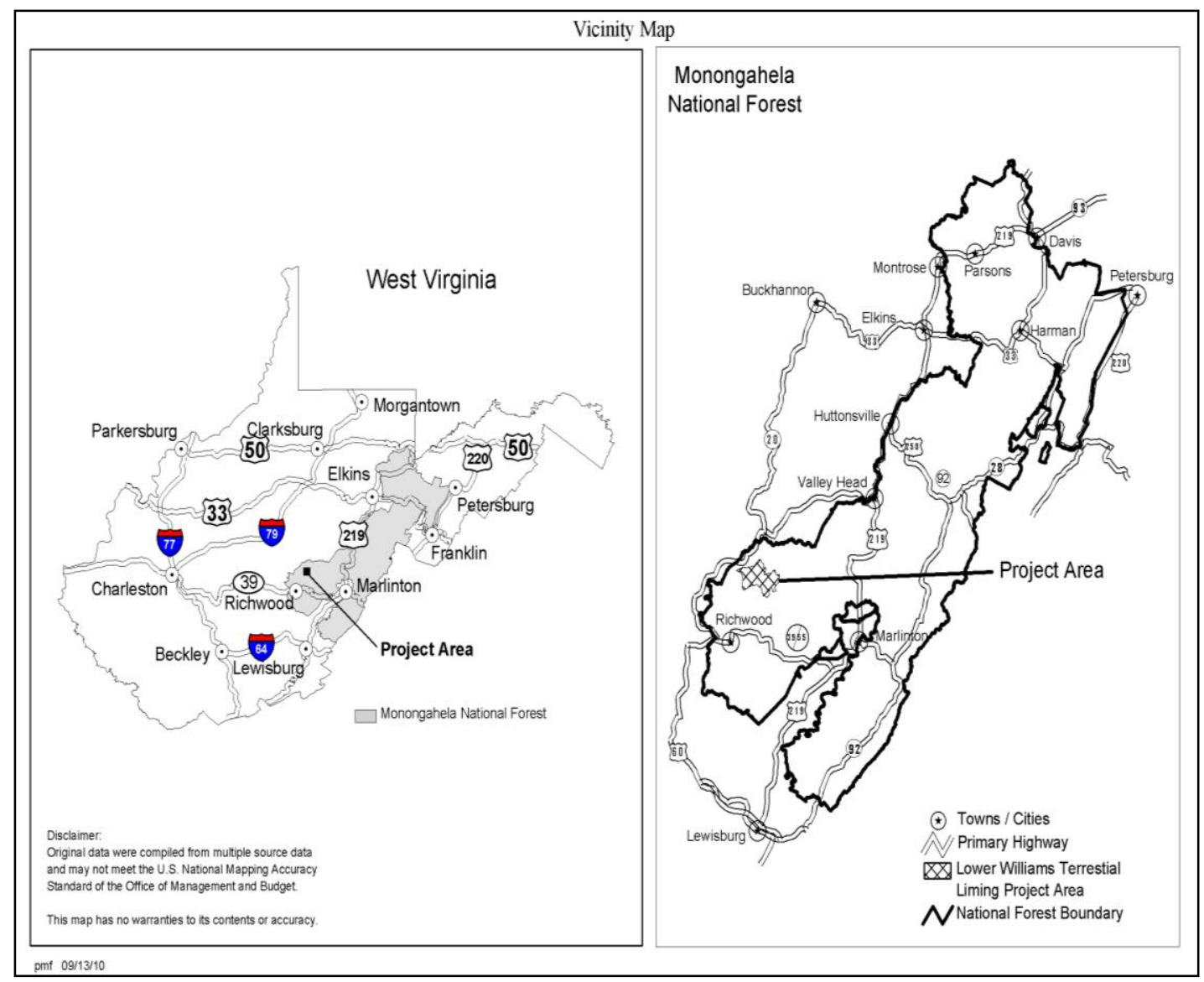

Figure 4. The Lower Williams Terrestrial Liming Project area is located in the Monongahela National Forest, and the project area is located north of Richwood, WV.

In 2007, USFS scientists established areas to be limed amounting to about 284 ha (700 acres) in the watershed (Figure 2). Sampling of the soils on these areas was accomplished by USFS soil scientists in 2007 and 2009 (Figure 2) in anticipation of some future time when liming would be approved. Almost a decade later, after numerous proposals, environmental impact assessments and endangered species studies were performed, approval and funding was provided for the liming project by the USFS. The steep slopes, narrow hollows, and poor road network were problematic to apply lime to the surface by conventional surface application equipment. Therefore, helicopter liming was chosen because of the steep terrain features in the MNF. Liming has been used in Germany to counter forest soil acidification since the mid 1980's (Huettl and Zoettl, 1993) and in North America for watershed experiments (Driscoll et al., 1996; Battles et al., 2014; Johnson et al., 1997; Theenhaus and Schaefer, 1995) and for lake 
and stream remediation (Hudy et al., 2000; DEC, 2014). Application by helicopter has proven to be fairly successful (Driscoll et al., 1996; Battles et al., 2014; Hudy et al., 2000), though wind/weather must be considered before lime application.

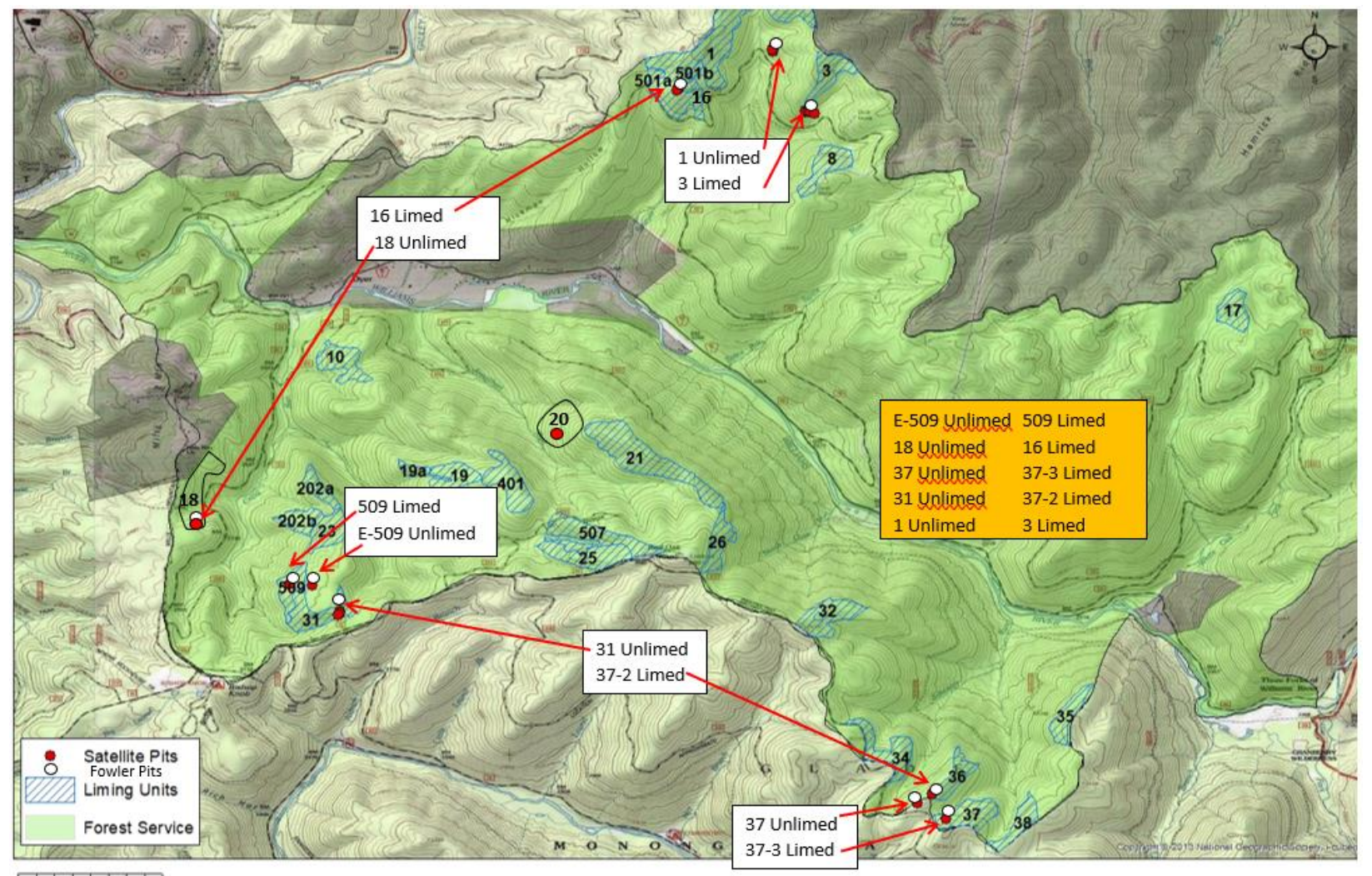

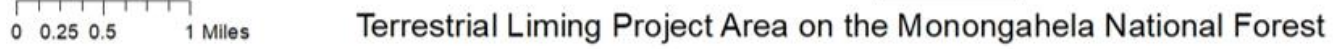

Figure 5. Areas that were limed during this project are shown in the cross-hatched areas and locations of sites and pits for both 2009 and 2019 sampling dates are shown.

\subsection{Liming Application in 2018}

The liming application via helicopter was performed in January and February 2018. The liming rate for the project area was proposed to be 6.7 to $11.2 \mathrm{Mg} / \mathrm{ha}$ ( 3 to 5 tons/ac) and the lime material was composed of sand-sized and small gravel-sized lime. The lime material was obtained from Appalachian Aggregates with a reported $\mathrm{CaCO}_{3}$ content of $87.3 \%$, a $\mathrm{MgCO}_{3}$ content of $3.3 \%$, and a calcium carbonate equivalence (CCE) of $90 \%$. The particle size of the material was $100 \%$ passing a 10 -mesh sieve, $90 \%$ passing a 20 -mesh sieve, $50 \%$ passing a 60 - 
mesh sieve, and $35 \%$ passing a 100 -mesh sieve. Therefore, more than $50 \%$ of the material was small sand-sized material. The lime particle size allowed it to fall from the helicopter hopper onto the land surface with less scattering due to wind drafts from natural sources and the helicopter blades. It was deemed that silt-sized and smaller lime particles, such as those used in agricultural liming practices, were too fine and would be dispersed by wind with lesser amounts falling on the designated areas. During the lime application, scientists with the USFS used a collection pan to determine the liming rate applied by the helicopter; their results demonstrated that the lime applied was within the desired liming rate of 6.7 to $11.2 \mathrm{Mg} / \mathrm{ha}$ (3 to 5 tons/acre).

\subsection{Soil Sample Data Collection}

Soil sampling sites for 2019 were pre-selected by USFS and WVU scientists from those established by the USFS in 2007 and 2009 (simplified to 2009, Figure 2). After liming in February 2018, soil sampling and analysis were projected to be accomplished in years one, three, and five following liming application. A total of ten (10) sampling sites were selected based on the original sampling in 2009 and GIS coordinates were provided by the USFS (Figures 3-6) so that the sites could be found and resampled. The accuracy of the handheld Garmin GPS was within 3 $\mathrm{m}(10 \mathrm{ft})$ of the given coordinates. Before soil sampling, the \% slope (using a Suunto clinometer) and aspect (in degrees using a multifunction compass) were recorded, as well as the date, time, and current weather conditions. Sampling locations were paired so that each pair of sites had an unlimed and a limed area. The pairs were E-509 and 509, 37 and 37-3, 31 and 37-2, 1 and 3, and 18 and 16 (Figure 2). This allowed for similar soils at each pair of sites. These pairs were within 300 m of each other and on a similar landscape position (Table 1).

As shown in the following maps (Figures 3-6), the pit locations were extremely close to where the original sampling locations were in 2009, except for sites 37, 37-2, and 31. Site 31 was moved North of the original location due to disturbance from heavy machinery used for logging (Figure 4). The new site was within $30 \mathrm{~m}$ of the original site and along the contour. Site 37 was moved to the east (left, Figure 5) because after the original sampling date a road was made for the heavy machinery used for timbering which traversed the original pit locations. 
After finding our location, we were unable to sample using cardinal directions because of the road. The only option was to sample along the contour with the sampling pits being $15 \mathrm{~m}$ (50ft) apart. Site 37-2 was moved to a nearby location because two fallen trees and other deadfall covered the original location (Figure 5).

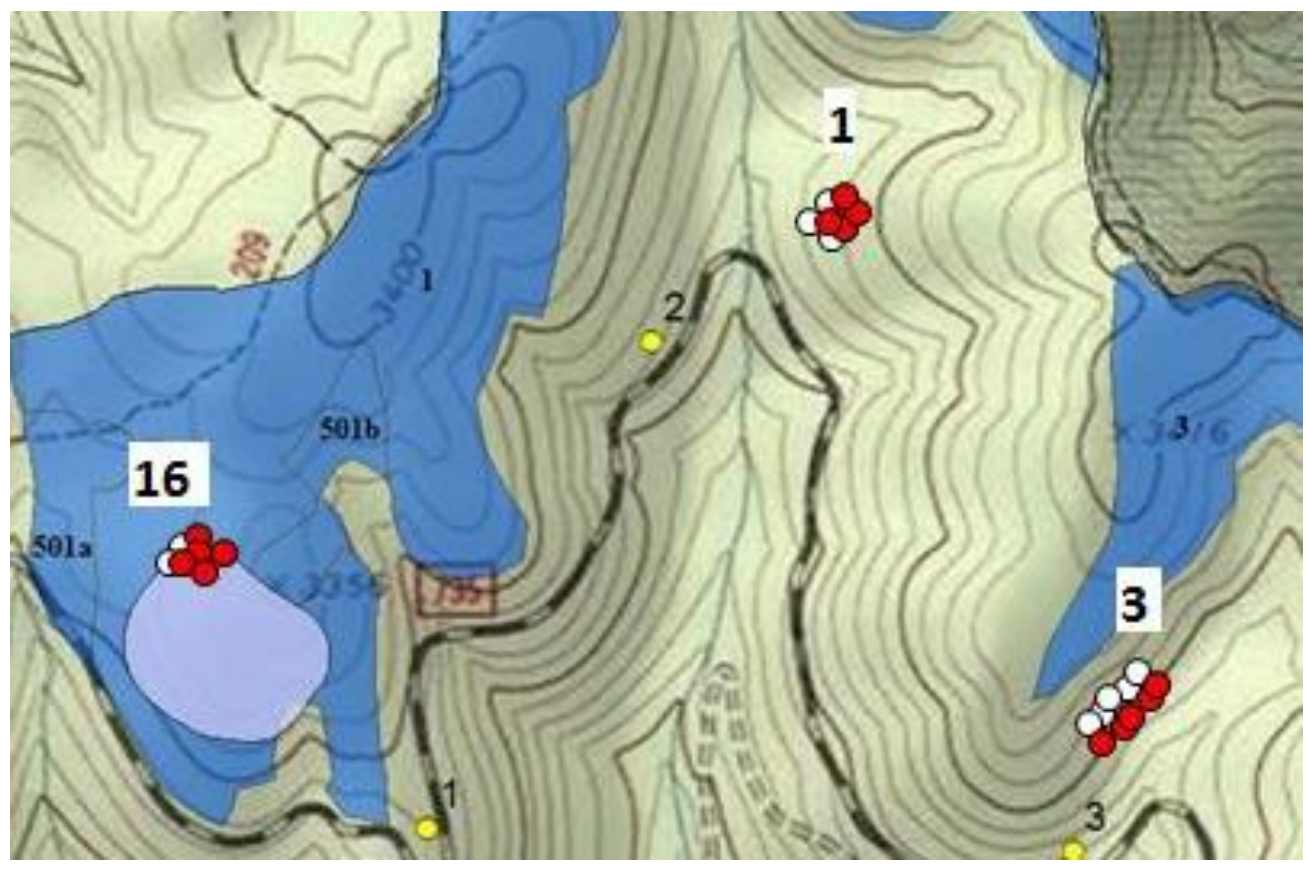

Figure 6. Map showing sampling locations from 2009 (red) and from 2019 (white) for sites 1, 3, and 16 on the northern extremity of the project area (see Figure 5 for relative location of these sites within the project area). 


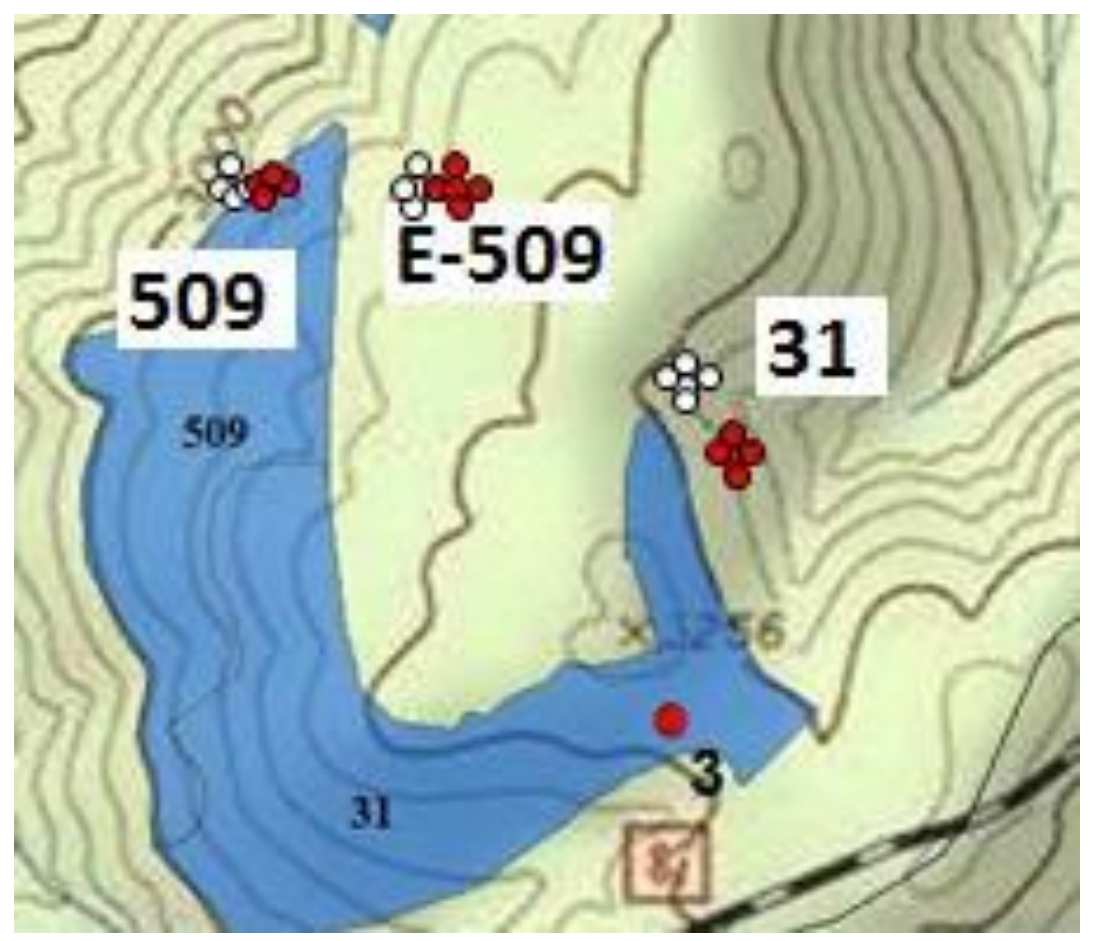

Figure 7. Map showing sampling locations from 2009 (red) and from 2019 (white) for sites E509, 509, and 31.

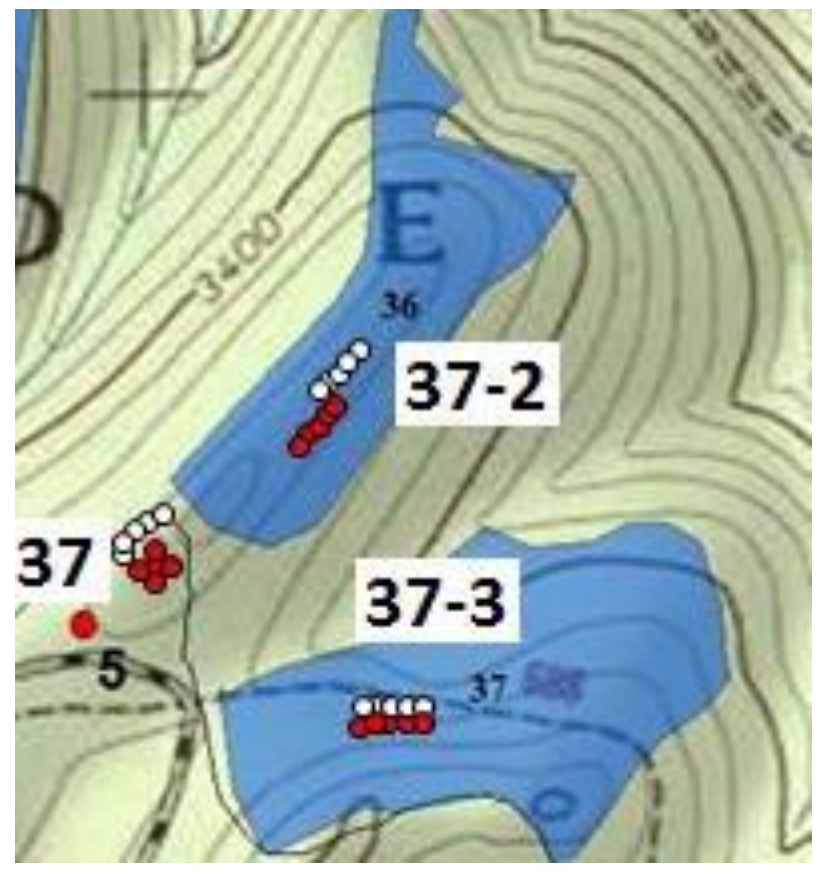

Figure 8. Map showing sampling locations from 2009 (red) and from 2019 (white) for sites 37, 37-2, and 37-3. 


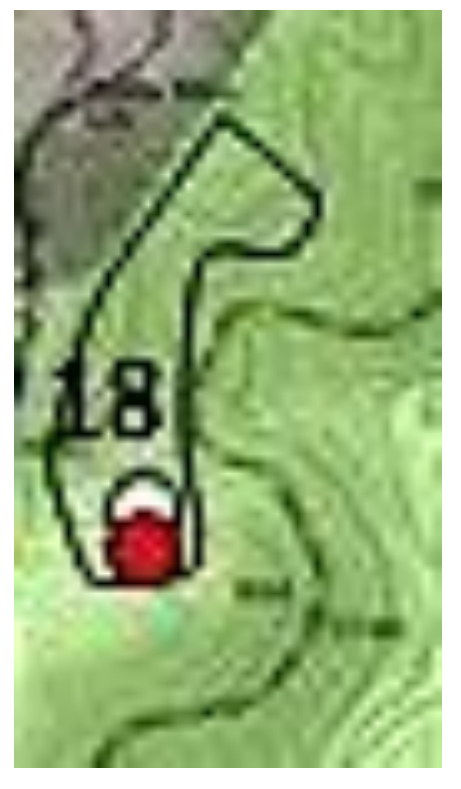

Figure 9. Map showing sampling locations from 2009 (red) and from 2019 (white) for site 18.

Table 2. Soil samples were extracted from $0, A$, and upper B Horizons at 10 site locations (see Figure 5 for site numbers) with and without liming treatment. Aspect and slope $\%$ are also provided for each site.

\begin{tabular}{cccc}
\hline Site Number & Limed or Unlimed & Aspect & Slope \% \\
\hline E-509 & Unlimed & W & 15 \\
37 & Unlimed & NW & 16 \\
31 & Unlimed & W & 6 \\
1 & Unlimed & W & 15 \\
18 & Unlimed & N & 28 \\
509 & Limed & W & 14 \\
$37-3$ & Limed & N & 15 \\
$37-2$ & Limed & NW & 3 \\
3 & Limed & SE & 30 \\
16 & Limed & NW & 20 \\
\hline
\end{tabular}


Based on demonstrations and conversations with USFS scientists, soil sampling and collection were performed using the same techniques as were done previously in 2009. At each site, five small holes were dug (pits were from 30 to $50 \mathrm{~cm}$ in total depth (12 to 20 inches) based on the depth of the B horizon): the first at the GPS coordinate, and the other four at

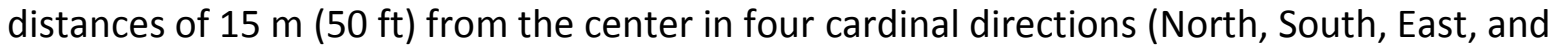
West) or along the contour of the slope if topography did not allow use of cardinal directions. In each pit, soil samples were collected from the $O, A$, and upper B horizons. The faces of the sampling pits were always facing upslope and the pits were dug $20 \mathrm{~cm}$ below the boundary of the $A$ and $B$ horizon. Knives were used to mark the horizon boundaries and a tape was placed to determine the depths of horizons. Pictures were taken of each profile (see appendix). Color was the primary determining factor for separating horizons, but changes in soil texture, bulk density, and root density were also used.

Soil sampling began in the bottom of each hole with the upper B horizon and progressed upwards to the $\mathrm{A}$ and $\mathrm{O}$ horizons. The amount of soil collected was around two liters and care was taken to stay several $\mathrm{cm}$ from horizon boundaries. Before sampling the next horizon, the knife, handheld shovel, and dustpan were wiped clean. Soil samples were labelled with the site number, the cardinal direction, date, horizon, and depth. Table 1 shows the sites sampled and their treatment designations and site conditions. A total of 15 soil samples were collected at each of the 10 sites ( 10 sites $x$ five pits $x$ three horizons) for a total of 150 soil samples for the project.

Upon completion of sampling, the soil samples were transported to the WVU Greenhouse and the soils were air-dried for two weeks. Soil samples were processed by drying, removing large rocks, sieving through a $2 \mathrm{~mm}$ sieve (corresponding to soil-sized particles $2 \mathrm{~mm}$ or less), bagging and labelling. Approximately one liter of soil from each sample was sent to the University of Maine soil testing laboratory for analysis of $\mathrm{pH}$, effective cation exchange capacity (ECEC), \% OM (LOI), \% total carbon, \% total nitrogen, $\mathrm{P}, \mathrm{K}, \mathrm{Ca}, \mathrm{Mg}, \mathrm{Na}, \mathrm{Al}, \mathrm{Fe}, \mathrm{Mn}$, and $\mathrm{Zn}$. In addition to the soil samples collected in 2019 , soils collected during the 2009 sampling were also sent to the University of Maine soil testing laboratory for analysis. The soil analysis data 
obtained from the 2009 sampling was compared to the data collected in 2019, and comparisons were made between the years of sampling and among sites.

\subsection{Soil Analysis at University of Maine}

Soil testing procedures at the University of Maine Soil Testing Lab are listed below. The soil testing package selected was their "Forest Soil Package." Soil pH was measured in 1:1 ratio of soil:water. Organic matter was measured by loss on ignition (LOI) at $550^{\circ} \mathrm{C}$. Total nitrogen and carbon were measured by combustion analysis at $1350^{\circ} \mathrm{C}$. Exchangeable acidity was extracted with $1 \mathrm{M}$ potassium chloride $(\mathrm{KCl})$ and titrated. Exchangeable cations were extracted in $1 \mathrm{M}$ ammonium chloride $\left(\mathrm{NH}_{4} \mathrm{Cl}\right)$ and measured by ICP-OES. Effective cation exchange capacity (ECEC) was calculated by summing the milliequivalent concentrations of $\mathrm{Ca}, \mathrm{K}, \mathrm{Mg}, \mathrm{Na}$, and acidity. The 15 parameters for which we obtained data were $\mathrm{pH}$, acidity, ECEC, \%OM, \%TC, \%TN, P, K, Ca Mg, Na, Al, Fe, Mn, and Zn.

\section{Statistical Analysis}

The statistical analyses followed the pattern outlined in Figure 7 (the descriptions in Figure 7 were written by the WVU Experiment Station statistician, Dr. Ida Holaskova). The analysis attempted to evaluate differences in soil properties between paired sites within 2009 (analysis 1), the same sites across years (analysis 3 and 4), and the effect of liming with paired sites in 2019 (analysis 2). Each of the five main locations (A, B, C, D, E) had two paired sites within it, one not limed (UL) and one limed ( $L$ ) as indicated in Figure 2 and Table 1. The unusual feature of this analysis was that none of the sites in 2009 were limed (un)L, thus this was not a regular factorial design. To minimize statistical confounding of the effect of year and liming, this alternative analytical approach was selected. Data were analyzed using JMP and SAS software $\left(\mathrm{JMP}^{\circledR}\right.$, Version Pro 14.0, SAS Institute Inc., Cary, NC, Copyright C2015; SAS ${ }^{\circledR}$, Version 9.4, SAS Institute Inc., Cary, NC, Copyright (C2002-2012) and the term "slice" as used in Figure 7 allowed for comparisons between each pair of sites. 


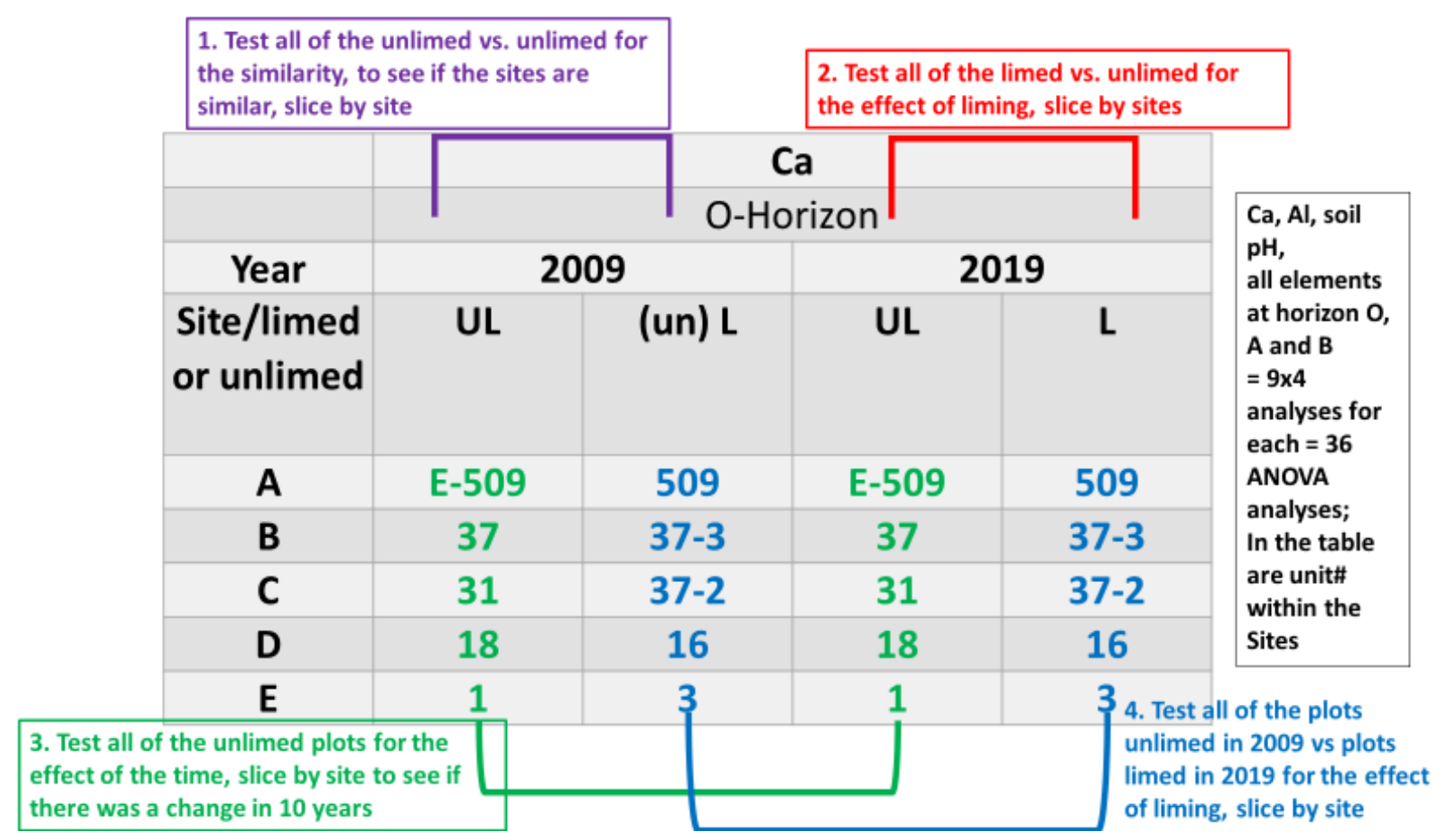

Figure 10. Data for each parameter were separated and analyzed based on horizon $(O, A, B)$, year of sampling (2009 vs 2019), liming treatment (UL vs L), and interactions. Interactions included sites within liming treatment within years (designated by 1 (purple) and 2 (red)), sites within liming treatment across years (designated by 3 (green) and 4 (blue)).

All continuous response variables (soil elements tested at the University Maine and other soil characteristics) were examined for normal distribution using the Shapiro-Wilk W test (Shapiro, and Wilk, 1965). Natural log transformation was used for eight of the tested parameters with right skewness ( $\mathrm{Ca}, \mathrm{Mg}, \mathrm{P}, \mathrm{Mn}, \mathrm{Zn}, \mathrm{Fe}, \% \mathrm{OM}$, and \%TN), and fourth power transformation was used for soil $\mathrm{pH}$. The overall means and standard errors are reported in tables in untransformed format for clarity, but significant differences are based on the statistical analysis of the transformed data.

The soil data were analyzed in two steps. The first set of analyses tested main effects of liming ( $U L$ and $L$ ) and site $(A, B, C, D, E)$ and their interaction within each sampling year (analysis 1 and 2 in Figure 7). The liming, sites, and years were considered as fixed effects. We hypothesized that the soils at paired sites sampled in 2009 would have similar values for all parameters since they were close to each other and there had been no soil treatment. The data 
from 2019 between the Limed and Unlimed sites was hypothesized to be different. In addition to ANOVA, comparisons were done between paired sites and among the sites within each liming treatment and year using Tukey-Kramer with adjustment to multiple comparisons (Dubitzky et al., 2013).

The second set of analyses included repeated measures (RM) ANOVA within each liming treatment to estimate the effect of year and its interaction with sites. The sites were considered as fixed effects, and year as a repeated measure to test the effect of the $10-y r$ interval on soil parameters. The PROC MIXED procedure of SAS was utilized. The effect of time (2009 vs 2019, the 10-yr interval) on soil changes was assessed by comparing the Unlimed plots in 2009 vs 2019. The most direct comparison of the effect of liming on the soil parameters was RM ANOVA on data comparing 2009 To Be Limed vs 2019 Limed. The pairwise comparisons were done between the paired sites and among the sites within each liming treatment and year using Tukey-Kramer with adjustment to multiple comparisons. All the analyses were done for each horizon separately $(\mathrm{O}, \mathrm{A}$, and $\mathrm{B})$ and for lime treatment (UL or L). Statistical differences were considered significant at the $p<0.05$ level.

Graphs were developed from the data in tables for better illustration of differences among sites and years using violin plots. The graphing software used was run in R Studio (RStudio Team, 2020), the code in R Studio was written by Matthew Walker, using installed packages of tidyverse (Wickham et al., 2019), ggplot2 (Wickham, 2016), plyr (Wickham, 2011), dplyr (Wickham et al., 2020), ggpubr (Kassambara, 2020), and cowplot (Wilke, 2020).

In all statistical analyses, significance criterion alpha for all tests was 0.05 . Due to multiple ANOVA analyses, Benjamini-Hochberg procedure was applied to control the familywise error rate, using False Discovery Rate (FDR) of 0.1.

\section{Results}

The averages of the parameters among sites for each horizon within a treatment were found to be very similar. Appendix 1 provides those averages for each site and compares the sites within each treatment. Few significant and practical differences were found among sites 
within treatments for all 15 parameters. Therefore, these sites were suitable replications in this study. From now on, in the text only averages for each treatment (including five sites for each) will be shown. As mentioned, all average values from each site can be found in Appendix 1.

\section{$4.1 \mathrm{pH}$}

The $\mathrm{pH}$ levels of organic material in acid forest soils in Appalachia range from 3.5 to 4.6 (Connolly et al., 2007; Farr et al., 2009). The A and B horizons show slightly higher pH values from 4.0 to 5.0. In our study, O horizons in 2009 ranged from 3.9 to 4.9 across all sites and averaged 4.3 and 4.2, respectively, for the Unlimed and the To Be Limed sites (Appendix 1Table 21 and Table 3). As mentioned above, values were very consistent within the five pits on each site so that even small differences in average soil pH values between treatments in 2009 were significant (Table 3, superscript \#). Soil pH of the $\mathrm{O}$ horizon on Unlimed sites in 2009 had an average of 4.3, which was significantly lower than those same sites in 2019 with an average of 4.6 (Table 3, superscript ${ }^{U}$ ). As expected, the To Be Limed sites in 2009 were significantly lower in $\mathrm{pH}(4.2)$ than the same sites 10 years later and after liming (5.6; Table 3, superscript ${ }^{\mathrm{L}}$ ).

In 2019, significant soil pH differences were expected for the Unlimed sites with an average of 4.6 compared to the Limed sites with an average $\mathrm{pH}$ of 5.9 (Table 3, superscript \#). For the $\mathrm{O}$ horizon, it was expected that liming would raise $\mathrm{pH}$, but it should be noted that the higher $\mathrm{pH}$ was largely due to the presence of unreacted lime particles during sample collection rather than the actual dissolution of lime and incorporation of lime into the organic matter. The large particle size of the lime that was applied would not be expected to have dissolved and be incorporated into organic matter or to have entered the soil in the one-year time frame. Hence, the higher $\mathrm{pH}$ was undoubtedly due to lime particles mixed with the organic matter and that undissolved lime in our samples caused the rise in $\mathrm{pH}$ when the laboratory $\mathrm{pH}$ test was performed.

For the A horizon, similar results were found except that the average $\mathrm{pH}$ values were 0.3 to $0.5 \mathrm{pH}$ units lower than for $\mathrm{O}$ horizons (Table 3). In 2009, average values were significantly different between the Unlimed and To Be Limed sites (3.9 vs. 3.7 \#). The Unlimed sites in 2009 were significantly lower the Unlimed sites in 2019 (3.9 vs $4.3^{4}$ ). However, the A horizons at 
Limed sites in 2019 averaged 4.6 (considerably lower than the 5.9 in the 0 horizon) and yet were significantly higher than the To Be Limed sites in 2009 (3.7 vs 4.6 L) and the Unlimed sites in 2019 (4.3 vs $4.6^{\mathrm{L}}$ ).

Differences in soil pH in B horizons were much smaller in 2009 having $\mathrm{pH}$ values in the Unlimed and To Be Limed sites (4.5 vs $4.3^{\#}$ ). The $\mathrm{pH}$ values in 2019 were about $0.3 \mathrm{pH}$ units higher than those in 2009, and the Unlimed and Limed sites were not significantly different with averages of 4.8 and 4.7, respectively. Average soil $\mathrm{pH}$ was generally lowest in A horizons and highest in B horizons (Table 3).

Table 3. Average soil pH values in $\mathrm{O}, \mathrm{A}$, and $\mathrm{B}$ horizons for sites sampled in the Terrestrial Liming Project. See footnotes for explanations of statistical comparison among sites, within and across years, and with liming treatment.

\begin{tabular}{|c|c|c|c|c|}
\hline \multirow{2}{*}{ Average $\mathrm{pH}$} & \multicolumn{2}{|c|}{2009} & \multicolumn{2}{c|}{2019} \\
\hline \multirow{2}{*}{ Horizon } & \multicolumn{2}{|c|}{ Treatments } & \multicolumn{2}{c|}{ Treatments } \\
\cline { 2 - 5 } & Unlimed & To be Limed & Unlimed & Limed \\
\hline $\mathrm{O}$ & $4.3 \pm 0.06$ & $4.2 \pm 0.06^{\#}$ & $4.6 \pm 0.08^{\mathrm{U}}$ & $5.9 \pm 0.08^{\# \mathrm{~L}}$ \\
\hline $\mathrm{A}$ & $3.9 \pm 0.03$ & $3.7 \pm 0.03^{\#}$ & $4.3 \pm 0.06^{\mathrm{U}}$ & $4.6 \pm 0.06^{\mathrm{L}}$ \\
\hline $\mathrm{B}$ & $4.5 \pm 0.05$ & $4.3 \pm 0.05^{\#}$ & $4.8 \pm 0.03^{\mathrm{U}}$ & $4.7 \pm 0.03^{\mathrm{L}}$ \\
\hline
\end{tabular}

\# Indicates significant main effect of treatment (average of Unlimed vs Limed sites) within year. ${ }^{U}$ Indicates significant main effect of year (average of 2009 vs 2019 sites) within Unlimed treatment. L Indicates significant main effect of year (average of 2009 vs 2019 sites) within To be Limed vs Limed.

To graphically illustrate the data in Table 3, violin plots were constructed. These plots show each $\mathrm{pH}$ value for each horizon from each year and treatment $(n=25)$. For example, the first plot for the $\mathrm{O}$ horizon in Figure 11, gives the $\mathrm{pH}$ values for all 25 soil samples taken from the 2009 Unlimed sites (five sites $x$ five pits $x$ one horizon). The first blue violin plot (pH of the 2009, O horizon, UL) shows a rather flat form and the height of the form is based on the range of values from highest to lowest. The width of the forms illustrates the number of data points at that $\mathrm{pH}$ level. Inside each form is a box that shows data quartiles and the median (see description in Figure 11). As revealed in the Tables ( 3 and Appendix 1 ) and more easily seen in Figure 11, the 2009 UL, 2009 To Be Limed and the 2019 Unlimed soils in the O horizon were relatively similar in shape: flat and wide. The $\mathrm{pH}$ values for 2019 Limed O horizon soils were 
clearly higher with a wider range (taller form) of values. Soil $\mathrm{pH}$ in the $\mathrm{A}$ and $\mathrm{B}$ horizons were more similar but appeared to be slightly higher in 2019 compared to 2009.

Figure 11. Violin plot of $\mathrm{pH}$ from both treatments in 2009 and 2019 showing the $\mathrm{pH}$ level differences between years, treatments, and soil horizons as indicated in Table 3. The top and bottom of the violin plot indicate the lowest and highest values (range of values). The width of the violin plot indicates the frequency of values in that area of the plot. The box within shows the first and third quartile and the line gives the median. Violin plots provide a visual representation of each parameter and show how the sites compared between treatments within years and between 2009 to 2019 for the O, A and B horizons.
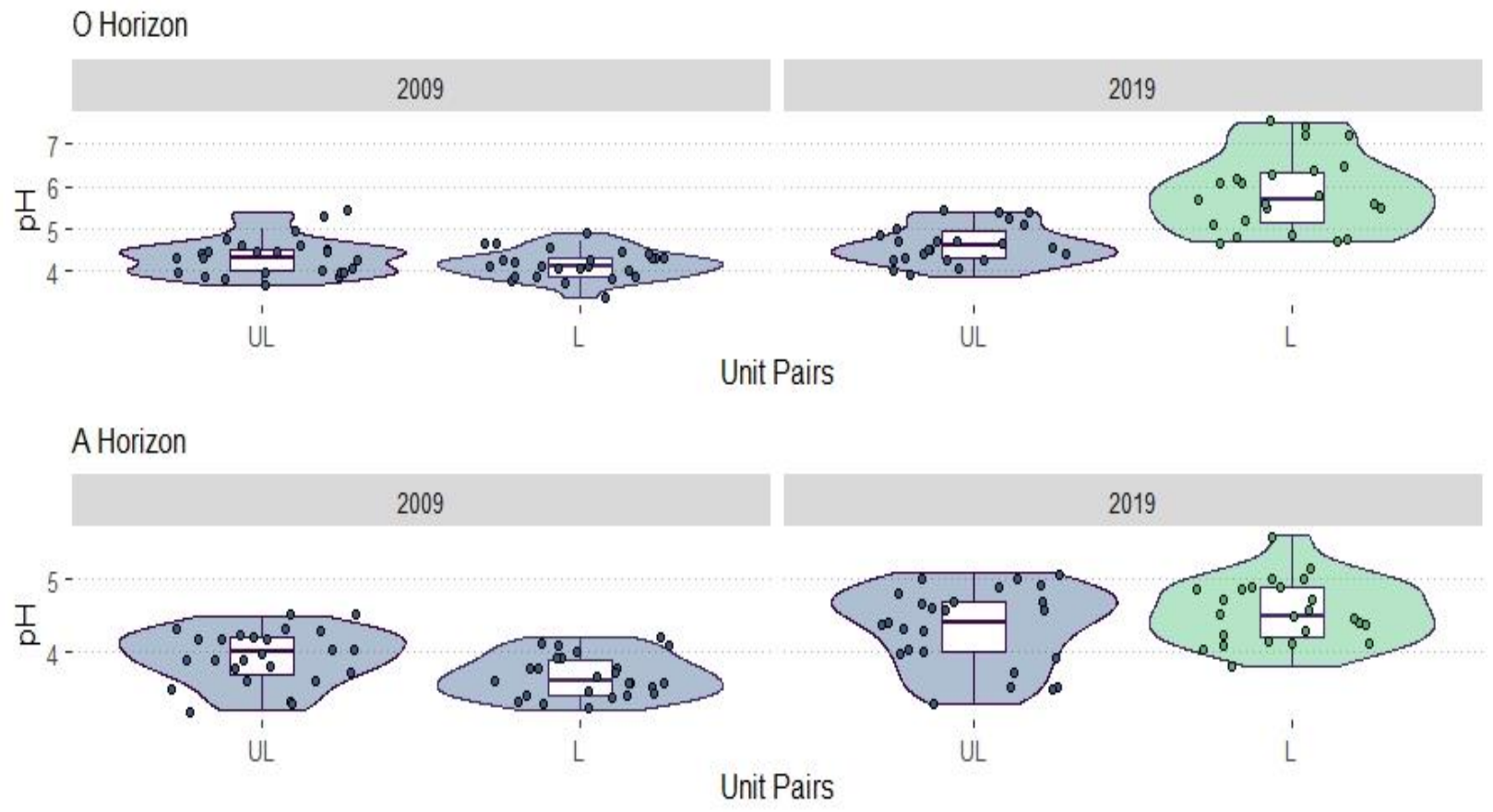

B Horizon

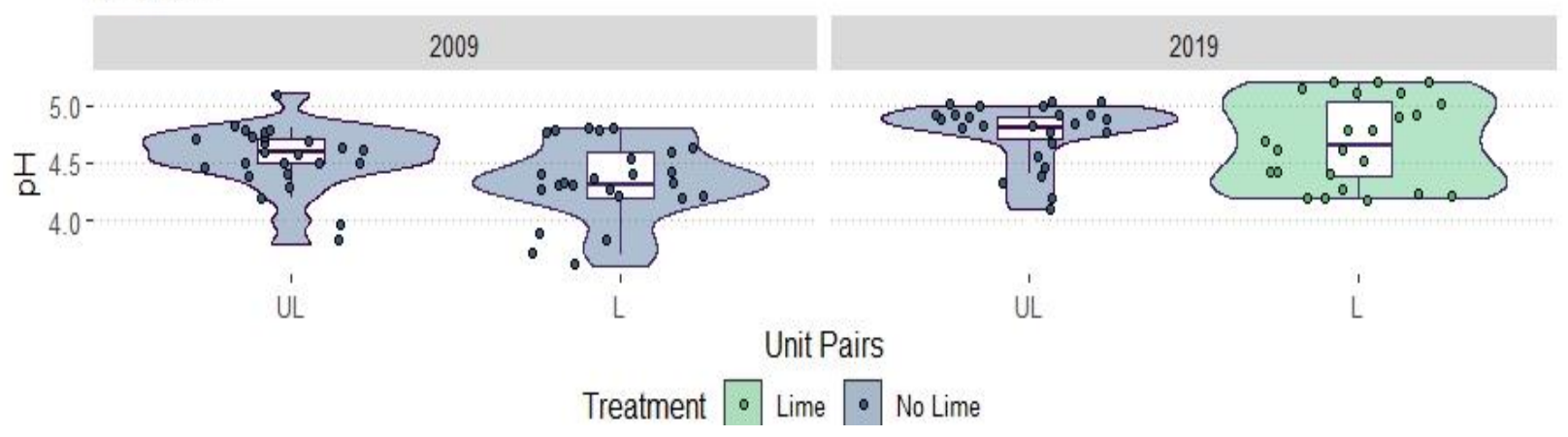




\subsection{Acidity}

The acidity levels of organic material in acid forest soils in Appalachia range from 6.2 to $9.4 \mathrm{cmol}^{+} / \mathrm{kg}$ (Farr et al., 2009). The A and B horizons show slightly lower acidity values from 3.7 to $9.4 \mathrm{cmol}^{+} / \mathrm{kg}$. In our study, O horizons in 2009 averaged $7.0 \mathrm{cmol}^{+} / \mathrm{kg}$ for both the Unlimed and To Be Limed sites (Table 4). For the Unlimed treatments, acidity levels were significantly greater in 2019 vs 2009 (7 vs $11 \mathrm{cmol}+/ \mathrm{kg}$ U) (Table 4). The To Be Limed sites in 2009 and the Unlimed sites in 2019 were both significantly higher in acidity than the 2019 Limed sites (superscripts \#L) (Table 4).

Acidity values in A horizons mirrored the trends in the 0 horizon; sites in 2009 did not vary in average values, and the Unlimed sites in 2019 were almost double the average acidity values in Limed sites. Acidity values in B horizons showed only slight differences with averages ranging from 6 to $8 \mathrm{cmol}+/ \mathrm{kg}$. Average soil acidity was generally lowest in the $\mathrm{B}$ horizons and highest in the A horizons (Table 4).

Table 4. Average acidity values $\left(\mathrm{cmol}^{+} / \mathrm{kg}\right)$ in $\mathrm{O}, \mathrm{A}$, and $\mathrm{B}$ horizons for sites sampled in the Terrestrial Liming Project. See footnotes in Table 3 for letter and symbol descriptions.

\begin{tabular}{|c|c|c|c|c|}
\hline Average Acidity & \multicolumn{2}{|c|}{2009} & \multicolumn{2}{c|}{2019} \\
\hline \multirow{2}{*}{ Horizon } & \multicolumn{2}{|c|}{ Treatments } & \multicolumn{2}{c|}{ Treatments } \\
\cline { 2 - 5 } & Unlimed & To be Limed & Unlimed & Limed \\
\hline O & $7 \pm 0.5$ & $7 \pm 0.5$ & $11 \pm 1.0^{\mathrm{U}}$ & $3 \pm 1.0^{\# \mathrm{~L}}$ \\
\hline $\mathrm{A}$ & $8 \pm 1.0$ & $9 \pm 1.0$ & $11 \pm 0.5^{\mathrm{U}}$ & $6 \pm 0.5^{\# \mathrm{~L}}$ \\
\hline $\mathrm{B}$ & $6 \pm 0.4$ & $7 \pm 0.4$ & $7 \pm 0.4^{\mathrm{U}}$ & $8 \pm 0.4$ \\
\hline
\end{tabular}

The violin plots of acidity show that acidity appears to be slightly higher in Unlimed sites in 2019 compared to the sites in 2009 in the O horizon, and that the 2019 Limed sites were lower than the others. In A horizons, the 2019 Limed sites appear to be lower than the others, and there appears to be little difference in acidity in B horizons.

Figure 12. Violin plot of Acidity from both treatments in 2009 and 2019 showing the acidity $\left(\mathrm{cmol}^{+} / \mathrm{kg}\right.$ ) differences between years, treatments, and soil horizons as indicated in Table 4 (see description of violin plots in Figure 11). 

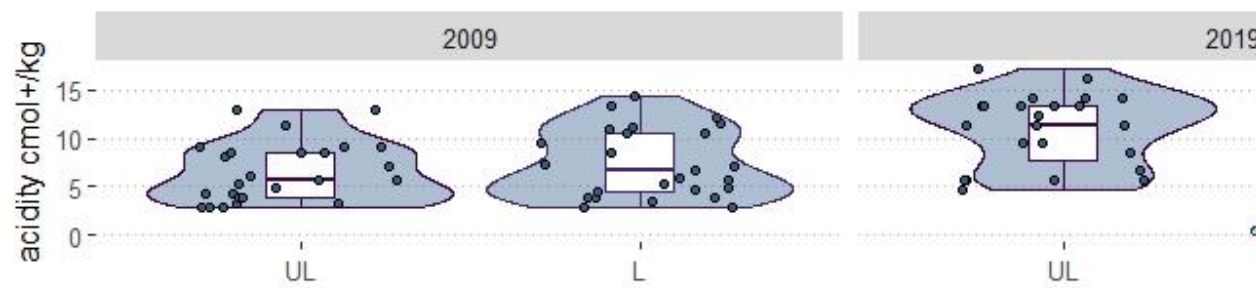

Unit Pairs

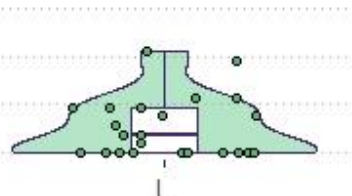

A Horizon

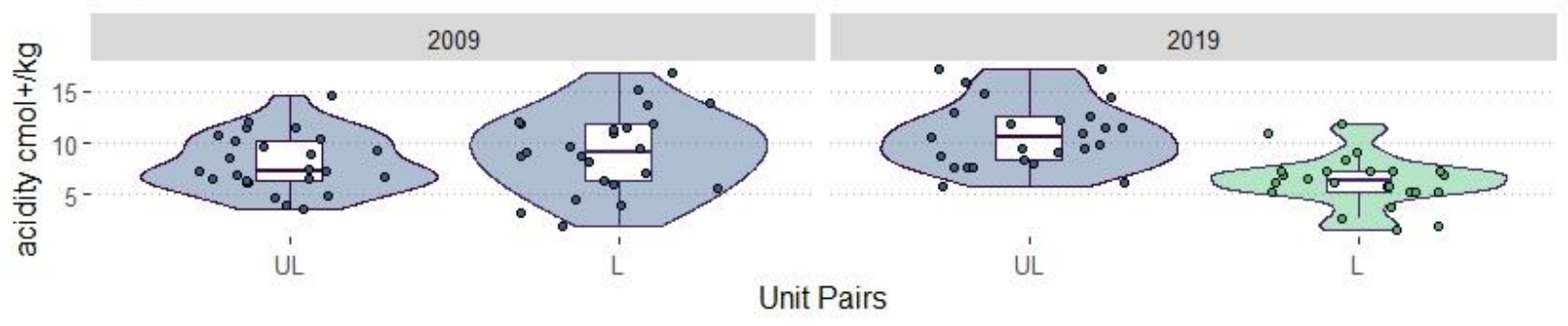

B Horizon

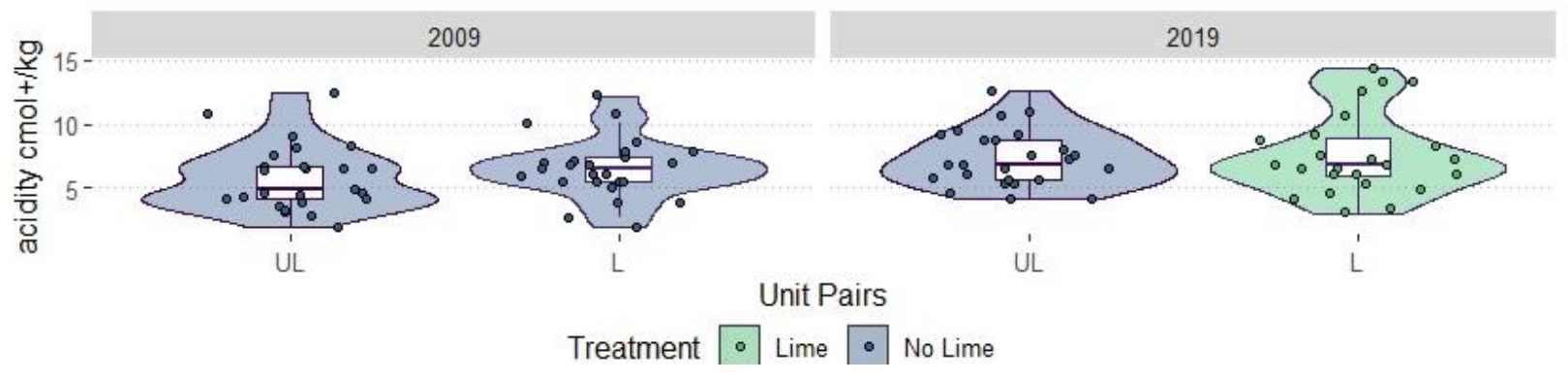

\subsection{ECEC}

The ECEC levels of organic material in acid forest soils in Appalachia range from 7.2 to $10.7 \mathrm{cmol}^{+} / \mathrm{kg}$ (Farr et al., 2009). The $A$ and $B$ horizons showed much lower but also similar ECEC values from 4.0 to $10.7 \mathrm{cmol}^{+} / \mathrm{kg}$. In our study, O horizons in 2009 averaged 19.0 and 20.0 $\mathrm{cmol}^{+} / \mathrm{kg}$ for the Unlimed and the To Be Limed sites (Table 5). For the Unlimed treatments in 2009 vs 2019, ECEC levels were significantly lower in 2009 vs 2019 (19 vs 22 U). The To Be Limed sites in 2009 and the Unlimed sites in 2019 were both significantly lower in ECEC than the 2019 Limed sites ( 20 and 22 vs $33 \mathrm{cmol}+/ \mathrm{kg}$ \# L). ECEC values in A horizons had identical average values in 2009 (10) and the Unlimed sites in 2019 being significantly higher than the Limed sites in 2019 (12 vs $10^{\#}$ ). ECEC values in B horizons showed minor differences with average totals ranging from 6 to $8 \mathrm{cmol}+/ \mathrm{kg}$ (Table 5). Average ECEC was generally lowest in the $\mathrm{B}$ horizons and highest in the $\mathrm{O}$ horizons (Table 5). 
Table 5. Average ECEC values ( $\mathrm{cmol}+\mathrm{kg}$ ) in $\mathrm{O}, \mathrm{A}$, and $\mathrm{B}$ horizons for sites sampled in the Terrestrial Liming Project. See footnotes in Table 3 for letter and symbol descriptions.

\begin{tabular}{|c|c|c|c|c|}
\hline Average ECEC & \multicolumn{2}{|c|}{2009} & \multicolumn{2}{c|}{2019} \\
\hline \multirow{2}{*}{ Horizon } & \multicolumn{2}{|c|}{ Treatments } & \multicolumn{2}{c|}{ Treatments } \\
\cline { 2 - 5 } & Unlimed & To be Limed & Unlimed & Limed \\
\hline O & $19 \pm 1.0$ & $20 \pm 1.0$ & $22 \pm 2.0^{U}$ & $33 \pm 2.0^{\# \mathrm{~L}}$ \\
\hline A & $10 \pm 1.0$ & $10 \pm 1.0$ & $12 \pm 1.0^{\mathrm{U}}$ & $10 \pm 1.0^{\#}$ \\
\hline B & $6 \pm 0.4$ & $7 \pm 0.4$ & $8 \pm 0.4^{U}$ & $8 \pm 0.4$ \\
\hline
\end{tabular}

Forms for the values of ECEC were very flat and wide, meaning that they were very consistent in 2009 and in the 2019 Unlimed sites compared to the plot form for 2019 Limed sites in $O$ horizons (Figure 13). Forms for the data showed more variation in the $A$ and $B$ horizons and they overlapped with each other.

Figure 13. Violin plot of ECEC from both treatments in 2009 and 2019 showing the ECEC $(\mathrm{cmol}+/ \mathrm{kg})$ differences between the years, treatments, and soil horizons as indicated in Table 5 (see description in Figure 11). 

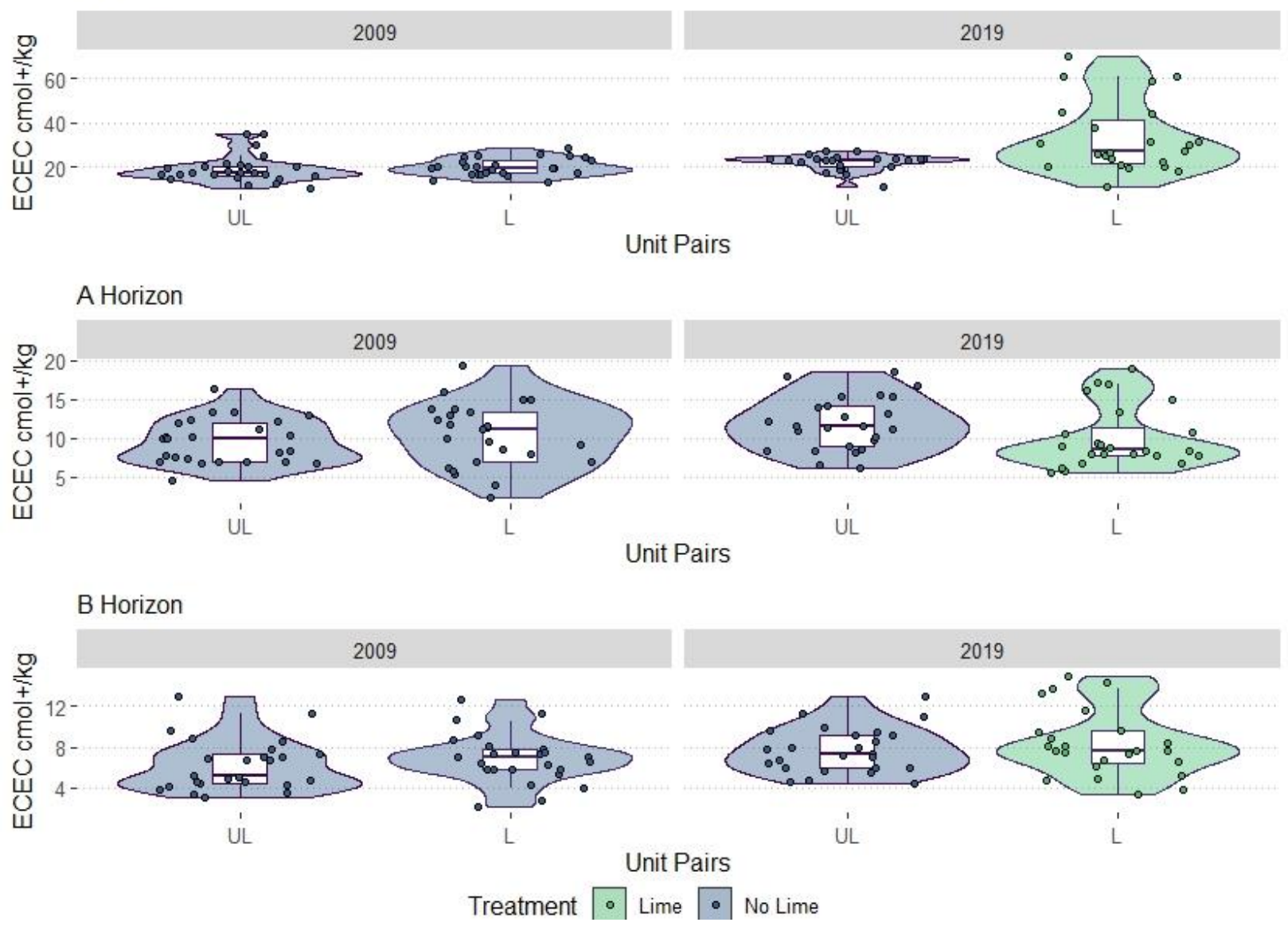

\section{$4.4 \%$ OM}

The \% OM in O horizons of Appalachian forest soils range from 28 to 53\% (Bailey et al., 2005; Garten Jr et al., 1999). The A horizons showed lower \% OM values from 14 to 27\%. In our study, O horizons in 2009 averaged 54 and 68\% for the Unlimed and the To Be Limed sites (Table 6). In 2009, \% OM levels varied significantly in O horizons within treatments (54 vs 68 \#, Table 6). For the Unlimed treatments in 2009 vs 2019, \% OM was significantly different (54 vs 58 U). The To Be Limed sites in 2009 and the Unlimed sites in 2019 were both significantly higher in \% OM than the 2019 Limed sites (68 and 58 vs $35^{\# L}$ ). The higher pH levels in the Limed 2019 sites may have increased microbial growth, thereby decreasing \% OM. Organic matter values in A horizons were three times lower than those in the O horizon (Table 6). Sites in 2009 did not vary much in average values and were not significantly different, but the To Be 
Limed sites in 2009 and the Unlimed sites in 2019 were significantly higher than the Limed sites in 2019. Values in B horizons showed almost no differences. As one would expect, average \% OM was lowest in the B horizons and highest in the $O$ horizons (Table 6).

Table 6. Average \% OM values (\%) in O, A, and B horizons for sites sampled in the Terrestrial Liming Project. See footnotes in Table 3 for letter and symbol descriptions.

\begin{tabular}{|c|c|c|c|c|}
\hline Average \% OM & \multicolumn{2}{|c|}{2009} & \multicolumn{2}{c|}{2019} \\
\hline \multirow{2}{*}{ Horizon } & \multicolumn{2}{|c|}{ Treatments } & \multicolumn{2}{c|}{ Treatments } \\
\cline { 2 - 5 } & Unlimed & To be Limed & Unlimed & Limed \\
\hline O & $54 \pm 3.0$ & $68 \pm 3.0^{\#}$ & $58 \pm 3.0^{\mathrm{U}}$ & $35 \pm 3.0^{\# \mathrm{~L}}$ \\
\hline A & $17 \pm 2.0$ & $18 \pm 2.0$ & $14 \pm 1.0^{\mathrm{U}}$ & $11 \pm 1.0^{\# \mathrm{~L}}$ \\
\hline B & $8 \pm 0.8$ & $9 \pm 0.8$ & $7 \pm 0.5^{\mathrm{U}}$ & $7 \pm 0.5$ \\
\hline
\end{tabular}

The violin plots of this OM data show wide ranges in the O horizons (taller forms) with much flatter and consistent values in A and B horizons. There are a few high values particularly in the 2009 To Be Limed sites in A and B horizons.

Figure 14. Violin plot of \% OM from both treatments in 2009 and 2019 showing the OM differences between the years, treatments, and soil horizons as indicated in Table 6 (see description in Figure 11). 


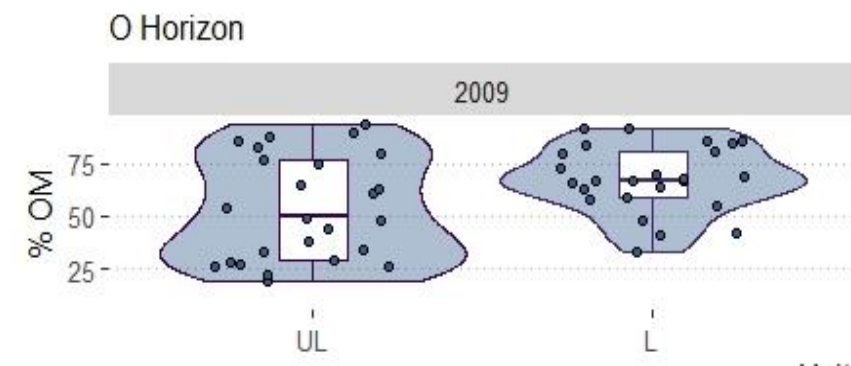

Unit Pairs

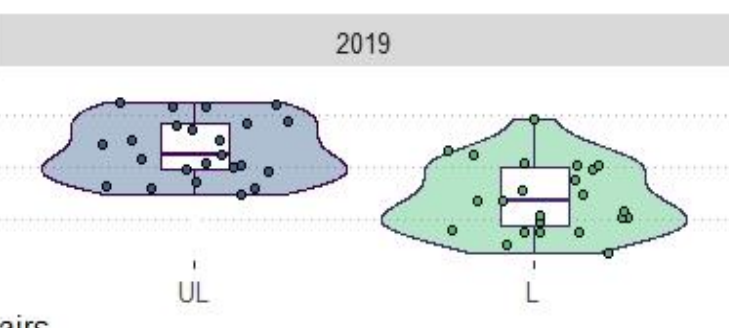

A Horizon

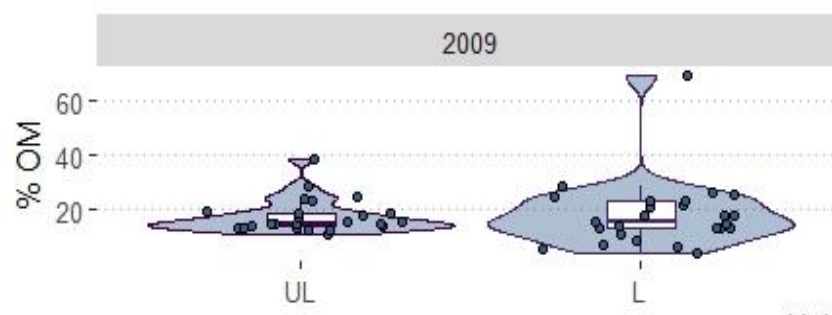

Unit Pairs

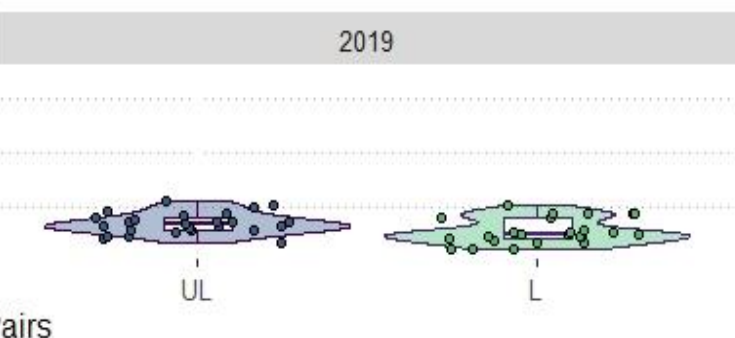

B Horizon

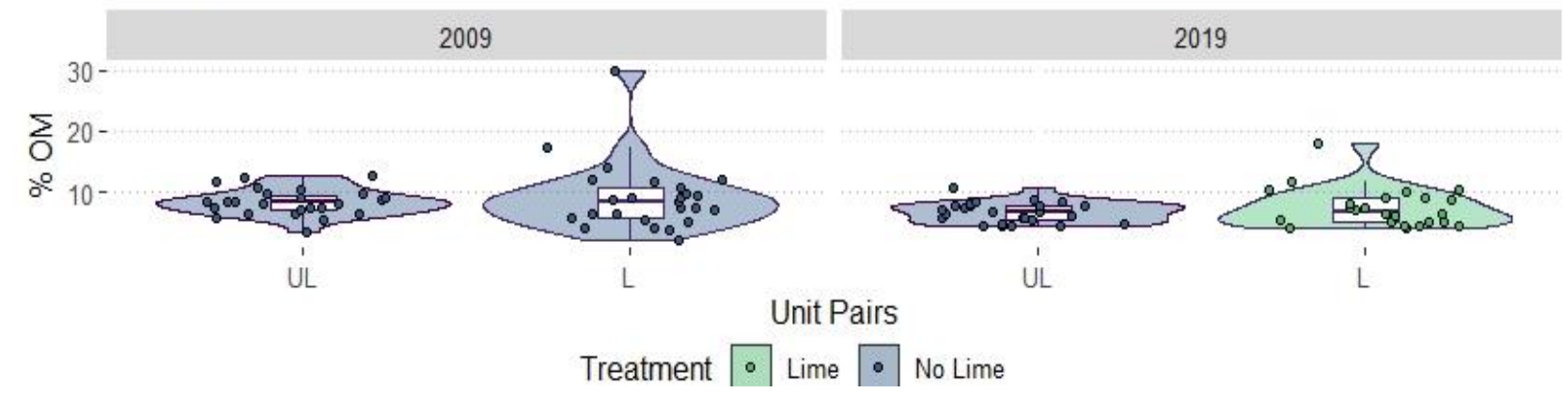

\section{$4.5 \%$ TC}

The \% TC levels of organic material in acid forest soils in Appalachia range from 25 to 27\% (Adams et al., 2006). The A and B horizons show lower \% TC values from 2 to 7\%. In our study, O horizons in 2009 averaged 28 and 36\% TC for the Unlimed and the To Be Limed sites (28 vs 36 \#, Table 7). For the Unlimed sites in 2009 vs 2019, \% TC was found to be similar (28 vs 31). The To Be Limed sites in 2009 and the Unlimed sites in 2019 were both significantly higher in \% TC than the 2019 Limed sites (36 and 31 vs 20 \# L); showing that the decrease of \% TC levels in the Limed 2019 sites could be related with the decomposition and decrease of \% OM shown in section 4.4. 
Total Carbon values in A horizons in 2009 did not vary, but the To Be Limed sites in 2009 and Unlimed sites in 2019 were significantly higher than the Limed sites in 2019 (Table 7). Values in B horizons showed almost no differences ranging from 2 to $4 \%$ There was a clear trend of higher to lower \%TC from the O to B horizons.

Table 7. Average \% TC values (\%) in O, A, and B horizons for sites sampled in the Terrestrial Liming Project. See footnotes in Table 3 for letter and symbol descriptions.

\begin{tabular}{|c|c|c|c|c|}
\hline Average \% TC & \multicolumn{2}{|c|}{2009} & \multicolumn{2}{c|}{2019} \\
\hline \multirow{2}{*}{ Horizon } & \multicolumn{2}{|c|}{ Treatments } & \multicolumn{2}{c|}{ Treatments } \\
\cline { 2 - 5 } & Unlimed & To be Limed & Unlimed & Limed \\
\hline O & $28 \pm 2.0$ & $36 \pm 2.0^{\#}$ & $31 \pm 1.0$ & $20 \pm 1.0^{\# \mathrm{~L}}$ \\
\hline A & $9 \pm 1.0$ & $10 \pm 1.0$ & $7 \pm 0.4^{U}$ & $6 \pm 0.4^{\# \mathrm{~L}}$ \\
\hline B & $3 \pm 0.4$ & $4 \pm 0.4$ & $2 \pm 0.2^{U}$ & $3 \pm 0.2^{\#}$ \\
\hline
\end{tabular}

Violin plots of \% TC (Figure 15) showed similar forms as those of \% OM in Figure 14. Taller forms representing a wider range of values was clearly shown in the O horizon and much flatter forms and lower values in A and B horizons. And as described above, there were a few high outlying values in the 2009 To Be Limed sites.

Figure 15. Violin plot of \% TC from both treatments in 2009 and 2019 showing the TC (\%) differences between the years, treatments, and soil horizons as indicated in Table 7 (see description in Figure 11). 


\section{O Horizon}

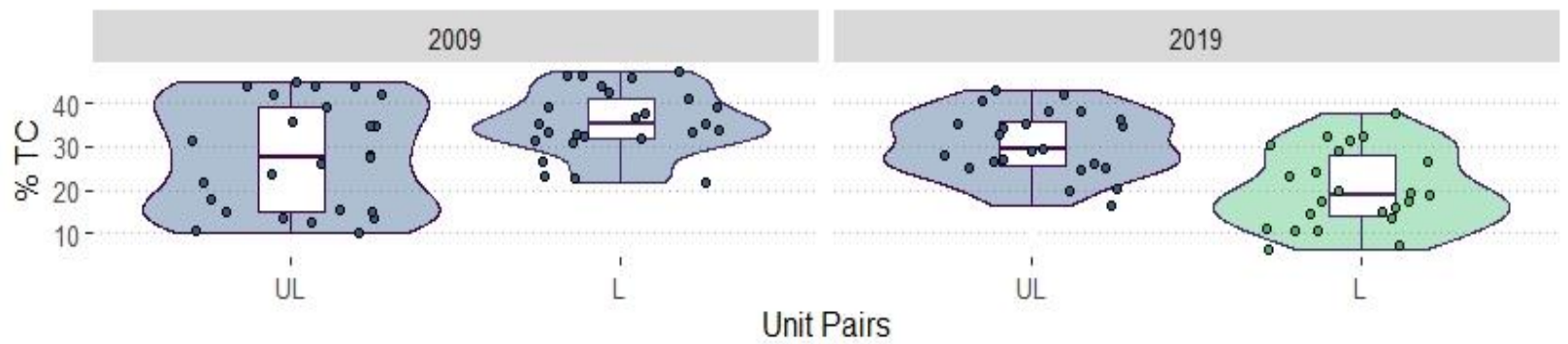

A Horizon

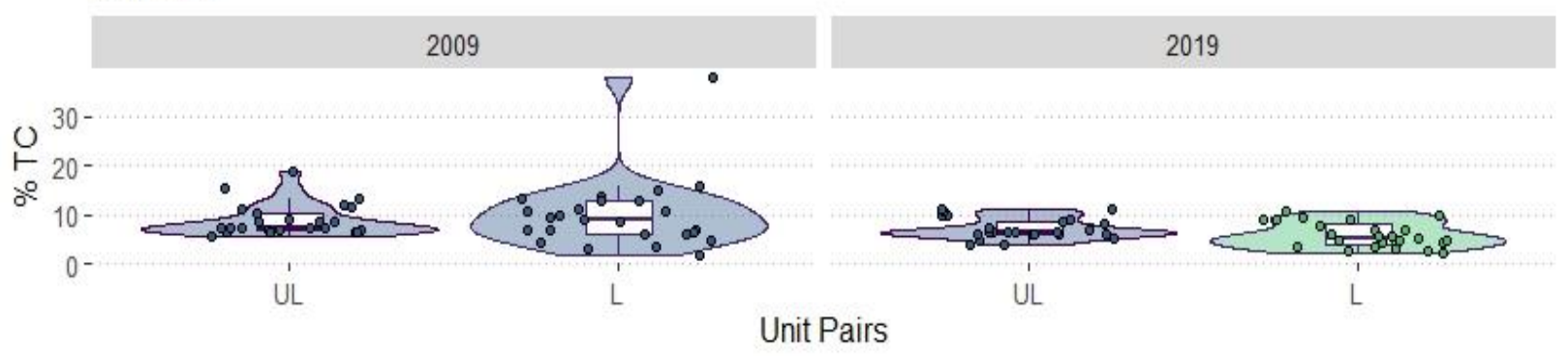

B Horizon

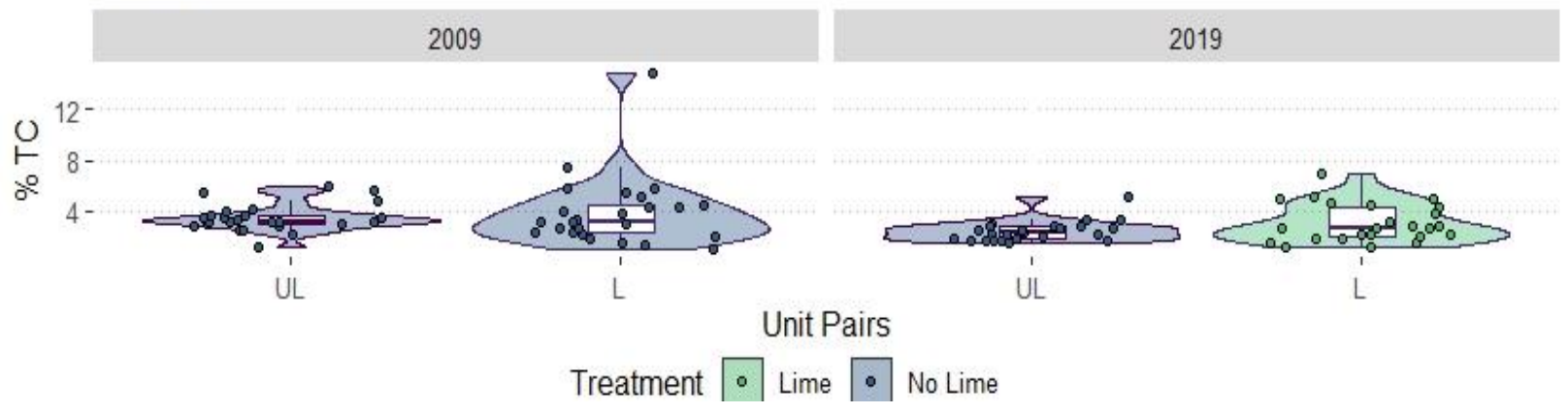

\section{$4.6 \% \mathrm{TN}$}

The \% TN levels of organic material in acid forest soils in Appalachia range from 1.0 to 1.4\% (Adams et al., 2006). The A and B horizons have lower \% TN values from 0.1 to $0.4 \%$. In our study, O horizons in 2009 averaged 1.4 and $2.0 \%$ TN for the Unlimed and the To Be Limed sites (Table 8). For the Unlimed treatments in 2009 vs 2019, \% TN was not significantly different and the To Be Limed sites in 2009 and the Unlimed sites in 2019 were found to be statistically different in \% TN than the 2019 Limed sites (2.0 and 1.5 vs 1.0 \# L).

Total Nitrogen values in A horizons mirrored the trends in the $\mathrm{O}$ horizon (Table 8); sites in 2009 did not vary in average values and the To Be Limed sites in 2009 and Unlimed sites in 2019 were significantly different than the Limed sites in 2019. The values in B horizons showed 
little difference across treatments and years. Total nitrogen was five to ten times higher in the $\mathrm{O}$ and $\mathrm{A}$ horizons than $\mathrm{B}$ horizons.

Table 8. Average \% TN values (\%) in O, A, and B horizons for sites sampled in the Terrestrial Liming Project. See footnotes in Table 3 for letter and symbol descriptions.

\begin{tabular}{|c|c|c|c|c|}
\hline Average \% TN & \multicolumn{2}{|c|}{2009} & \multicolumn{2}{c|}{2019} \\
\hline \multirow{2}{*}{ Horizon } & \multicolumn{2}{|c|}{ Treatments } & \multicolumn{2}{c|}{ Treatments } \\
\cline { 2 - 5 } & Unlimed & To be Limed & Unlimed & Limed \\
\hline O & $1.4 \pm 0.08$ & $2.0 \pm 0.08^{\#}$ & $1.5 \pm 0.07$ & $1.0 \pm 0.07^{\# \mathrm{~L}}$ \\
\hline $\mathrm{A}$ & $0.5 \pm 0.05$ & $0.5 \pm 0.05$ & $0.4 \pm 0.02^{\mathrm{U}}$ & $0.3 \pm 0.02^{\# \mathrm{~L}}$ \\
\hline $\mathrm{B}$ & $0.2 \pm 0.02$ & $0.2 \pm 0.02$ & $0.1 \pm 0.01^{\mathrm{U}}$ & $0.2 \pm 0.01^{\mathrm{L}}$ \\
\hline
\end{tabular}

Violin plots of \% TN (Figure 16) were almost identical to the plots of \% TC in Figure 15. Taller forms representing more variation in values were apparent in O horizons compared to $\mathrm{A}$ and B horizons.

Figure 16. Violin Plot of \% TN from both treatments in 2009 and 2019 showing the TN (\%) differences between the years, treatments, and soil horizons as indicated in Table 8 (see description in Figure 11). 

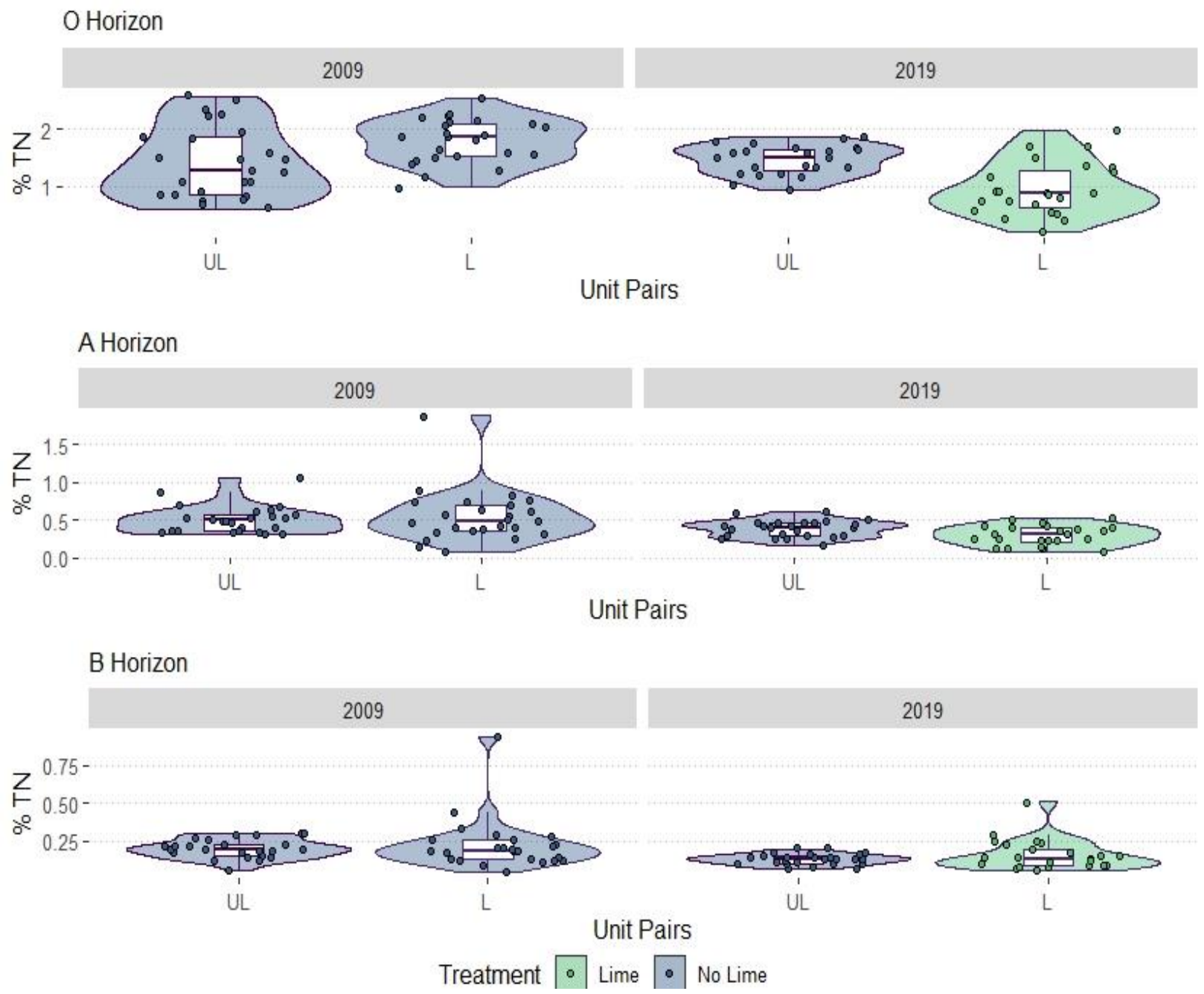

\subsection{P}

The phosphorus (P) values of organic material in acid forest soils in Appalachia range from 80 to $140 \mathrm{mg} / \mathrm{kg}$ (Pabian et al., 2012b; Dukes et al., 2020). The A and B horizons showed much lower P values from 6.0 to $15 \mathrm{mg} / \mathrm{kg}$. In our study, O horizons in 2009 averaged 56 and 72 $\mathrm{mg} / \mathrm{kg}$ for the Unlimed and the To Be Limed sites (Table 9). For the Unlimed treatments, P levels were significantly lower in 2009 vs 2019 (56 vs 69 U). The To Be Limed sites in 2009 and the Unlimed sites in 2019 were both significantly higher in P levels than the 2019 Limed sites (72 and 69 vs 49 \# ᄂ).

The phosphorus values in A horizons were ten times lower than in $\mathrm{O}$ horizons and the 2019 sites were both significantly lower in P than the 2009 sites (Table 9). The P levels in B 
horizons showed almost no differences with average totals ranging from 2 to $3 \mathrm{mg} / \mathrm{kg}$. As mentioned, $\mathrm{P}$ values were ten times higher in $\mathrm{O}$ horizons compared to $\mathrm{A}$ horizons and 20 times higher than B horizons.

Table 9. Average $P$ values $(\mathrm{mg} / \mathrm{kg}$ ) in $\mathrm{O}, \mathrm{A}$, and $B$ horizons for sites sampled in the Terrestrial Liming Project. See footnotes in Table 3 for letter and symbol descriptions.

\begin{tabular}{|c|c|c|c|c|}
\hline \multirow{2}{*}{ Average P } & \multicolumn{2}{|c|}{2009} & \multicolumn{2}{c|}{2019} \\
\hline \multirow{2}{*}{ Horizon } & \multicolumn{2}{|c|}{ Treatments } & \multicolumn{2}{c|}{ Treatments } \\
\cline { 2 - 5 } & Unlimed & To be Limed & Unlimed & Limed \\
\hline O & $56 \pm 6$ & $72 \pm 6^{\#}$ & $69 \pm 10^{\mathrm{U}}$ & $49 \pm 10^{\# \mathrm{~L}}$ \\
\hline $\mathrm{A}$ & $6 \pm 0.5$ & $6 \pm 0.5$ & $4 \pm 0.3^{\mathrm{U}}$ & $3 \pm 0.3^{\mathrm{L}}$ \\
\hline $\mathrm{B}$ & $2 \pm 0.2$ & $3 \pm 0.2$ & $2 \pm 0.1$ & $2 \pm 0.1^{\mathrm{L}}$ \\
\hline
\end{tabular}

Violin plots for P showed a distinct trend. The forms for most sites in 2009 and 2019 showed large variation (taller), while the forms for the 2019 Limed sites were more flattened except for some outliers (Figure 17).

Figure 17. Violin plot of $P$ from both treatments in 2009 and 2019 showing the $P(\mathrm{mg} / \mathrm{kg})$ differences between the years, treatments, and soil horizons as indicated in Table 9 (see description in Figure 11). 


\section{O Horizon}

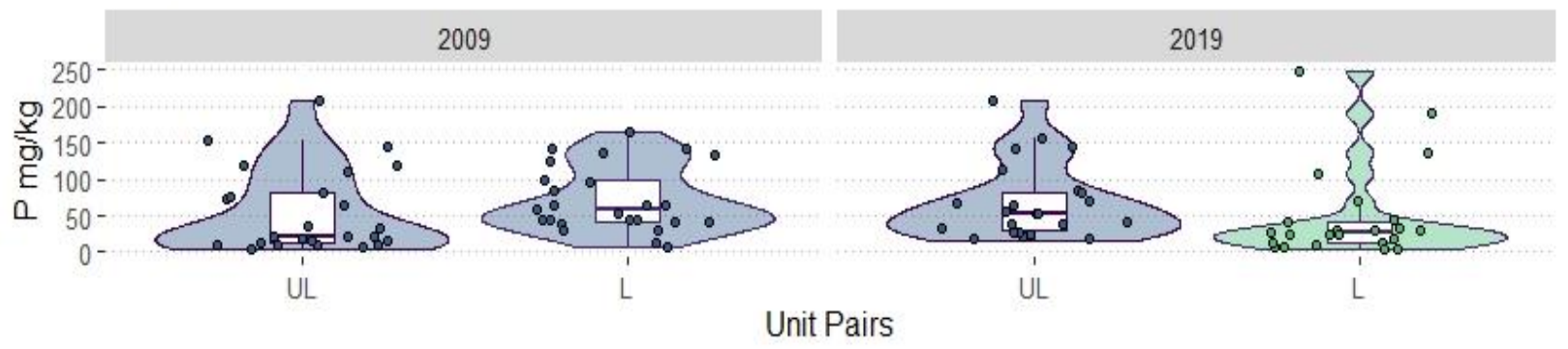

A Horizon

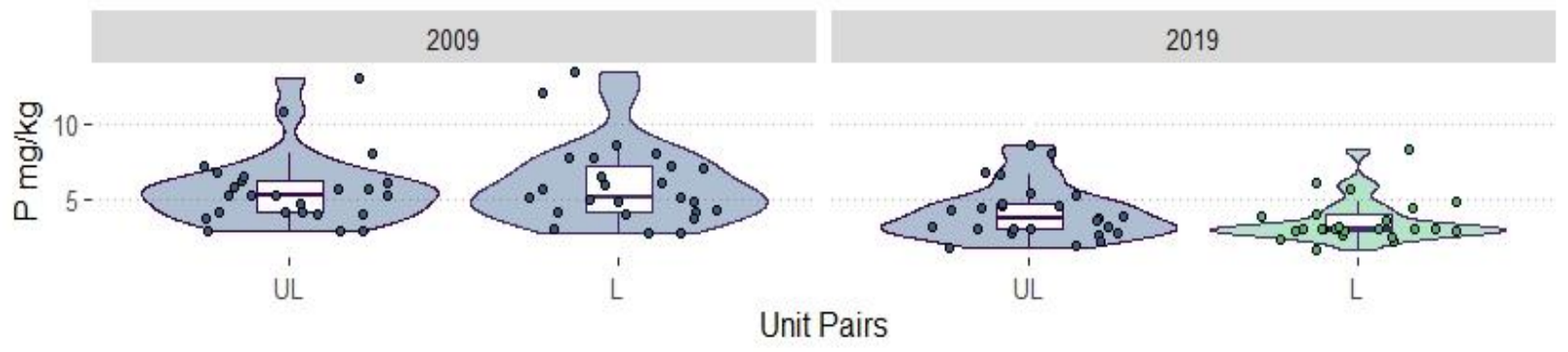

B Horizon

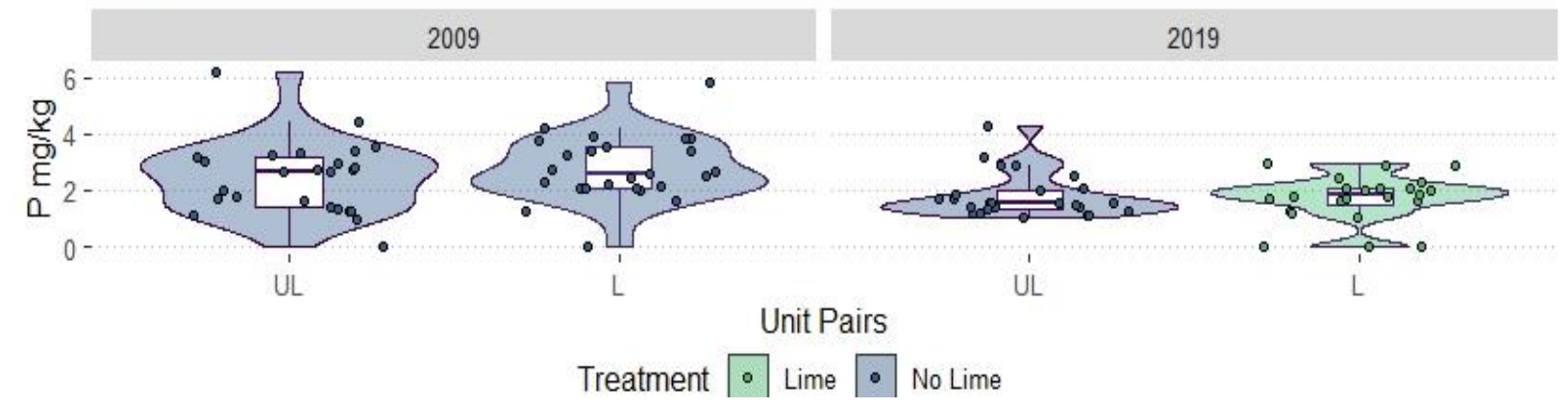

\section{$4.8 \mathrm{~K}$}

The potassium (K) levels of organic material in acid forest soils in Appalachia range from 0.20 to $0.21 \mathrm{cmol}^{+} / \mathrm{kg}$ (Farr et al., 2009). The A and B horizons show lower $\mathrm{K}$ levels from 0.08 to $0.20 \mathrm{cmol}^{+} / \mathrm{kg}$. In our study, O horizons in 2009 averaged 1.5 and $2.0 \mathrm{cmol}^{+} / \mathrm{kg}$ for the Unlimed and the To Be Limed sites (Table 10). For the Unlimed treatments in 2009 vs 2019, K levels were similar. The To Be Limed sites in 2009 and the Unlimed sites in 2019 were both significantly higher in $\mathrm{K}$ levels than the 2019 Limed sites (2.0 and 1.3 vs 1.0 \# L).

The $\mathrm{K}$ levels in A horizons were five times lower than O horizons (Table 10). Sites in 2009 did not vary in average values, but the $\mathrm{K}$ levels were significantly higher for the 2009 To be Limed vs 2019 Limed sites. The K values in B horizons were very similar ranging from 0.12 to 
$0.14 \mathrm{cmol}+/ \mathrm{kg}$ (Table 10). Values of $\mathrm{K}$ in $\mathrm{O}$ horizons were five times higher than $\mathrm{A}$ horizons and ten times higher than $\mathrm{B}$ horizons.

Table 10. Average $\mathrm{K}$ values $(\mathrm{cmol}+/ \mathrm{kg}$ ) in $\mathrm{O}, \mathrm{A}$, and $\mathrm{B}$ horizons for sites sampled in the Terrestrial Liming Project. See footnotes in Table 3 for letter and symbol descriptions.

\begin{tabular}{|c|c|c|c|c|}
\hline Average K & \multicolumn{2}{|c|}{2009} & \multicolumn{2}{c|}{2019} \\
\hline \multirow{2}{*}{ Horizon } & \multicolumn{2}{|c|}{ Treatments } & \multicolumn{2}{c|}{ Treatments } \\
\cline { 2 - 5 } & Unlimed & To be Limed & Unlimed & Limed \\
\hline O & $1.5 \pm 0.15$ & $2.0 \pm 0.15$ & $1.3 \pm 0.05$ & $1.0 \pm 0.05^{\text {\# }}$ \\
\hline A & $0.29 \pm 0.023$ & $0.28 \pm 0.023$ & $0.25 \pm 0.021$ & $0.19 \pm 0.0211^{\mathrm{L}}$ \\
\hline B & $0.14 \pm 0.008$ & $0.12 \pm 0.008$ & $0.12 \pm 0.010$ & $0.14 \pm 0.010$ \\
\hline
\end{tabular}

Violin plots of K (Figure 18) show taller forms in 2009 compared to 2019. K values were more similar (flatter) for the 2019 Limed sites.

Figure 18. Violin plot of $\mathrm{K}$ from both treatments in 2009 and 2019 showing the $\mathrm{K}(\mathrm{cmol}+/ \mathrm{kg})$ differences between the years, treatments, and soil horizons as indicated in Table 10 (see description in Figure 11). 

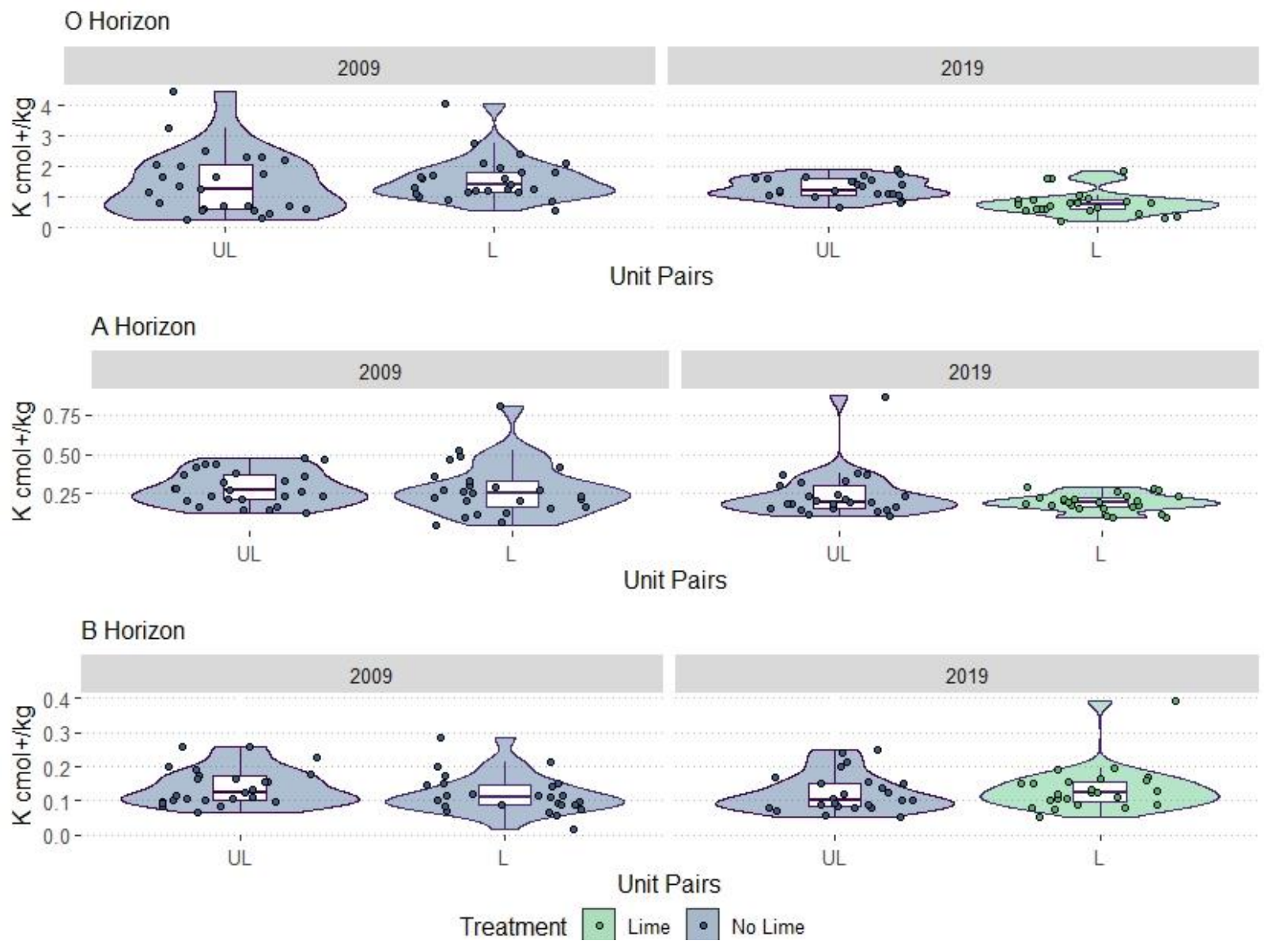

\section{$4.9 \mathrm{Ca}$}

In this project, Ca was chosen as an indicator of the level of success in liming these soils in the MNF. If significantly higher levels of Ca were found in the $\mathrm{O}$ and $\mathrm{A}$ horizons of Limed sites, the project would be deemed a success. Further sampling over time will help determine the longevity of the liming effects.

The Ca levels of organic material in acid forest soils in Appalachia range from 1.1 to 9.4 $\mathrm{cmol}^{+} / \mathrm{kg}$ (Farr et al., 2009; Kogelmann and Sharpe., 2006; Bailey et al., 2005; Drohan and Sharpe., 1997). The A and B horizons show lower Ca levels from 0.14 to $4.4 \mathrm{cmol}^{+} / \mathrm{kg}$. In our study, O horizons in 2009 averaged 9.1 and $9.3 \mathrm{cmol}^{+} / \mathrm{kg}$ for the Unlimed and the To Be Limed sites (Table 11). For the Unlimed treatments in 2009 vs 2019, Ca levels were 9.3 and 7.9 $\mathrm{cmol}+/ \mathrm{kg}$, respectively, and were not statistically different. The To Be Limed sites in 2009 and the Unlimed sites in 2019 were both significantly lower in Ca levels than the 2019 Limed sites 
(9.1 and 7.9 vs 27.2 \# L). Average Ca levels were three times higher between Unlimed and Limed sites in 2019 (7.9 and $\left.27.2{ }^{\#}\right)$.

The Ca levels in A horizons were four to ten times lower compared to O horizons (Table 27). Sites in 2009 did not vary in average values (0.9 and 0.7). For the Unlimed treatments in 2009 vs 2019, Ca levels were statistically higher in 2009 vs 2019 (0.7 vs 0.5 U). Also, the To Be Limed sites in 2009 and the Unlimed treatments in 2019 were significantly lower in Ca levels than the 2019 Limed sites (0.7 and 0.5 vs 3.2 \# $)$. The Ca levels in B horizons were four to five times lower than A horizons. The To Be Limed Ca levels in 2009 and also the Unlimed sites in 2019 were both significantly lower than 2019 Limed sites $\left(0.2\right.$ and 0.1 vs $\left.0.4{ }^{\# L}\right)$ just like the $A$ horizon (Table 11).

Table 11. Average Ca values ( $\mathrm{cmol}+/ \mathrm{kg})$ in O horizons for sites sampled in the Terrestrial Liming Project. See footnotes in Table 3 for letter and symbol descriptions.

\begin{tabular}{|c|c|c|c|c|}
\hline Average Ca & \multicolumn{2}{|c|}{2009} & \multicolumn{2}{c|}{2019} \\
\hline \multirow{2}{*}{ Horizon } & \multicolumn{2}{|c|}{ Treatments } & \multicolumn{2}{c|}{ Treatments } \\
\cline { 2 - 5 } & Unlimed & To be Limed & Unlimed & Limed \\
\hline O & $9.3 \pm 0.76$ & $9.1 \pm 0.76$ & $7.9 \pm 1.30$ & $27.2 \pm 1.28^{\# \mathrm{~L}}$ \\
\hline $\mathrm{A}$ & $0.9 \pm 0.10$ & $0.7 \pm 0.10$ & $0.5 \pm 0.33^{\mathrm{U}}$ & $3.2 \pm 0.33^{\# \mathrm{~L}}$ \\
\hline $\mathrm{B}$ & $0.2 \pm 0.05$ & $0.2 \pm 0.05$ & $0.1 \pm 0.04$ & $0.4 \pm 0.04^{\# \mathrm{~L}}$ \\
\hline
\end{tabular}

Violin plots of Ca (Figure 19) are quite unique. The 2009 sites and 2019 Unlimed sites show similar flat and wide forms while, as noted above, the 2019 Limed sites have much higher variation and a wider range of values, giving a taller plot. This is further shown in the A horizon and continues into the $B$ horizon. The only conclusion we can reach is that lime particles found their way into the samples collected from the A and B horizons. It is inconceivable that Ca could have dissolved and infiltrated into those lower horizons. Further sampling at three and five years from liming will more clearly identify the liming effect on those two horizons.

Figure 19. Violin lot of Ca from both treatments in 2009 and 2019 showing the $\mathrm{Ca}(\mathrm{cmol}+/ \mathrm{kg})$ differences between the years, treatments, and soil horizons as indicated in Table 11 (see description in Figure 11). 


\section{O Horizon}

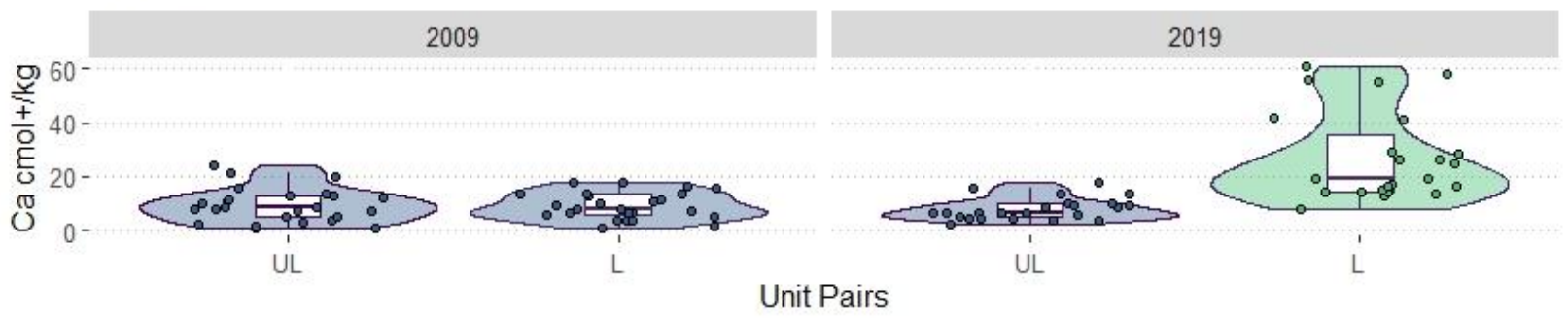

A Horizon

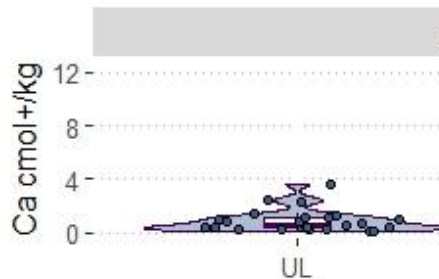

UL
2009

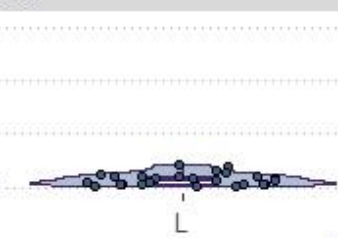

L

Unit Pairs

Unit Pairs

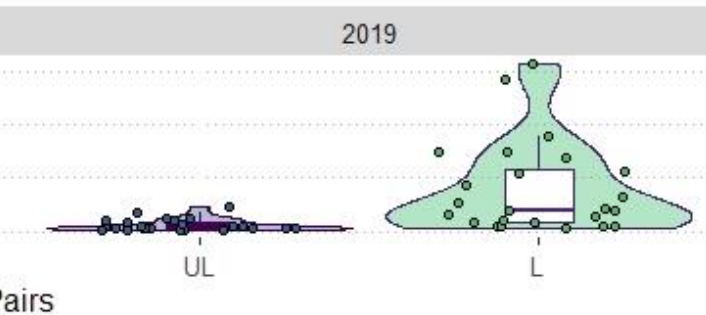

B Horizon

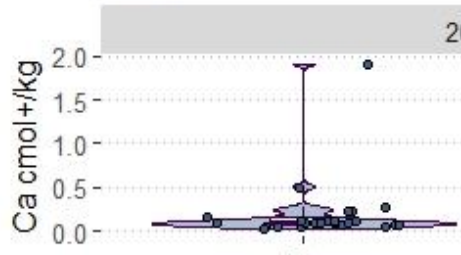

UL
2009

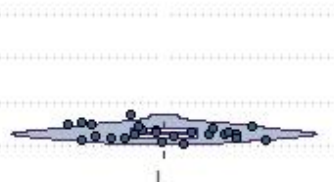

Unit Pairs

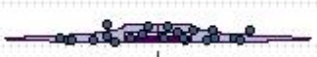

UL
2019

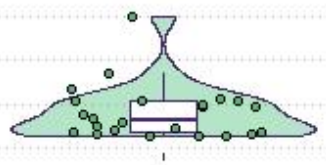

L

Treatment ${ }^{\circ}$ Lime $\bullet$ No Lime

\section{$4.10 \mathrm{Mg}$}

The Mg levels of organic material in acid forest soils in Appalachia range from 0.38 to $0.84 \mathrm{cmol}^{+} / \mathrm{kg}$ (Farr et al., 2009; Bailey et al. 2005; Kogelmann and Sharpe., 2006). The A and B horizons show lower Mg levels from 0.05 to $0.63 \mathrm{cmol}^{+} / \mathrm{kg}$. In our study, O horizons in 2009 averaged 1.8 and $2.0 \mathrm{cmol}^{+} / \mathrm{kg}$ for the Unlimed and the To Be Limed sites (Table 12).For the Unlimed treatments in 2009 vs $2019, \mathrm{Mg}$ levels were statistically different (1.8 vs $2.0 \mathrm{U}$ ). Since the material spread in this project contained only $3.3 \% \mathrm{Mg}$, we did not expect there to be a significant difference in $\mathrm{Mg}$ on Limed sites. The low levels and slower reaction of $\mathrm{Mg}(\mathrm{CO})_{3}$ than $\mathrm{Ca}(\mathrm{CO})_{3}$ suggested that there would be no effect of liming. Plus, the large sand-sized particle sizes were slower to react than pulverized limestone. The results for $\mathrm{Mg}$ showed no significant differences even though the average values were slightly higher for the 2019 Limed sites (2.0 vs 2.4). 
The Mg levels in A horizons showed no significant differences in any of the treatments or years (Table 12). The Mg levels in B horizons also showed little differences in values. There was a $95 \%$ decrease in values between the $O$ and $B$ horizons.

Table 12. Average $\mathrm{Mg}$ values $(\mathrm{cmol}+\mathrm{kg}$ ) in $\mathrm{O}, \mathrm{A}$, and $\mathrm{B}$ horizons for sites sampled in the Terrestrial Liming Project. See footnotes in Table 3 for letter and symbol descriptions.

\begin{tabular}{|c|c|c|c|c|}
\hline \multirow{2}{*}{ Average Mg } & \multicolumn{2}{|c|}{2009} & \multicolumn{2}{c|}{2019} \\
\hline \multirow{2}{*}{ Horizon } & \multicolumn{2}{|c|}{ Treatments } & \multicolumn{2}{c|}{ Treatments } \\
\cline { 2 - 5 } & Unlimed & To be Limed & Unlimed & Limed \\
\hline O & $1.8 \pm 0.13$ & $2.0 \pm 0.13$ & $2.0 \pm 0.23^{U}$ & $2.4 \pm 0.23$ \\
\hline A & $0.29 \pm 0.025$ & $0.30 \pm 0.025$ & $0.27 \pm 0.050$ & $0.38 \pm 0.050$ \\
\hline B & $0.1 \pm 0.008$ & $0.1 \pm 0.008$ & $0.08 \pm 0.008$ & $0.1 \pm 0.008^{\# \mathrm{~L}}$ \\
\hline
\end{tabular}

Violin plots of Mg values (Figure 20) showed similar forms as those for Ca except the magnitude of tallness was reduced. Outlying values were evident for the 2019 Limed sites.

Figure 20. Violin Plot of Mg from both treatments in 2009 and 2019 showing the $\mathrm{Mg}(\mathrm{cmol}+/ \mathrm{kg})$ differences between the years, treatments, and soil horizons as indicated in Table 12 (see description in Figure 11). 


\section{O Horizon}
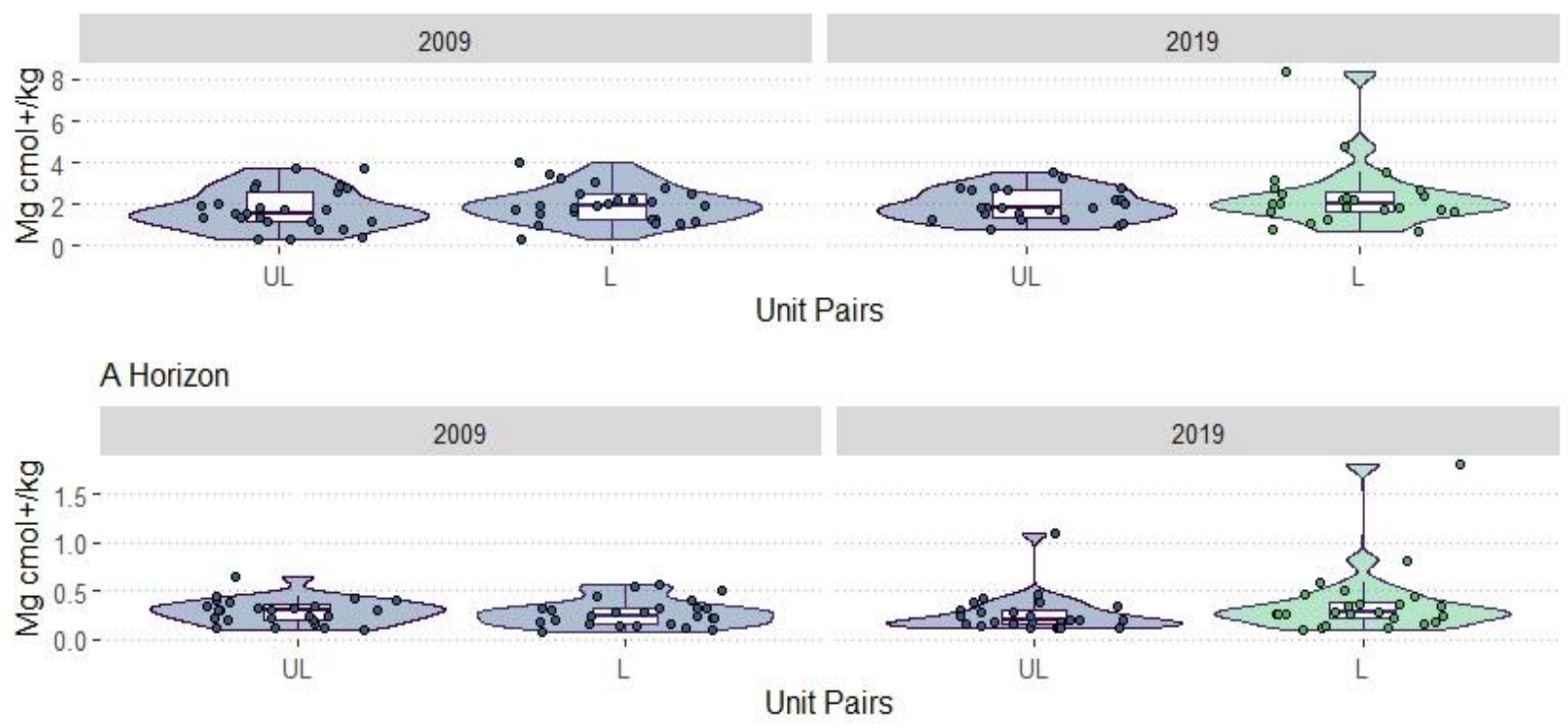

B Horizon

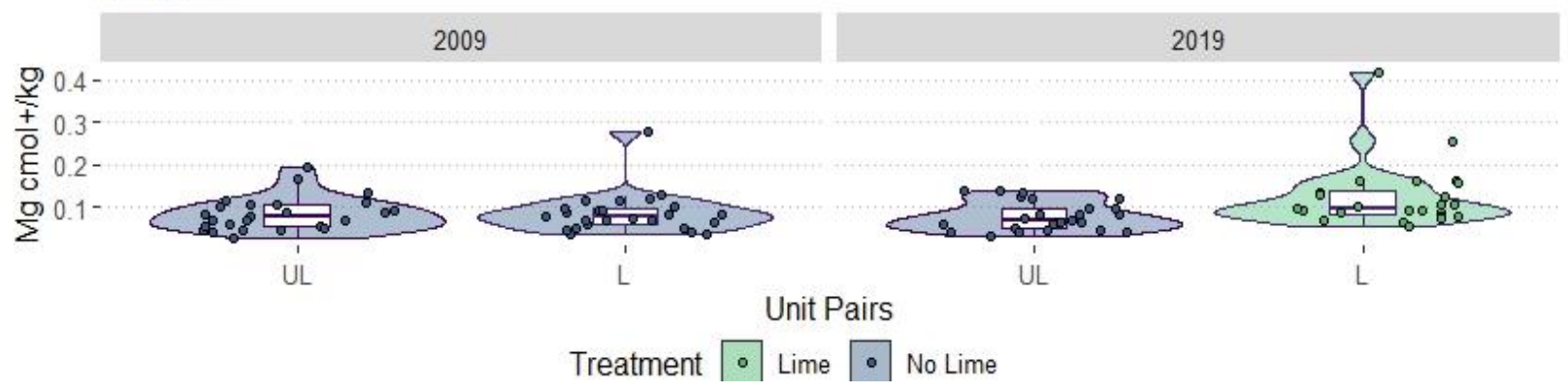

\section{$4.11 \mathrm{Na}$}

The Na levels of organic material in acid forest soils in Appalachia range from 0.03 to $0.05 \mathrm{cmol}^{+} / \mathrm{kg}$ (Farr et al., 2009). The A and B horizons show similar Na levels from 0.02 to 0.05 $\mathrm{cmol}^{+} / \mathrm{kg}$. In our study, O horizons in 2009 averaged 0.15 and $0.17 \mathrm{cmol}^{+} / \mathrm{kg}$ for the Unlimed and the To Be Limed sites (Table 13). Na concentrations were significantly lower in the 2019 Limed sites compared to the 2009 To Be Limed and 2019 Limed sites ( 0.17 and 0.13 vs 0.08 \# L).

The Na levels in A horizons mirrored the trends shown in O horizons, although the values were one-half the levels in the O horizon (Table 13). The Na levels in B horizons showed few differences. Levels of Na were similar in the A and B horizons, which were about three times less than the $\mathrm{O}$ horizon.

Table 13. Average Na values $(\mathrm{cmol}+/ \mathrm{kg})$ in O horizons for sites sampled in the Terrestrial Liming Project. See footnotes in Table 3 for letter and symbol descriptions. 


\begin{tabular}{|c|c|c|c|c|}
\hline Average Na & \multicolumn{2}{|c|}{2009} & \multicolumn{2}{c|}{2019} \\
\hline \multirow{2}{*}{ Horizon } & \multicolumn{2}{|c|}{ Treatments } & \multicolumn{2}{c|}{ Treatments } \\
\cline { 2 - 5 } & Unlimed & To be Limed & Unlimed & Limed \\
\hline $\mathrm{O}$ & $0.15 \pm 0.013$ & $0.17 \pm 0.013$ & $0.13 \pm 0.013$ & $0.08 \pm 0.013^{\# \mathrm{~L}}$ \\
\hline $\mathrm{A}$ & $0.1 \pm 0.01$ & $0.1 \pm 0.01$ & $0.04 \pm 0.004^{\mathrm{U}}$ & $0.03 \pm 0.004^{\mathrm{L}}$ \\
\hline $\mathrm{B}$ & $0.04 \pm 0.004$ & $0.04 \pm 0.004$ & $0.03 \pm 0.004$ & $0.02 \pm 0.004^{\mathrm{L}}$ \\
\hline
\end{tabular}

Violin plots of Na concentrations (Figure 21) showed some variation in the height of plots. Na variation in the $\mathrm{O}$ horizon appeared to be larger than the $\mathrm{A}$ and $\mathrm{B}$ horizons.

Figure 21. Violin plot of $\mathrm{Na}$ from both treatments in 2009 and 2019 showing the $\mathrm{Na}(\mathrm{cmol}+\mathrm{kg})$ differences between the years, treatments, and soil horizons as indicated in Table 13 (see description in Figure 11).
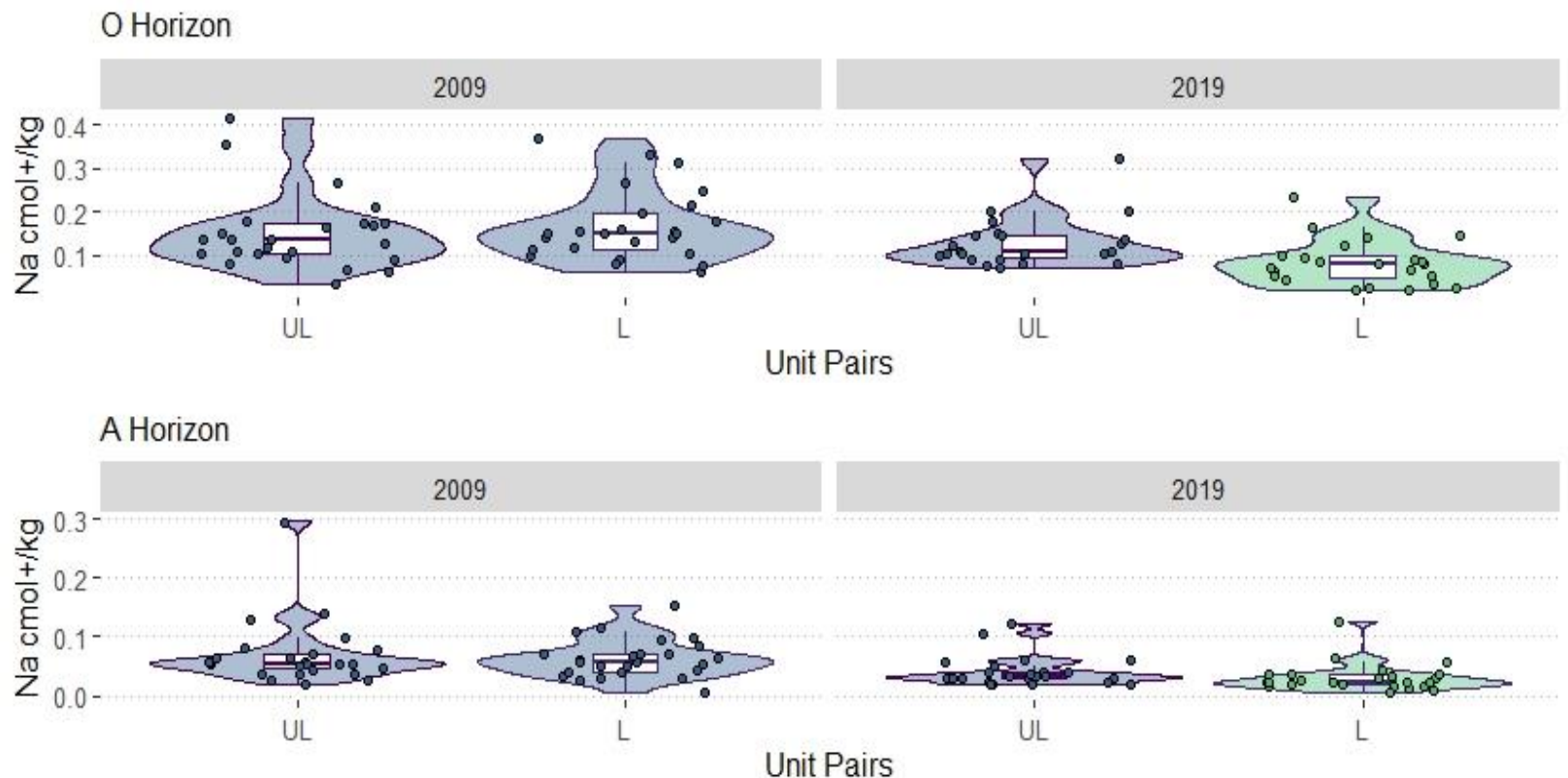

B Horizon

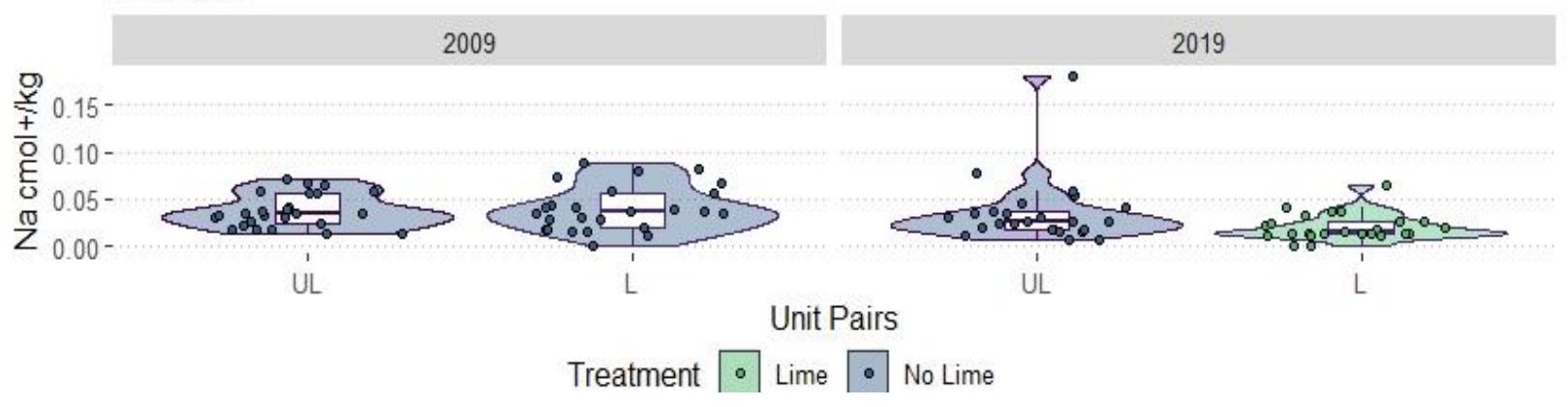




\subsection{Al}

Aluminum is another surrogate for acid levels and low pH in soils. As such, Al can also be a primary indicator of the level of success of a liming treatment. One of the main reasons for liming, aside from lowering $\mathrm{pH}$ and raising $\mathrm{Ca}$ levels, is to reduce Al concentrations to non-toxic levels.

The aluminum (Al) levels of organic material in acid forest soils in Appalachia range from 540 to $648 \mathrm{mg} / \mathrm{kg}$ (Farr et al., 2009). The A and B horizons show lower and similar Al levels from 324 to $612 \mathrm{mg} / \mathrm{kg}$. In our study, O horizons in 2009 averaged 272 and $275 \mathrm{mg} / \mathrm{kg}$ for the Unlimed and the To Be Limed sites (Table 14). For Unlimed treatments in 2009 vs 2019, Al levels were not statistically different (275 vs 261). The To Be Limed sites in 2009 and the Unlimed sites in 2019 were both significantly higher in Al levels than the 2019 Limed sites ( 272 and 261 vs 58 \# ᄂ). These lower levels of Al confirm the effect of liming similarly as shown earlier with the higher concentrations of $\mathrm{Ca}$ and higher $\mathrm{pH}$ values.

The Al levels in A horizons were similar to the trends shown in O horizons; there were no significant differences for 2009 sites, and the 2019 Limed sites being significantly lower than the 2009 To Be Limed and the 2019 Unlimed sites ( 647 and 627 vs 325 \# L, Table 14). The average Al levels in B horizons were not different ranging from 461 to $506 \mathrm{mg} / \mathrm{kg}$ (Table 14). Al concentrations almost doubled from $\mathrm{O}$ to $\mathrm{B}$ horizons.

Table 14. Average Al values $(\mathrm{mg} / \mathrm{kg}$ ) in $\mathrm{O}, \mathrm{A}$, and B horizons for sites sampled in the Terrestrial Liming Project. See footnotes in Table 3 for letter and symbol descriptions.

\begin{tabular}{|c|c|c|c|c|}
\hline Average Al & \multicolumn{2}{|c|}{2009} & \multicolumn{2}{c|}{2019} \\
\hline \multirow{2}{*}{ Horizon } & \multicolumn{2}{|c|}{ Treatments } & \multicolumn{2}{c|}{ Treatments } \\
\cline { 2 - 5 } & Unlimed & To be Limed & Unlimed & Limed \\
\hline O & $275 \pm 33$ & $272 \pm 33$ & $261 \pm 17$ & $58 \pm 17^{\# \mathrm{~L}}$ \\
\hline A & $584 \pm 44$ & $647 \pm 44$ & $627 \pm 31$ & $325 \pm 32^{\# \mathrm{~L}}$ \\
\hline B & $461 \pm 36$ & $510 \pm 36$ & $464 \pm 27$ & $506 \pm 28$ \\
\hline
\end{tabular}


Violin plots of Al (Figure 22) showed a wide range of values in all sites and treatments except for the $\mathrm{O}$ horizons of the 2019 Limed sites. This form is one of the most flat (less variation) of any form shown.

Figure 22. Violin plot of Al from both treatments in 2009 and 2019 showing the $\mathrm{Al}(\mathrm{mg} / \mathrm{kg})$ differences between the years, treatments, and soil horizons as indicated in Table 14 (see description in Figure 11).
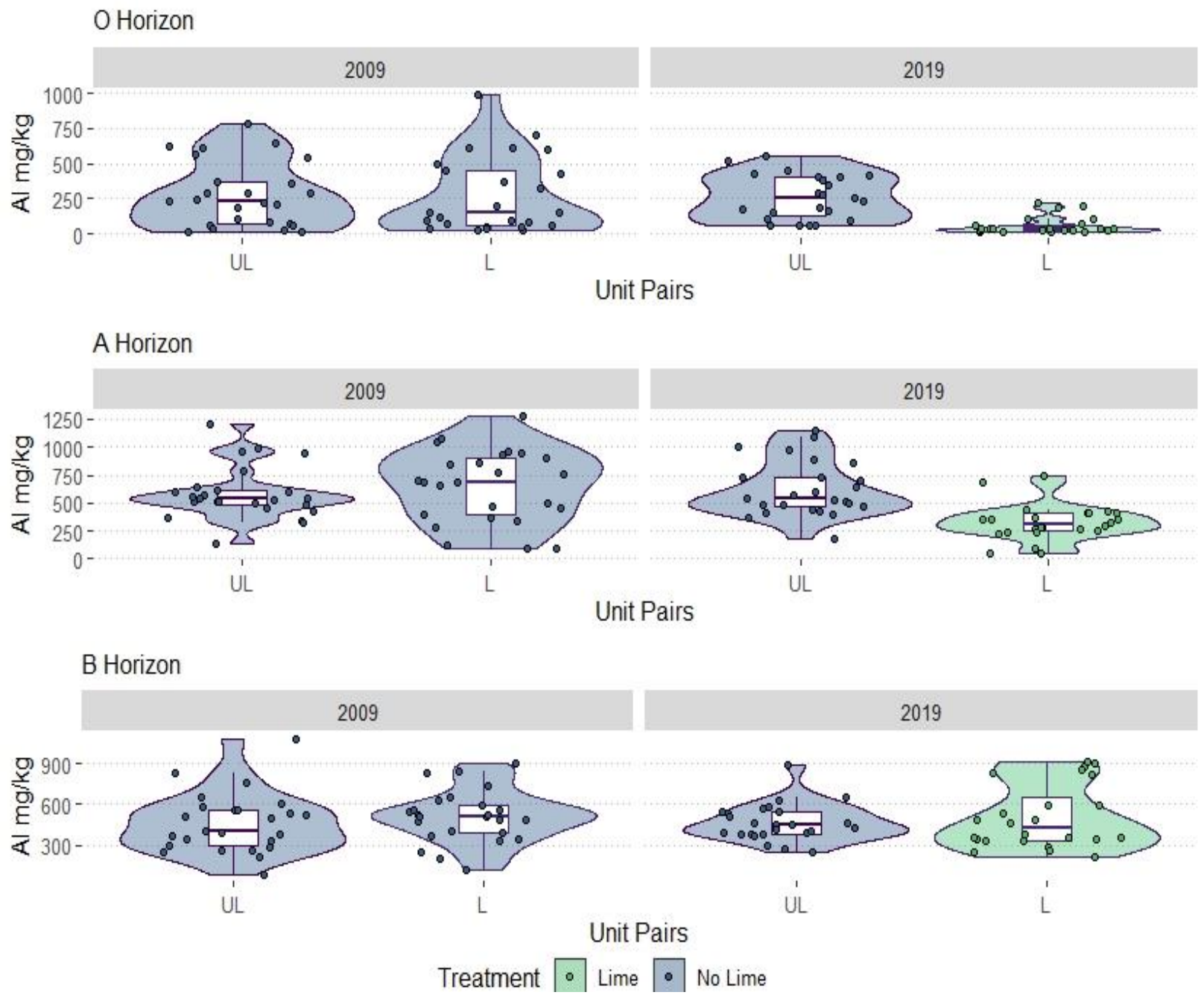


\subsection{Fe}

In this area of humid and acid-forming parent materials, the soils generally have high levels of $\mathrm{Al}$ and Fe. With liming, $\mathrm{Al}$ and Fe concentration changes should show similar trends due to the changes in $\mathrm{pH}$ with liming. The Fe levels of organic material in acid forest soils in Appalachia range from 9 to $960 \mathrm{mg} / \mathrm{kg}$ (Smith et al., 2013). The A and B horizons showed similar Fe levels from 50 to $900 \mathrm{mg} / \mathrm{kg}$. In our study, O horizons in 2009 averaged $25 \mathrm{mg} / \mathrm{kg}$ for both the Unlimed and the To Be Limed sites (Table 15). For the Unlimed treatments in 2009 vs 2019, Fe levels were statistically different as Fe levels almost doubled (25 vs 49 U). The To Be Limed sites in 2009 and the Unlimed sites in 2019 were both significantly higher in Fe levels than the 2019 Limed sites ( 25 and 49 vs 12 \# L), confirming the results shown above with Al.

The Fe levels in A horizons varied from 30 to $40 \mathrm{mg} / \mathrm{kg}$ in 2009 (Table 15). For the Unlimed sites in 2009 vs 2019, Fe levels significantly increased over the 10-year sampling period (30 vs $44 \mathrm{U}$ ). The Fe levels in B horizons showed similar values except for the 2019 Limed sites, which showed a doubling of Fe concentrations (Table 15). This is a curious result since all sites (not just one or two) showed increases of Fe and we cannot explain this apparent increase in Fe concentrations. Values for Fe were similar across all horizons.

Table 15. Average Fe values $(\mathrm{mg} / \mathrm{kg}$ ) in $\mathrm{O}, \mathrm{A}$, and $\mathrm{B}$ horizons for sites sampled in the Terrestrial Liming Project. See footnotes in Table 3 for letter and symbol descriptions.

\begin{tabular}{|c|c|c|c|c|}
\hline Average Fe & \multicolumn{2}{|c|}{2009} & \multicolumn{2}{c|}{2019} \\
\hline \multirow{2}{*}{ Horizon } & \multicolumn{2}{|c|}{ Treatments } & \multicolumn{2}{c|}{ Treatments } \\
\cline { 2 - 5 } & Unlimed & To be Limed & Unlimed & Limed \\
\hline O & $25 \pm 3$ & $25 \pm 3$ & $49 \pm 4^{U}$ & $12 \pm 4^{\# \mathrm{~L}}$ \\
\hline A & $30 \pm 5$ & $40 \pm 5$ & $44 \pm 5^{\mathrm{U}}$ & $29 \pm 5$ \\
\hline B & $11 \pm 3$ & $14 \pm 3$ & $14 \pm 3^{\mathrm{U}}$ & $28 \pm 3^{\# \mathrm{~L}}$ \\
\hline
\end{tabular}

Violin plots of Fe (Figure 23) showed a curious trend with tall forms representing high levels of variation (except for 2019 Limed sites), which tended to get shorter (less variation in values) with depth. 
Figure 23. Violin plot of Fe from both treatments in 2009 and 2019 showing the $\mathrm{Fe}(\mathrm{mg} / \mathrm{kg})$ differences between the years, treatments, and soil horizons as indicated in Table 15 (see description in Figure 11).
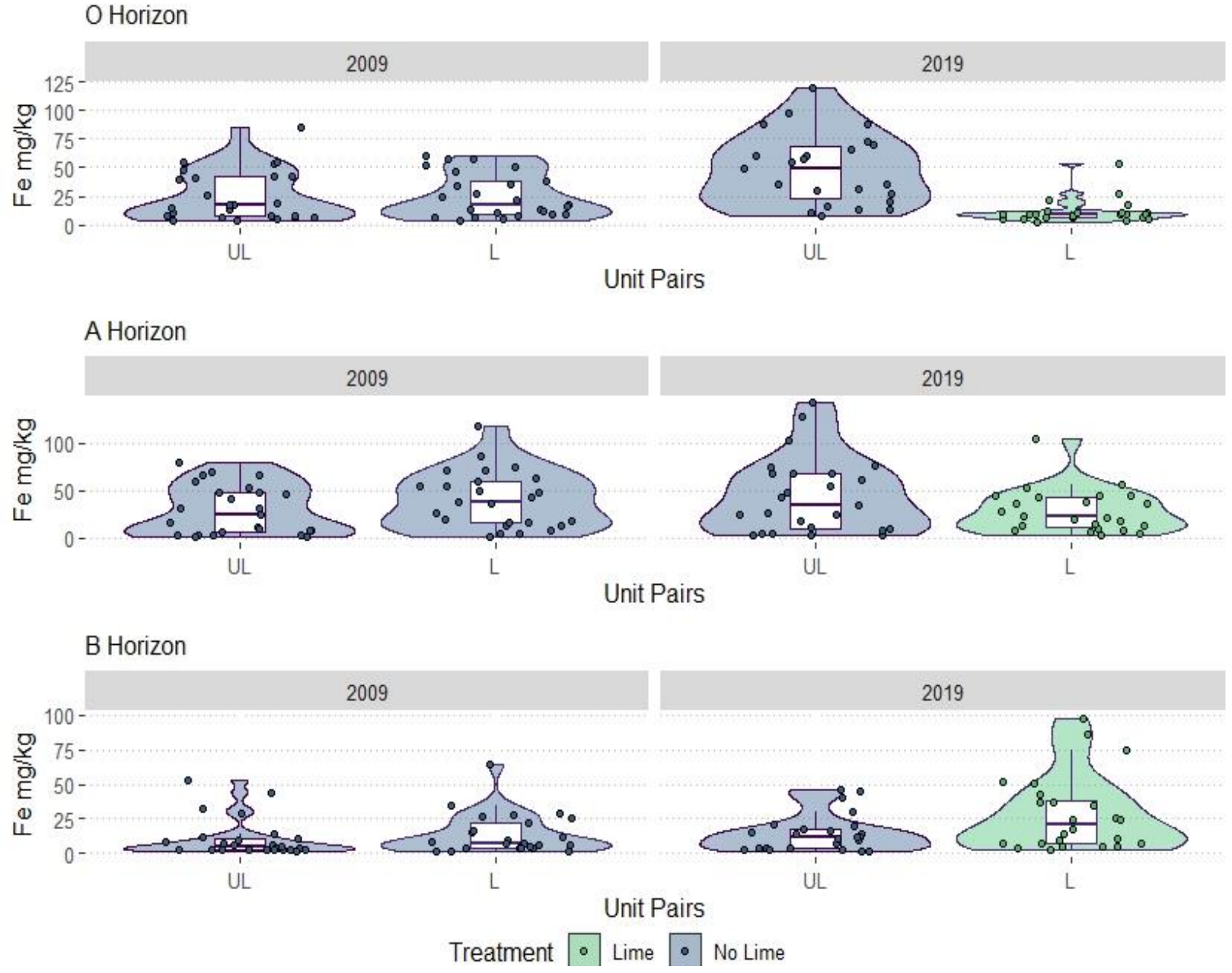

\subsection{Mn}

The Mn levels of organic material in acid forest soils in Appalachia range from 147 to $431 \mathrm{mg} / \mathrm{kg}$ (Kogelmann and Sharpe., 2016). The A and B horizons showed Mn levels from 4 to $172 \mathrm{mg} / \mathrm{kg}$. In our study, O horizons in 2009 averaged 310 and $454 \mathrm{mg} / \mathrm{kg}$ for the Unlimed and the To Be Limed sites (Table 16). For the Unlimed treatments in 2009 vs 2019, Mn levels were statistically different as $\mathrm{Mn}$ levels significantly increased over time (310 vs 512 U). The To Be Limed sites in 2009 and the Unlimed sites in 2019 were both significantly higher than Mn levels in the 2019 Limed sites (454 and 512 vs $397^{\# ~ L)}$ ). 
The average $\mathrm{Mn}$ levels in A horizons were not significantly different among treatments sites or years (range of 48 to $88 \mathrm{mg} / \mathrm{kg}$, Table 16). The Mn levels in B horizons also showed no differences among treatments or years. Manganese concentrations decreased more than 20 times from O (average of $420 \mathrm{mg} / \mathrm{kg}$ ) to B horizons (average of $16 \mathrm{mg} / \mathrm{kg}$ ).

Table 16. Average $\mathrm{Mn}$ values $(\mathrm{mg} / \mathrm{kg}$ ) in $\mathrm{O}, \mathrm{A}$, and B horizons for sites sampled in the Terrestrial Liming Project. See footnotes in Table 3 for letter and symbol descriptions.

\begin{tabular}{|c|c|c|c|c|}
\hline \multirow{2}{*}{ Average Mn } & \multicolumn{2}{|c|}{2009} & \multicolumn{2}{c|}{2019} \\
\hline \multirow{2}{*}{ Horizon } & \multicolumn{2}{|c|}{ Treatments } & \multicolumn{2}{c|}{ Treatments } \\
\cline { 2 - 5 } & Unlimed & To be Limed & Unlimed & Limed \\
\hline O & $310 \pm 36$ & $454 \pm 36$ & $512 \pm 53^{U}$ & $397 \pm 52^{\# \mathrm{~L}}$ \\
\hline $\mathrm{A}$ & $48 \pm 17$ & $59 \pm 17$ & $88 \pm 19$ & $64 \pm 20$ \\
\hline $\mathrm{B}$ & $10 \pm 3$ & $13 \pm 3$ & $19 \pm 8$ & $23 \pm 8$ \\
\hline
\end{tabular}

Violin plots of $\mathrm{Mn}$ (Figure 24) showed taller forms in O horizons with distinct outlying values stretching the forms. Very small variation among values within treatment and years gave some of the flattest forms of any element in this study.

Figure 24. Violin plot of $\mathrm{Mn}$ from both treatments in 2009 and 2019 showing the $\mathrm{Mn}(\mathrm{mg} / \mathrm{kg})$ differences between the years, treatments, and soil horizons as indicated in Table 16 (see description in Figure 11). 

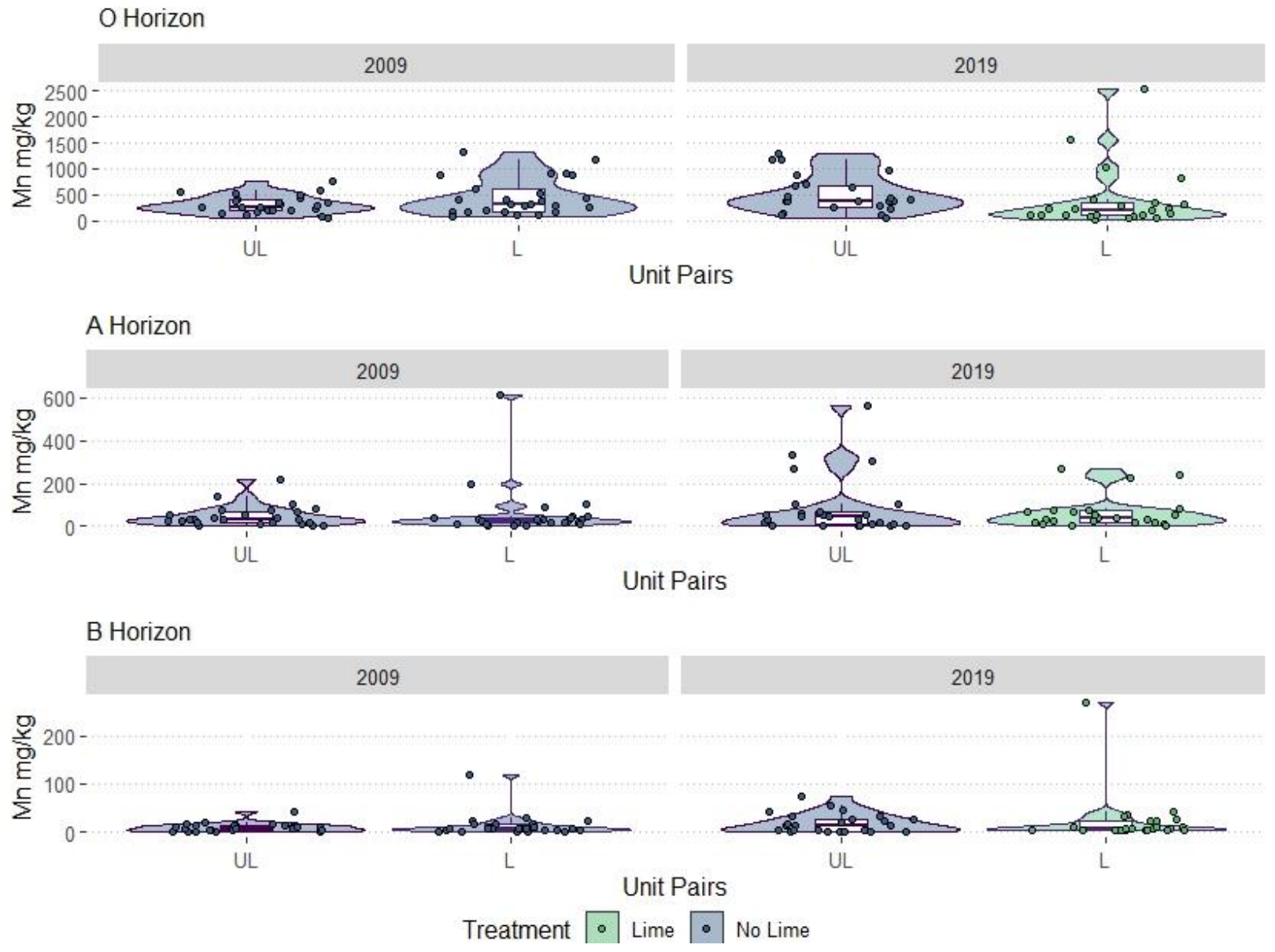

\section{$4.15 \mathrm{Zn}$}

The $\mathrm{Zn}$ levels of organic material in acid forest soils in Appalachia range from 1 to 344 $\mathrm{mg} / \mathrm{kg}$ (Smith et al., 2013). The A and B horizons showed similar but higher $\mathrm{Zn}$ levels from 1 to $1,440 \mathrm{mg} / \mathrm{kg}$. In our study, O horizons in 2009 averaged 15 and $17 \mathrm{mg} / \mathrm{kg}$ for the Unlimed and the To Be Limed sites (Table 17). For the Unlimed treatments in 2009 vs 2019, Zn levels were statistically different (15 vs 19 \#). The To Be Limed sites in 2009 and the Unlimed sites in 2019 were both significantly higher in Zn levels than the 2019 Limed sites (17 and 19 vs 5 \# L).

The $\mathrm{Zn}$ levels in A horizons showed only small variation and the 2019 Unlimed and Limed sites were significantly lower than their counterparts in 2009 (Table 17). The $\mathrm{Zn}$ levels in B horizons were not different for 2009 nor for 2019. The To Be Limed sites in 2009 were statistically different in Zn levels than the 2019 Limed sites (1.5 vs $1.0^{L}$, Table 17). 
Table 17. Average $\mathrm{Zn}$ values $(\mathrm{mg} / \mathrm{kg}$ ) in $\mathrm{O}, \mathrm{A}$, and B horizons for sites sampled in the Terrestrial Liming Project. See footnotes in Table 3 for letter and symbol descriptions.

\begin{tabular}{|c|c|c|c|c|}
\hline \multirow{2}{*}{ Average Zn } & \multicolumn{2}{|c|}{2009} & \multicolumn{2}{c|}{2019} \\
\hline \multirow{2}{*}{ Horizon } & \multicolumn{2}{|c|}{ Treatments } & \multicolumn{2}{c|}{ Treatments } \\
\cline { 2 - 5 } & Unlimed & To be Limed & Unlimed & Limed \\
\hline O & $15 \pm 1$ & $17 \pm 1$ & $19 \pm 1^{\mathrm{U}}$ & $5 \pm 1^{\# \mathrm{~L}}$ \\
\hline $\mathrm{A}$ & $4.8 \pm 0.82$ & $3.8 \pm 0.82$ & $3.1 \pm 0.36^{\mathrm{U}}$ & $2.2 \pm 0.37^{\mathrm{L}}$ \\
\hline $\mathrm{B}$ & $1.1 \pm 0.14$ & $1.5 \pm 0.14$ & $1.0 \pm 0.09$ & $1.0 \pm 0.09^{\mathrm{L}}$ \\
\hline
\end{tabular}

Violin plots of Zn (Figure 25) were quite distinct with tall forms for O horizons and less variation for $\mathrm{A}$ and $\mathrm{B}$ horizons.

Figure 25. Violin plot of Zn from both treatments in 2009 and 2019 showing the $\mathrm{Zn}(\mathrm{mg} / \mathrm{kg})$ differences between the years, treatments, and soil horizons as indicated in Table 17 (see description in Figure 11). 


\section{O Horizon}

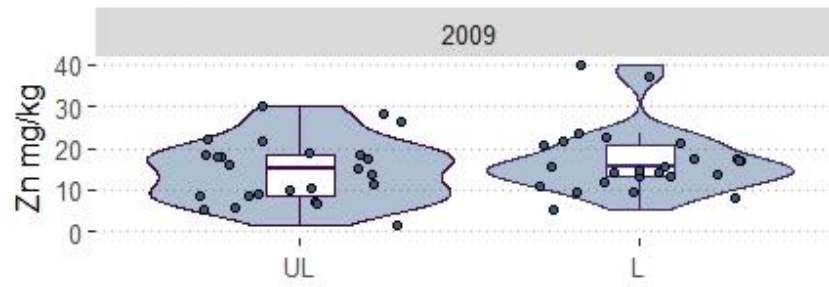

Unit Pairs

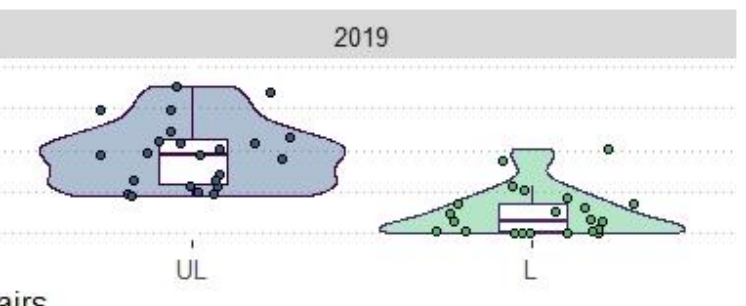

A Horizon

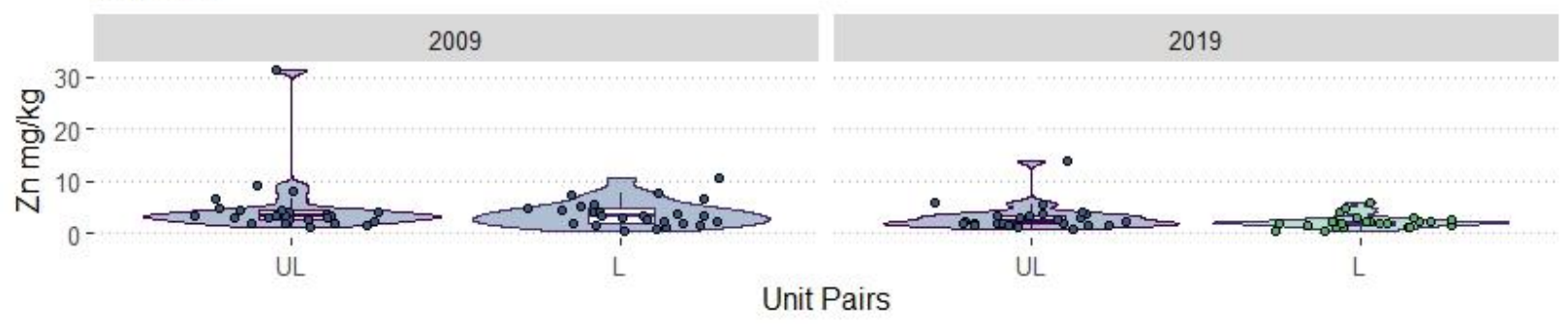

B Horizon

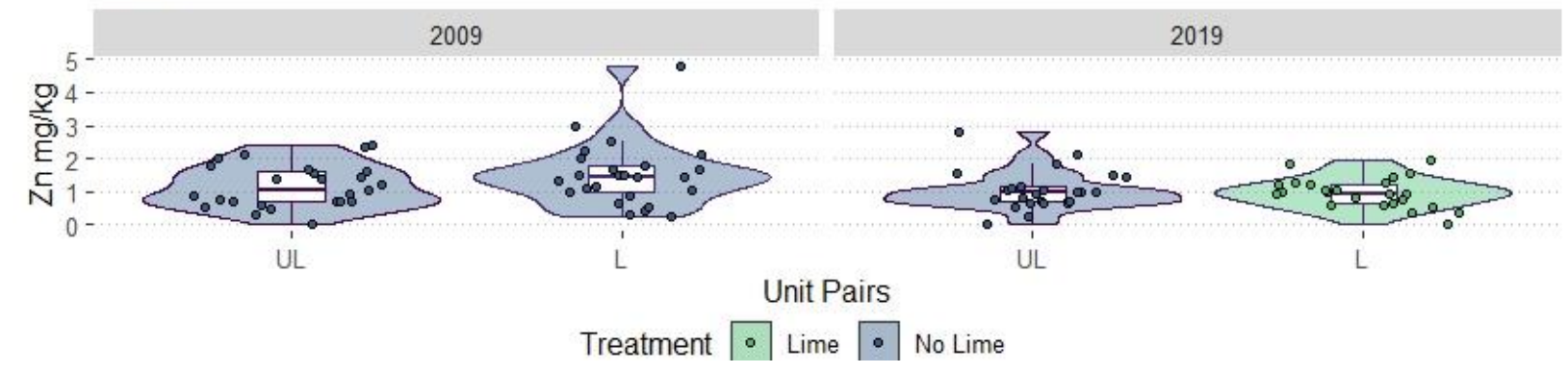

\section{Discussion}

One of the purposes of this study was to monitor the soil response of liming application to determine whether liming raised $\mathrm{pH}$ and $\mathrm{Ca}$ levels, and decreased soil acidity and Al levels in the $\mathrm{O}, \mathrm{A}$, and upper $\mathrm{B}$ horizons of the forest soils in the MNF.

In the MNF, soils with the liming treatment showed significantly higher $\mathrm{pH}$ levels in the O horizon (4.6 vs 5.9). In the A and B horizons, there was no significant difference between Limed and Unlimed sites in 2019. Ca concentrations were increased by more than three times with liming in both the $\mathrm{O}$ and $\mathrm{A}$ horizons, while $\mathrm{Al}$ concentrations were decreased by half or more in both horizons.

Long et al. (2015) found that liming with pulverized dolomitic limestone at $22 \mathrm{Mg} / \mathrm{ha}$ increased $\mathrm{pH}, \mathrm{Ca}$, and $\mathrm{Mg}$ levels, and that these higher values persisted 21 years after 
application at depths of up to $45 \mathrm{~cm}$. At the same time, decreases in $\mathrm{Al}$ and $\mathrm{Mn}$ concentrations occurred during these years. Soil sampling for the Long et al. (2015) study took place during years $1,4,8,11,16$, and 21 post liming so it was possible to compare the results of both studies. The Limed sites from our WV study had very similar results in the first year after liming when compared with the limed sites in Long et al. (2015). In the $\mathrm{O}$ and $\mathrm{A}$ horizons, Long et al. (2015) found increased levels of $\mathrm{pH}$ and exchangeable $\mathrm{Ca}$, as well as decreased levels of Al (Tables 18-20).

Table 18. Average $\mathrm{pH}$ values for first-year results after liming for the Fowler et al. and Long et al. studies.

\begin{tabular}{|c|c|c|c|c|c|c|}
\hline pH & \multicolumn{3}{|c|}{$1^{\text {st }}$ Year Post Liming } & \multicolumn{2}{c|}{$4^{\text {th }}$ Year Post Liming } \\
\hline Horizon & \multicolumn{2}{|c|}{ Fowler et al. } & \multicolumn{2}{|c|}{ Long et al. } & \multicolumn{2}{|c|}{ Long et al. } \\
\hline & Unlimed & Limed & Unlimed & Limed & Unlimed & Limed \\
\hline O & 4.6 & 5.9 & 3.7 & 5.5 & 3.7 & 5.7 \\
\hline A & 4.3 & 4.6 & 3.9 & 4.2 & 3.9 & 4.4 \\
\hline
\end{tabular}

Table 19. Average Ca concentrations $(\mathrm{cmol}+/ \mathrm{kg})$ for first-year results after liming for the Fowler et al. and Long et al. studies.

\begin{tabular}{|c|c|c|c|c|c|c|}
\hline Ca & \multicolumn{4}{|c|}{$1^{\text {st }}$ Year Post Liming } & \multicolumn{2}{c|}{$4^{\text {th }}$ Year Post Liming } \\
\hline Horizon & \multicolumn{2}{|c|}{ Fowler et al. } & \multicolumn{2}{|c|}{ Long et al. } & \multicolumn{2}{c|}{ Long et al. } \\
\hline & Unlimed & Limed & Unlimed & Limed & Unlimed & Limed \\
\hline O & 7.9 & 27.2 & 1.8 & 9.5 & 1.7 & 9.0 \\
\hline A & 0.5 & 3.2 & 0.2 & 0.4 & 0.3 & 0.8 \\
\hline
\end{tabular}

Table 20. Average Al concentrations $(\mathrm{mg} / \mathrm{kg}$ ) for first-year results after liming for the Fowler et al. and Long et al. studies.

\begin{tabular}{|c|c|c|c|c|c|c|}
\hline $\mathrm{Al}$ & \multicolumn{4}{|c|}{$1^{\text {st }}$ Year Post Liming } & \multirow{2}{*}{\multicolumn{2}{|c|}{$\begin{array}{c}4^{\text {th }} \text { Year Post Liming } \\
\text { Long et al. }\end{array}$}} \\
\hline Horizon & \multicolumn{2}{|c|}{ Fowler et al. } & \multicolumn{2}{|c|}{ Long et al. } & & \\
\hline & Unlimed & Limed & Unlimed & Limed & Unlimed & Limed \\
\hline
\end{tabular}




\begin{tabular}{|l|l|l|l|l|l|l|}
\hline $\mathrm{O}$ & 261.0 & 58.0 & 33.3 & 15.3 & 31.5 & 13.5 \\
\hline $\mathrm{A}$ & 627.0 & 325.0 & 42.3 & 39.6 & 45.0 & 36.9 \\
\hline
\end{tabular}

The $\mathrm{pH}$ of $\mathrm{O}$ horizons was lower in unlimed soils in the Long et al. (2015) study with a pH of 3.7 compared to the $\mathrm{pH}$ in our Unlimed sites at 4.6 (Table 18). But liming increased the $\mathrm{pH}$ of O horizons to between 5.5 to 5.9 in both studies. In A horizons after the first year in both studies, soil pH with liming was more modest: $\mathrm{pH}$ increasing from 3.9-4.3 to 4.2-4.6.

Calcium concentrations increased dramatically in O horizons in both studies with a three-fold increase in our study $(7.9$ to $27.2 \mathrm{cmol}+/ \mathrm{kg}$ ) and a five-fold increase in Long et al. (1.8 to $9.5 \mathrm{cmol}+/ \mathrm{kg}$ ) (Table 19). After four years, the Ca levels remained unchanged from the firstyear results in Long et al.

Al concentrations decreased by almost $80 \%$ (261 to $58 \mathrm{mg} / \mathrm{kg}$ ) in our study and were decreased by $50 \%$ in Long et al. (Table 20 ). Al concentration decreases in A horizons were not as dramatic. Results of sampling after four years showed similar results to first-year results.

The liming material in the Long et al. (2015) study was pulverized and was expected to dissolve and move into the soil more rapidly than the sand-sized lime used in our study. However, we found similar values of $\mathrm{pH}$ and $\mathrm{Ca}$ in the $\mathrm{O}$ horizons as they found after one year post liming. The solutions used for extracting elements were not the same and could account for high levels of Ca and Al extracted from the WV soils. The Long et al. (2015) study used $\mathrm{NH}_{4} \mathrm{OAc}$ for extraction while our study used $\mathrm{NH}_{4} \mathrm{Cl}$ for extraction. The $\mathrm{pH}$ of $\mathrm{NH}_{4} \mathrm{Cl}$ solutions (used for WV soils) is slightly acidic (pH 5.0 to 6.0), while $\mathrm{NH}_{4} \mathrm{OAc}$ solutions (used for PA soils) have a $\mathrm{pH}$ of 7.0. Therefore, it would be expected that more Ca and Al would be extracted with $\mathrm{NH}_{4} \mathrm{Cl}$ than $\mathrm{NH}_{4} \mathrm{OAc}$. Shuman and Duncan (1990) recommended that $\mathrm{NH}_{4} \mathrm{Cl}$ be used for extracting ions from recently limed samples, while $\mathrm{NH}_{4} \mathrm{OAc}$ be used for extracting samples not recently limed, nor containing residual lime (see also Ciesielski and Sterckeman, 1997). Tables 19-20 do indeed show more $\mathrm{Ca}$ and $\mathrm{Al}$ were extracted using $\mathrm{NH}_{4} \mathrm{Cl}$ in our study compared to 
$\mathrm{NH}_{4} \mathrm{OAc}$ in the Long et al. (2015) study, but the relative changes in concentrations seem to be consistent between studies.

The sand-sized liming material used in the WV study will continue to dissolve but at very slow rates. It is expected that lime material that passed through a 60 -mesh sieve $(50 \%$ or about $4 \mathrm{Mg} / \mathrm{ha}$ ) has likely reacted and dissolved in these acid forest soils and the remaining $50 \%$ of the lime material will be much slower and take many more years to react. Liu et al. (2005) showed that the dissolution rate for dolomite is much lower than that of calcite and that limestone dissolution rate is around 4 to 60 times faster than dolomite (see Jones Jr. (2016). Therefore, the dolomitic limestone used in the Long et al. (2015) study should be slower reacting even with smaller particle size. Nevertheless, the limestone used in our study, because of its large particle size, will take many years to dissolve.

The results in the MNF study look promising and we can only surmise that the Limed sites in the MNF may experience this same long-lasting effect 21 years after liming that was found by Long et al. (2015). The liming application rate in Long et al. (2015) was higher at 22.4 $\mathrm{Mg} / \mathrm{ha}$ while the liming rate for our MNF study was about half that (6.7 to $11.2 \mathrm{Mg} / \mathrm{ha}$ ). Their lime material was finely ground dolomitic limestone, and the CCE of the lime used in Long et al. (2015) was listed at 105.6\%. Our material was sand-sized calcite (a small amount of Mg at 3.3\%) with $90 \%$ CCE.

Liming also had an effect on OM and TC as both of these decreased in the $\mathrm{O}$ and $\mathrm{A}$ horizons. This could be related to the increased $\mathrm{pH}$ levels which may have increased microbial activity as reported from Andersson et al. (1999), Driscoll et al. (1996), and Moore et al. (2014). The Limed sites also had decreased $\mathrm{K}$ concentrations in the $\mathrm{O}$ horizons. This same result can be said for Fe as well. The decrease of $\mathrm{P}$ in the $\mathrm{O}$ horizon was also significant on Limed sites, which also could be influenced by increased microbial activities and P uptake as found in Haynes (1982).

For the last objective, the study design also allowed for a comparison of unlimed soils between 2009 and 2019. We found that $\mathrm{pH}$ of $\mathrm{O}$ and $\mathrm{A}$ horizons in Unlimed soils in 2009 were 4.3 and 3.9 compared to 4.6 and 4.3 for these same Unlimed soils in 2019. Calcium 
concentrations declined in soils between 2009 and 2019 from 8.3 to $7.9 \mathrm{cmol}+/ \mathrm{kg}$ in O horizons and 0.9 an $0.5 \mathrm{cmol}+/ \mathrm{kg}$ in A horizons. Acidity values slightly increased between 2009 and 2019; 7 vs $11 \mathrm{cmol}+/ \mathrm{kg}$ in O horizons and 8 vs $11 \mathrm{cmol}+/ \mathrm{kg}$ in 2019. Aluminum concentrations were similar in O (275 vs 261) and A (585 vs 627) horizons between 2009 and 2019, respectively.

In our WV study, pH levels in Unlimed sites rose slightly (4.3 to 4.6) between 2009 and 2019 while soils in the Drohan and Sharpe (1997) and Bailey et al. (2005) studies decreased. Our Unlimed sites in 2009 and 2019 showed decreases in Ca in the $\mathrm{O}$ and $\mathrm{A}$ horizons which were similar to their results. But the sampling span of 10 years in our study was much shorter than their 20- and 30-yr studies.

Farr et al. (2009) measured soil properties of A and B horizons in the MNF and described the low $\mathrm{Ca} / \mathrm{Al}$ ratios in these soils. Unfortunately, their sampling did not include $\mathrm{O}$ horizons to which we could compare our results. Their study, which sampled soils in 2004 in the nearby Cherry River watershed of WV, had average $\mathrm{pH}$ values in the A horizon of 3.7 to 4.0 compared to our study with average $\mathrm{pH}$ of 3.7 to 3.9 in 2009 and 4.3 in 2019. Their Ca concentrations in A horizons of $0.7 \mathrm{cmol}+/ \mathrm{kg}$ compared to our values of $0.9 \mathrm{cmol}+/ \mathrm{kg}$ in 2009 and $0.5 \mathrm{cmol}+/ \mathrm{kg}$ in 2019. Their acidity values in A horizons were $7.8 \mathrm{cmol}+/ \mathrm{kg}$, while ours were $7 \mathrm{cmol}+/ \mathrm{kg}$ in 2009 and $11 \mathrm{cmol}+/ \mathrm{kg}$ in 2019. This shows that the soils in the MNF were similar in pH between 2004 and 2019 and remained similar in Ca and acidity, confirming the idea that these soils have not improved even when acid deposition rates were lower. Aluminum concentrations reaffirmed these results with values of $6.6 \mathrm{cmol}+/ \mathrm{kg}$ in 2004 compared to $6.8 \mathrm{cmol}+/ \mathrm{kg}$ in 2009 and 7 $\mathrm{cmol}+/ \mathrm{kg}$ in 2019 (converted to units that corresponded with their study).

Hayes (1982) documented that as soil pH increased from liming, P adsorption should increase due to occlusion of phosphate by precipitation of Al and Fe hydroxide, and therefore the solubility of P should decrease. Pabian et al. (2012b) found that liming had little effect on exchangeable $\mathrm{P}$ but did note that exchangeable $\mathrm{P}$ decreased as $\mathrm{pH}$ levels increased from 4.0 to 4.7 over the five years of their study. Though this is only the first year of our WV study, liming showed reduced levels of $\mathrm{P}$ in both the $\mathrm{O}$ and $\mathrm{A}$ horizons and it is probable that a similar result will persist for $\mathrm{P}$ levels with higher $\mathrm{pH}$. 
Changes in tree species composition due to acid deposition has been a less important factor since 2000. Many other factors are involved in the changing conditions of these forests and their influence on tree growth, competition, and tree species losses or increases. Climate change, diseases, soil factors, annual climate with droughts, tree harvesting practices and prescribed fire (or lack of) also influence tree and herbaceous species composition in forests. Iverson and Hutchinson (2002) noted that surface fires were an important disturbance in forests from early Euro-American settlement to the 1940's, but since the 1940's fire suppression was largely implemented and is shifting forest dominance to maples and other mesic species.

In summary, for the Unlimed and To Be Limed sites in 2009 and the Unlimed sites in 2019, few significant differences were found among the averages for these sites including these parameters: \%TC, \%TN, K, Ca, Mg, Na, Al. For other elements like Fe, Mn, Zn (including pH, acidity, ECEC, \%OM, P), there were significant differences between the average values at sites in 2009 and Unlimed sites in 2019. For the Limed sites in 2019, significant differences were found in the $\mathrm{O}$ horizon averages for $\mathrm{Na}, \mathrm{Fe}, \mathrm{Mn}$, and $\mathrm{Zn}$; \% TN also shared this significance but also had significant differences in the $\mathrm{A}$ horizon as well unlike $\mathrm{Na}, \mathrm{Fe}, \mathrm{Mn}$, and $\mathrm{Zn}$. We look forward to sampling these soils at three- and five-years post mining to evaluate whether the differences (or nondifferences) will remain and what other trends may be discovered. We feel that the three- and five-year studies will provide a better representation of the liming effects on these soils.

\section{Conclusions}

The objectives of this study were to determine whether the application of lime to these soils; 1) raised $\mathrm{pH}$ and $\mathrm{Ca}$ levels in the $\mathrm{O}, \mathrm{A}$ and upper $\mathrm{B}$ horizons; 2) decreased soil acidity and Al concentrations in these horizons; 3 ) changed other elemental concentrations in soils; and 4) to determine the changes in these soils over the 10 year period from 2009 to 2019.

For objective one, liming clearly increased $\mathrm{pH}$ and increased $\mathrm{Ca}$ concentrations in $\mathrm{O}$ horizons by three times. Liming also increased the $\mathrm{pH}$ and $\mathrm{Ca}$ in $\mathrm{A}$ horizons but less so. For 
objective 2, we found that liming significantly decreased acidity concentrations from 7 to 3 $\mathrm{cmol}^{+} / \mathrm{kg}$ and decreased Al concentrations from an average of 272 to $58 \mathrm{mg} / \mathrm{kg}$. In A horizons, the decreases were less drastic. For objective 3, we found that liming increased ECEC in $\mathrm{O}$ horizons and decreased \% OM, as well as $\mathrm{Fe}, \mathrm{Mn}$, and $\mathrm{Zn}$ concentrations.

We acknowledge that the sampling procedure for the Limed sites in 2019 collected particles of unreacted lime in the samples and the increased $\mathrm{pH}$ and $\mathrm{Ca}$ concentrations which were found in these soils in 2019 are an artifact of those particles being found in the samples. We know that these improved conditions in Limed soils are artificial and not a true representation of actual changes due to liming. With time, it is expected that the lime particles will continue to be broken down and weathered (albeit slowly due to the remaining larger particle sizes), and the dissolution products of the lime will be carried into the soil. The acid soils will buffer the introduction of lime dissolution products and undoubtedly lower the perceived liming effect that we observed in our 2019 sampling. We expect that subsequent sampling of these soils will probably show lower $\mathrm{pH}$ and lower $\mathrm{Ca}$ concentrations in $\mathrm{O}$ horizons than what was measured in 2019. Future samplings in years 3 and 5 will give a much better representation of the effects of the lime application to these acid MNF soils.

The selection of sites and the sampling procedures put in place will permit the researchers to determine the effectiveness of lime application and its effects in subsequent years. We will assess whether these increases in $\mathrm{pH}$ and $\mathrm{Ca}$ concentrations, and reductions in acidity and Al concentrations will persist up to five years after the lime application in O horizons and whether lime effects will be reflected in A horizons.

For objective 4, the sampling and statistical approach in this study allowed comparisons between soils sampled in the MNF in 2009 and 2019. The Unlimed sites in 2009 and 2019 were very similar in $\mathrm{pH}$, acidity, and $\mathrm{Al}$ concentrations, showing little change during the 10 years between sampling. An earlier 2004 soil sampling study in an adjacent watershed in the MNF also showed very similar values of these parameters as was found in 2009 and 2019. Future samplings in 2021 and 2023 will allow further evaluation of changes in these soils due to time and reduced acid deposition. 


\section{References}

Adams, F. (1984). Crop response to lime in the southern United States. Soil Acidity and Liming. Agronomy Monograph, ASA, Madison, WI. https://doi.org/10.2134/agronmonogr12.2ed.c5

Adams, M.B., Burger, J.A., Jenkins, A.B., \& Zelazny, L. (2000). Impact of harvesting and atmospheric pollution on nutrient depletion of eastern US hardwood forests. Forest Ecology and Management 138:301-319. https://doi.org/10.1016/S03781127(00)00421-7

Aguilar, R. (1981). Soil-Landscape Relationships of the Tionesta Research Natural Area, Pennsylvania, M.S. Thesis, Cornell University.

American Sportfishing Association. (2019). Economic Contributions of Recreational Fishing West Virginia-. https://asafishing.org/wp-content/uploads/2021/01/West-Virginia2021.pdf

Andersson, S., Nilsson, I., \& Valeur, I. (1999). Influence of dolomitic lime on DOC and DON leaching in a forest soil. Biogeochemistry 47:295-315.

https://doi.org/10.1023/A:1006155925844

Arthur, M.A., Blankenship, B.A., Schörgendorfer, A., \& Alexander, H.D. (2017). Alterations to the fuel bed after single and repeated prescribed fires in an Appalachian hardwood forest. Forest Ecology and Management 403:126-136. https://doi/org/10.1016/j.foreco.2017.08.011

Arthur, M.A., Blankenship, B.A., Schörgendorfer, A., Loftis, D.L., \& Alexander, H.D. (2015). Changes in stand structure and tree vigor with repeated prescribed fire in an Appalachian hardwood forest. Forest Ecology and Management 340:46-61. https://doi.org/10.1016/j.foreco.2014.12.025

Bailey, S. W., Buso, D. C., \& Likens, G. E. (2003). Implications of sodium mass balance for interpreting the calcium cycle of a forested ecosystem. Ecology 84:471-484.

Bailey, S. W., Horsley, S. B., Long, R. P., \& Hallett, R.A. (2004). Influence of edaphic factors on sugar maple nutrition and health on the Allegheny Plateau. Soil Science Society of America Journal 68:243-252. https://doi.org/10.2136/sssaj2004.2430

Bailey, S. W., Horsley, S. B., \& Long, R. P. (2005). Thirty years of change in forest soils of the Allegheny Plateau, Pennsylvania. Soil Science Society of America Journal 69:681-690. https://doi.org/10.2136/sssaj2004.0057 
Battles, J. J., Fahey, T. J., Driscoll, C. T., Blum, J. D., \& Johnson, C. E. (2014). Restoring soil calcium reverses forest decline. Environmental Science \& Technology Letters 1:15-19. https://doi.org/10.1021/ez400033d

Berger, T., Turtscher, S., Berger, P., \& Lindebner, L. (2016). A slight recovery of soils from acid rain over the last three decades is not reflected in the macro nutrition of beech (Fagus sylvatica) at 97 forest stands of the Vienna Woods. Environ Pollut 216:624-635. https://doi.org/10.1016/j.envpol.2016.06.024

Bigelow S.W., \& Canham, C.D. (2002). Community organization of tree species along soil gradients in a north-eastern USA forest. Journal of Ecology 90:188-200

Blair, J.M., \& Crossley Jr, D.A. (1988). Litter decomposition, nitrogen dynamics, and litter microarthropods in a southern Appalachian hardwood forest 8 years following clearcutting. Journal of applied Ecology 25:683-698. https://doi.org/10.2307/2403854

Blake, L., Goulding, K., Mott, C., \& Johnston, A. (1999). Changes in soil chemistry accompanying acidification over more than 100 years under woodland and grass at Rothamsted Experimental Station, UK. European Journal of Soil Science 50:401-412. https://doi.org/10.1046/i.1365-2389.1999.00253.x.

Burke, M. K., \& Raynal, D. J. (1998). Liming influences growth and nutrient balances in sugar maple ( acer saccharum) seedlings on an acidic forest soil. Environmental and Experimental Botany 39:105-116. https://doi.org/10.1016/S0098-8472(97)00029-4

Burns, D. A., Aherne, J., Gay, D., \& Helmann, C. (2016). Acid rain and its environmental effects: recent scientific advances. Atmospheric Environment 146:1-4. https://doi.org/10.1016/j.atmosenv.2016.10.019

Burtraw, D., Krupnick, A., Mansur, E., Austine, D., \& Farrell, D. (2007). Costs and benefits of reducing air pollutants related to acid rain. Contemporary Economic Policy 16:379. https://doi.org/10.1111/i.1465-7287.1998.tb00527.x

Cavender, J. H., Hoffman, A. J., \& Kircher, D. S. (1973). Nationwide Air Pollutant Emission Trends, 1940-1970: By James H. Cavender, David S. Kircher and Alan Hoffman. US Environmental Protection Agency, Office of Air Quality Planning and Standards; [available from the Air Pollution Technical Information Center, Environmental Protection Agency or from the Superintendent of Documents, Washington].

Ciesielski, H., \& Sterckeman, T. (1997). A comparison between three methods for the determination of cation exchange capacity and exchangeable cations in soils. Agronomie, 17(1) 19-16 https://doi.org/10.1051/argo:19970102

Civerolo, K. L., Brankov, E., Rao, S. T., \& Zurbenko, I. G. (2001). Assessing the impact of the acid deposition control program. Atmospheric Environment 35:4135-4148. 
Connolly, S. J., Cain, T. C., Vestal, J. S., \& Edwards, P. J. (2007). The potential effects of acid deposition: what's a national forest to do?. In Advancing the Fundamental Sciences: Proceedings of the Forest Service National Earth Sciences Conference, San Diego, CA, 18-22 (Vol. 2, p. 428). US Forest Service, Pacific Northwest Research Station.

Cotton, C. (2006). Developing a method of site quality evaluation for Quercus alba and Liriodendron tulipifera in the eastern Kentucky coal field. M.S. thesis. Univ. of Kentucky, Lexington.

Craul, P. (1964). An Analysis of Site Index Variation and Certain Soil Characteristics of Dekalb Very Stony Sandy Loam, Ph.D. Thesis, The Pennsylvania State University, 128 pp

Cronan, C. S., \& Grigal, D. F. (1995). Use of calcium/aluminum ratios as indicators of stress in forest ecosystems. Journal of Environmental Quality 24:209-226.

DEC. (2014). Department of Environmental Conservation, New York. Available from http://www.dec.ny.gov/press/89220.html

Demchik, M., \& Sharpe, W.E. (2000). The effect of soil nutrition, soil acidity, and drought on northern red oak (Quercus rubra L.) growth and nutrition on Pennsylvania sites with high and low red oak mortality. Forest Ecology and Management 136:199-207.

Derome, J., Kukkola, M., Smolander, A., \& Lehto, T. (2000). Liming of forest soils. Forestry Sciences 65:328-337.

Driscoll, C. T., Cirmo, C. P., Fahey, T. J., Blette, V. L., Bukaveckas, P. A., Burns, D. A., \& Porcella, D. B. (1996). The experimental watershed liming study: comparison of lake and watershed neutralization strategies. Biogeochemistry 32:143-174.

Driscoll, C.T., Lawrence, G.B., Bulger, A.J., Butler, T.J., Cronan, C.S., Eagar, C., Lambert, K.F., Likens, G.E., Stoddard, J.L., \& Weathers, K.C. (2001). Acidic deposition in the Northeastern United States: sources and inputs, ecosystem effects, and management strategies. BioScience 51:180-198. https://doi.org/10.1641/00063568(2001)051[0180:ADITNU]2.0.CO;2

Driscoll, C., Driscoll, K., Mitchell, M., \& Raynal, D. (2003). Effects of acidic deposition on forest and aquatic ecosystems in New York State. Environmental Pollution 123:327-336. https://doi.org/10.1016/S0269-7491(03)00019-8

Drohan, J. R., \& Sharpe, W. E. (1997). Long-term changes in forest soil acidity in Pennsylvania, U.S.A. Water, Air, and Soil Pollution : An International Journal of Environmental Pollution 95:299-311. https://doi.org/10.1007/BF02406171

Dubitzky, W., Wolkenhauer, O., Cho, KH., \& Yokota, H. (2013). Tukey-Kramer Method. (eds) Encyclopedia of Systems Biology. Springer, New York, NY. https://doi.org/10.1007/978-1-4419-9863-7 101575 
Dukes, C.J., Coates, T.A., Hagan, D.L., Aust, W.M., Waldrop, T.A., Simon, D.M. (2020) Long term effects of repeated prescribed fire and fire surrogate treatments on forest soil chemistry in the southern Appalachian mountains (USA). Fire. 3,2:20

https://doi.org/10.3390/fire3020020

Elias, P. E., Burger, J. A., \& Adams, M. B. (2009). Acid deposition effects on forest composition and growth on the Monongahela National Forest, West Virginia. Forest Ecology and Management 258:2175-2182. https://doi.org/10.1016/i.foreco.2009.05.004

Engle, C. (1964). Cation Exchange Capacity Determinations on Pennsylvania Soils: Comparison of Methods of Determination and Components of Charge, Ph.D. Thesis, The Pennsylvania State University, 126 pp.

Farr, C., Skousen, J., Sencindiver, J., Edwards, P., \& Connolly, S. (2009). Acid soil indicators in forest soils of the Cherry River Watershed, West Virginia. Environmental Monitoring and Assessment 158:343-353. https://doi.org/10.1007/s10661-008-0588-8

Federer, C. A., Hornbeck, J. W., Tritton, L. M., Martin, C. W., Pierce, R. S., \& Smith, C. T. (1989). Long-term depletion of calcium and other nutrients in eastern US forests. Environmental Management 13:593-601. https://doi.org/10.1007/BF01874965

Formanek, P., \& Vranova, V. (2003). A contribution to the effect of liming of forest soils: review of literature. J. of Forest Science 48:182-190.

Gallagher, J., \& Baker, J. (1990). Current status of fish communities in Adirondack Lakes. Pages 3-11 to 3-48 in Adirondack Lakes Survey: An Interpretive Analysis of Fish Communities and Water Chemistry, 1984-1987. Ray Brook (NY): Adirondacks Lakes Survey Corporation.

Garten Jr, C.T., Post III, W.M., Hanson, P.J., \& Cooper, L.W. (1999). Forest soil carbon inventories and dynamics along an elevation gradient in the southern Appalachian Mountains. Biogeochemistry 45:115-145. https://doi.org/10.1007/BF01106778

Gazal, K., Gabbert, C., McNeel, J., \& McGill, D. (2017). An Assessment of the Economic Importance of the Forest Products Industry to WV's Economy. http://economic-impactof-ag.com/WV/WV2017-ReportAn Assessment of the Economic Importance of the Forest Products Industry to WV Economy 2015-1zqqf27.pdf

Gilliam, F.S., Turrill, N.L., \& Adams, M.B. (1995). Herbaceous-layer and overstory species in clear-cut and mature central Appalachian hardwood forests. Ecological Applications 5:947-955. https://doi.org/10.2307/2269345

Gilliam, F.S. (2002). Effects of harvesting on herbaceous layer diversity of a central Appalachian hardwood forest in West Virginia, USA. Forest Ecology and Management 155:33-43. https://doi.org/10.1016/S0378-1127(01)00545-X 
Godbold, D.L., Fritz, E., \& Huttermann, A. (1988). Aluminum toxicity and forest decline. Ecology 85:3888-3892.

Greenstone, M. (2004). Did the Clean Air Act cause the remarkable decline in sulfur dioxide concentrations?. Journal of environmental economics and management 47:585-611.

Greenfelt, P., Engleryd, A., Forsius, M., Hov, Q, Rodhe., \& Cowling, E. (2020). Acid rain and air pollution: 50 years of progress in environmental science and policy. Ambio 49:849-864. https://doi.org/10.1007/s13280-019-01244-4

Harald, S., Liisa, M., Mattias, A., Filip, M., Veronika Kronnäs., \& Munthe, J. (2005). Modeling recovery of Swedish ecosystems from acidification. Ambio 34:25-31.

Hartman, M., Howes, C.G., Vanlnsberghe, D., Yu, H., Bachar, D., Christen, R., Nilsson, R. H., Hallam, S. J., \& Mohn, W. W. (2012). Significant and persistent impact of timber harvesting on soil microbial communities in northern coniferous forests. The ISME Journal 6:2199-2218. https://doi.org/10.1038/ismej.2012.84

Haynes, R. J. (1982). Effects of liming on phosphate availability in acid soils: a critical review. Plant and Soil, 68(3), 289-308. https://doi.org/10.007BF02197935

Hindar, A., Nilsen, P., Skiple, A., \& Høgberget, R. (1995). Counteractions against acidification in forests ecosystems. effects on stream water quality after dolomite application to forest soil in Gjerstad, Norway. Water, Air, and Soil Pollution 85:1027-1032. https://doi.org/10.1007/BF00476965

Holst, A. (2020). Clean Air Act. Encyclopedia Britannica, Inc. https://www.britannica.com/topic/Clean-Air-Act-United-Sttes-1970

Hudy, M., Downey, D. M., \& Bowman, D. W. (2000). Successful restoration of an acidified native brook trout stream through mitigation with limestone sand. North American Journal of Fisheries Management 20:453-466. https://doi.org/10.1577/15488675(2000)020<0453:SROAAN>2.3.CO;2

Huettl, R. F., \& Zoettl, H. W. (1993). Liming as a mitigation tool in Germany's declining forestsreviewing results from former and recent trials. Forest Ecology and Management 61:325-338. https://doi.org/10.1016/0378-1127(93)90209-6

Jansone, L., Von Wilpert, K., \& Hartmann, P. (2020). Natural recovery and liming effects in acidified forest soils in SW-Germany. Soil Systems 4:38. https://doi.org/10.3390/soilsystems4030038

Jenkins, A.B. (2002). "Organic carbon and fertility of forest soils on the Allegheny Plateau of West Virginia". Graduate Theses, Dissertations, and Problem Reports. 1525. https://researchrepository.wvu.edu/etd/1525 
Johnson, C. E. (2002). Cation exchange properties of acid forest soils of the northeastern USA. European Journal of Soil Science 53:271-282. https://doi.org/10.1046/j.13652389.2002.00441.x

Johnson, C. E., Romanowicz, R. B., \& Siccama, T. G. (1997). Conservation of exchangeable cations after clear-cutting of a northern hardwood forest. Canadian Journal of Forest Research 27:859-868. https://doi.org/10.1139/x96-192

Johnson, A. H., \& Siccama, T. G. (1983). Acid deposition and forest decline. Environmental Science \& Technology 17:294. https://doi.org/10.1021/es00113a717

Johnson, J.E., Smith D.W., \& Burger, J.A. (1985). Effects on the forest floor of whole-tree harvesting in an Appalachian oak forest. The American Midland Naturalist 114: 51-61 https://doi.org/10.2307/24252

Jones Jr, J.D. (2016). Influence of source and particle size of agricultural limestone on efficiency at increasing soil pH. Graduate Theses and Dissertations. 15330. https://lib.dr.iastate.edu/etd/15330

Jurgensen, M.F., Harvey, A.E., Graham, R.T., Page-Dumroese, D.S, Tonn, J.R., Larsen, M.J., \& Jain, T.B. (1997). Impacts of timber harvesting on soil organic matter, nitrogen, productivity, and health on inland northwest forests. Forest Science-Washington 43:234-251. https://www.fs.fed.us/rm/pubs exp forests/coram/rmrs 1997 jurgensen m001.pdf

Kassambara, A. (2020). ggpubr: 'ggplot2' Based Publication Ready Plots. R package version 0. 4. 0. https://CRAN.R-project.org/package=ggpubr

Kaupenjohann, M. et al. (1989). Effects of Acid Rain on Soil Chemistry and Nutrient Availability in the Soil. In: Schulze ED., Lange O.L., Oren R. (eds) Forest Decline and Air Pollution. Ecological Studies (Analysis and Synthesis), vol 77. Springer, Berlin, Heidelberg. https://doi.org/10.1007/978-3-642-61332-6 14

Koglemann, W.J., Sharpe, W.E. (2006). Soil acidity and manganese in declining and nondeclining sugar maple stands in Pennsylvania . Journal of Environmental Quality vol 35 2:433-441. https://doi.org/10.2134/jeq2004.0347

Kretser, W., Gallagher, J., Nicolette, J. (1989). Adirondack lakes study, 1984-1987 : An Evaluation of Fish Communities and Water Chemistry. Ray Brook (NY): Adirondack Lakes Survey Corporation.

Krug, E., \& Frink, C. (2010). Acid rain on acid soil: a new perspective. Science 221:520-525. https://gen2.ca/DBHS/ScholarlyArticles/Katherine\%20Leiva.pdf 
Larssen, T., Schnoor, J., Seip, H., \& Dawei, Z. (2000). Evaluation of different approaches for modeling effects of acid rain on soils in China. Sci Total Env. 246:175-193. https://doi.org/10.1016/S0048-9697(99)00457-X

Lawrence, G. B., Shortle, W. C., David, M. B., Smith, K. T., Warby, R. A. F., \& Lapenis, A. G. (2012). Early indications of soil recovery from acidic deposition in US red spruce forests. Soil Science Society of America Journal 76:1407-1417. https://doi.org/10.2136/sssaj2011.0415

Lawrence, G., Hazlett, P., Fernandez, J., Bailey, S., Shortle, W., Smith, K., \& Antidormi, M. (2015). Declining acidic deposition begins reversal of forest-soil acidification in the northeastern U.S. and Eastern Canada. Environ Sci Technol 49:13103-13111. https://doi.org/10.1021/acs.est.5b02904

Likens, G. E., \& Butler T. J. (2019). Acid Rain. Encyclopedia Britannica Inc. https://www.britannica.com/science/acid-rain

Likens, G. E., Driscoll, C. T., \& Buso, D. C. (1996). Long-term effects of acid rain: response and recovery of a forest ecosystem. Science 272:244-246.

Long, R. P., Horsley, S. B., Bailey, S. W., Hall, T. J., Swistock, B. R., \& DeWalle, D. R. (2015). Longterm effects of forest liming on soil, soil leachate, and foliage chemistry in northern Pennsylvania. Soil Science Society of America Journal 79:1223-1236. https://doi.org/10.2136/sssaj2014.11.0465

Lyon, J., \& Sharpe, W. E. (1999). An assessment of the Ca:Al ratios of selected Pennsylvania forest soils. Water, Air, and Soil Pollution 109:53-65. https://doi.org/10.1023/A:1005042426912.

Mant, R.C., D.L. Jones, B. Reynolds, S.J. Ormerod., \& A.S. Pullin. (2013). A systematic review of the effectiveness of liming to mitigate impacts of river acidification on fish and macroinvertebrates. Environmental Pollution 179:285-293. http://www.sciencedirect.com/science/article/pii/S0269749113002200

Markewitz, D., Richter, D.D., Allen, H. L., \& Urrego, J. B. (1998). Three decades of observed soil acidification in the Calhoun Experimental Forest: Has acid rain made a difference? Soil Science Society of America Journal 62:1428-1439.

McCoy, J. (2018). Charleston Gazette-Mail: "Bucks from bucks: WV hunters create half-billion dollar impact on state's economy." https://www.wvgazettemail.com/outdoors/john mccoy/bucks-from-bucks-wv-hunterscreate-half-billion-dollar-impact-on-states-economy-daily-mail/article 950c91c8-dc81$\underline{\text { 52fa-96ae-dd92c941cc8d.html }}$ 
McShea, W. J., Healy, W. M., Devers, P., Fearer, T., Koch, F. H., Stauffer, D., \& Waldon, J. (2007). Forestry Matters: Decline of Oaks Will Impact Wildlife in Hardwood Forests. The Journal of Wildlife Management. https://doi.org/10.2193/2006-169

Menz, F., \& Seip, H. (2004). Acid rain in Europe and the United States: an update. Environ Sci \& Policy 7:253-265. https://doi.org/10.1016/j.envsci.2004.05.005

Mizel, N. L., Sharpe, W. E., \& Swistock, B. R. (2015). Efficacy of Pelletized Lime versus Limestone Sand for Forest Regeneration Enhancement in Pennsylvania, USA. Open Journal of Forestry 5:221. http://file.scirp.org/Html/9-1620248 53543.htm

Moore, J. D., Camire, C., \& Quimet, R. (2000). Effects of liming on the nutrition, vigor, and growth of sugar maple at the Lake Clair Watershed, Quebec Canada. Canadian Journal of Forest Research 30:725-732.https://doi.org/10.1139/x00-009

Moore, J. D., Duchesne, L., \& Ouimet, R. (2008). Soil properties and maple-beech regeneration a decade after liming in a northern hardwood stand. Forest Ecology and Management 255:3460-3468. http://www.sciencedirect.com/science/article/pii/S037811270800203X

Moore, J. D., \& Quimet, R. (2006). Ten-year effect of dolomitic lime on the nutrition, crown vigor, and growth of sugar maple. Canadian Journal of Forest Research 36:1834-1841.

Moore, J. D., Ouimet, R., Long, R. P., \& Bukaveckas, P. A. (2014). Ecological benefits and risks arising from liming sugar maple dominated forests in northeastern North America. Environmental Reviews 23:66-77. http://www.fs.fed.us/nrs/pubs/jrnl/2015/nrs_2015 moore_001.pdf

National Atmospheric Deposition Program (NRSP-3). (2021a). NADP Program Office, Wisconsin State Laboratory of Hygiene, 465 Henry Mall, Madison, WI 53706. http://nadp.slh.wisc.edu/data/sites/siteDetails.aspx?net=NTN\&id=WV04

National Atmospheric Deposition Program (NRSP-3). (2021b). NADP Program Office, Wisconsin State Laboratory of Hygiene, 465 Henry Mall, Madison, WI 53706. http://nadp.slh.wisc.edu/data/animaps.aspx

National Atmospheric Deposition Program. (2020). National Atmospheric Deposition Program National Trends Network. https://www.usgs.gov/centers/oki-water/science/nationalatmospheric-deposition-program-national-trends-network?qtscience center objects=0\#qt-science center objects

National Geographic. (2018). Acid rain facts and information. Acid Rain. National Geographic https://www.nationalgeographic.com/environment/global-warming/acid-rain/\#close 
Newton, R., Burns, D., Blette, V., \& Driscoll, C. (1996). Effect of whole catchment liming on the episodic acidification of two Adirondack streams. Biogeochemistry 32:299-322. https://www.jstor.org/stable/1469266

Nierzwicki-Bauer, S. A., Boylen, C. W., Eichler, L. W., Harrison, J. P., Sutherland, J. W., Shaw, W., \& Bukaveckas, P. (2010). Acidification in the Adirondacks: defining the biota in trophic levels of 30 chemically diverse acid-impacted lakes. Environmental Science and Technology 44:5721-5721.

Pabian, S., Emer, N., Tzilkowski, W., \& Brttingham, M. (2012a). Effects of liming on forage availability and nutrient content in a forest impacted by acid rain. PloS ONE 7: https://doi.org/10.1371/journal.pone.0039755

Pabian, S. E., Rummel, S. M., Sharpe, W. E., \& Brittingham, M. C. (2012b). Terrestrial liming as a restoration technique for acidified forest ecosystems. International Journal of Forestry Research, 2012.https://www.hindawi.com/journals/ijfr/2012/976809/

Rosi-Marshall, E., Bermhardt, E., Buso, D., Driscoll, C., \& Likens, G. (2016). Acid rain mitigation experiment shifts a forested watershed from a net sink to a net source of nitrogen. PNAS 113:7580-7583. https://doi.org/10.1073/pnas.1607287113

RStudio Team. (2020). RStudio: Integrated Development for R. RStudio, PBC, Boston, MA. http://www.rstudio.com/.

Schaff, W, \& Huttl, R. (2006). Experiences with liming in European countries - results of longterm experiments. J. Forest Sci. 52. https://doi.org/10.17221/10158-JFS

Schnably, J. (2003). "Soil characterization, classification, and biomass accumulation in the Otter Creek Wilderness". Graduate Theses, Dissertations, and Problem Reports. 1800. https://researchrepository.wvu.edu/etd/1800

Schreiber, R., \& Newman, J. R. (1988). Acid precipitation effects on forest habitats: implications for wildlife. Conservation Biology 2:249-259. https://doi.org/10.1111/i.15231739.1988.tb00182.x

Schnur, G., (1937). Yield, stand and volume tables for even-aged upland oak forests. USDA Forest Service Technical Bulletin No. 560, 86 pp.

Sencindiver, J. (2010). "Soils of West Virginia." E-WV: The West Virginia Encyclopedia. 29 October 2010. Web. 21 July 2020

Shapiro, S., \& Wilk, M. (1965). An analysis of variance test for normality (complete samples). Biometrika, 52(3-4), 591-611. https://doi.org/10.1093/biomet/52.3-4.591 
Shukla, J. B., Sundar, S., Shivangi., \& Naresh, R. (2013). Modeling and analysis of the acid rain formation due to precipitation and its effect on plant species. Natural Resource Modeling 26:53-65. https://doi.org/10.1111/j.1939-7445.2012.00119.x

Shuman, L.M., \& Duncan, R.R. (1990). Soil exchangeable cations and aluminum measured by ammonium chloride, potassium chloride, and ammonium acetate. Communications in Soil Science and Plant Analysis 21 (13-16), 1217-1228. https://doi.org/10.1080/00103629009368300

Simmons, J., Currie, W., Eshleman, K., Kuers,K., Monteleone, S., Negley, T., Pohlad, B., \& Thomas, C. (2008). Forest to reclaimed land use change leads to altered ecosystem structure and function. Ecological Applications 18:104-118. https://doi.org/10.1890/071117.1

Smith, D.B., Cannon, W.F., Woodruff, L.G., Solano, Federico, Kilburn, J.E., \& Fey, D.L. (2013). Geochemical and mineralogical data for soils of the conterminous United States. U.S. Geological Survey Data Series 801, 19 p. https://pubs.usgs.gov/ds/801/pdf/ds801.pdf https://pubs.usgs.gov/ds/801/downloads/

Smith, H.C., Miller, G.W., \& Lamson, N.I. (1994). Crop-tree release thinning in 65-year-old commercial cherry-maple stands (5-year results). NE-RP-694. US Dept of Agriculture, Forest Service, Northeastern Forest Experiment Station, Randor, PA, 11 p.

Snedegar, J. (2017). W.Va timber: yes, money can grow on trees. West Virginia Public Broadcasting, https://www.wvpublic.org/news/2017-04-21/w-va-timber-yes-moneycan-grow-on-trees

Statistical Analysis System. (2011). SAS/STAT systems for windows. Version 9.4. Cary, NC: SAS ${ }^{\circledR}$ Institute. Copyright (C)2002-2012

Steputis, W. (1963). A Laboratory and Field Study of the Dekalb Soil Series in the Ridge and Valley and Appalachian Plateau Provinces in Pennsylvania, M S. Thesis, The Pennsylvania State University, $115 \mathrm{pp}$.

Stevens, Carly J.; Dise, Nancy B., \& Gowing, David J. (2009). Regional trends in soil acidification and exchangeable metal concentrations in relation to acid deposition rates. Environmental Pollution 157:313-319.

Theenhaus, A., \& Schaefer, M. (1995). The effects of clear-cutting and liming on the soil macrofauna of a beech forest. Forest Ecology and Management 77:35-51. https://doi.org/10.1016/0378-1127(95)03580-4

Thomas-Van Gundy, M., \& Strager, M. (2011). Site characteristics of American chestnut, oak, and hickory witness trees on the Monongahela National Forest, West Virginia. 
Proceedings of the $17^{\text {th }}$ Central Hardwood Forest Conference - GTR-NRS-P-78.

https://www.researchgate.net/publication/259640038 Site Characteristics of Americ an Chestnut Oak and Hickory Witness Trees on the Monongahela National Forest West Virginia

USDA Forest Service. (2011). Monongahela National Forest: Land and Resource Management Plan. https://www.fs.usda.gov/Internet/FSE DOCUMENTS/stelprdb5330420.pdf

USDA Forest Service. (2020). "About the forest." USDA FS-Monongahela National Forest. www.fs.usda.gov/main/mnf/about-forest

US Energy Information Administration. (2019). Coal: current issues and trends. USEIA, https://doi.org/10.2136/sssaj2004.0057.

USEPA. (2019). Reviewing National Ambient Air Quality Standards (NAAQS): scientific and technical information. https://www.epa.gov/naaqs

USEPA. (2020). Sulfur dioxide trends. EPA website. https://www/epa.gov/air-trends/sulfurdioxide-trends

Webb, JR., Fitzhugh, RD., \& Furman, T. (1997). The acid-base status of surface waters in Otter Creek and Dolly Sods Wildernesses. A report submitted to USDA Forest Service, Monongahela National Forest, Elkins, WV. 82 p.

Westling, O., \& Hultberg, H. (1990). Liming and fertilization of acid forest soil: short-term effects on runoof from small catchments. In: Management of Nutrition in Forests under Stress. Springer, Dordrecht. https://doi.org/10.1007/978-94-011-3252-7 33

Widmann, R., \& Griffith, D. (2000). Forest Resource Statistics for the Monongahela National Forest: 2000. USDA Forest Service Resource Bulletin NE-161. https://www.fs.fed.us/ne/newtown square/publications/resource bulletins/pdfs/2004 Lne rb161.pdf

Wickham, H. (2011). The Split-Apply-Combine Strategy for Data Analysis. Journal of Statistical Software, 40(1), 1-29. https://www.jstatsoft.org/v40/i01/.

Wickham, H. (2016). ggplot2: Elegant Graphics for Data Analysis. Springer-Verlag New York. ISBN 978-3-319-24277-4, https://ggplot2.tidyverse.org.

Wickham, H., Averick, M., Bryan, J., Chang, W., D’Agostino McGowan, L., Francois, R., Grolemund, G., Hayes, A., Henry, L., Hester, J., Kuhn, M., Pedersen, T., Miller, E., Bache, S., Muller, K., Ooms, J., Robinson, D., Seidel, D., Spinu, V., Takashi, K., Vaughan, D., Wilke, C., Woo, K., \& Yutani, H. (2019). Welcome to the tidyverse. Journal of Open Source Software, 4 (43), 1686, https://doi.org/10.21105/joss.01686 
Wickham, H., Francois, R., Henry, L., \& Muller, K. (2020). dplyr: A Grammar of Data Manipulation. R Package version 1. 0. 2. https://CRAN.R-project.org/package=dplyr

Wilke, C. (2020). cowplot: Streamlined Plot Theme and Plot Annotations for 'ggplot2'. R package version 1. 1. 0. https://CRAN.R-project.org/package=cowplot

WV DNR (2019). 2018-2019 Annual Report. https://www.wvdnr.gov/admin/PDF/DNR Admin AnnualReport 2019.pdf

WV DNR. (2020). "Hunting in West Virginia." West Virginia DNR - Hunting, www.wvdnr.gov/Hunting/Hunting.shtm.

Yang, J.E., Lee, WY., Ok, Y.S. \& Skousen, J. (2009). Soil nutrient bioavailability and nutrient content of pine trees (Pinus thunbergii) in areas impacted by acid deposition in Korea. Environ Monit Assess 157: 43-50. https://doi.org/10.1007/s10661-008-0513-1

Yeager, K., \& Baruch, B. (1987). Environmental issues affecting coal technology: a perspective on US trends. Ann. Review Energy: 12:471-502. https://www.annualreviews.org/doi/10.1146/annurev.eg.12.110187.002351

Zipper, C.E., Burger, J.A., Barton, C.D., \& Skousen, J.G. (2013). Rebuilding Soils on Mined Land for native forests in Appalachia. Soil Science Society of America Journal 77:337-349. https://doi.org/10.2136/sssaj2012.0335 


\section{Appendix 1 - Data Tables for All Parameters}

Table 21. Average soil $\mathrm{pH}$ values in $\mathrm{O}$ horizons for sites sampled in the Terrestrial Liming Project. See footnotes for explanations of statistical comparison among sites, within and across years, and with liming treatment.

\begin{tabular}{|c|c|c|c|c|c|}
\hline \multicolumn{2}{|c|}{$\mathrm{pH}$} & \multirow{2}{*}{\multicolumn{2}{|c|}{$\frac{2009}{\text { Treatments }}$}} & \multirow{2}{*}{\multicolumn{2}{|c|}{$\frac{2019}{\text { Treatments }}$}} \\
\hline \multirow[t]{2}{*}{ Horizon } & \multirow[t]{2}{*}{ Paired Sites } & & & & \\
\hline & & Unlimed & To be Limed & Unlimed & Limed \\
\hline \multirow[t]{5}{*}{0} & E509/509 & $4.2 \mathrm{~b}$ & $4.5 \mathrm{a}$ & $4.4 \mathrm{a}$ & $5.4 \mathrm{c} * \mathrm{Y}$ \\
\hline & $37 / 37-3$ & $4.9 \mathrm{a}$ & $4.3 a b^{*}$ & $4.6 \mathrm{a}$ & $6.3 b * y$ \\
\hline & $31 / 37-2$ & $3.9 \mathrm{~b}$ & $4.2 \mathrm{ab}$ & $4.5 a^{\&}$ & $4.9 \mathrm{c}$ \\
\hline & $18 / 16$ & $4.5 \mathrm{~b}$ & $4.0 a b^{*}$ & $5.3 a^{\&}$ & $5.5 b c^{Y}$ \\
\hline & $1 / 3$ & $4.2 \mathrm{~b}$ & $3.9 \mathrm{~b}$ & $4.4 \mathrm{a}$ & $7.0 \mathrm{a} * \mathrm{Y}$ \\
\hline \multicolumn{2}{|c|}{ Average Total } & $4.3 \pm 0.06$ & $4.2 \pm 0.06^{\#}$ & $4.6 \pm 0.08^{U}$ & $5.9 \pm 0.08$ \# \\
\hline
\end{tabular}

\# Indicates significant main effect of treatment (average of Unlimed vs Limed sites) within year.

U Indicates significant main effect of year (average of 2009 vs 2019 sites) within Unlimed treatment.

L Indicates significant main effect of year (average of 2009 vs 2019 sites) within To be Limed vs Limed.

* Indicates significant effect of treatment within paired sites within year.

Letter superscripts indicate differences among sites within the treatments (columns) of that year. Sites within treatment that don't share the same letter are significantly different.

\& Indicates significant effect of year (2009 vs 2019) for each site of Unlimed treatments.

${ }^{\mathrm{Y}}$ Indicates significant effect of year (2009 vs 2019) for each site of To Be Limed and Limed treatments.

Table 22. Average soil pH values in A horizons for sites sampled in the Terrestrial Liming Project. See footnotes in Table 21 for letter and symbol descriptions.

\begin{tabular}{|c|c|c|c|c|c|}
\hline \multirow{2}{*}{ pH } & \multicolumn{2}{|c|}{2009} & \multicolumn{2}{c|}{2019} \\
\hline \multirow{3}{*}{ Horizon } & Paired Sites & \multicolumn{2}{|c|}{ Treatments } & \multicolumn{2}{c|}{ Treatments } \\
\cline { 2 - 6 } & & Unlimed & To be Limed & Unlimed & Limed \\
\hline \multirow{4}{*}{$\mathrm{A}$} & $\mathrm{E} 509 / 509$ & $4.1 \mathrm{a}$ & $3.9 \mathrm{a}$ & $4.9 \mathrm{a}^{\&}$ & $4.7 \mathrm{ab}^{\mathrm{Y}}$ \\
\cline { 2 - 6 } & $37 / 37-3$ & $3.4 \mathrm{~b}$ & $3.4 \mathrm{~b}$ & $3.5 \mathrm{c}$ & $4.3 \mathrm{~b}^{* \mathrm{Y}}$ \\
\cline { 2 - 6 } & $31 / 37-2$ & $3.7 \mathrm{~b}$ & $3.5 \mathrm{~b}$ & $4.3 \mathrm{bc}^{\&}$ & $4.2 \mathrm{~b}^{\mathrm{Y}}$ \\
\cline { 2 - 6 } & $18 / 16$ & $4.2 \mathrm{a}$ & $3.5 \mathrm{~b}^{*}$ & $4.7 \mathrm{ab}^{\&}$ & $4.6 \mathrm{ab}^{\mathrm{Y}}$ \\
\cline { 2 - 6 } & $1 / 3$ & $4.2 \mathrm{a}$ & $4.0 \mathrm{a}^{*}$ & $4.3 \mathrm{bc}$ & $4.9 \mathrm{a}^{* \mathrm{Y}}$ \\
\hline \multicolumn{7}{|c|}{ Average Total } & $3.9 \pm 0.03$ & $3.7 \pm 0.03^{\#}$ & $4.3 \pm 0.06^{\mathrm{U}}$ & $4.6 \pm 0.06^{\mathrm{L}}$ \\
\hline
\end{tabular}

Table 23. Average soil $\mathrm{pH}$ values in B horizons for sites sampled in the Terrestrial Liming Project. See footnotes in Table 21 for letter and symbol descriptions.

\begin{tabular}{|c|c|c|c|c|c|}
\hline \multicolumn{2}{|c|}{$\mathrm{pH}$} & \multicolumn{2}{|c|}{2009} & \multicolumn{2}{c|}{2019} \\
\hline Horizon & Paired Sites & \multicolumn{2}{|c|}{ Treatments } & \multicolumn{2}{c|}{ Treatments } \\
\cline { 3 - 5 } & & Unlimed & To be Limed & Unlimed & Limed \\
\hline
\end{tabular}




\begin{tabular}{|c|c|c|c|c|c|}
\hline \multirow[t]{5}{*}{ B } & E509/509 & $4.6 \mathrm{ab}$ & $4.4 a b$ & $4.9 \mathrm{a}^{\&}$ & $4.9 \mathrm{a}^{\mathrm{Y}}$ \\
\hline & $37 / 37-3$ & $4.2 \mathrm{~b}$ & $4.3 \mathrm{~b}$ & $4.3 \mathrm{~b}$ & $4.3 \mathrm{~b}$ \\
\hline & $31 / 37-2$ & $4.6 a$ & $4.2 b^{*}$ & $4.8 \mathrm{a}^{\&}$ & $4.3 b^{*}$ \\
\hline & $18 / 16$ & $4.7 a$ & $4.1 b^{*}$ & $4.9 a^{\&}$ & $5.0 \mathrm{a}^{Y}$ \\
\hline & $1 / 3$ & $4.7 \mathrm{a}$ & $4.7 \mathrm{a}$ & $4.8 \mathrm{a}$ & $4.9 \mathrm{a}$ \\
\hline & e Total & $4.5 \pm 0.05$ & $4.3 \pm 0.05^{\#}$ & $4.8 \pm 0.03^{U}$ & $4.7 \pm 0.03^{L}$ \\
\hline
\end{tabular}

Table 24. Average acidity values $(\mathrm{cmol}+/ \mathrm{kg})$ in O horizons for sites sampled in the Terrestrial Liming Project. See footnotes in Table 21 for letter and symbol descriptions.

\begin{tabular}{|c|c|c|c|c|c|}
\hline \multirow{2}{*}{ Acidity } & \multicolumn{2}{c|}{2009} & \multicolumn{2}{c|}{2019} \\
\hline \multirow{3}{*}{ Horizon } & Paired Sites & \multicolumn{2}{c|}{ Treatments } & \multicolumn{2}{c|}{ Treatments } \\
\cline { 3 - 6 } & & Unlimed & To be Limed & Unlimed & Limed \\
\hline \multirow{3}{*}{0} & E509/509 & $10 \mathrm{a}$ & $10 \mathrm{a}$ & $11 \mathrm{a}$ & $4 \mathrm{ab}^{* \mathrm{Y}}$ \\
\cline { 2 - 6 } & $37 / 37-3$ & $5 \mathrm{bc}$ & $4 \mathrm{~b}$ & $10 \mathrm{ab}^{\&}$ & $0 \mathrm{~b}^{* \mathrm{Y}}$ \\
\cline { 2 - 6 } & $31 / 37-2$ & $7 \mathrm{abc}$ & $6 \mathrm{~b}$ & $1 \mathrm{a}^{\&}$ & $4 \mathrm{ab}^{*}$ \\
\cline { 2 - 6 } & $18 / 16$ & $3 \mathrm{c}$ & $6 \mathrm{~b}$ & $6 \mathrm{~b}$ & $6 \mathrm{a}$ \\
\cline { 2 - 6 } & $1 / 3$ & $9 \mathrm{ab}$ & $11 \mathrm{a}$ & $14 \mathrm{a}^{\&}$ & $0 \mathrm{~b}^{* \mathrm{Y}}$ \\
\hline
\end{tabular}

Table 25. Average acidity values ( $\mathrm{cmol}+/ \mathrm{kg}$ ) in A horizons for sites sampled in the Terrestrial Liming Project. See footnotes in Table 21 for letter and symbol descriptions.

\begin{tabular}{|c|c|c|c|c|c|}
\hline \multirow{2}{*}{ Acidity } & \multicolumn{2}{c|}{2009} & \multicolumn{2}{c|}{2019} \\
\hline \multirow{3}{*}{ Horizon } & Paired Sites & \multicolumn{2}{c|}{ Treatments } & \multicolumn{2}{c|}{ Treatments } \\
\cline { 2 - 6 } & & Unlimed & To be Limed & Unlimed & Limed \\
\hline \multirow{3}{*}{$\mathrm{A}$} & $\mathrm{E} 509 / 509$ & $7 \mathrm{~b}$ & $10 \mathrm{a}$ & $8 \mathrm{~b}$ & $7 \mathrm{a}$ \\
\cline { 2 - 6 } & $37 / 37-3$ & $10 \mathrm{ab}$ & $8 \mathrm{a}$ & $11 \mathrm{ab}$ & $5 \mathrm{a}^{*}$ \\
\cline { 2 - 6 } & $31 / 37-2$ & $6 \mathrm{~b}$ & $8 \mathrm{a}$ & $10 \mathrm{~b}^{\&}$ & $8 \mathrm{a}$ \\
\cline { 2 - 6 } & $18 / 16$ & $5 \mathrm{~b}$ & $8 \mathrm{a}$ & $10 \mathrm{~b}^{\&}$ & $6 \mathrm{a}^{*}$ \\
\cline { 2 - 6 } & $1 / 3$ & $12 \mathrm{a}$ & $12 \mathrm{a}$ & $15 \mathrm{a}^{\&}$ & $6 \mathrm{a}^{* \mathrm{Y}}$ \\
\hline \multicolumn{7}{|c|}{ Average Total } & $8 \pm 1$ & $9 \pm 1$ & $11 \pm 0.5^{\mathrm{U}}$ & $6 \pm 0.5^{\text {\# }}$ \\
\hline
\end{tabular}

Table 26. Average acidity values ( $\mathrm{cmol}+/ \mathrm{kg}$ ) in B horizons for sites sampled in the Terrestrial Liming Project. See footnotes in Table 21 for letter and symbol descriptions.

\begin{tabular}{|c|c|c|c|c|c|}
\hline \multirow{2}{*}{ Acidity } & \multicolumn{2}{c|}{2009} & \multicolumn{2}{c|}{2019} \\
\hline \multirow{3}{*}{ Horizon } & Paired Sites & \multicolumn{2}{c|}{ Treatments } & \multicolumn{2}{c|}{ Treatments } \\
\cline { 2 - 6 } & & Unlimed & To be Limed & Unlimed & Limed \\
\cline { 2 - 6 } B & E509/509 & $4 \mathrm{c}$ & $6 \mathrm{a}$ & $5 \mathrm{~b}$ & $5 \mathrm{c}^{\mathrm{Y}}$ \\
\cline { 2 - 6 } & $37 / 37-3$ & $9 \mathrm{a}$ & $7 \mathrm{a}$ & $9 \mathrm{a}$ & $9 \mathrm{ab}$ \\
\cline { 2 - 6 } & $31 / 37-2$ & $4 \mathrm{bc}$ & $7 \mathrm{a}$ & $7 \mathrm{ab}^{\&}$ & $11 \mathrm{a}^{* \mathrm{Y}}$ \\
\cline { 2 - 6 } & $18 / 16$ & $4 \mathrm{bc}$ & $6 \mathrm{a}$ & $6 \mathrm{ab}^{\&}$ & $5 \mathrm{c}$ \\
\hline
\end{tabular}




\begin{tabular}{|c|c|c|c|c|c|}
\hline & $1 / 3$ & $8 \mathrm{ab}$ & $7 \mathrm{a}$ & $9 \mathrm{ab}$ & $7 \mathrm{bc}$ \\
\hline Average Total & $6 \pm 0.4$ & $7 \pm 0.4$ & $7 \pm 0.4^{\mathrm{u}}$ & $8 \pm 0.4$ \\
\hline
\end{tabular}

Table 27. Average ECEC values ( $\mathrm{cmol}+/ \mathrm{kg}$ ) in O horizons for sites sampled in the Terrestrial Liming Project. See footnotes in Table 21 for letter and symbol descriptions.

\begin{tabular}{|c|c|c|c|c|c|}
\hline \multicolumn{2}{|c|}{ ECEC } & \multirow{2}{*}{\multicolumn{2}{|c|}{$\begin{array}{c}2009 \\
\text { Treatments }\end{array}$}} & \multirow{2}{*}{\multicolumn{2}{|c|}{$\begin{array}{c}2019 \\
\text { Treatments }\end{array}$}} \\
\hline \multirow[t]{2}{*}{ Horizon } & \multirow[t]{2}{*}{ Paired Sites } & & & & \\
\hline & & Unlimed & To be Limed & Unlimed & Limed \\
\hline \multirow[t]{5}{*}{$\mathrm{O}$} & E509/509 & $16 \mathrm{~b}$ & 18 a & $18 a$ & $21 \mathrm{c}$ \\
\hline & $37 / 37-3$ & $29 a$ & $25 \mathrm{a}$ & $24 \mathrm{a}$ & $35 \mathrm{~b} * \mathrm{Y}$ \\
\hline & $31 / 37-2$ & $17 \mathrm{~b}$ & $20 a$ & $23 a^{\&}$ & $21 \mathrm{c}$ \\
\hline & $18 / 16$ & $17 \mathrm{~b}$ & $19 a$ & $23 a^{\&}$ & $29 \mathrm{bc}^{\mathrm{Y}}$ \\
\hline & $1 / 3$ & $18 \mathrm{~b}$ & $18 \mathrm{a}$ & $24 a^{\&}$ & $55 \mathrm{a} * \mathrm{Y}$ \\
\hline \multicolumn{2}{|c|}{ Average Total } & $19 \pm 1$ & $20 \pm 1$ & $22 \pm 2^{U}$ & $33 \pm 2^{\# L}$ \\
\hline
\end{tabular}

Table 28. Average ECEC values ( $\mathrm{cmol}+/ \mathrm{kg}$ ) in A horizons for sites sampled in the Terrestrial Liming Project. See footnotes in Table 21 for letter and symbol descriptions.

\begin{tabular}{|c|c|c|c|c|c|}
\hline \multicolumn{2}{|c|}{ ECEC } & \multicolumn{2}{c|}{2009} & \multicolumn{2}{c|}{2019} \\
\hline \multirow{3}{*}{ Horizon } & Paired Sites & \multicolumn{2}{c|}{ Treatments } & \multicolumn{2}{c|}{ Treatments } \\
\cline { 3 - 6 } & & Unlimed & To be Limed & Unlimed & Limed \\
\hline \multirow{4}{*}{$\mathrm{A}$} & $\mathrm{E} 509 / 509$ & $7 \mathrm{~b}$ & $11 \mathrm{a}$ & $9 \mathrm{~b}$ & $8 \mathrm{~b}$ \\
\cline { 2 - 6 } & $37 / 37-3$ & $12 \mathrm{ab}$ & $9 \mathrm{a}$ & $12 \mathrm{ab}$ & $9 \mathrm{~b}$ \\
\cline { 2 - 6 } & $31 / 37-2$ & $7 \mathrm{~b}$ & $9 \mathrm{a}$ & $11 \mathrm{~b}^{\&}$ & $10 \mathrm{ab}$ \\
\cline { 2 - 6 } & $18 / 16$ & $8 \mathrm{ab}$ & $9 \mathrm{a}$ & $12 \mathrm{~b}^{\&}$ & $8 \mathrm{~b} *$ \\
\cline { 2 - 6 } & $1 / 3$ & $13 \mathrm{a}$ & $14 \mathrm{a}$ & $17 \mathrm{a}^{\&}$ & $15 \mathrm{a}$ \\
\hline \multicolumn{7}{|c|}{ Average Total } & $10 \pm 1$ & $10 \pm 1$ & $12 \pm 1^{\mathrm{U}}$ & $10 \pm 1^{\#}$ \\
\hline
\end{tabular}

Table 29. Average ECEC values $(\mathrm{cmol}+/ \mathrm{kg})$ in B horizons for sites sampled in the Terrestrial Liming Project. See footnotes in Table 21 for letter and symbol descriptions.

\begin{tabular}{|c|c|c|c|c|c|}
\hline \multicolumn{2}{|c|}{ ECEC } & \multirow{2}{*}{\multicolumn{2}{|c|}{$\frac{2009}{\text { Treatments }}$}} & \multirow{2}{*}{\multicolumn{2}{|c|}{$\frac{2019}{\text { Treatments }}$}} \\
\hline \multirow[t]{2}{*}{ Horizon } & \multirow[t]{2}{*}{ Paired Sites } & & & & \\
\hline & & Unlimed & To be Limed & Unlimed & Limed \\
\hline \multirow[t]{5}{*}{ B } & E509/509 & $4 \mathrm{c}$ & $6 a$ & $5 b$ & $6 c$ \\
\hline & $37 / 37-3$ & $9 a$ & $8 a$ & $10 \mathrm{a}$ & $10 a b$ \\
\hline & $31 / 37-2$ & $5 b c$ & $7 a$ & $8 a b^{\&}$ & $12 a * Y$ \\
\hline & $18 / 16$ & $5 \mathrm{bc}$ & $6 a$ & $7 a b$ & $6 c$ \\
\hline & $1 / 3$ & $8 a b$ & $7 a$ & $9 a$ & $8 b c$ \\
\hline \multicolumn{2}{|c|}{ Average Total } & $6 \pm 0.4$ & $7 \pm 0.4$ & $8 \pm 0.4^{U}$ & $8 \pm 0.4$ \\
\hline
\end{tabular}


Table 30. Average \% OM values (\%) in O horizons for sites sampled in the Terrestrial Liming Project. See footnotes in Table 21 for letter and symbol descriptions.

\begin{tabular}{|c|c|c|c|c|c|}
\hline \multicolumn{2}{|c|}{$\%$ OM } & \multicolumn{2}{c|}{2009} & \multicolumn{2}{c|}{2019} \\
\hline \multirow{3}{*}{ Horizon } & Paired Sites & \multicolumn{2}{c|}{ Treatments } & \multicolumn{2}{c|}{ Treatments } \\
\cline { 3 - 6 } & & Unlimed & To be Limed & Unlimed & Limed \\
\hline \multirow{4}{*}{0} & E509/509 & $42 \mathrm{bc}$ & $74 \mathrm{a}^{*}$ & $53 \mathrm{a}$ & $39 \mathrm{ab}^{\mathrm{Y}}$ \\
\cline { 2 - 6 } & $37 / 37-3$ & $81 \mathrm{a}$ & $70 \mathrm{a}$ & $64 \mathrm{a}$ & $21 \mathrm{~b}^{* \mathrm{Y}}$ \\
\cline { 2 - 6 } & $31 / 37-2$ & $60 \mathrm{ab}$ & $65 \mathrm{a}$ & $60 \mathrm{a}$ & $39 \mathrm{ab}^{\mathrm{Y}}$ \\
\cline { 2 - 6 } & $18 / 16$ & $29 \mathrm{c}$ & $71 \mathrm{a}^{*}$ & $46 \mathrm{a}^{\&}$ & $52 \mathrm{a}$ \\
\cline { 2 - 6 } & $1 / 3$ & $55 \mathrm{ab}$ & $58 \mathrm{a}$ & $72 \mathrm{a}$ & $31 \mathrm{ab}^{* \mathrm{Y}}$ \\
\hline \multicolumn{7}{|c|}{ Average Total } & $54 \pm 3$ & $68 \pm 3^{\#}$ & $58 \pm 3^{\mathrm{U}}$ & $35 \pm 3^{\# \mathrm{~L}}$ \\
\hline
\end{tabular}

Table 31. Average \% OM values (\%) in A horizons for sites sampled in the Terrestrial Liming Project. See footnotes in Table 21 for letter and symbol descriptions.

\begin{tabular}{|c|c|c|c|c|c|}
\hline \multicolumn{2}{|c|}{ \% OM } & \multicolumn{2}{c|}{2009} & \multicolumn{2}{c|}{2019} \\
\hline \multirow{3}{*}{ Horizon } & Paired Sites & \multicolumn{2}{c|}{ Treatments } & \multicolumn{2}{c|}{ Treatments } \\
\cline { 3 - 6 } & & Unlimed & To be Limed & Unlimed & Limed \\
\hline \multirow{4}{*}{$\mathrm{A}$} & E509/509 & $14 \mathrm{a}$ & $27 \mathrm{a}$ & $12 \mathrm{a}$ & $11 \mathrm{ab}^{\mathrm{Y}}$ \\
\cline { 2 - 6 } & $37 / 37-3$ & $25 \mathrm{a}$ & $12 \mathrm{a}$ & $12 \mathrm{a}^{*}$ & $8 \mathrm{~b}$ \\
\cline { 2 - 6 } & $31 / 37-2$ & $13 \mathrm{a}$ & $16 \mathrm{a}$ & $13 \mathrm{a}$ & $11 \mathrm{ab}$ \\
\cline { 2 - 6 } & $18 / 16$ & $15 \mathrm{a}$ & $16 \mathrm{a}$ & $13 \mathrm{a}$ & $9 \mathrm{ab}$ \\
\cline { 2 - 6 } & $1 / 3$ & $20 \mathrm{a}$ & $21 \mathrm{a}$ & $19 \mathrm{a}$ & $16 \mathrm{a}$ \\
\hline \multicolumn{2}{|c|}{ Average Total } & $17 \pm 2$ & $18 \pm 2$ & $14 \pm 1^{\mathrm{U}}$ & $11 \pm 1^{\text {\# }}$ \\
\hline
\end{tabular}

Table 32. Average \% OM values (\%) in B horizons for sites sampled in the Terrestrial Liming Project. See footnotes in Table 21 for letter and symbol descriptions.

\begin{tabular}{|c|c|c|c|c|c|}
\hline \multicolumn{2}{|c|}{ \% OM } & \multicolumn{2}{c|}{2009} & \multicolumn{2}{c|}{2019} \\
\hline \multirow{3}{*}{ Horizon } & Paired Sites & \multicolumn{2}{c|}{ Treatments } & \multicolumn{2}{c|}{ Treatments } \\
\cline { 3 - 6 } & & Unlimed & To be Limed & Unlimed & Limed \\
\hline \multirow{4}{*}{ B } & E509/509 & $8 \mathrm{a}$ & $13 \mathrm{a}$ & $5 \mathrm{a}^{\&}$ & $8 \mathrm{ab}$ \\
\cline { 2 - 6 } & $37 / 37-3$ & $10 \mathrm{a}$ & $7 \mathrm{a}$ & $8 \mathrm{a}$ & $7 \mathrm{ab}$ \\
\cline { 2 - 6 } & $31 / 37-2$ & $6 \mathrm{a}$ & $10 \mathrm{a}$ & $6 \mathrm{a}$ & $10 \mathrm{a}$ \\
\cline { 2 - 6 } & $18 / 16$ & $9 \mathrm{a}$ & $6 \mathrm{a}$ & $6 \mathrm{a}^{\&}$ & $5 \mathrm{~b}$ \\
\cline { 2 - 6 } & $1 / 3$ & $9 \mathrm{a}$ & $9 \mathrm{a}$ & $8 \mathrm{a}$ & $7 \mathrm{ab}$ \\
\hline \multicolumn{2}{|c|}{ Average Total } & $8 \pm 0.8$ & $9 \pm 0.8$ & $7 \pm 0.5^{\mathrm{U}}$ & $7 \pm 0.5$ \\
\hline
\end{tabular}

Table 33. Average \% TC values (\%) in O horizons for sites sampled in the Terrestrial Liming Project. See footnotes in Table 21 for letter and symbol descriptions. 


\begin{tabular}{|c|c|c|c|c|c|}
\hline \multirow{2}{*}{ \% TC } & \multicolumn{2}{c|}{2009} & \multicolumn{2}{c|}{2019} \\
\hline \multirow{3}{*}{ Horizon } & Paired Sites & \multicolumn{2}{c|}{ Treatments } & \multicolumn{2}{c|}{ Treatments } \\
\cline { 3 - 6 } & & Unlimed & To be Limed & Unlimed & Limed \\
\hline \multirow{3}{*}{0} & E509/509 & $22 \mathrm{ab}$ & $38 \mathrm{a}^{*}$ & $27 \mathrm{ab}$ & $22 \mathrm{ab}^{\mathrm{Y}}$ \\
\cline { 2 - 6 } & $37 / 37-3$ & $42 \mathrm{a}$ & $36 \mathrm{a}$ & $33 \mathrm{ab}$ & $12 \mathrm{~b}^{* \mathrm{Y}}$ \\
\cline { 2 - 6 } & $31 / 37-2$ & $31 \mathrm{ab}$ & $35 \mathrm{a}$ & $34 \mathrm{ab}$ & $20 \mathrm{ab}^{* \mathrm{Y}}$ \\
\cline { 2 - 6 } & $18 / 16$ & $14 \mathrm{c}$ & $38 \mathrm{a}^{*}$ & $24 \mathrm{~b}^{\&}$ & $28 \mathrm{a}$ \\
\cline { 2 - 6 } & $1 / 3$ & $29 \mathrm{ab}$ & $32 \mathrm{a}$ & $37 \mathrm{a}$ & $21 \mathrm{ab}^{* \mathrm{Y}}$ \\
\hline \multicolumn{7}{|c|}{ Average Total } & $28 \pm 2$ & $36 \pm 2^{\#}$ & $31 \pm 1$ & $20 \pm 1^{\# \mathrm{~L}}$ \\
\hline
\end{tabular}

Table 34. Average \% TC values (\%) in A horizons for sites sampled in the Terrestrial Liming Project. See footnotes in Table 21 for letter and symbol descriptions.

\begin{tabular}{|c|c|c|c|c|c|}
\hline \multicolumn{2}{|c|}{$\%$ TC } & \multicolumn{2}{c|}{2009} & \multicolumn{2}{c|}{2019} \\
\hline \multirow{3}{*}{ Horizon } & Paired Sites & \multicolumn{2}{c|}{ Treatments } & \multicolumn{2}{c|}{ Treatments } \\
\cline { 3 - 6 } & & Unlimed & To be Limed & Unlimed & Limed \\
\hline \multirow{4}{*}{ A } & E509/509 & $7 a$ & $14 a^{*}$ & $6 \mathrm{~b}$ & $5 \mathrm{ab}^{\mathrm{Y}}$ \\
\cline { 2 - 6 } & $37 / 37-3$ & $12 \mathrm{a}$ & $6 \mathrm{a}$ & $6 \mathrm{ab}$ & $4 \mathrm{~b}$ \\
\cline { 2 - 6 } & $31 / 37-2$ & $8 \mathrm{a}$ & $9 \mathrm{a}$ & $7 \mathrm{ab}$ & $6 \mathrm{ab}$ \\
\cline { 2 - 6 } & $18 / 16$ & $7 \mathrm{a}$ & $9 \mathrm{a}$ & $6 \mathrm{~b}$ & $5 \mathrm{ab}$ \\
\cline { 2 - 6 } & $1 / 3$ & $10 \mathrm{a}$ & $12 \mathrm{a}$ & $10 \mathrm{a}$ & $8 \mathrm{a}$ \\
\hline \multicolumn{7}{|c|}{ Average Total } & $9 \pm 1$ & $10 \pm 1$ & $7 \pm 0.4^{\mathrm{U}}$ & $6 \pm 0.4^{\mathrm{L}}$ \\
\hline
\end{tabular}

Table 35. Average \% TC values (\%) in B horizons for sites sampled in the Terrestrial Liming Project. See footnotes in Table 21 for letter and symbol descriptions.

\begin{tabular}{|c|c|c|c|c|c|}
\hline \multirow{2}{*}{$\%$ TC } & \multicolumn{2}{c|}{2009} & \multicolumn{2}{c|}{2019} \\
\hline \multirow{2}{*}{ Horizon } & Paired Sites & \multicolumn{2}{c|}{ Treatments } & \multicolumn{2}{c|}{ Treatments } \\
\cline { 3 - 6 } & & Unlimed & To be Limed & Unlimed & Limed \\
\hline \multirow{4}{*}{ B } & E509/509 & $4 \mathrm{a}$ & $6 \mathrm{a}$ & $2 \mathrm{a}^{\&}$ & $3 \mathrm{ab}^{\mathrm{Y}}$ \\
\cline { 2 - 6 } & $37 / 37-3$ & $4 \mathrm{a}$ & $2 \mathrm{~b}$ & $3 \mathrm{a}$ & $3 \mathrm{~b}$ \\
\cline { 2 - 6 } & $31 / 37-2$ & $3 \mathrm{a}$ & $5 \mathrm{ab}$ & $3 \mathrm{a}$ & $5 \mathrm{a}$ \\
\cline { 2 - 6 } & $18 / 16$ & $3 \mathrm{a}$ & $3 \mathrm{ab}$ & $2 \mathrm{a}^{\&}$ & $2 \mathrm{~b}$ \\
\cline { 2 - 6 } & $1 / 3$ & $4 \mathrm{a}$ & $3 \mathrm{ab}$ & $3 \mathrm{a}^{\&}$ & $2 \mathrm{~b}$ \\
\hline \multicolumn{2}{|c|}{ Average Total } & $3 \pm 0.4$ & $4 \pm 0.4$ & $2 \pm 0.2^{\mathrm{U}}$ & $3 \pm 0.2^{\#}$ \\
\hline
\end{tabular}

Table 36. Average \% TN values (\%) in O horizons for sites sampled in the Terrestrial Liming Project. See footnotes in Table 21 for letter and symbol descriptions.

\begin{tabular}{|c|c|c|c|c|c|}
\hline \multicolumn{2}{|c|}{$\%$ TN } & \multicolumn{2}{c|}{2009} & \multicolumn{2}{c|}{2019} \\
\hline \multirow{2}{*}{ Horizon } & \multirow{2}{*}{ Paired Sites } & \multicolumn{2}{c|}{ Treatments } & \multicolumn{2}{c|}{ Treatments } \\
\cline { 3 - 6 } & & Unlimed & To be Limed & Unlimed & Limed \\
\hline $\mathrm{O}$ & E509/509 & $1.2 \mathrm{~b}$ & $1.9 \mathrm{a}^{*}$ & $1.3 \mathrm{a}$ & $1.1 \mathrm{ab}^{\mathrm{Y}}$ \\
\hline
\end{tabular}




\begin{tabular}{|c|c|c|c|c|c|}
\hline \multirow{4}{*}{} & $37 / 37-3$ & $2.3 \mathrm{a}$ & $2.0 \mathrm{a}$ & $1.6 \mathrm{a}$ & $0.6 \mathrm{~b}^{* \mathrm{Y}}$ \\
\cline { 2 - 6 } & $31 / 37-2$ & $1.3 \mathrm{a}$ & $1.8 \mathrm{a}$ & $1.5 \mathrm{a}$ & $1.0 \mathrm{ab}^{\mathrm{Y}}$ \\
\cline { 2 - 6 } & $18 / 16$ & $0.9 \mathrm{~b}$ & $1.8 \mathrm{a}^{*}$ & $1.3 \mathrm{a}^{\&}$ & $1.5 \mathrm{a}$ \\
\cline { 2 - 6 } & $1 / 3$ & $1.4 \mathrm{~b}$ & $1.4 \mathrm{a}$ & $1.7 \mathrm{a}$ & $0.7 \mathrm{~b}^{* \mathrm{Y}}$ \\
\hline
\end{tabular}

Table 37. Average \% TN values (\%) in A horizons for sites sampled in the Terrestrial Liming Project. See footnotes in Table 21 for letter and symbol descriptions.

\begin{tabular}{|c|c|c|c|c|c|}
\hline \multicolumn{2}{|c|}{$\%$ TN } & \multicolumn{2}{c|}{2009} & \multicolumn{2}{c|}{2019} \\
\hline \multirow{3}{*}{ Horizon } & Paired Sites & \multicolumn{2}{c|}{ Treatments } & \multicolumn{2}{c|}{ Treatments } \\
\cline { 3 - 6 } & & Unlimed & To be Limed & Unlimed & Limed \\
\hline \multirow{4}{*}{ A } & E509/509 & $0.4 \mathrm{a}$ & $0.8 \mathrm{a}$ & $0.4 \mathrm{a}$ & $0.3 \mathrm{a}^{\mathrm{Y}}$ \\
\cline { 2 - 6 } & $37 / 37-3$ & $0.7 \mathrm{a}$ & $0.4 \mathrm{a}^{*}$ & $0.3 \mathrm{a}^{\&}$ & $0.2 \mathrm{a}$ \\
\cline { 2 - 6 } & $31 / 37-2$ & $0.4 \mathrm{a}$ & $0.5 \mathrm{a}$ & $0.3 \mathrm{a}$ & $0.3 \mathrm{a}$ \\
\cline { 2 - 6 } & $18 / 16$ & $0.5 \mathrm{a}$ & $0.5 \mathrm{a}$ & $0.4 \mathrm{a}$ & $0.3 \mathrm{a}$ \\
\cline { 2 - 6 } & $1 / 3$ & $0.5 \mathrm{a}$ & $0.6 \mathrm{a}$ & $0.5 \mathrm{a}$ & $0.4 \mathrm{a}$ \\
\hline \multicolumn{2}{|c|}{ Average Total } & $0.5 \pm 0.05$ & $0.5 \pm 0.05$ & $0.4 \pm 0.02^{\mathrm{U}}$ & $0.3 \pm 0.02^{\text {\# }}$ \\
\hline
\end{tabular}

Table 38. Average \% TN values (\%) in B horizons for sites sampled in the Terrestrial Liming Project. See footnotes in Table 21 for letter and symbol descriptions.

\begin{tabular}{|c|c|c|c|c|c|}
\hline \multicolumn{2}{|c|}{ \%TN } & \multicolumn{2}{c|}{2009} & \multicolumn{2}{c|}{2019} \\
\hline \multirow{3}{*}{ Horizon } & Paired Sites & \multicolumn{2}{c|}{ Treatments } & \multicolumn{2}{c|}{ Treatments } \\
\cline { 3 - 6 } & & Unlimed & To be Limed & Unlimed & Limed \\
\hline \multirow{3}{*}{ B } & E509/509 & $0.2 \mathrm{a}$ & $0.4 \mathrm{a}$ & $0.1 \mathrm{a}^{\&}$ & $0.2 \mathrm{ab}^{\mathrm{Y}}$ \\
\cline { 2 - 6 } & $37 / 37-3$ & $0.2 \mathrm{a}$ & $0.2 \mathrm{a}$ & $0.1 \mathrm{a}^{\&}$ & $0.2 \mathrm{ab}$ \\
\cline { 2 - 6 } & $31 / 37-2$ & $0.1 \mathrm{a}$ & $0.2 \mathrm{a}$ & $0.1 \mathrm{a}$ & $0.2 \mathrm{a}$ \\
\cline { 2 - 6 } & $18 / 16$ & $0.3 \mathrm{a}$ & $0.2 \mathrm{a}$ & $0.2 \mathrm{a}^{\&}$ & $0.1 \mathrm{~b}$ \\
\cline { 2 - 6 } & $1 / 3$ & $0.2 \mathrm{a}$ & $0.2 \mathrm{a}$ & $0.2 \mathrm{a}$ & $0.1 \mathrm{~b}$ \\
\hline \multicolumn{2}{|c|}{ Average Total } & $0.2 \pm 0.02$ & $0.2 \pm 0.02$ & $0.1 \pm 0.01^{\mathrm{U}}$ & $0.2 \pm 0.01^{\mathrm{L}}$ \\
\hline
\end{tabular}

Table 39. Average P values $(\mathrm{mg} / \mathrm{kg}$ ) in O horizons for sites sampled in the Terrestrial Liming Project. See footnotes in Table 21 for letter and symbol descriptions.

\begin{tabular}{|c|c|c|c|c|c|}
\hline \multicolumn{2}{|c|}{ P } & \multicolumn{2}{c|}{2009} & \multicolumn{2}{c|}{2019} \\
\hline Horizon & \multirow{2}{*}{ Paired Sites } & \multicolumn{2}{|c|}{ Treatments } & \multicolumn{2}{c|}{ Treatments } \\
\cline { 3 - 6 } & & Unlimed & To be Limed & Unlimed & Limed \\
\hline \multirow{5}{*}{0} & E509/509 & $31 \mathrm{bc}$ & $37 \mathrm{~b}$ & $38 \mathrm{a}$ & $15 \mathrm{~b}$ \\
\cline { 2 - 6 } & $37 / 37-3$ & $148 \mathrm{a}$ & $133 \mathrm{a}$ & $144 \mathrm{a}$ & $20 \mathrm{~b}^{*} \mathrm{Y}$ \\
\cline { 2 - 6 } & $31 / 37-2$ & $51 \mathrm{~b}$ & $67 \mathrm{ab}$ & $86 \mathrm{a}$ & $56 \mathrm{ab}$ \\
\cline { 2 - 6 } & $18 / 16$ & $12 \mathrm{c}$ & $81 \mathrm{ab}{ }^{*}$ & $34 \mathrm{a}$ & $126 \mathrm{a}$ \\
\cline { 2 - 6 } & $1 / 3$ & $37 \mathrm{bc}$ & $41 \mathrm{~b}$ & $72 \mathrm{a}$ & $44 \mathrm{ab}$ \\
\hline
\end{tabular}




\begin{tabular}{|l|c|c|c|c|}
\hline Average Total & $56 \pm 6$ & $72 \pm 6^{\#}$ & $69 \pm 10^{\cup}$ & $49 \pm 10^{\# \mathrm{~L}}$ \\
\hline
\end{tabular}

Table 40. Average P values $(\mathrm{mg} / \mathrm{kg}$ ) in A horizons for sites sampled in the Terrestrial Liming Project. See footnotes in Table 21 for letter and symbol descriptions.

\begin{tabular}{|c|c|c|c|c|c|}
\hline \multicolumn{2}{|c|}{ P } & \multicolumn{2}{c|}{2009} & \multicolumn{2}{c|}{2019} \\
\hline \multirow{3}{*}{ Horizon } & \multirow{2}{*}{ Paired Sites } & \multicolumn{2}{c|}{ Treatments } & \multicolumn{2}{c|}{ Treatments } \\
\cline { 3 - 6 } & & Unlimed & To be Limed & Unlimed & Limed \\
\hline \multirow{3}{*}{$\mathrm{A}$} & $\mathrm{E} 509 / 509$ & $3 \mathrm{~b}$ & $6 \mathrm{a}^{*}$ & $3 \mathrm{~b}$ & $3 \mathrm{a}$ \\
\cline { 2 - 6 } & $37 / 37-3$ & $9 \mathrm{a}$ & $6 \mathrm{a}^{*}$ & $5 \mathrm{a}^{\&}$ & $4 \mathrm{a}$ \\
\cline { 2 - 6 } & $31 / 37-2$ & $5 \mathrm{ab}$ & $5 \mathrm{a}$ & $4 \mathrm{ab}$ & $3 \mathrm{a}$ \\
\cline { 2 - 6 } & $18 / 16$ & $5 \mathrm{ab}$ & $7 \mathrm{a}$ & $4 \mathrm{ab}$ & $4 \mathrm{a}$ \\
\cline { 2 - 6 } & $1 / 3$ & $6 \mathrm{ab}$ & $7 \mathrm{a}$ & $5 \mathrm{ab}$ & $3 \mathrm{a}^{* \mathrm{Y}}$ \\
\cline { 2 - 6 } & $6 \pm 0.5$ & $6 \pm 0.5$ & $4 \pm 0.3^{\mathrm{U}}$ & $3 \pm 0.3^{\mathrm{L}}$ \\
\hline
\end{tabular}

Table 41. Average $P$ values $(\mathrm{mg} / \mathrm{kg}$ ) in B horizons for sites sampled in the Terrestrial Liming Project. See footnotes in Table 21 for letter and symbol descriptions.

\begin{tabular}{|c|c|c|c|c|c|}
\hline \multicolumn{2}{|c|}{$P$} & \multirow{2}{*}{\multicolumn{2}{|c|}{$\frac{2009}{\text { Treatments }}$}} & \multirow{2}{*}{\multicolumn{2}{|c|}{$\frac{2019}{\text { Treatments }}$}} \\
\hline \multirow[t]{2}{*}{ Horizon } & \multirow[t]{2}{*}{ Paired Sites } & & & & \\
\hline & & Unlimed & To be Limed & Unlimed & Limed \\
\hline \multirow[t]{5}{*}{ B } & E509/509 & $1 b$ & $2 a$ & $2 a b$ & $2 a$ \\
\hline & $37 / 37-3$ & $4 a$ & $3 a$ & $3 a$ & $2 a$ \\
\hline & $31 / 37-2$ & $2 b$ & $3 a *$ & $2 a b$ & $2 a$ \\
\hline & $18 / 16$ & $2 a b$ & $3 a$ & $1 a b$ & $0 \mathrm{~b} * \mathrm{Y}$ \\
\hline & $1 / 3$ & $3 a b$ & $3 a$ & $1 b^{\&}$ & $2 a^{Y}$ \\
\hline \multicolumn{2}{|c|}{ Average Total } & $2 \pm 0.2$ & $3 \pm 0.2$ & $2 \pm 0.1$ & $2 \pm 0.1^{L}$ \\
\hline
\end{tabular}

Table 42. Average $\mathrm{K}$ values $(\mathrm{cmol}+/ \mathrm{kg})$ in $\mathrm{O}$ horizons for sites sampled in the Terrestrial Liming Project. See footnotes in Table 21 for letter and symbol descriptions.

\begin{tabular}{|c|c|c|c|c|c|}
\hline \multicolumn{2}{|c|}{ K } & \multicolumn{2}{c|}{2009} & \multicolumn{2}{c|}{2019} \\
\hline \multirow{3}{*}{ Horizon } & Paired Sites & \multicolumn{2}{c|}{ Treatments } & \multicolumn{2}{c|}{ Treatments } \\
\cline { 3 - 6 } & & Unlimed & To be Limed & Unlimed & Limed \\
\hline \multirow{3}{*}{0} & E509/509 & $1.0 \mathrm{~b}$ & $2.0 \mathrm{a}$ & $1.0 \mathrm{~b}$ & $1.0 \mathrm{~b}^{\mathrm{Y}}$ \\
\cline { 2 - 6 } & $37 / 37-3$ & $3.0 \mathrm{a}$ & $2.5 \mathrm{a}$ & $1.5 \mathrm{ab} \&$ & $1.0 \mathrm{~b}^{* \mathrm{Y}}$ \\
\cline { 2 - 6 } & $31 / 37-2$ & $1.3 \mathrm{ab}$ & $1.3 \mathrm{a}$ & $1.4 \mathrm{ab}$ & $1.0 \mathrm{~b}^{*}$ \\
\cline { 2 - 6 } & $18 / 16$ & $1.0 \mathrm{~b}$ & $1.3 \mathrm{a}$ & $1.1 \mathrm{ab}$ & $2.0 \mathrm{a}^{*}$ \\
\cline { 2 - 6 } & $1 / 3$ & $2.0 \mathrm{ab}$ & $1.3 \mathrm{a}$ & $2.0 \mathrm{a}$ & $1.0 \mathrm{~b}^{* \mathrm{Y}}$ \\
\hline \multicolumn{2}{|c|}{ Average Total } & $1.5 \pm 0.15$ & $2.0 \pm 0.15$ & $1.3 \pm 0.05$ & $1.0 \pm 0.05^{\# \mathrm{~L}}$ \\
\hline
\end{tabular}

Table 43. Average $\mathrm{K}$ values (cmol+/ $\mathrm{kg}$ ) in A horizons for sites sampled in the Terrestrial Liming Project. See footnotes in Table 21 for letter and symbol descriptions. 


\begin{tabular}{|c|c|c|c|c|c|}
\hline \multicolumn{2}{|c|}{ K } & \multicolumn{2}{c|}{2009} & \multicolumn{2}{c|}{2019} \\
\hline \multirow{3}{*}{ Horizon } & Paired Sites & \multicolumn{2}{c|}{ Treatments } & \multicolumn{2}{c|}{ Treatments } \\
\cline { 3 - 6 } & & Unlimed & To be Limed & Unlimed & Limed \\
\hline \multirow{3}{*}{$\mathrm{A}$} & $\mathrm{E} 509 / 509$ & $0.17 \mathrm{~b}$ & $0.36 \mathrm{ab} \mathrm{b}^{*}$ & $0.21 \mathrm{~b}$ & $0.17 \mathrm{a}^{\mathrm{Y}}$ \\
\cline { 2 - 6 } & $37 / 37-3$ & $0.32 \mathrm{ab}$ & $0.19 \mathrm{~b}$ & $0.14 \mathrm{~b}^{\&}$ & $0.17 \mathrm{a}$ \\
\cline { 2 - 6 } & $31 / 37-2$ & $0.22 \mathrm{ab}$ & $0.19 \mathrm{~b}$ & $0.17 \mathrm{~b}$ & $0.20 \mathrm{a}$ \\
\cline { 2 - 6 } & $18 / 16$ & $0.34 \mathrm{ab}$ & $0.24 \mathrm{ab}$ & $0.30 \mathrm{ab}$ & $0.21 \mathrm{a}$ \\
\cline { 2 - 6 } & $1 / 3$ & $0.40 \mathrm{a}$ & $0.41 \mathrm{a}$ & $0.41 \mathrm{a}$ & $0.22 \mathrm{a} * \mathrm{Y}$ \\
\hline \multicolumn{2}{|c|}{ Average Total } & $0.29 \pm 0.023$ & $0.28 \pm 0.023$ & $0.25 \pm 0.021$ & $0.19 \pm 0.021^{\mathrm{L}}$ \\
\hline
\end{tabular}

Table 44. Average $\mathrm{K}$ values $(\mathrm{cmol}+/ \mathrm{kg})$ in B horizons for sites sampled in the Terrestrial Liming Project. See footnotes in Table 21 for letter and symbol descriptions.

\begin{tabular}{|c|c|c|c|c|c|}
\hline \multicolumn{2}{|c|}{ K } & \multicolumn{2}{c|}{2009} & \multicolumn{2}{c|}{2019} \\
\hline \multirow{3}{*}{ Horizon } & Paired Sites & \multicolumn{2}{c|}{ Treatments } & \multicolumn{2}{c|}{ Treatments } \\
\cline { 3 - 6 } & & Unlimed & To be Limed & Unlimed & Limed \\
\hline \multirow{3}{*}{$\mathrm{B}$} & E509/509 & $0.12 \mathrm{~b}$ & $0.2 \mathrm{a}$ & $0.12 \mathrm{ab}$ & $0.11 \mathrm{ab}$ \\
\cline { 2 - 6 } & $37 / 37-3$ & $0.13 \mathrm{~b}$ & $0.08 \mathrm{a}$ & $0.09 \mathrm{~b}$ & $0.14 \mathrm{ab}$ \\
\cline { 2 - 6 } & $31 / 37-2$ & $0.09 \mathrm{~b}$ & $0.08 \mathrm{a}$ & $0.08 \mathrm{~b}$ & $0.15 \mathrm{ab} *$ \\
\cline { 2 - 6 } & $18 / 16$ & $0.14 \mathrm{~b}$ & $0.11 \mathrm{a}$ & $0.13 \mathrm{ab}$ & $0.08 \mathrm{~b}$ \\
\cline { 2 - 6 } & $1 / 3$ & $0.22 \mathrm{a}$ & $0.16 \mathrm{a} *$ & $0.21 \mathrm{a}$ & $0.18 \mathrm{a}$ \\
\hline \multicolumn{2}{|c|}{ Average Total } & $0.14 \pm 0.008$ & $0.12 \pm 0.008$ & $0.12 \pm 0.010$ & $0.14 \pm 0.010$ \\
\hline
\end{tabular}

Table 45. Average Ca values ( $\mathrm{cmol}+/ \mathrm{kg}$ ) in O horizons for sites sampled in the Terrestrial Liming Project. See footnotes in Table 21 for letter and symbol descriptions.

\begin{tabular}{|c|c|c|c|c|c|}
\hline \multicolumn{2}{|c|}{ Ca } & \multicolumn{2}{c|}{2009} & \multicolumn{2}{c|}{2019} \\
\hline \multirow{3}{*}{ Horizon } & Paired Sites & \multicolumn{2}{c|}{ Treatments } & \multicolumn{2}{c|}{ Treatments } \\
\cline { 3 - 6 } & & Unlimed & To be Limed & Unlimed & Limed \\
\hline \multirow{3}{*}{0} & E509/509 & $4.3 \mathrm{~b}$ & $5.1 \mathrm{~b}$ & $3.8 \mathrm{c}$ & $14.8 \mathrm{~b}^{* \mathrm{Y}}$ \\
\cline { 2 - 6 } & $37 / 37-3$ & $18.1 \mathrm{a}$ & $15.1 \mathrm{a}$ & $9.6 \mathrm{ab}$ & $33.1 \mathrm{a}^{* \mathrm{Y}}$ \\
\cline { 2 - 6 } & $31 / 37-2$ & $6.6 \mathrm{ab}$ & $11.1 \mathrm{ab}$ & $7.0 \mathrm{~b}$ & $14.9 \mathrm{~b}^{*}$ \\
\cline { 2 - 6 } & $18 / 16$ & $11.3 \mathrm{a}$ & $9.3 \mathrm{ab}$ & $13.8 \mathrm{a}$ & $17.9 \mathrm{~b}^{\mathrm{Y}}$ \\
\cline { 2 - 6 } & $1 / 3$ & $6.4 \mathrm{ab}$ & $4.7 \mathrm{~b}$ & $5.9 \mathrm{bc}$ & $51.2 \mathrm{a}^{* \mathrm{Y}}$ \\
\hline \multicolumn{7}{|c|}{ Average Total } & $9.3 \pm 0.76$ & $9.1 \pm 0.76$ & $7.9 \pm 1.30$ & $27.2 \pm 1.28^{\# \mathrm{~L}}$ \\
\hline
\end{tabular}

Table 46. Average Ca values ( $\mathrm{cmol}+/ \mathrm{kg}$ ) in A horizons for sites sampled in the Terrestrial Liming Project. See footnotes in Table 21 for letter and symbol descriptions.

\begin{tabular}{|c|c|c|c|}
\hline \multicolumn{2}{|c|}{ Ca } & 2009 & 2019 \\
\hline Horizon & Paired Sites & Treatments & Treatments \\
\hline
\end{tabular}




\begin{tabular}{|c|c|c|c|c|c|}
\hline & & Unlimed & To be Limed & Unlimed & Limed \\
\hline \multirow[t]{5}{*}{ A } & E509/509 & $0.2 \mathrm{c}$ & $0.5 \mathrm{a}$ & $0.2 \mathrm{bc}$ & $0.7 c^{*}$ \\
\hline & $37 / 37-3$ & $1.0 \mathrm{ab}$ & $0.9 \mathrm{a}$ & $0.5 a b^{\&}$ & $3.7 a b * Y$ \\
\hline & $31 / 37-2$ & $0.3 \mathrm{bc}$ & $0.7 \mathrm{a}$ & $0.3 \mathrm{ab}$ & $2.2 b c^{*}$ \\
\hline & $18 / 16$ & $2.2 \mathrm{a}$ & $0.8 a^{*}$ & $0.9 a^{\&}$ & $1.0 \mathrm{c}$ \\
\hline & $1 / 3$ & $0.7 b c$ & $0.4 \mathrm{a}$ & $0.7 a b$ & $8.0 a^{* Y}$ \\
\hline \multicolumn{2}{|c|}{ Average Total } & $0.9 \pm 0.10$ & $0.7 \pm 0.10$ & $0.5 \pm 0.33^{U}$ & $3.2 \pm 0.33^{\# L}$ \\
\hline
\end{tabular}

Table 47. Average Ca values $(\mathrm{cmol}+\mathrm{kg}$ ) in B horizons for sites sampled in the Terrestrial Liming Project. See footnotes in Table 21 for letter and symbol descriptions.

\begin{tabular}{|c|c|c|c|c|c|}
\hline \multicolumn{2}{|c|}{ Ca } & \multicolumn{2}{c|}{2009} & \multicolumn{2}{c|}{2019} \\
\hline \multirow{3}{*}{ Horizon } & \multirow{2}{*}{ Paired Sites } & \multicolumn{2}{c|}{ Treatments } & \multicolumn{2}{c|}{ Treatments } \\
\cline { 3 - 6 } & & Unlimed & To be Limed & Unlimed & Limed \\
\hline \multirow{4}{*}{ B } & E509/509 & $0.1 \mathrm{~b}$ & $0.1 \mathrm{ab}$ & $0.1 \mathrm{~b}$ & $0.2 \mathrm{c}$ \\
\cline { 2 - 6 } & $37 / 37-3$ & $0.1 \mathrm{~b}$ & $0.2 \mathrm{a}^{*}$ & $0.1 \mathrm{~b}$ & $0.8 \mathrm{a}^{* \mathrm{Y}}$ \\
\cline { 2 - 6 } & $31 / 37-2$ & $0.1 \mathrm{~b}$ & $0.2 \mathrm{ab}^{*}$ & $0.1 \mathrm{ab}$ & $0.4 \mathrm{ab} *$ \\
\cline { 2 - 6 } & $18 / 16$ & $0.6 \mathrm{a}$ & $0.2 \mathrm{ab}^{*}$ & $0.2 \mathrm{a}^{*}$ & $0.2 \mathrm{bc}$ \\
\cline { 2 - 6 } & $1 / 3$ & $0.1 \mathrm{~b}$ & $0.1 \mathrm{bc}$ & $0.1 \mathrm{~b}$ & $0.5 \mathrm{a}^{* \mathrm{Y}}$ \\
\hline \multicolumn{2}{|c|}{ Average Total } & $0.2 \pm 0.05$ & $0.2 \pm 0.05$ & $0.1 \pm 0.04$ & $0.4 \pm 0.04^{\text {\# }}$ \\
\hline
\end{tabular}

Table 48. Average Mg values ( $\mathrm{cmol}+\mathrm{kg}$ ) in O horizons for sites sampled in the Terrestrial Liming Project. See footnotes in Table 21 for letter and symbol descriptions.

\begin{tabular}{|c|c|c|c|c|c|}
\hline \multicolumn{2}{|c|}{ Mg } & \multicolumn{2}{c|}{2009} & \multicolumn{2}{c|}{2019} \\
\hline \multirow{3}{*}{ Horizon } & Paired Sites & \multicolumn{2}{c|}{ Treatments } & \multicolumn{2}{c|}{ Treatments } \\
\cline { 3 - 6 } & & Unlimed & To be Limed & Unlimed & Limed \\
\hline \multirow{3}{*}{0} & E509/509 & $0.9 \mathrm{~b}$ & $1.4 \mathrm{~b}$ & $1.1 \mathrm{~b}^{\&}$ & $2.0 \mathrm{ab} *$ \\
\cline { 2 - 6 } & $37 / 37-3$ & $3.1 \mathrm{a}$ & $3.1 \mathrm{a}$ & $2.8 \mathrm{a}$ & $1.8 \mathrm{ab}$ \\
\cline { 2 - 6 } & $31 / 37-2$ & $1.8 \mathrm{a}$ & $2.0 \mathrm{ab}$ & $1.8 \mathrm{ab}$ & $1.5 \mathrm{~b}$ \\
\cline { 2 - 6 } & $18 / 16$ & $1.4 \mathrm{ab}$ & $2.0 \mathrm{ab}$ & $2.2 \mathrm{ab}$ & $3.6 \mathrm{a}$ \\
\cline { 2 - 6 } & $1 / 3$ & $1.6 \mathrm{a}$ & $1.5 \mathrm{ab}$ & $2.4 \mathrm{a}$ & $3.3 \mathrm{ab}$ \\
\hline \multicolumn{2}{|c|}{ Average Total } & $1.8 \pm 0.13$ & $2.0 \pm 0.13$ & $2.0 \pm 0.23^{\mathrm{U}}$ & $2.4 \pm 0.23$ \\
\hline
\end{tabular}

Table 49. Average $\mathrm{Mg}$ values $(\mathrm{cmol}+\mathrm{kg})$ in A horizons for sites sampled in the Terrestrial Liming Project. See footnotes in Table 21 for letter and symbol descriptions.

\begin{tabular}{|c|c|c|c|c|c|}
\hline \multicolumn{2}{|c|}{ Mg } & \multicolumn{2}{c|}{2009} & \multicolumn{2}{c|}{2019} \\
\hline \multirow{2}{*}{ Horizon } & Paired Sites & \multicolumn{2}{c|}{ Treatments } & \multicolumn{2}{c|}{ Treatments } \\
\cline { 3 - 6 } & & Unlimed & To be Limed & Unlimed & Limed \\
\hline \multirow{3}{*}{$\mathrm{A}$} & E509/509 & $0.13 \mathrm{~b}$ & $0.28 \mathrm{a}^{*}$ & $0.14 \mathrm{~b}$ & $0.20 \mathrm{~b}$ \\
\cline { 2 - 6 } & $37 / 37-3$ & $0.35 \mathrm{a}$ & $0.24 \mathrm{a}$ & $0.24 \mathrm{ab}$ \& & $0.37 \mathrm{ab}$ \\
\cline { 2 - 6 } & $31 / 37-2$ & $0.23 \mathrm{ab}$ & $0.24 \mathrm{a}$ & $0.24 \mathrm{ab}$ & $0.28 \mathrm{~b}$ \\
\hline
\end{tabular}




\begin{tabular}{|c|c|c|c|c|c|}
\hline & $18 / 16$ & $0.39 a$ & $0.28 \mathrm{a}$ & $0.32 \mathrm{ab}$ & $0.25 \mathrm{ab}$ \\
\cline { 2 - 6 } & $1 / 3$ & $0.34 \mathrm{a}$ & $0.3 \mathrm{a}$ & $0.47 \mathrm{a}$ & $0.73 \mathrm{a}$ \\
\hline \multicolumn{2}{|l|}{ Average Total } & $0.29 \pm 0.025$ & $0.30 \pm 0.025$ & $0.27 \pm 0.050$ & $0.38 \pm 0.050$ \\
\hline
\end{tabular}

Table 50. Average $\mathrm{Mg}$ values $(\mathrm{cmol}+\mathrm{kg})$ in B horizons for sites sampled in the Terrestrial Liming Project. See footnotes in Table 21 for letter and symbol descriptions.

\begin{tabular}{|c|c|c|c|c|c|}
\hline \multicolumn{2}{|c|}{ Mg } & \multicolumn{2}{c|}{2009} & \multicolumn{2}{c|}{2019} \\
\hline \multirow{3}{*}{ Horizon } & Paired Sites & \multicolumn{2}{c|}{ Treatments } & \multicolumn{2}{c|}{ Treatments } \\
\cline { 3 - 6 } & & Unlimed & To be Limed & Unlimed & Limed \\
\hline \multirow{4}{*}{ B } & E509/509 & $0.07 \mathrm{ab}$ & $0.13 \mathrm{a}$ & $0.07 \mathrm{a}$ & $0.13 \mathrm{ab}$ \\
\cline { 2 - 6 } & $37 / 37-3$ & $0.12 \mathrm{a}$ & $0.08 \mathrm{a}$ & $0.06 \mathrm{a}^{\&}$ & $0.17 \mathrm{a}{ }^{*} \mathrm{Y}$ \\
\cline { 2 - 6 } & $31 / 37-2$ & $0.04 \mathrm{~b}$ & $0.09 \mathrm{a}^{*}$ & $0.07 \mathrm{a}$ & $0.13 \mathrm{ab}^{*}$ \\
\cline { 2 - 6 } & $18 / 16$ & $0.10 \mathrm{a}$ & $0.06 \mathrm{a}$ & $0.10 \mathrm{a}$ & $0.08 \mathrm{~b}$ \\
\cline { 2 - 6 } & $1 / 3$ & $0.10 \mathrm{a}$ & $0.08 \mathrm{a}$ & $0.10 \mathrm{a}$ & $0.20 \mathrm{ab}^{\mathrm{Y}}$ \\
\hline \multicolumn{2}{|c|}{ Average Total } & $0.1 \pm 0.008$ & $0.1 \pm 0.008$ & $0.08 \pm 0.008$ & $0.1 \pm 0.008^{\text {\# }}$ \\
\hline
\end{tabular}

Table 51. Average Na values (cmol+/ $\mathrm{kg}$ ) in O horizons for sites sampled in the Terrestrial Liming Project. See footnotes in Table 21 for letter and symbol descriptions.

\begin{tabular}{|c|c|c|c|c|c|}
\hline \multicolumn{2}{|c|}{ Na } & \multicolumn{2}{c|}{2009} & \multicolumn{2}{c|}{2019} \\
\hline \multirow{3}{*}{ Horizon } & Paired Sites & \multicolumn{2}{c|}{ Treatments } & \multicolumn{2}{c|}{ Treatments } \\
\cline { 3 - 6 } & & Unlimed & To be Limed & Unlimed & Limed \\
\hline \multirow{3}{*}{$\mathrm{O}$} & E509/509 & $0.10 \mathrm{~b}$ & $0.18 \mathrm{ab}$ & $0.12 \mathrm{a}$ & $0.10 \mathrm{a}$ \\
\cline { 2 - 6 } & $37 / 37-3$ & $0.28 \mathrm{a}$ & $0.23 \mathrm{a}$ & $0.09 \mathrm{a}^{\&}$ & $0.06 \mathrm{a}^{\mathrm{Y}}$ \\
\cline { 2 - 6 } & $31 / 37-2$ & $0.13 \mathrm{~b}$ & $0.13 \mathrm{ab}$ & $0.13 \mathrm{a}$ & $0.10 \mathrm{a}$ \\
\cline { 2 - 6 } & $18 / 16$ & $0.12 \mathrm{~b}$ & $0.20 \mathrm{ab} *$ & $0.12 \mathrm{a}$ & $0.11 \mathrm{a}^{\mathrm{Y}}$ \\
\cline { 2 - 6 } & $1 / 3$ & $0.11 \mathrm{~b}$ & $0.10 \mathrm{~b}$ & $0.17 \mathrm{a}$ & $0.05 \mathrm{a}^{*}$ \\
\hline \multicolumn{2}{|c|}{ Average Total } & $0.15 \pm 0.013$ & $0.17 \pm 0.013$ & $0.13 \pm 0.013$ & $0.08 \pm 0.013^{\# \mathrm{~L}}$ \\
\hline
\end{tabular}

Table 52. Average Na values $(\mathrm{cmol}+/ \mathrm{kg})$ in A horizons for sites sampled in the Terrestrial Liming Project. See footnotes in Table 21 for letter and symbol descriptions.

\begin{tabular}{|c|c|c|c|c|c|}
\hline \multicolumn{2}{|c|}{ Na } & \multicolumn{2}{c|}{2009} & \multicolumn{2}{c|}{2019} \\
\hline \multirow{3}{*}{ Horizon } & Paired Sites & \multicolumn{2}{|c|}{ Treatments } & \multicolumn{2}{c|}{ Treatments } \\
\cline { 3 - 6 } & & Unlimed & To be Limed & Unlimed & Limed \\
\hline \multirow{3}{*}{$\mathrm{A}$} & $\mathrm{E} 509 / 509$ & $0.04 \mathrm{a}$ & $0.1 \mathrm{a}$ & $0.05 \mathrm{a}$ & $0.03 \mathrm{a}^{\mathrm{Y}}$ \\
\cline { 2 - 6 } & $37 / 37-3$ & $0.1 \mathrm{a}$ & $0.1 \mathrm{a}$ & $0.03 \mathrm{a}^{\&}$ & $0.03 \mathrm{a}^{\mathrm{Y}}$ \\
\cline { 2 - 6 } & $31 / 37-2$ & $0.05 \mathrm{a}$ & $0.1 \mathrm{a}$ & $0.03 \mathrm{a}$ & $0.01 \mathrm{a}^{\mathrm{Y}}$ \\
\cline { 2 - 6 } & $18 / 16$ & $0.1 \mathrm{a}$ & $0.1 \mathrm{a}$ & $0.04 \mathrm{a}^{\&}$ & $0.05 \mathrm{a}$ \\
\cline { 2 - 6 } & $1 / 3$ & $0.05 \mathrm{a}$ & $0.05 \mathrm{a}$ & $0.1 \mathrm{a}$ & $0.03 \mathrm{a}$ \\
\hline \multicolumn{2}{|c|}{ Average Total } & $0.1 \pm 0.01$ & $0.1 \pm 0.01$ & $0.04 \pm 0.004 \mathrm{U}$ & $0.03 \pm 0.004 \mathrm{~L}$ \\
\hline
\end{tabular}


Table 53. Average Na values $(\mathrm{cmol}+/ \mathrm{kg})$ in B horizons for sites sampled in the Terrestrial Liming Project. See footnotes in Table 21 for letter and symbol descriptions.

\begin{tabular}{|c|c|c|c|c|c|}
\hline \multicolumn{2}{|c|}{ Na } & \multicolumn{2}{c|}{2009} & \multicolumn{2}{c|}{2019} \\
\hline \multirow{3}{*}{ Horizon } & Paired Sites & \multicolumn{2}{c|}{ Treatments } & \multicolumn{2}{c|}{ Treatments } \\
\cline { 3 - 6 } & & Unlimed & To be Limed & Unlimed & Limed \\
\hline \multirow{4}{*}{$\mathrm{B}$} & $\mathrm{E} 509 / 509$ & $0.04 \mathrm{ab}$ & $0.05 \mathrm{a}$ & $0.03 \mathrm{a}$ & $0.03 \mathrm{a}$ \\
\cline { 2 - 6 } & $37 / 37-3$ & $0.1 \mathrm{a}$ & $0.05 \mathrm{a}$ & $0.04 \mathrm{a}$ & $0.01 \mathrm{a}^{\mathrm{Y}}$ \\
\cline { 2 - 6 } & $31 / 37-2$ & $0.02 \mathrm{~b}$ & $0.1 \mathrm{a}^{*}$ & $0.03 \mathrm{a}$ & $0.03 \mathrm{a}^{\mathrm{Y}}$ \\
\cline { 2 - 6 } & $18 / 16$ & $0.04 \mathrm{ab}$ & $0.03 \mathrm{a}$ & $0.03 \mathrm{a}$ & $0.03 \mathrm{a}$ \\
\cline { 2 - 6 } & $1 / 3$ & $0.03 \mathrm{ab}$ & $0.03 \mathrm{a}$ & $0.05 \mathrm{a}$ & $0.01 \mathrm{a}$ \\
\hline \multicolumn{2}{|c|}{ Average Total } & $0.04 \pm 0.004$ & $0.04 \pm 0.004$ & $0.03 \pm 0.004$ & $0.02 \pm 0.004 \mathrm{~L}$ \\
\hline
\end{tabular}

Table 54. Average Al values $(\mathrm{mg} / \mathrm{kg}$ ) in O horizons for sites sampled in the Terrestrial Liming Project. See footnotes in Table 21 for letter and symbol descriptions.

\begin{tabular}{|c|c|c|c|c|c|}
\hline \multicolumn{2}{|c|}{ Al } & \multicolumn{2}{c|}{2009} & \multicolumn{2}{c|}{2019} \\
\hline \multirow{3}{*}{ Horizon } & Paired Sites & \multicolumn{2}{|c|}{ Treatments } & \multicolumn{2}{c|}{ Treatments } \\
\cline { 3 - 6 } & & Unlimed & To be Limed & Unlimed & Limed \\
\hline \multirow{3}{*}{0} & E509/509 & $506 \mathrm{a}$ & $553 \mathrm{a}$ & $428 \mathrm{a}$ & $132 \mathrm{a}^{* \mathrm{Y}}$ \\
\cline { 2 - 6 } & $37 / 37-3$ & $39 \mathrm{c}$ & $53 \mathrm{~b}$ & $114 \mathrm{~b}$ & $18 \mathrm{a}$ \\
\cline { 2 - 6 } & $31 / 37-2$ & $175 \mathrm{bc}$ & $93 \mathrm{~b}$ & $293 \mathrm{a}$ & $87 \mathrm{a}$ \\
\cline { 2 - 6 } & $18 / 16$ & $225 \mathrm{abc}$ & $141 \mathrm{~b}$ & $94 \mathrm{~b}$ & $36 \mathrm{a}$ \\
\cline { 2 - 6 } & $1 / 3$ & $431 \mathrm{ab}$ & $518 \mathrm{a}$ & $319 \mathrm{a}$ & $21 \mathrm{a} * \mathrm{Y}$ \\
\cline { 2 - 6 } & $275 \pm 33$ & $272 \pm 33$ & $261 \pm 17$ & $58 \pm 17^{\# \mathrm{~L}}$ \\
\hline
\end{tabular}

Table 55. Average Al values $(\mathrm{mg} / \mathrm{kg}$ ) in A horizons for sites sampled in the Terrestrial Liming Project. See footnotes in Table 21 for letter and symbol descriptions.

\begin{tabular}{|c|c|c|c|c|c|}
\hline \multicolumn{2}{|r|}{$\mathrm{Al}$} & \multirow{2}{*}{\multicolumn{2}{|c|}{$\begin{array}{c}2009 \\
\text { Treatments }\end{array}$}} & \multirow{2}{*}{\multicolumn{2}{|c|}{$\frac{2019}{\text { Treatments }}$}} \\
\hline \multirow[t]{2}{*}{ Horizon } & \multirow[t]{2}{*}{ Paired Sites } & & & & \\
\hline & & Unlimed & To be Limed & Unlimed & Limed \\
\hline \multirow[t]{5}{*}{ A } & E509/509 & $505 \mathrm{~b}$ & $734 a b$ & $453 \mathrm{~b}$ & $383 a^{Y}$ \\
\hline & $37 / 37-3$ & $593 a b$ & $533 \mathrm{~b}$ & $535 b$ & 265 a * \\
\hline & $31 / 37-2$ & $435 b$ & $536 \mathrm{~b}$ & $581 \mathrm{~b}$ & $385 a$ \\
\hline & $18 / 16$ & $412 b$ & $459 \mathrm{~b}$ & $541 \mathrm{~b}$ & $301 a^{*}$ \\
\hline & $1 / 3$ & $976 \mathrm{a}$ & $972 a$ & $1,022 \mathrm{a}$ & $286 a * \mathrm{Y}$ \\
\hline \multicolumn{2}{|c|}{ Average Total } & $584 \pm 44$ & $647 \pm 44$ & $627 \pm 31$ & $325 \pm 32$ \# L \\
\hline
\end{tabular}

Table 56. Average Al values $(\mathrm{mg} / \mathrm{kg}$ ) in B horizons for sites sampled in the Terrestrial Liming Project. See footnotes in Table 21 for letter and symbol descriptions. 


\begin{tabular}{|c|c|c|c|c|c|}
\hline \multicolumn{2}{|c|}{ Al } & \multicolumn{2}{c|}{2009} & \multicolumn{2}{c|}{2019} \\
\hline \multirow{3}{*}{ Horizon } & Paired Sites & \multicolumn{2}{c|}{ Treatments } & \multicolumn{2}{c|}{ Treatments } \\
\cline { 3 - 6 } & & Unlimed & To be Limed & Unlimed & Limed \\
\hline \multirow{4}{*}{ B } & E509/509 & $321 \mathrm{~b}$ & $462 \mathrm{a}$ & $335 \mathrm{a}$ & $308 \mathrm{~b}$ \\
\cline { 2 - 6 } & $37 / 37-3$ & $703 \mathrm{a}$ & $591 \mathrm{a}$ & $519 \mathrm{a}^{\&}$ & $682 \mathrm{a}^{\mathrm{Y}}$ \\
\cline { 2 - 6 } & $31 / 37-2$ & $327 \mathrm{~b}$ & $524 \mathrm{a}$ & $518 \mathrm{a}^{\&}$ & $759 \mathrm{a}^{*}$ \\
\cline { 2 - 6 } & $18 / 16$ & $323 \mathrm{~b}$ & $454 \mathrm{a}$ & $381 \mathrm{a}$ & $337 \mathrm{~b}$ \\
\cline { 2 - 6 } & $1 / 3$ & $630 \mathrm{ab}$ & $517 \mathrm{a}$ & $565 \mathrm{a}$ & $409 \mathrm{~b}$ \\
\hline \multicolumn{2}{|c|}{ Average Total } & $461 \pm 36$ & $510 \pm 36$ & $464 \pm 27$ & $506 \pm 28$ \\
\hline
\end{tabular}

Table 57. Average Fe values $(\mathrm{mg} / \mathrm{kg}$ ) in O horizons for sites sampled in the Terrestrial Liming Project. See footnotes in Table 21 for letter and symbol descriptions.

\begin{tabular}{|c|c|c|c|c|c|}
\hline \multicolumn{2}{|c|}{ Fe } & \multicolumn{2}{c|}{2009} & \multicolumn{2}{c|}{2019} \\
\hline \multirow{3}{*}{ Horizon } & \multirow{2}{*}{ Paired Sites } & \multicolumn{2}{c|}{ Treatments } & \multicolumn{2}{c|}{ Treatments } \\
\cline { 3 - 6 } & & Unlimed & To be Limed & Unlimed & Limed \\
\hline \multirow{4}{*}{0} & E509/509 & $45 \mathrm{a}$ & $14 \mathrm{bc}^{*}$ & $60 \mathrm{a}$ & $12 \mathrm{ab}^{*}$ \\
\cline { 2 - 6 } & $37 / 37-3$ & $8 \mathrm{c}$ & $8 \mathrm{c}$ & $40 \mathrm{a}^{\&}$ & $7 \mathrm{~b}^{*}$ \\
\cline { 2 - 6 } & $31 / 37-2$ & $28 \mathrm{ab}$ & $23 \mathrm{abc}$ & $50 \mathrm{a}$ & $25 \mathrm{a}^{*}$ \\
\cline { 2 - 6 } & $18 / 16$ & $8 \mathrm{bc}$ & $29 \mathrm{ab} *$ & $12 \mathrm{~b}$ & $10 \mathrm{ab}^{\mathrm{Y}}$ \\
\cline { 2 - 6 } & $1 / 3$ & $38 \mathrm{a}$ & $53 \mathrm{a}$ & $78 \mathrm{a}^{\&}$ & $6 \mathrm{~b}^{* \mathrm{Y}}$ \\
\hline \multicolumn{2}{|c|}{ Average Total } & $25 \pm 3$ & $25 \pm 3$ & $49 \pm 4^{\mathrm{U}}$ & $12 \pm 4^{\text {\# }}$ \\
\hline
\end{tabular}

Table 58. Average Fe values $(\mathrm{mg} / \mathrm{kg}$ ) in A horizons for sites sampled in the Terrestrial Liming Project. See footnotes in Table 21 for letter and symbol descriptions.

\begin{tabular}{|c|c|c|c|c|c|}
\hline \multicolumn{2}{|c|}{ Fe } & \multicolumn{2}{c|}{2009} & \multicolumn{2}{c|}{2019} \\
\hline \multirow{3}{*}{ Horizon } & Paired Sites & \multicolumn{2}{c|}{ Treatments } & \multicolumn{2}{c|}{ Treatments } \\
\cline { 3 - 6 } & & Unlimed & To be Limed & Unlimed & Limed \\
\hline \multirow{3}{*}{$\mathrm{A}$} & $\mathrm{E} 509 / 509$ & $13 \mathrm{bc}$ & $23 \mathrm{a}$ & $12 \mathrm{~b}$ & $19 \mathrm{a}$ \\
\cline { 2 - 6 } & $37 / 37-3$ & $68 \mathrm{a}$ & $30 \mathrm{a}^{*}$ & $74 \mathrm{a}$ & $26 \mathrm{a}^{*}$ \\
\cline { 2 - 6 } & $31 / 37-2$ & $41 \mathrm{ab}$ & $53 \mathrm{a}$ & $50 \mathrm{a}$ & $47 \mathrm{a}$ \\
\cline { 2 - 6 } & $18 / 16$ & $3 \mathrm{c}$ & $42 \mathrm{a}^{*}$ & $6 \mathrm{~b}$ & $17 \mathrm{a}$ \\
\cline { 2 - 6 } & $1 / 3$ & $24 \mathrm{ab}$ & $54 \mathrm{a}$ & $79 \mathrm{a}^{\&}$ & $31 \mathrm{a}^{*}$ \\
\hline \multicolumn{2}{|c|}{ Average Total } & $30 \pm 5$ & $40 \pm 5$ & $44 \pm 5^{\mathrm{U}}$ & $29 \pm 5$ \\
\hline
\end{tabular}

Table 59. Average Fe values $(\mathrm{mg} / \mathrm{kg}$ ) in B horizons for sites sampled in the Terrestrial Liming Project. See footnotes in Table 21 for letter and symbol descriptions.

\begin{tabular}{|c|c|c|c|c|c|}
\hline \multicolumn{2}{|c|}{ Fe } & \multicolumn{2}{c|}{2009} & \multicolumn{2}{c|}{2019} \\
\hline \multirow{2}{*}{ Horizon } & Paired Sites & \multicolumn{2}{c|}{ Treatments } & \multicolumn{2}{c|}{ Treatments } \\
\cline { 3 - 6 } & & Unlimed & To be Limed & Unlimed & Limed \\
\hline B & E509/509 & $8 \mathrm{~b}$ & $8 \mathrm{a}$ & $6 \mathrm{bc}$ & $7 \mathrm{c}$ \\
\hline
\end{tabular}




\begin{tabular}{|c|c|c|c|c|c|}
\hline & $37 / 37-3$ & $26 a$ & $9 a^{*}$ & $31 \mathrm{a}$ & $32 a b^{Y}$ \\
\hline & $31 / 37-2$ & $12 a b$ & $25 \mathrm{a}$ & $21 \mathrm{a}$ & $57 a * Y$ \\
\hline & $18 / 16$ & $2 b$ & $19 a^{*}$ & $3 c$ & $9 \mathrm{bc} *$ \\
\hline & $1 / 3$ & $4 a b$ & $7 a$ & $10 a b$ & $33 a b * Y$ \\
\hline \multicolumn{2}{|c|}{ Average Total } & $11 \pm 3$ & $14 \pm 3$ & $14 \pm 3^{U}$ & $28 \pm 3^{\# L}$ \\
\hline
\end{tabular}

Table 60. Average Mn values ( $\mathrm{mg} / \mathrm{kg}$ ) in O horizons for sites sampled in the Terrestrial Liming Project. See footnotes in Table 21 for letter and symbol descriptions.

\begin{tabular}{|c|c|c|c|c|c|}
\hline \multicolumn{2}{|c|}{ Mn } & \multicolumn{2}{c|}{2009} & \multicolumn{2}{c|}{2019} \\
\hline \multirow{3}{*}{ Horizon } & Paired Sites & \multicolumn{2}{c|}{ Treatments } & \multicolumn{2}{c|}{ Treatments } \\
\cline { 2 - 6 } & & Unlimed & To be Limed & Unlimed & Limed \\
\hline \multirow{3}{*}{0} & E509/509 & $275 a b$ & $420 \mathrm{~b}$ & $416 \mathrm{~b}^{\&}$ & $287 \mathrm{~b}$ \\
\cline { 2 - 6 } & $37 / 37-3$ & $475 \mathrm{a}$ & $1032 \mathrm{a}^{*}$ & $400 \mathrm{ab}$ & $114 \mathrm{bc} * \mathrm{Y}$ \\
\cline { 2 - 6 } & $31 / 37-2$ & $167 \mathrm{~b}$ & $297 \mathrm{~b}$ & $134 \mathrm{c}$ & $190 \mathrm{bc}$ \\
\cline { 2 - 6 } & $18 / 16$ & $289 \mathrm{ab}$ & $313 \mathrm{~b}$ & $1098 \mathrm{a}^{\text {\& }}$ & $1483 \mathrm{a}^{\mathrm{Y}}$ \\
\cline { 2 - 6 } & $1 / 3$ & $344 \mathrm{ab}$ & $209 \mathrm{~b}$ & $468 \mathrm{ab}$ & $84 \mathrm{c}^{* \mathrm{Y}}$ \\
\hline \multicolumn{2}{|c|}{ Average Total } & $310 \pm 36$ & $454 \pm 36$ & $512 \pm 53^{\mathrm{U}}$ & $397 \pm 52^{\# \mathrm{~L}}$ \\
\hline
\end{tabular}

Table 61. Average Mn values $(\mathrm{mg} / \mathrm{kg}$ ) in A horizons for sites sampled in the Terrestrial Liming Project. See footnotes in Table 21 for letter and symbol descriptions.

\begin{tabular}{|c|c|c|c|c|c|}
\hline \multicolumn{2}{|c|}{ Mn } & \multicolumn{2}{c|}{2009} & \multicolumn{2}{c|}{2019} \\
\hline \multirow{3}{*}{ Horizon } & Paired Sites & \multicolumn{2}{c|}{ Treatments } & \multicolumn{2}{c|}{ Treatments } \\
\cline { 3 - 6 } & & Unlimed & To be Limed & Unlimed & Limed \\
\hline \multirow{3}{*}{ A } & E509/509 & $39 \mathrm{ab}$ & $157 \mathrm{a}$ & $56 \mathrm{a}$ & $50 \mathrm{a}$ \\
\cline { 2 - 6 } & $37 / 37-3$ & $22 \mathrm{~b}$ & $79 \mathrm{a}^{*}$ & $10 \mathrm{~b}^{\&}$ & $87 \mathrm{a}^{*}$ \\
\cline { 2 - 6 } & $31 / 37-2$ & $5 \mathrm{c}$ & $19 \mathrm{~b}^{*}$ & $4 \mathrm{~b}$ & $31 \mathrm{a}^{*}$ \\
\cline { 2 - 6 } & $18 / 16$ & $123 \mathrm{a}$ & $18 \mathrm{~b}^{*}$ & $212 \mathrm{a}$ & $138 \mathrm{a}^{\mathrm{Y}}$ \\
\cline { 2 - 6 } & $1 / 3$ & $48 \mathrm{ab}$ & $20 \mathrm{ab}$ & $155 \mathrm{a}$ & $29 \mathrm{a}$ \\
\hline \multicolumn{2}{|c|}{ Average Total } & $48 \pm 17$ & $59 \pm 17$ & $88 \pm 19$ & $64 \pm 20$ \\
\hline
\end{tabular}

Table 62. Average Mn values $(\mathrm{mg} / \mathrm{kg}$ ) in B horizons for sites sampled in the Terrestrial Liming Project. See footnotes in Table 21 for letter and symbol descriptions.

\begin{tabular}{|c|c|c|c|c|c|}
\hline \multicolumn{2}{|c|}{ Mn } & \multicolumn{2}{c|}{2009} & \multicolumn{2}{c|}{2019} \\
\hline \multirow{3}{*}{ Horizon } & \multirow{2}{*}{ Paired Sites } & \multicolumn{2}{|c|}{ Treatments } & \multicolumn{2}{c|}{ Treatments } \\
\cline { 3 - 6 } & & Unlimed & To be Limed & Unlimed & Limed \\
\hline \multirow{4}{*}{ B } & E509/509 & $10 \mathrm{ab}$ & $34 \mathrm{a}$ & $15 \mathrm{a}$ & $18 \mathrm{ab}$ \\
\cline { 2 - 6 } & $37 / 37-3$ & $4 \mathrm{~b}$ & $18 \mathrm{ab} *$ & $3 \mathrm{~b}$ & $69 \mathrm{a}^{*}$ \\
\cline { 2 - 6 } & $31 / 37-2$ & $1 \mathrm{c}$ & $6 \mathrm{bc}^{*}$ & $1 \mathrm{c}$ & $10 \mathrm{ab}^{*}$ \\
\cline { 2 - 6 } & $18 / 16$ & $20 \mathrm{a}$ & $3 \mathrm{c}^{*}$ & $36 \mathrm{a}$ & $11 \mathrm{ab}^{* \mathrm{Y}}$ \\
\cline { 2 - 6 } & $1 / 3$ & $13 \mathrm{ab}$ & $6 \mathrm{bc}$ & $38 \mathrm{a}^{*}$ & $4 \mathrm{~b}^{*}$ \\
\hline
\end{tabular}


Table 63. Average $\mathrm{Zn}$ values $(\mathrm{mg} / \mathrm{kg}$ ) in O horizons for sites sampled in the Terrestrial Liming Project. See footnotes in Table 21 for letter and symbol descriptions.

\begin{tabular}{|c|c|c|c|c|c|}
\hline \multicolumn{2}{|c|}{ Zn } & \multicolumn{2}{c|}{2009} & \multicolumn{2}{c|}{2019} \\
\hline \multirow{3}{*}{ Horizon } & Paired Sites & \multicolumn{2}{c|}{ Treatments } & \multicolumn{2}{c|}{ Treatments } \\
\cline { 3 - 6 } & & Unlimed & To be Limed & Unlimed & Limed \\
\hline \multirow{4}{*}{0} & E509/509 & $9 \mathrm{~b}$ & $15 \mathrm{a}^{*}$ & $13 \mathrm{ab}^{\&}$ & $5 \mathrm{~b}^{* \mathrm{Y}}$ \\
\cline { 2 - 6 } & $37 / 37-3$ & $16 \mathrm{ab}$ & $13 \mathrm{a}$ & $29 \mathrm{a}$ & $0 \mathrm{c}^{* \mathrm{Y}}$ \\
\cline { 2 - 6 } & $31 / 37-2$ & $15 \mathrm{ab}$ & $12 \mathrm{a}$ & $21 \mathrm{ab}$ & $7 \mathrm{ab}^{* \mathrm{Y}}$ \\
\cline { 2 - 6 } & $18 / 16$ & $15 \mathrm{ab}$ & $25 \mathrm{a}$ & $13 \mathrm{~b}$ & $13 \mathrm{a}^{\mathrm{Y}}$ \\
\cline { 2 - 6 } & $1 / 3$ & $18 \mathrm{a}$ & $19 \mathrm{a}$ & $23 \mathrm{ab}$ & $0 \mathrm{c}^{* \mathrm{Y}}$ \\
\hline \multicolumn{7}{|c|}{ Average Total } & $15 \pm 1$ & $17 \pm 1$ & $19 \pm 1^{\mathrm{U}}$ & $5 \pm 1^{\text {\# }}$ \\
\hline
\end{tabular}

Table 64. Average $\mathrm{Zn}$ values $(\mathrm{mg} / \mathrm{kg}$ ) in A horizons for sites sampled in the Terrestrial Liming Project. See footnotes in Table 21 for letter and symbol descriptions.

\begin{tabular}{|c|c|c|c|c|c|}
\hline \multicolumn{2}{|c|}{ Zn } & \multicolumn{2}{c|}{2009} & \multicolumn{2}{c|}{2019} \\
\hline \multirow{3}{*}{ Horizon } & \multirow{2}{*}{ Paired Sites } & \multicolumn{2}{c|}{ Treatments } & \multicolumn{2}{c|}{ Treatments } \\
\cline { 3 - 6 } & & Unlimed & To be Limed & Unlimed & Limed \\
\hline \multirow{4}{*}{$\mathrm{A}$} & E509/509 & $1.9 \mathrm{~b}$ & $4.0 \mathrm{ab}$ & $2.1 \mathrm{~b}^{\&}$ & $1.8 \mathrm{a}^{\mathrm{Y}}$ \\
\cline { 2 - 6 } & $37 / 37-3$ & $4.2 \mathrm{ab}$ & $1.5 \mathrm{~b}$ & $2.1 \mathrm{~b}$ & $2.0 \mathrm{a}$ \\
\cline { 2 - 6 } & $31 / 37-2$ & $2.9 \mathrm{ab}$ & $2.5 \mathrm{ab}$ & $2.8 \mathrm{ab}$ & $2.7 \mathrm{a}$ \\
\cline { 2 - 6 } & $18 / 16$ & $10.1 \mathrm{a}$ & $4.7 \mathrm{a}$ & $2.2 \mathrm{~b}^{\&}$ & $1.6 \mathrm{a}^{\mathrm{Y}}$ \\
\cline { 2 - 6 } & $1 / 3$ & $4.8 \mathrm{ab}$ & $6.0 \mathrm{a}$ & $6.3 \mathrm{a}$ & $2.9 \mathrm{a}^{* \mathrm{Y}}$ \\
\hline \multicolumn{7}{|c|}{ Average Total } & $4.8 \pm 0.82$ & $3.8 \pm 0.82$ & $3.1 \pm 0.36^{\mathrm{U}}$ & $2.2 \pm 0.37^{\mathrm{L}}$ \\
\hline
\end{tabular}

Table 65. Average $\mathrm{Zn}$ values $(\mathrm{mg} / \mathrm{kg}$ ) in B horizons for sites sampled in the Terrestrial Liming Project. See footnotes in Table 21 for letter and symbol descriptions.

\begin{tabular}{|c|c|c|c|c|c|}
\hline \multirow{2}{*}{ Zn } & \multicolumn{2}{c|}{2009} & \multicolumn{2}{c|}{2019} \\
\hline \multirow{3}{*}{ Horizon } & Paired Sites & \multicolumn{2}{c|}{ Treatments } & \multicolumn{2}{c|}{ Treatments } \\
\cline { 3 - 6 } & & Unlimed & To be Limed & Unlimed & Limed \\
\hline \multirow{4}{*}{$\mathrm{B}$} & E509/509 & $0.8 \mathrm{~b}$ & $1.6 \mathrm{ab} \mathrm{b}^{*}$ & $0.9 \mathrm{ab}$ & $0.9 \mathrm{ab}$ \\
\cline { 2 - 6 } & $37 / 37-3$ & $0.5 \mathrm{~b}$ & $0.6 \mathrm{~b}$ & $1.3 \mathrm{a}^{\&}$ & $1.0 \mathrm{a}$ \\
\cline { 2 - 6 } & $31 / 37-2$ & $1.1 \mathrm{ab}$ & $1.3 \mathrm{ab}$ & $1.0 \mathrm{ab}$ & $1.4 \mathrm{a}$ \\
\cline { 2 - 6 } & $18 / 16$ & $1.3 \mathrm{ab}$ & $2.0 \mathrm{a}$ & $0.5 \mathrm{~b}^{\&}$ & $0.3 \mathrm{~b}^{\mathrm{Y}}$ \\
\cline { 2 - 6 } & $1 / 3$ & $2.0 \mathrm{a}$ & $2.0 \mathrm{a}$ & $1.4 \mathrm{a}$ & $1.0 \mathrm{a}^{\mathrm{Y}}$ \\
\hline \multicolumn{2}{|c|}{ Average Total } & $1.1 \pm 0.14$ & $1.5 \pm 0.14$ & $1.0 \pm 0.09$ & $1.0 \pm 0.09^{\mathrm{L}}$ \\
\hline
\end{tabular}




\section{Appendix 2 - Examples of Soil Profiles in the MNF.}

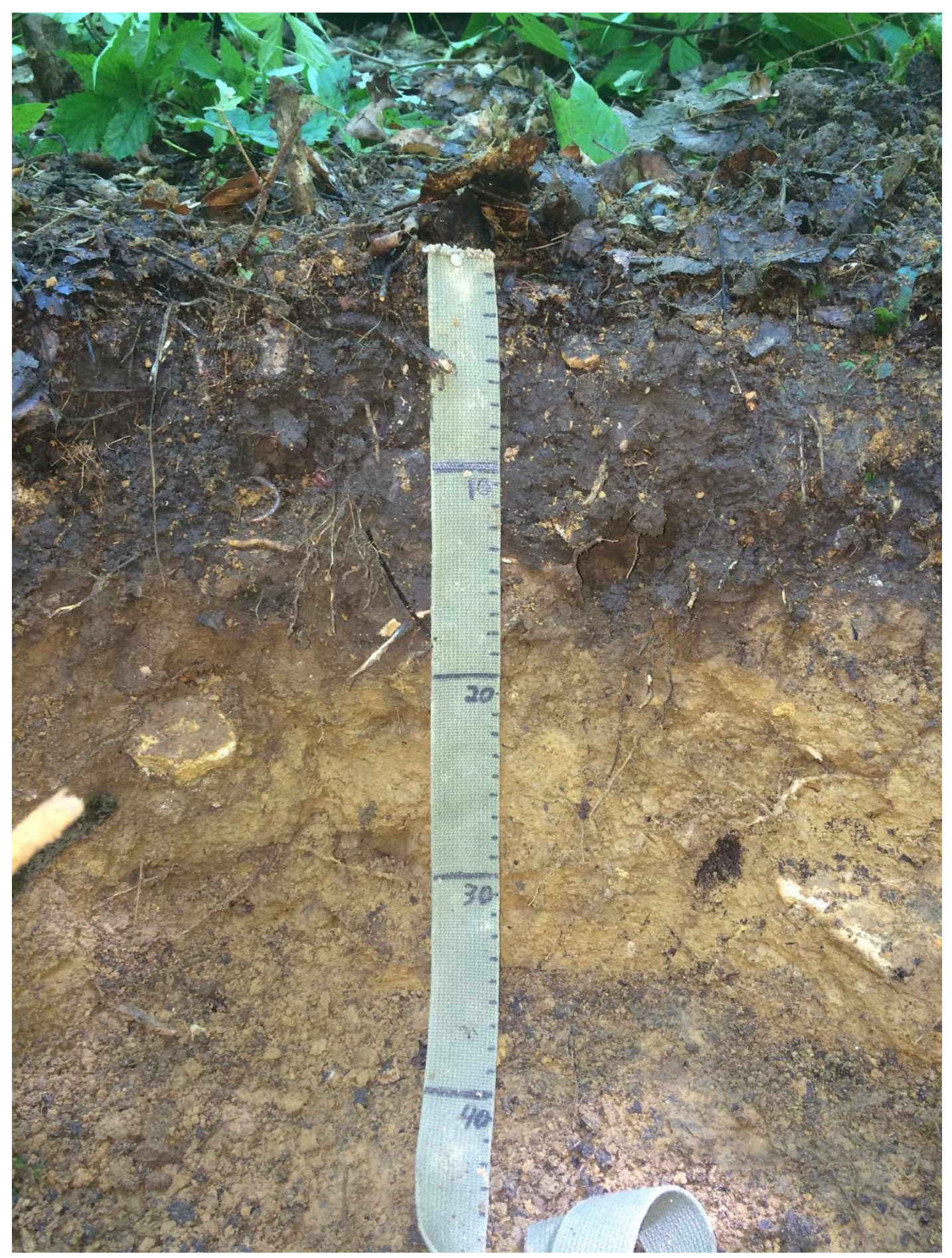

Figure 26. Soil sampling pit profile of Site 37 (Unlimed) (Pit \#5). 


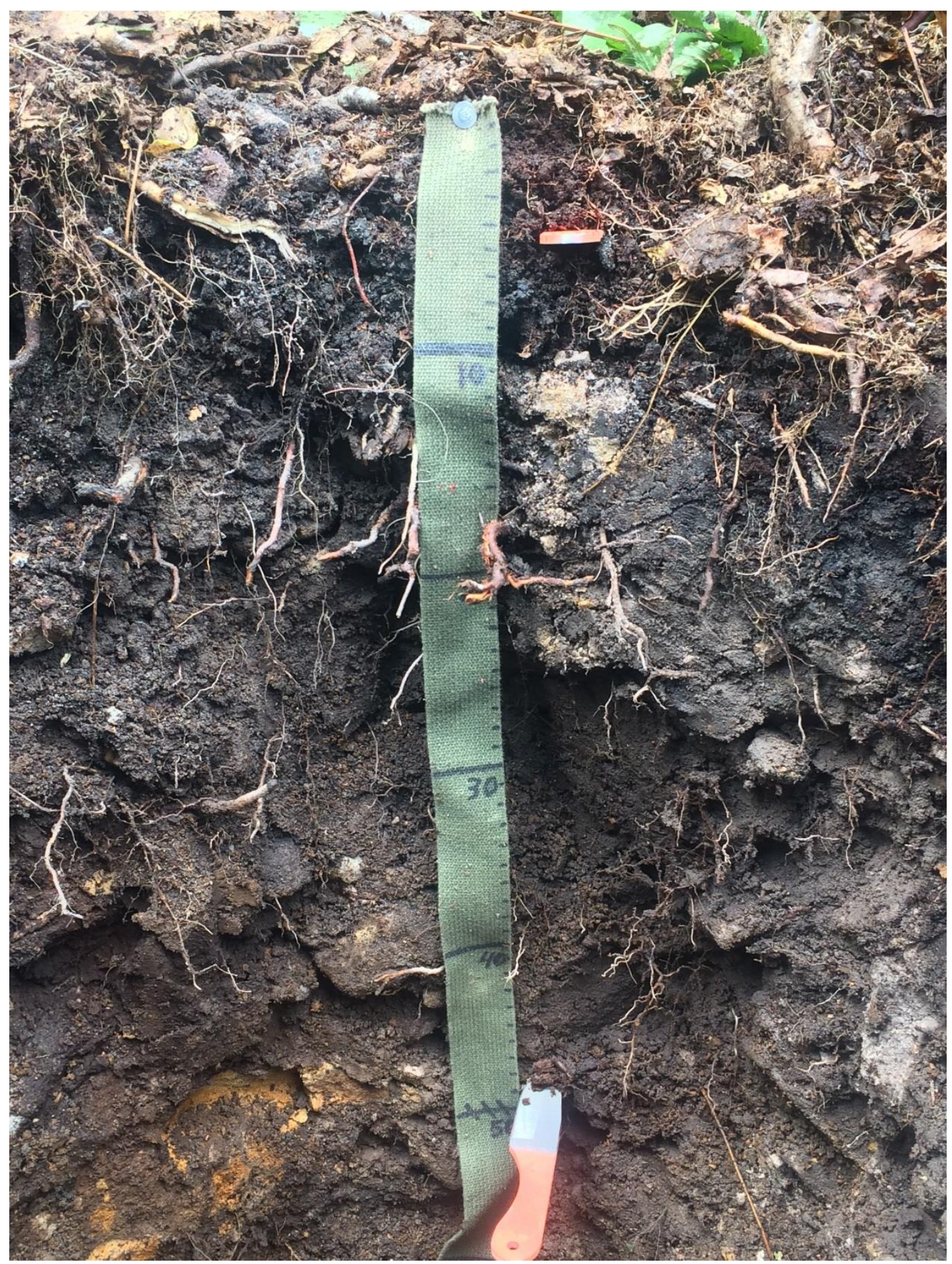

Figure 27. Soil sampling pit profile of Site 37-2 (Limed) (Pit \#3). 


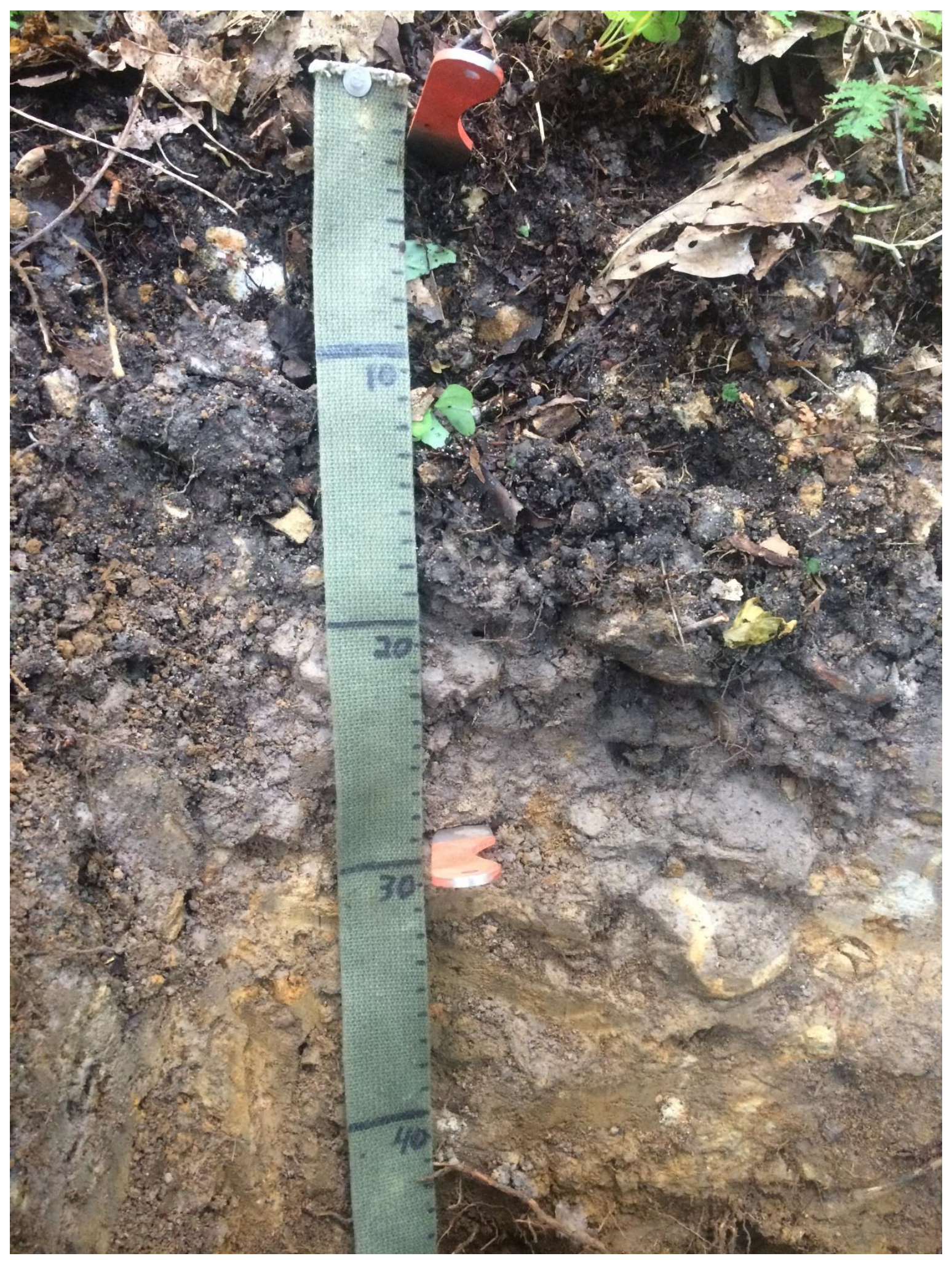

Figure 28. Soil sampling pit profile of Site 37-3 (Limed) (Pit \#1). 


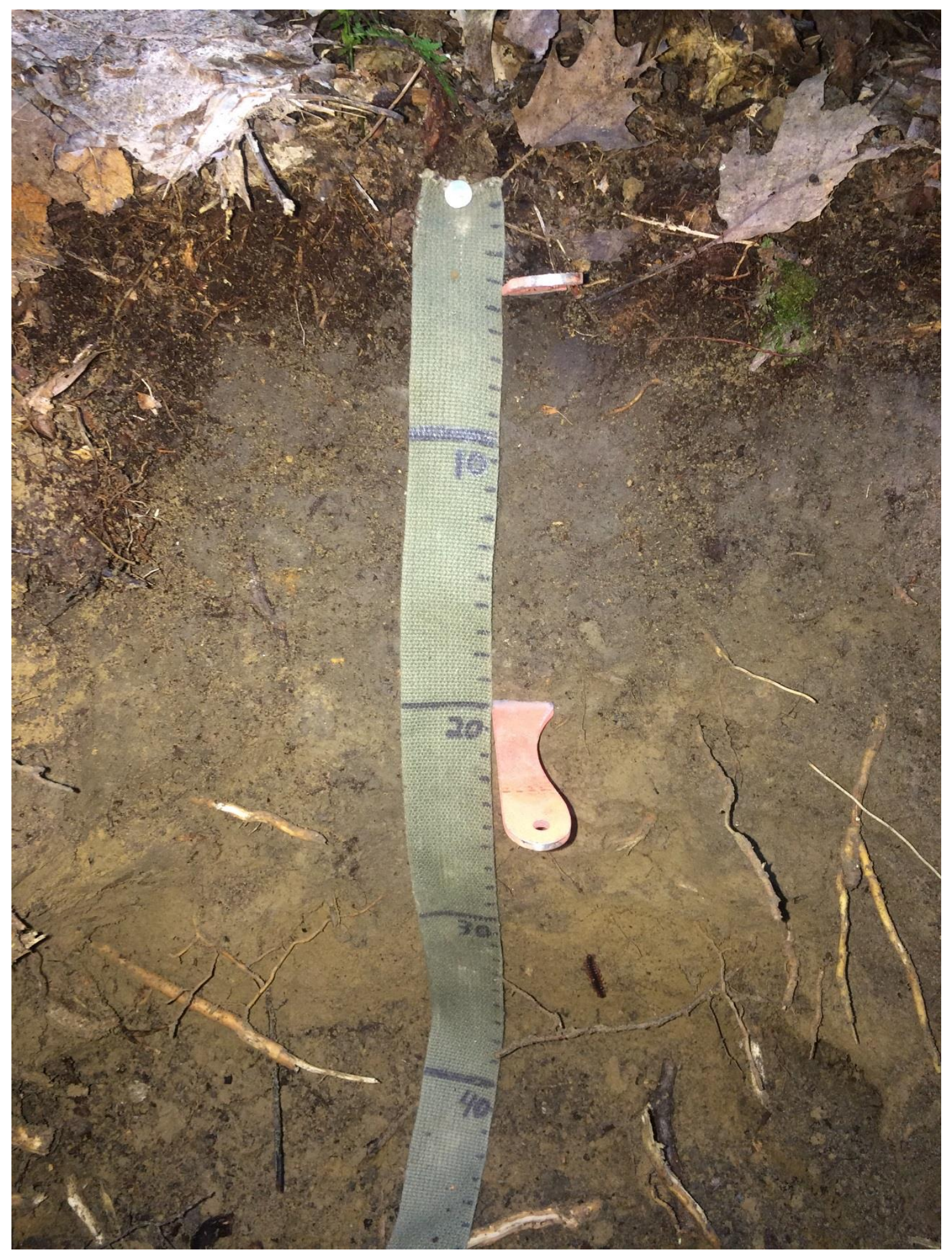

Figure 29. Soil sampling pit profile of Site 509 (Limed) (Pit \#1). 


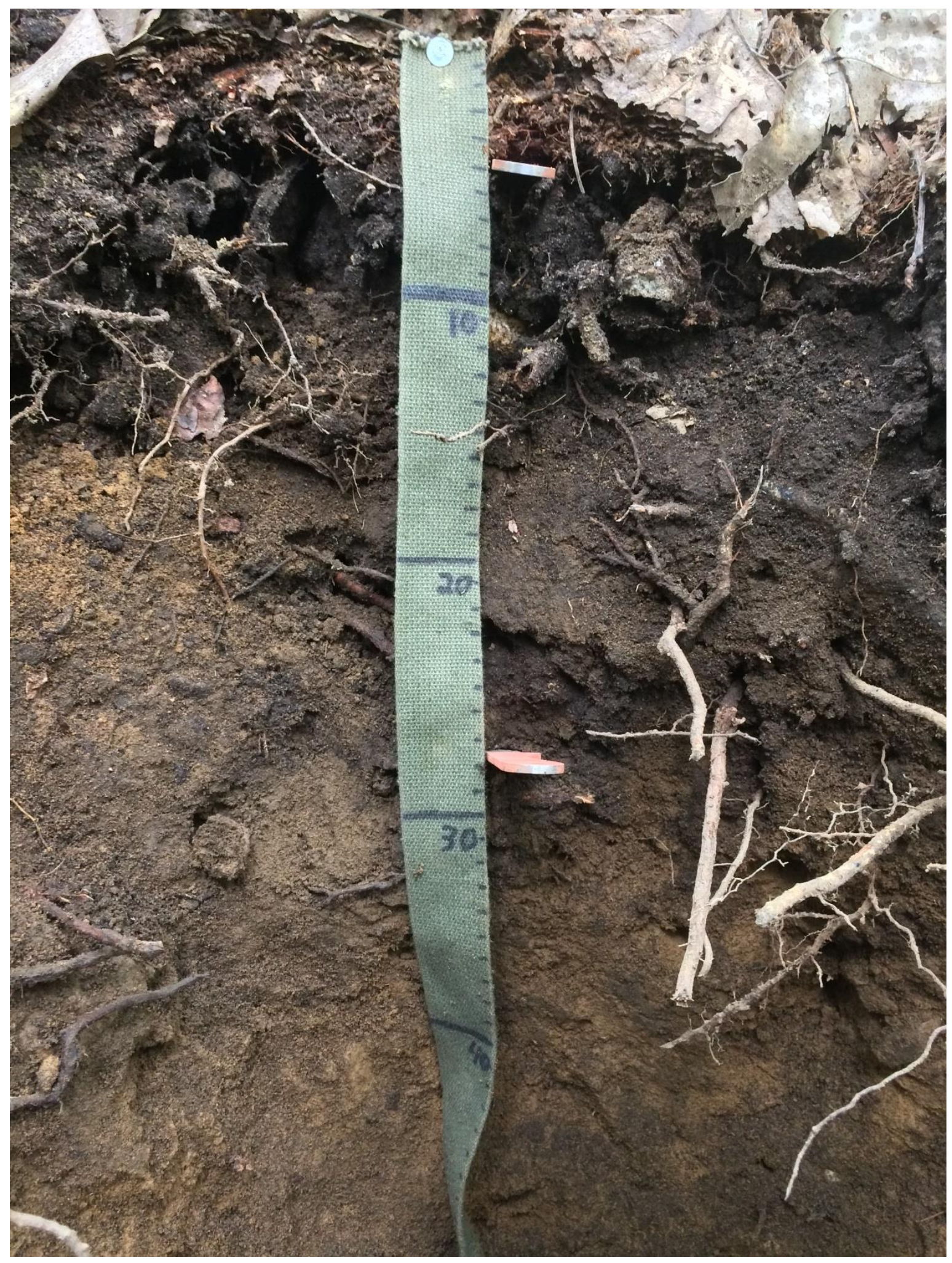

Figure 30. Soil sampling pit profile of Site E509 (Unlimed) (Pit \#5). 


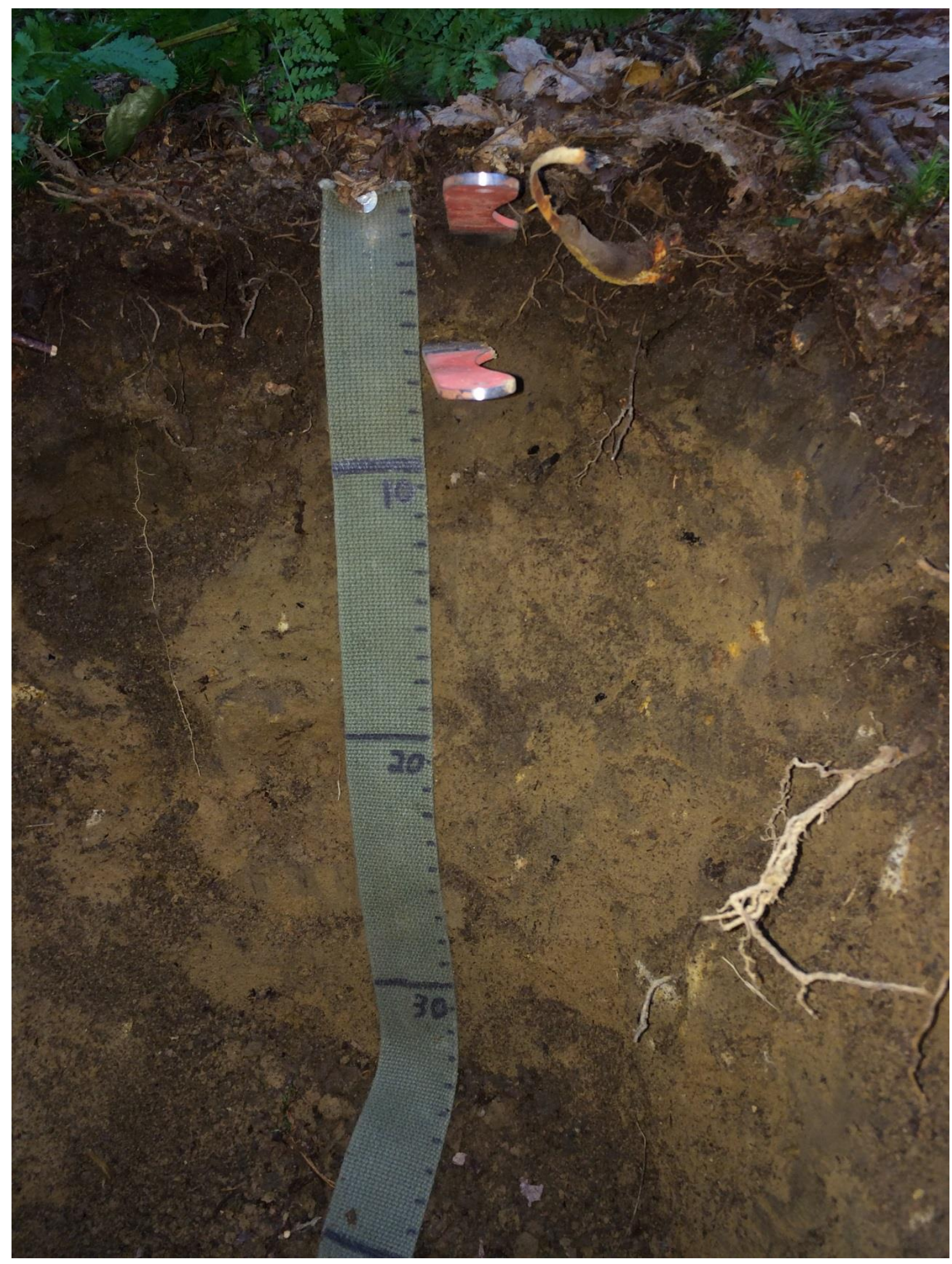

Figure 31. Soil sampling pit profile of Site 31 (Unlimed) (Pit \#5). 


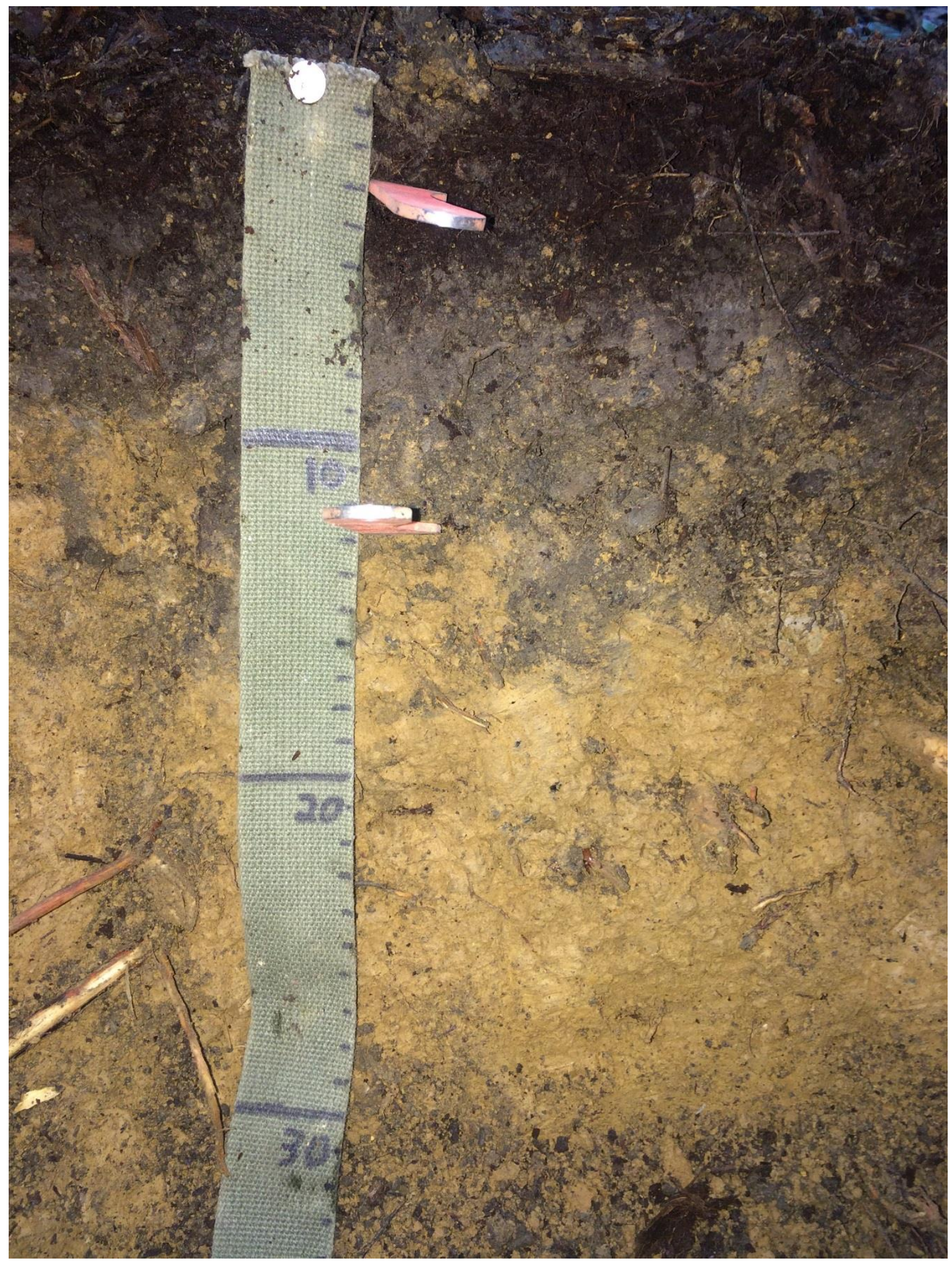

Figure 32. Soil sampling pit profile of Site 1 (Unlimed) (Pit \#4). 


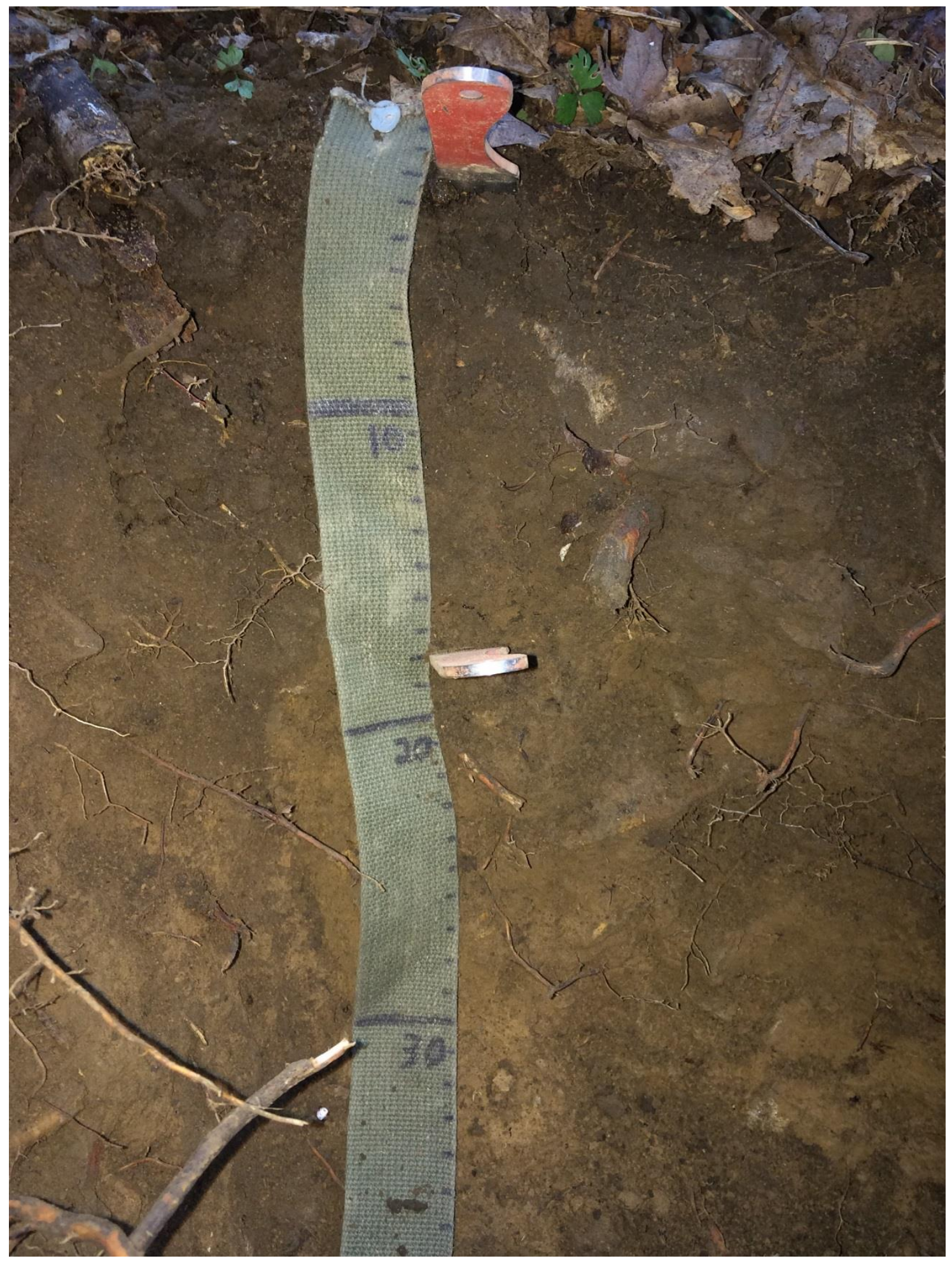

Figure 33. Soil sampling pit profile of Site 18 (Unlimed) (Pit \#3). 


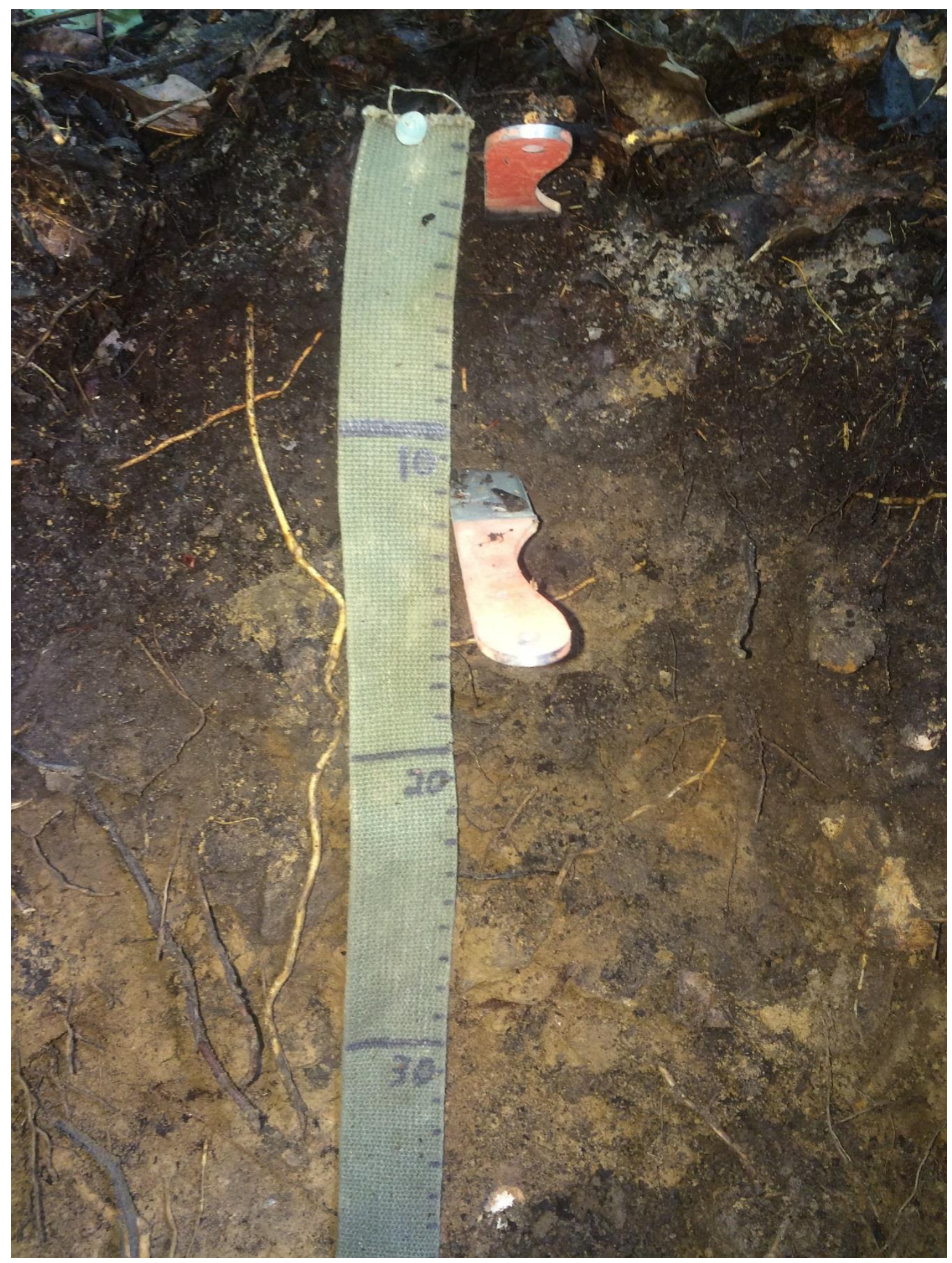

Figure 34. Soil sampling pit profile of Site 3 (Limed) (Pit \#1). 


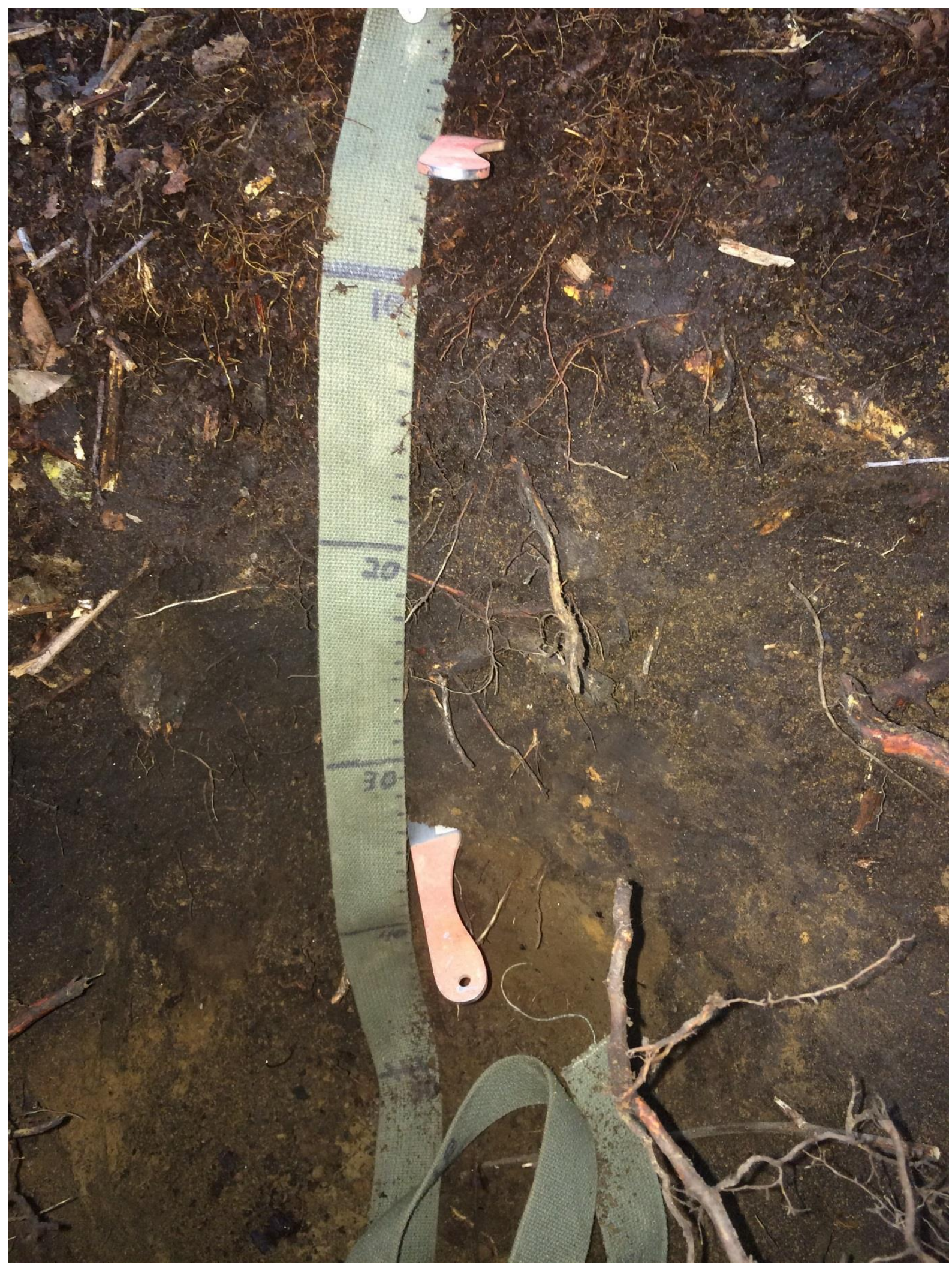

Figure 35. Soil sampling pit profile of Site 16 (Limed) (Pit \#2). 


\section{Appendix 3 - Examples of Field Sheets for Soil Descriptions.}

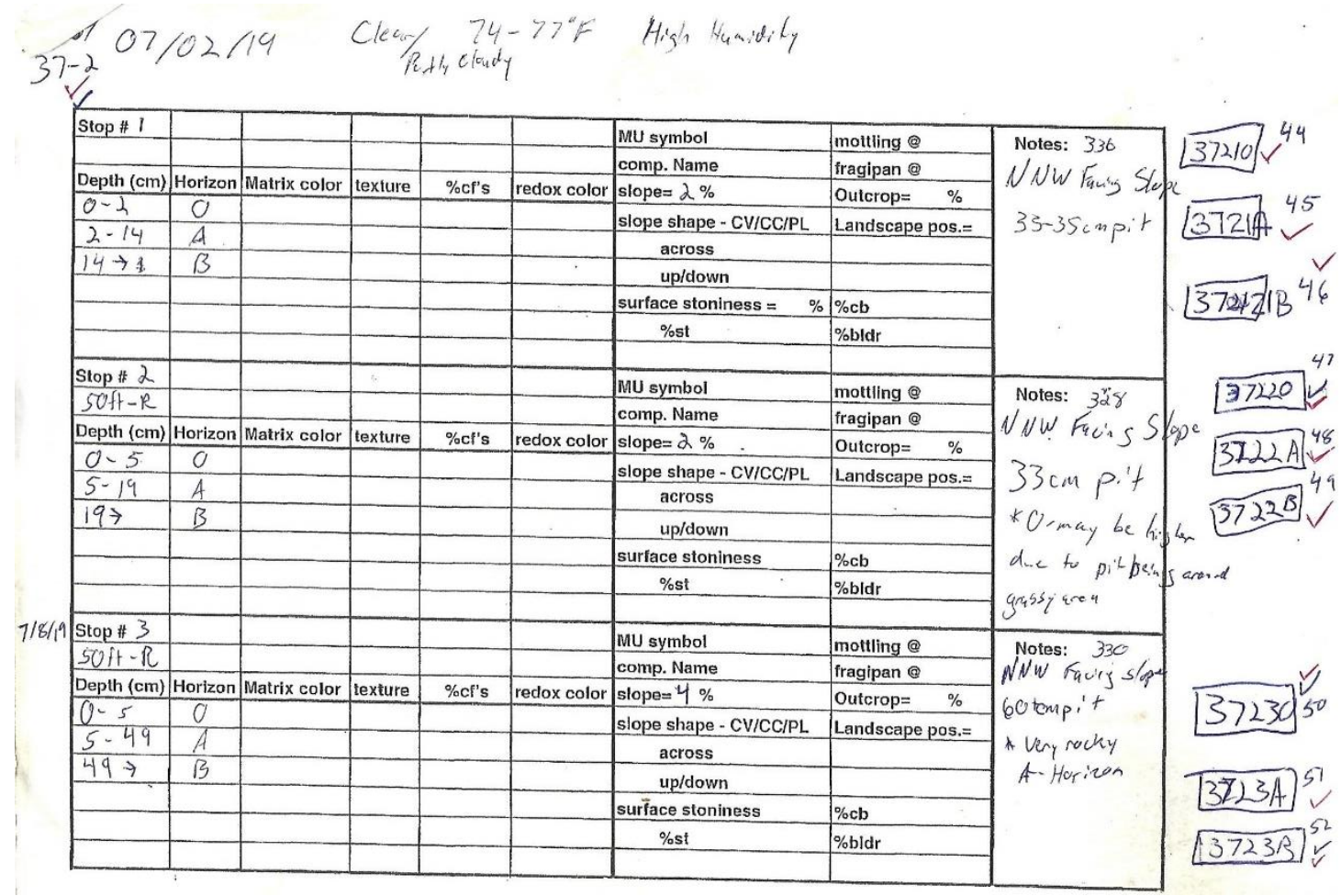

Figure 36. Example of field notes from sampling. Site 37-2 (Page 1).

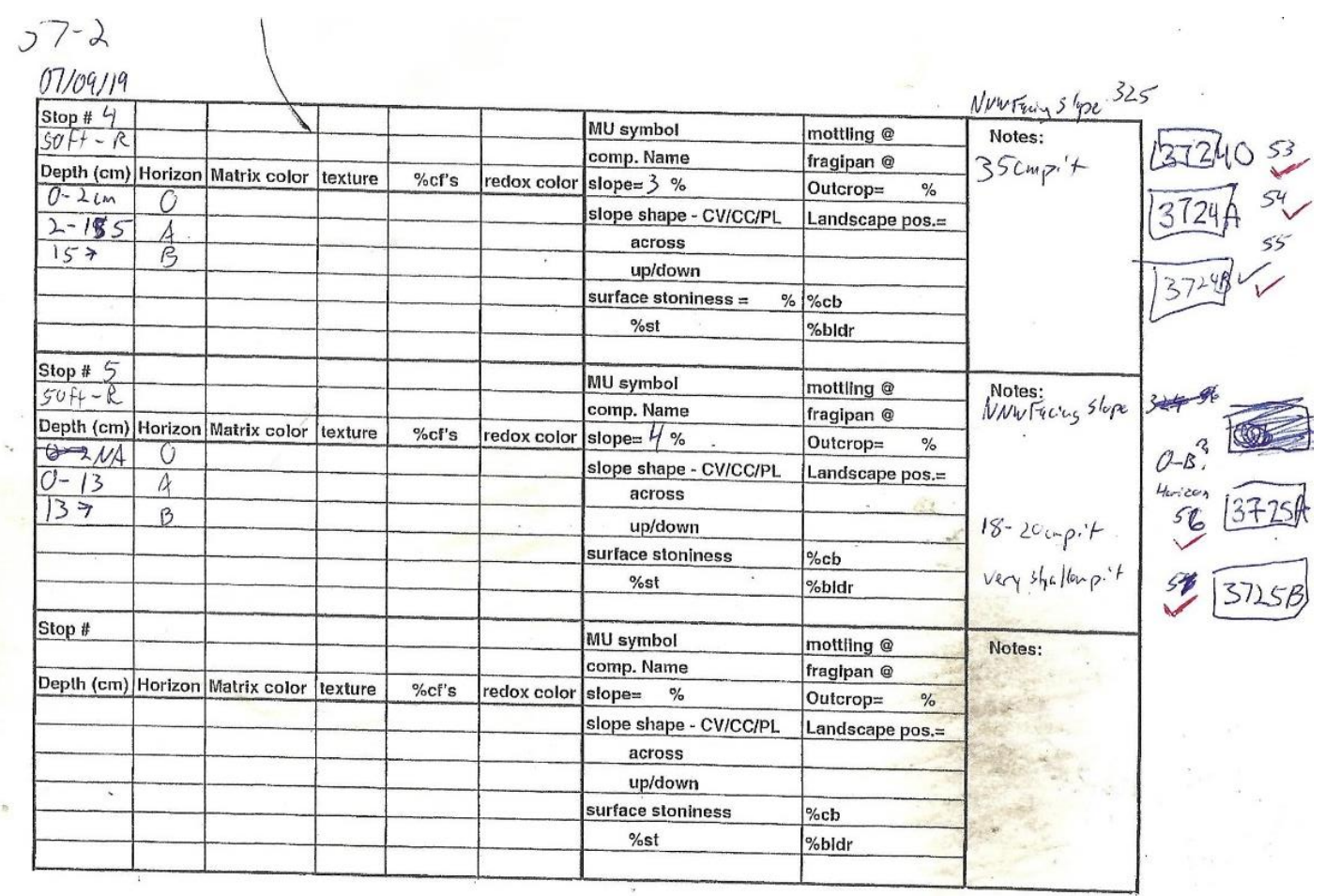

Figure 37. Example of field notes from sampling. Site 37-2 (Page 2). 
Appendix 4 - All data from the MNF Liming Study for the years 2009 and 2019. 


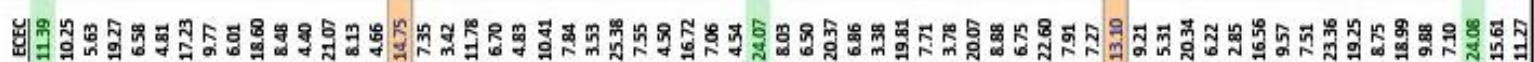

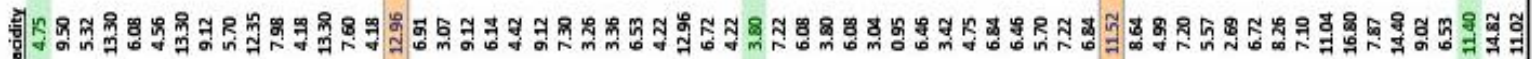

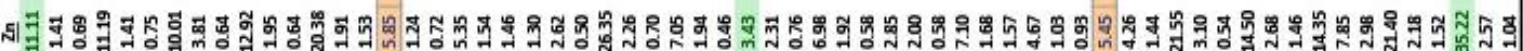

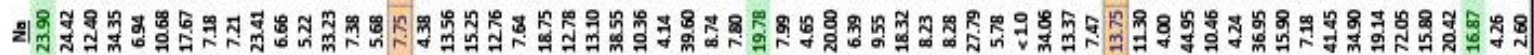

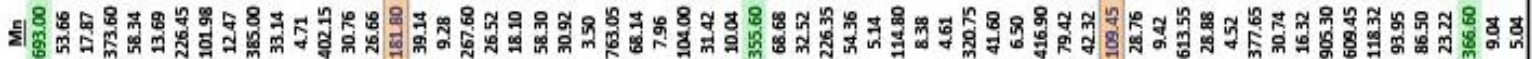

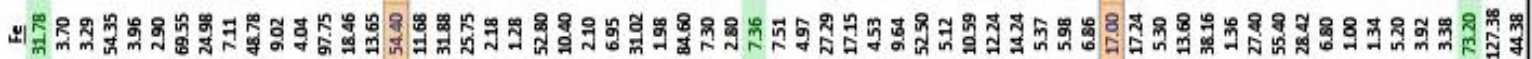

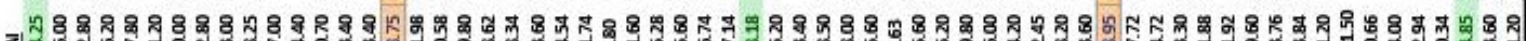

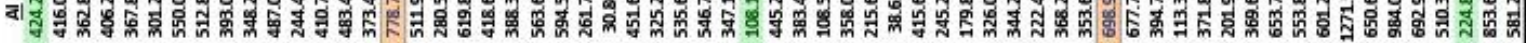

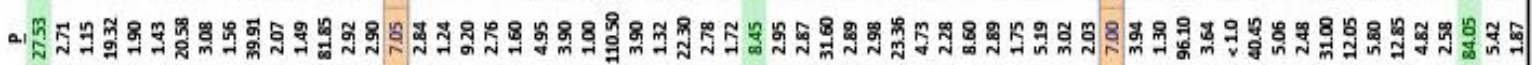

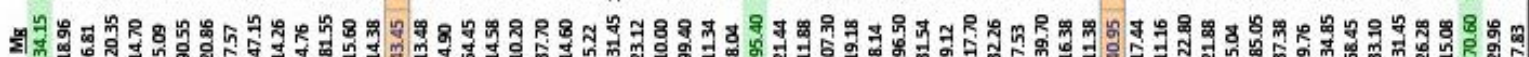

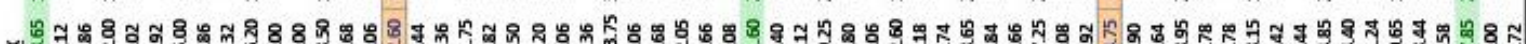

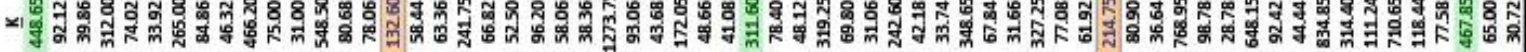

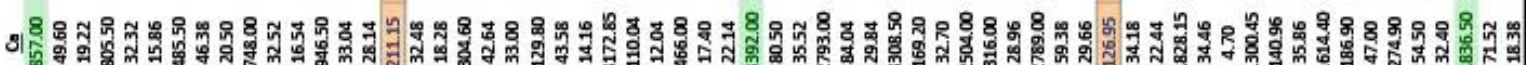

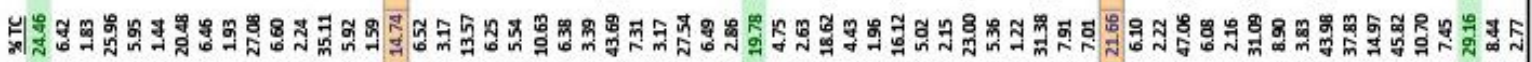

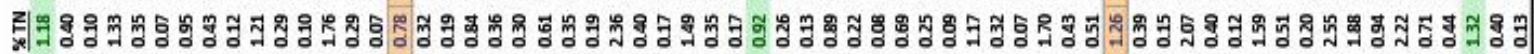

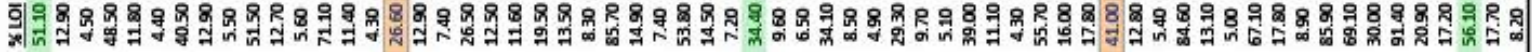

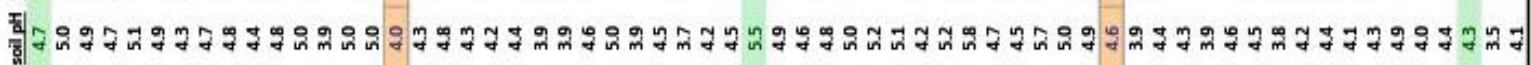

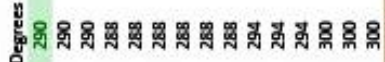

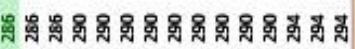
啳哭证

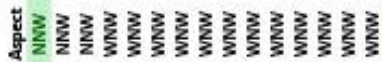

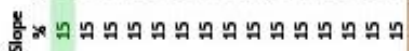

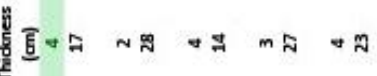
333333333333333

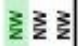

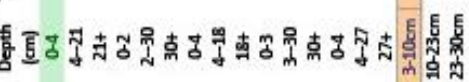

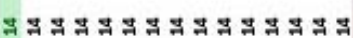

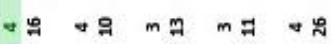

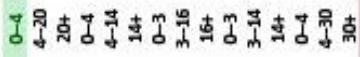
ที 臬 总 急

窟

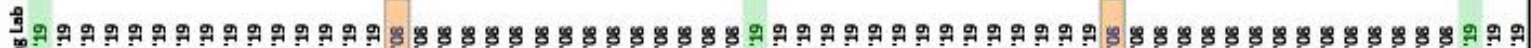

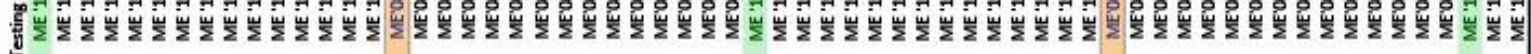

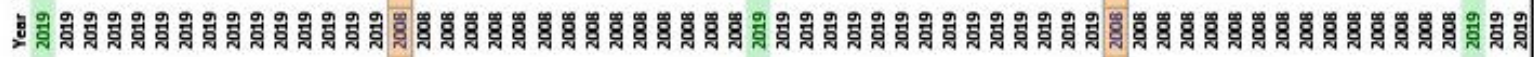

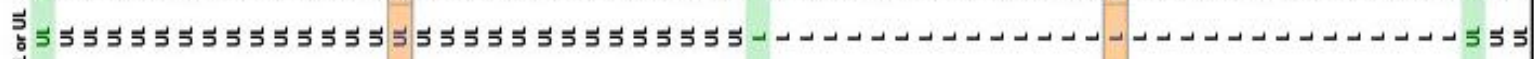

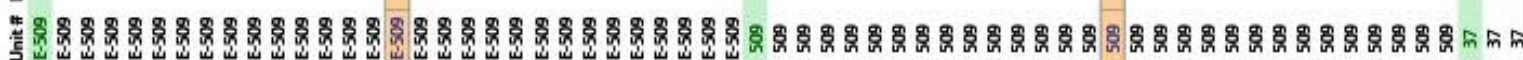

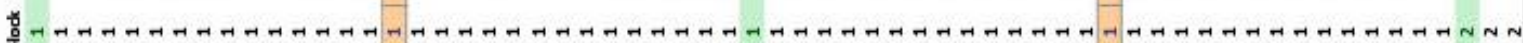

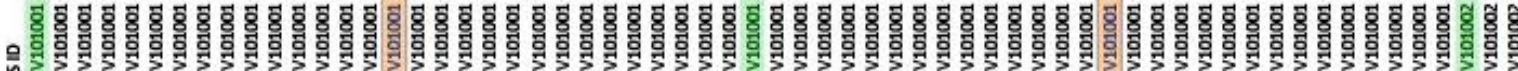

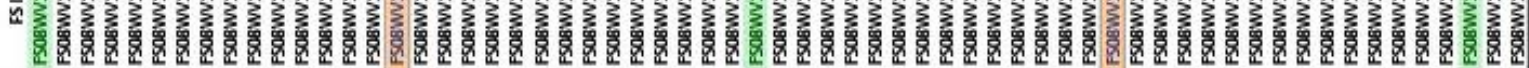

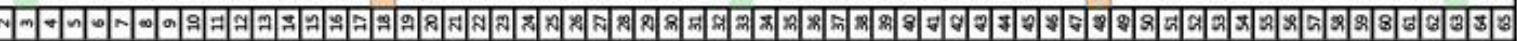
Figure 38. Spreadsheet of 2009 and 2019 Data (1/5) 


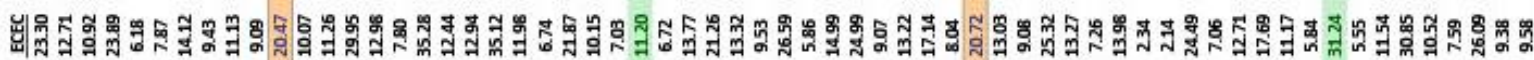

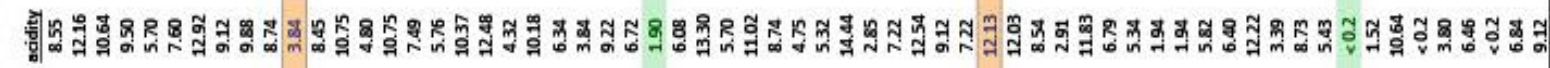

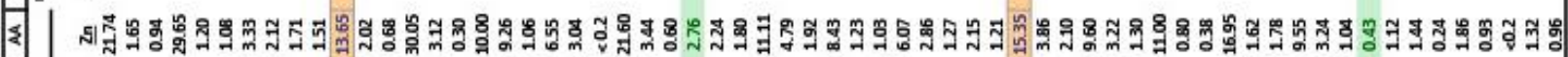

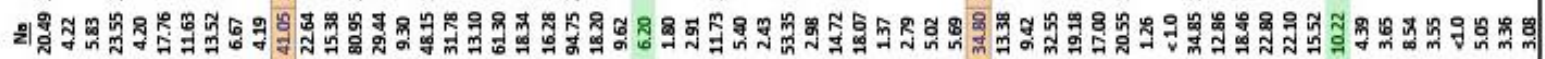

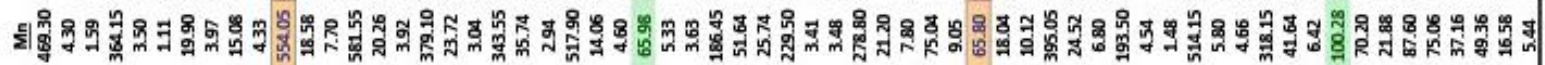

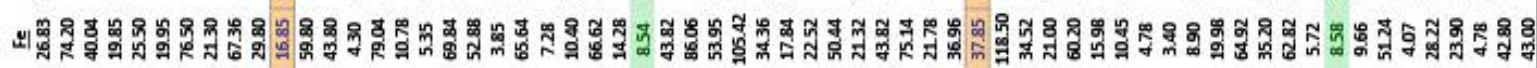

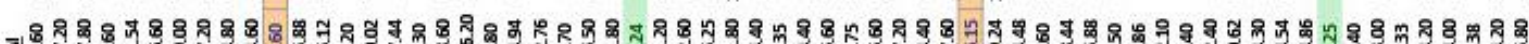

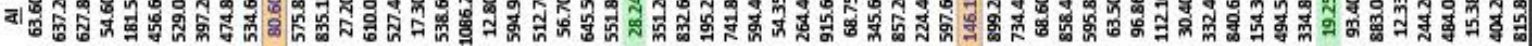

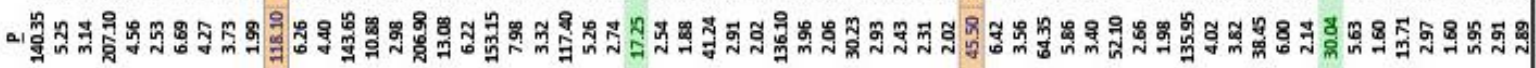

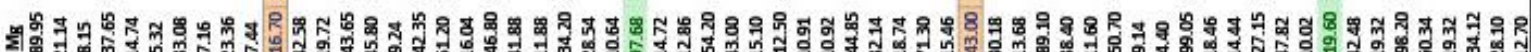

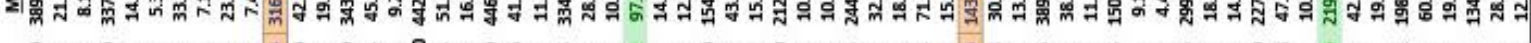

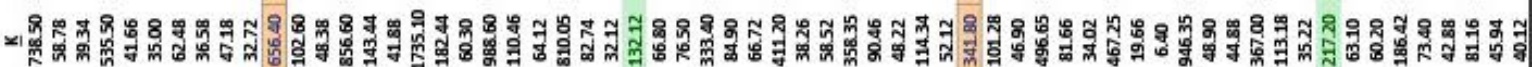

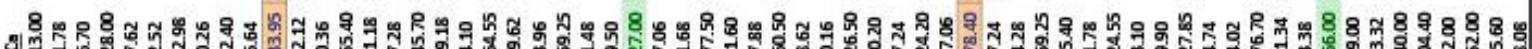

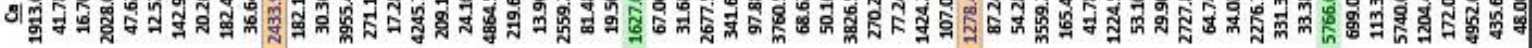

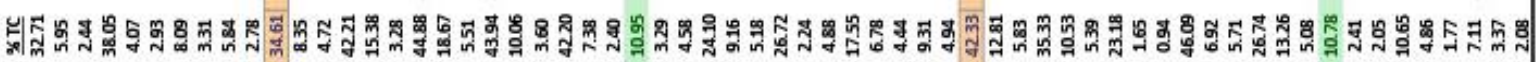

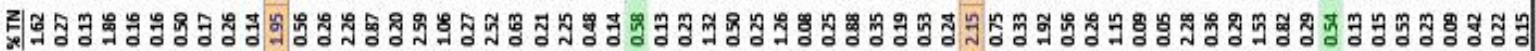

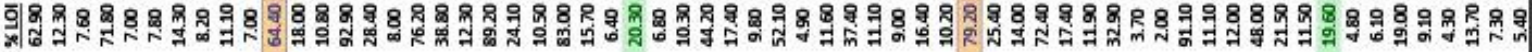

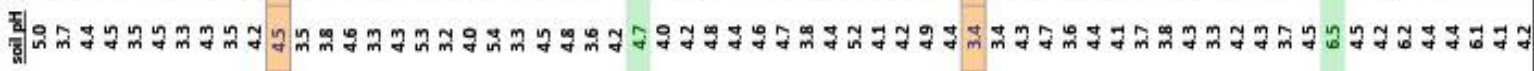

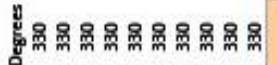

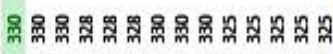

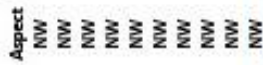

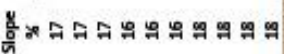

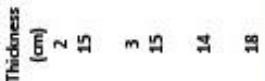

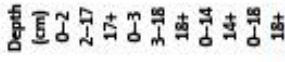

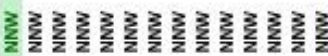

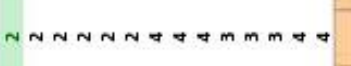

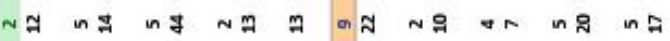

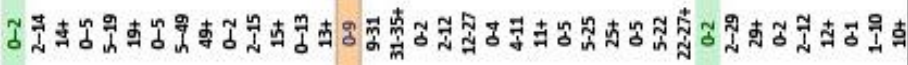
突 范 $\frac{1}{3}$

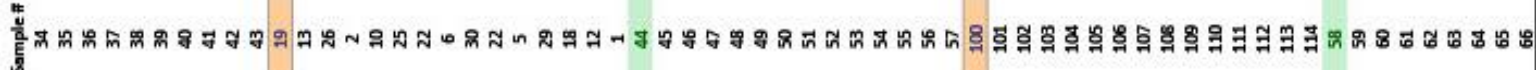

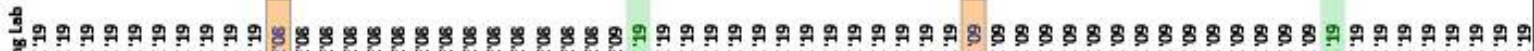

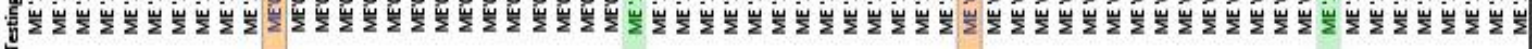

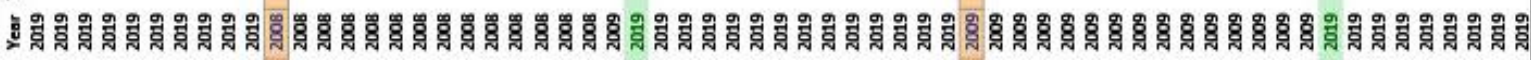

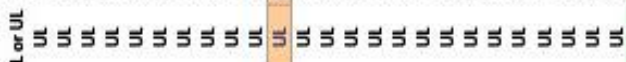

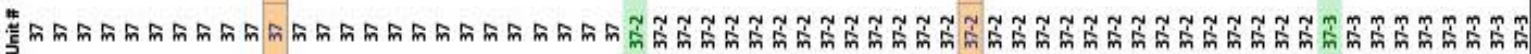
蓄

¿

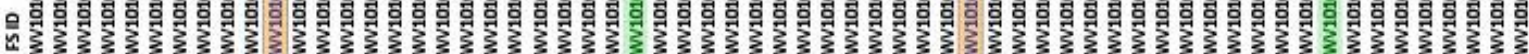

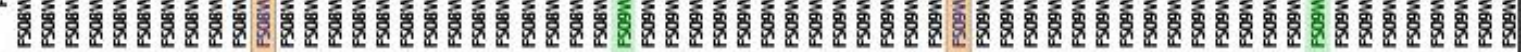

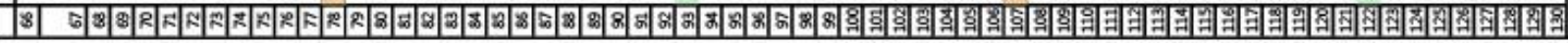

Figure 39. Spreadsheet of 2009 and 2019 Data (2/5) 


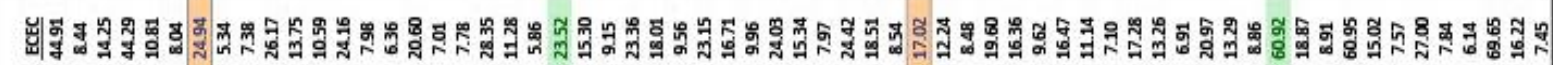

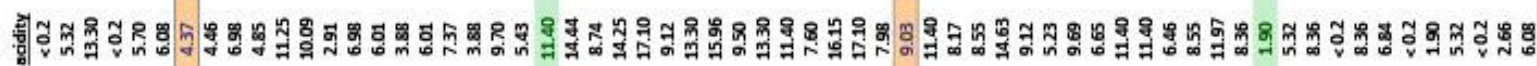

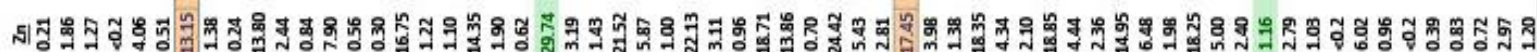

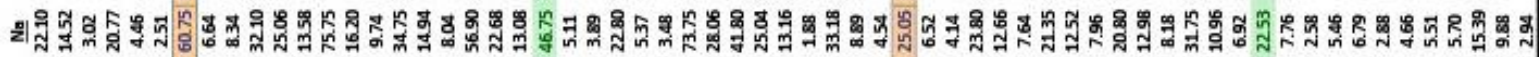

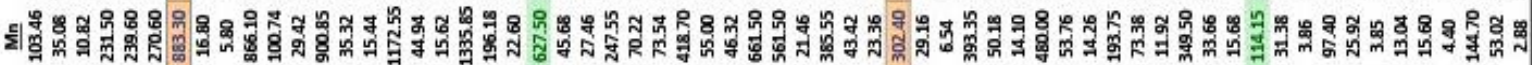

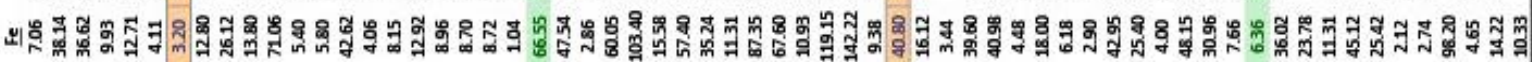

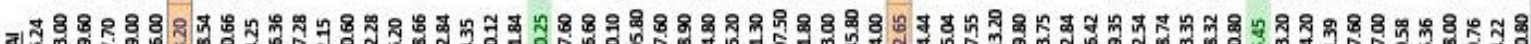

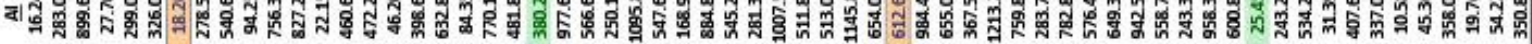

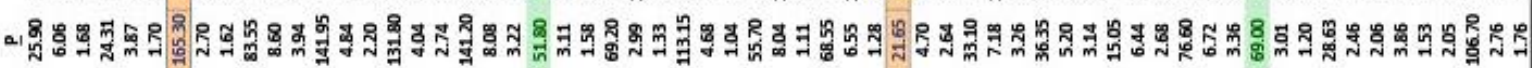

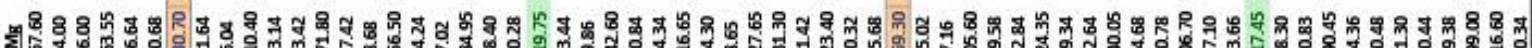

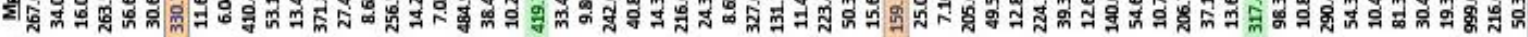

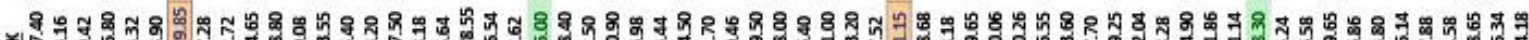

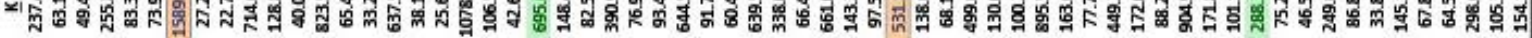

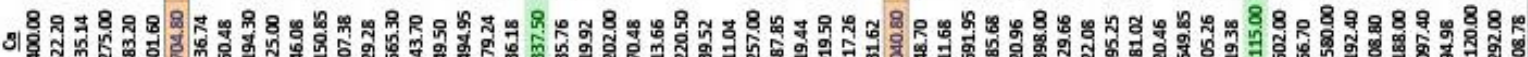

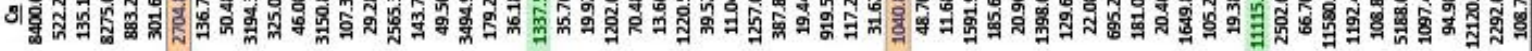

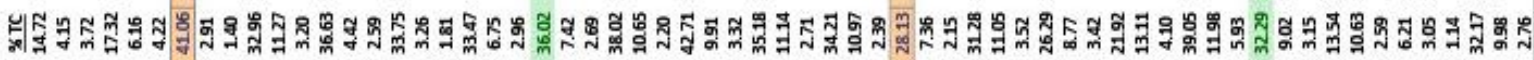

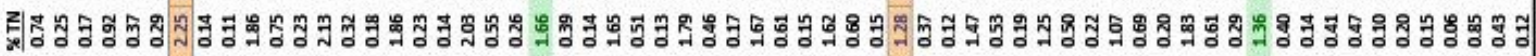

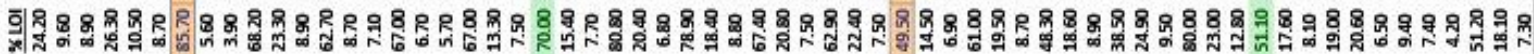

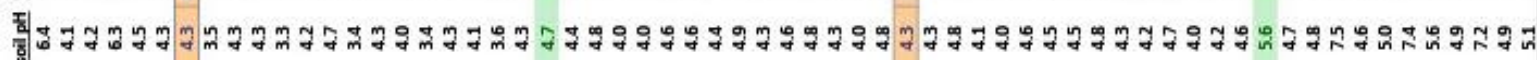

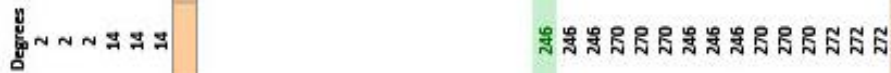

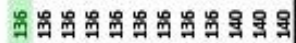

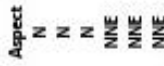

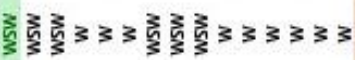

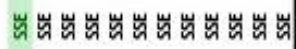

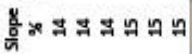

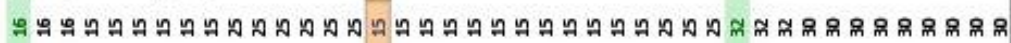

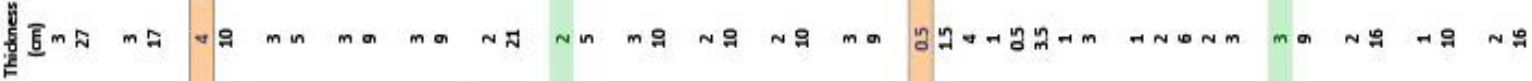

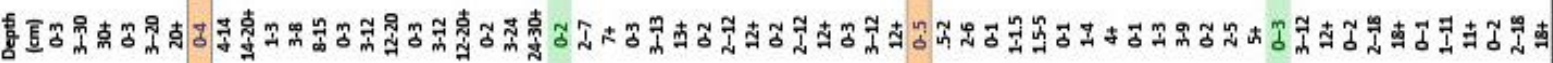

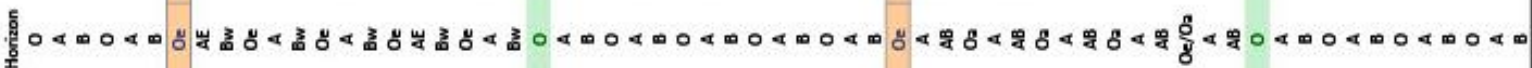
告

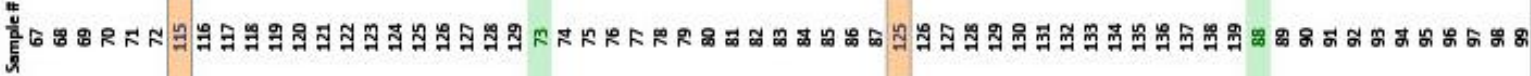

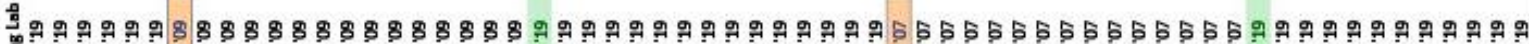

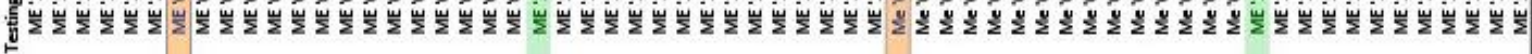

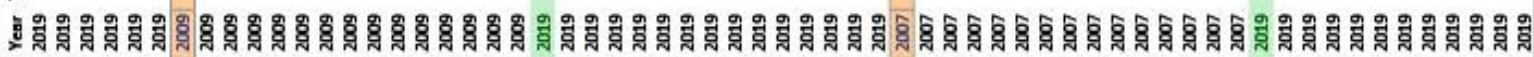
落

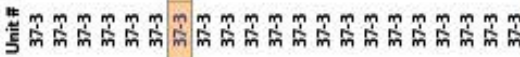

蓄

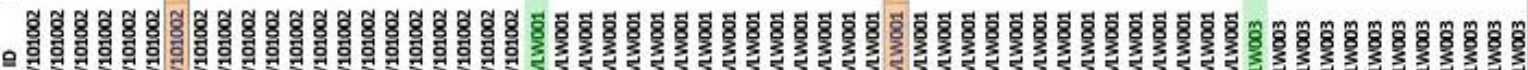

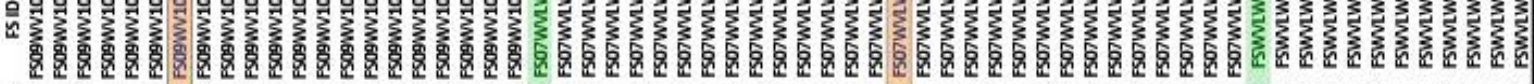

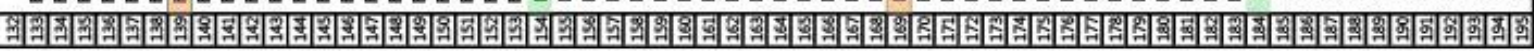

Figure 40. Spreadsheet of 2009 and 2019 Data (3/5) 


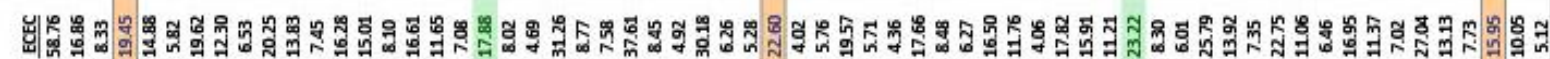

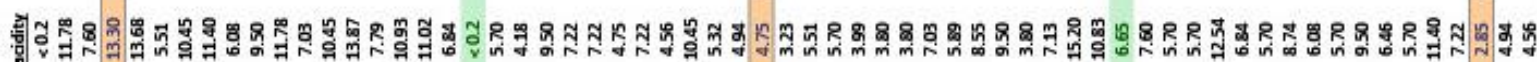

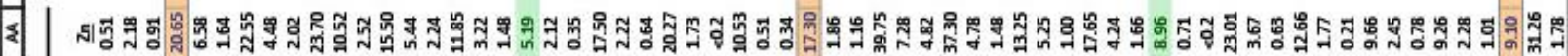

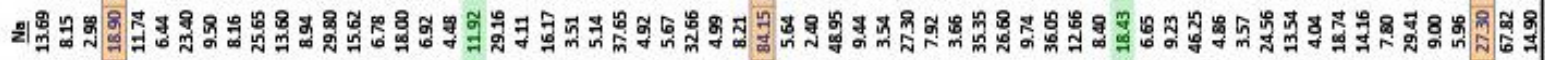

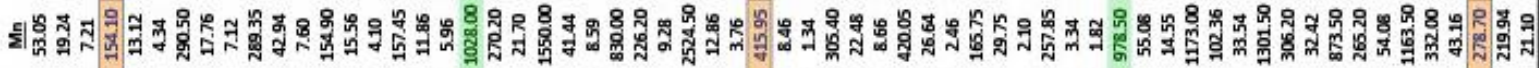

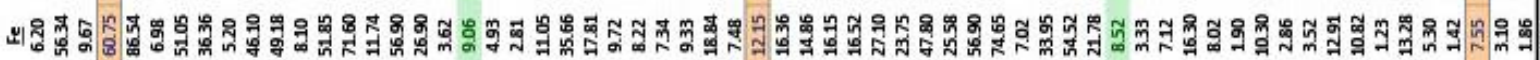
๔留 88

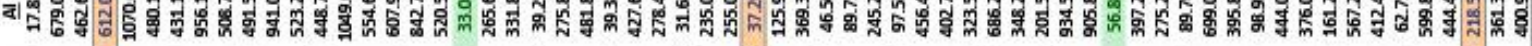

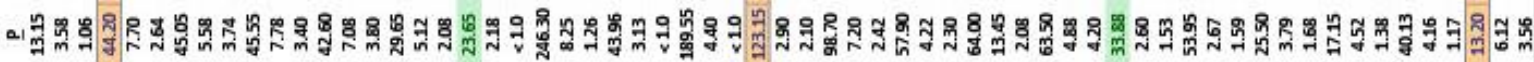

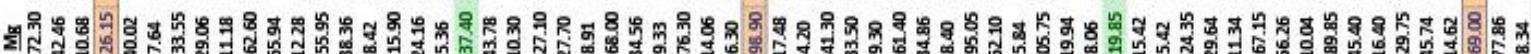

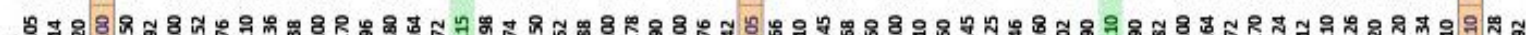

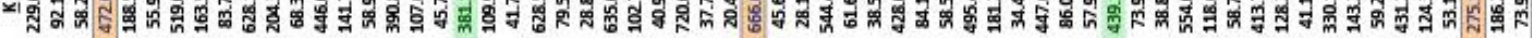

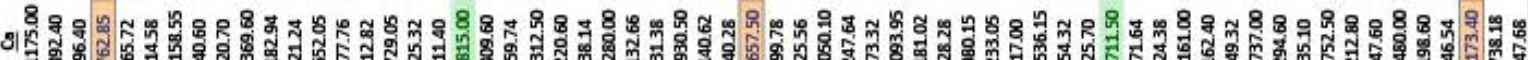
7

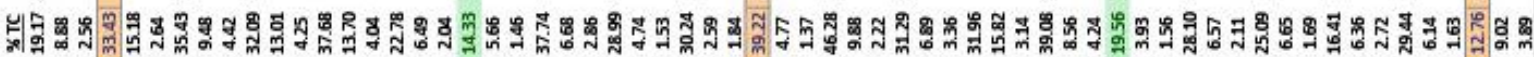

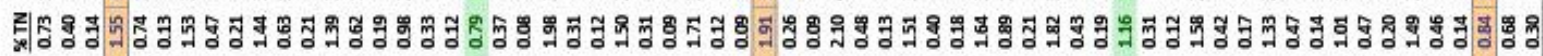

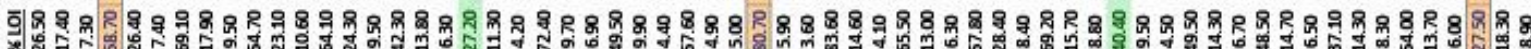

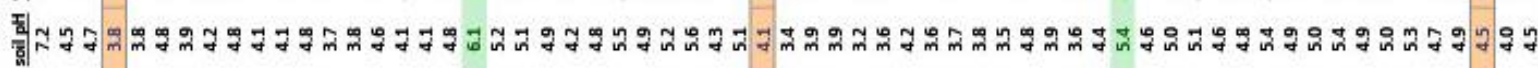

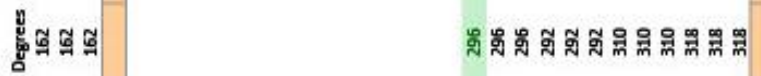

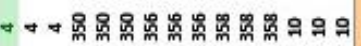

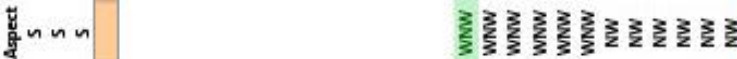
$z z z \sum_{z} \sum_{z} \sum_{2} z z z z z z z z w \omega$

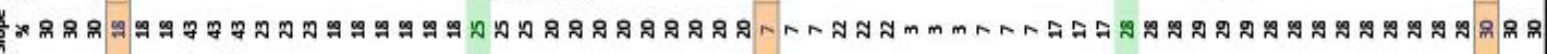

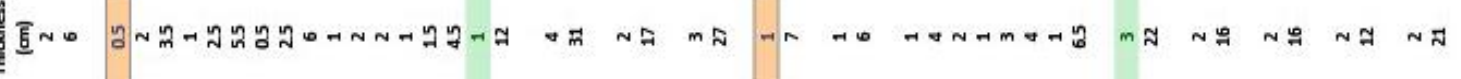

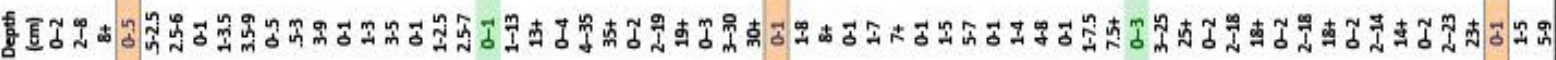

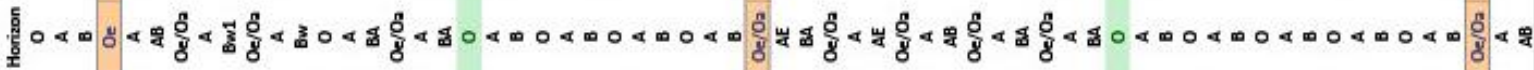
喜

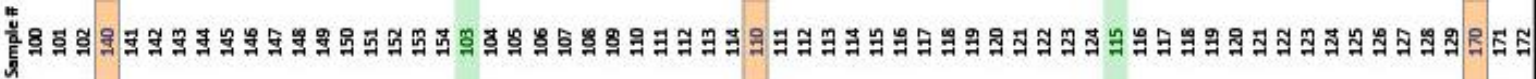

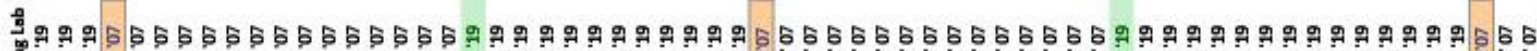

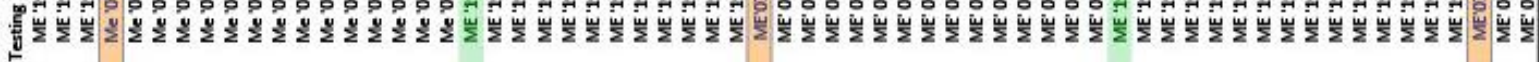

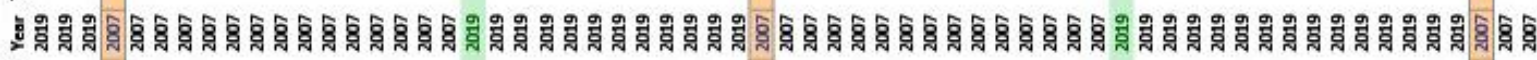

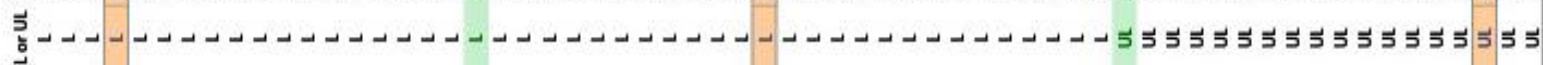
薄mmmmmmmmmmmmmmm 䔂 $m m$

Figure 41. Spreadsheet of 2009 and 2019 Data (4/5) 


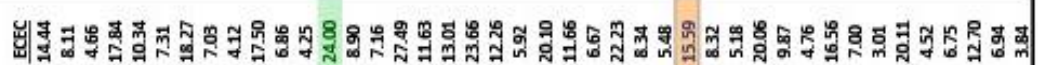

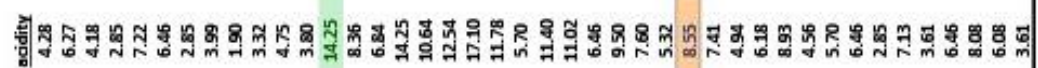

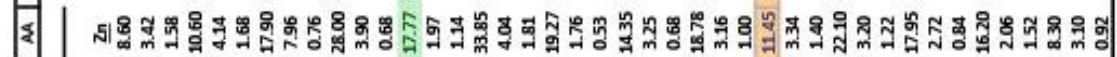

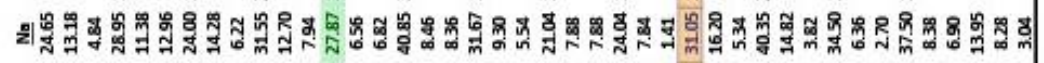

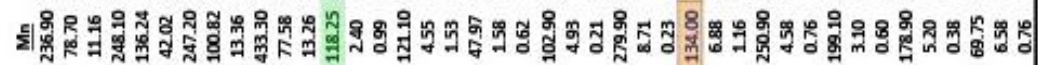

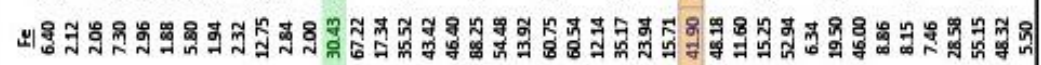

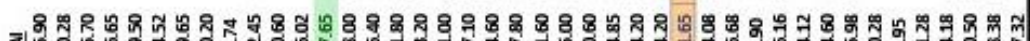

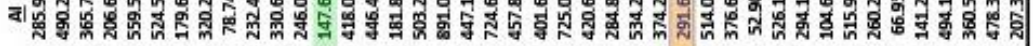

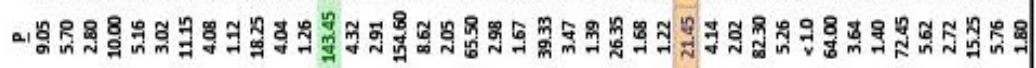

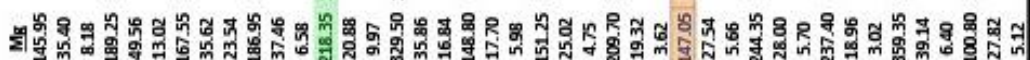

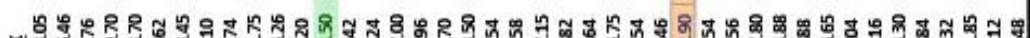

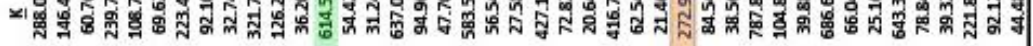

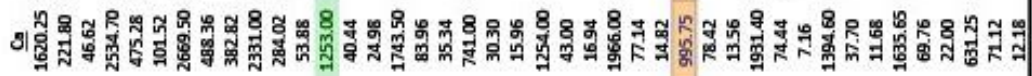

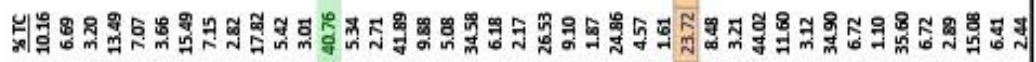

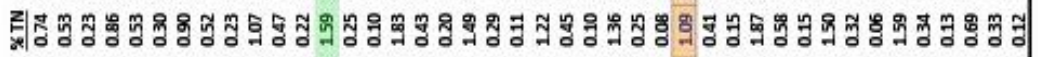

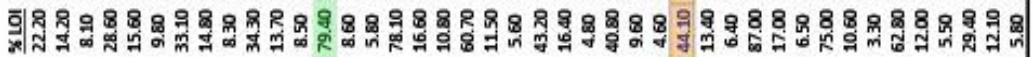

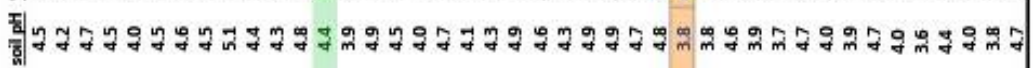

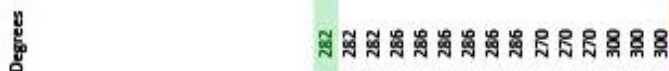

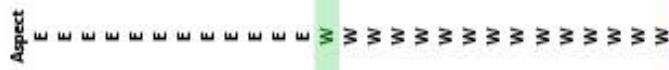

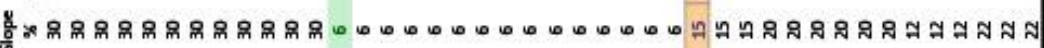

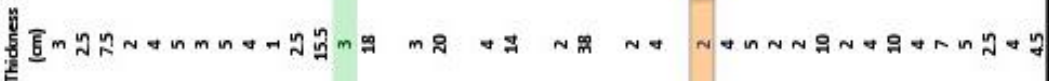

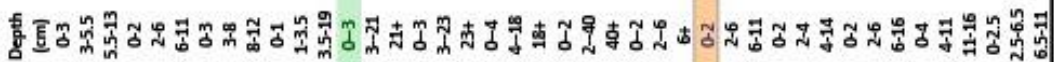

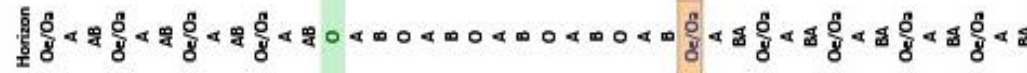

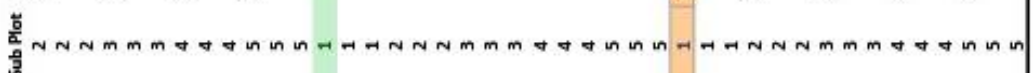

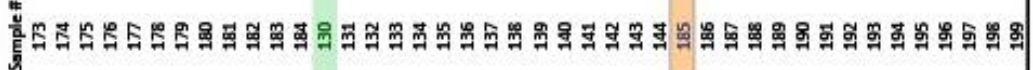

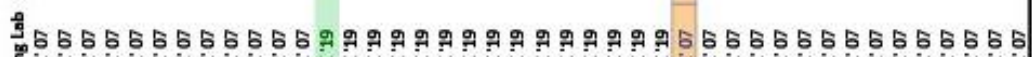

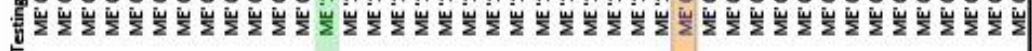

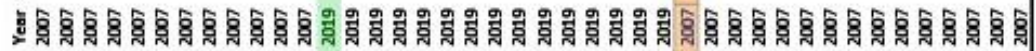

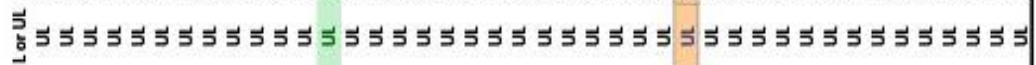

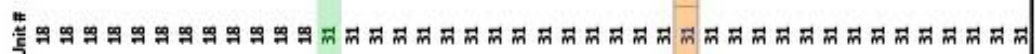

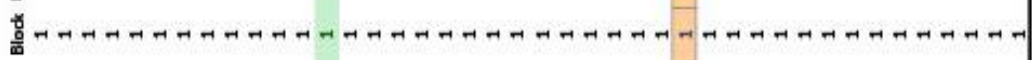

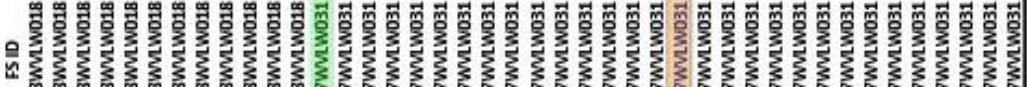

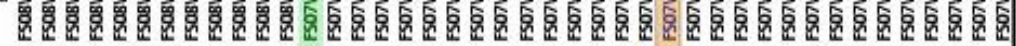
汿 Figure 42. Spreadsheet of 2009 and 2019 Data (5/5) 


\section{Appendix 5 - Statistical Codes used for Analysis}

Table 66. Statistical codes for the analysis of this data. These were placed in the thesis at the request of Dr. Ida Holaskova. Similar analyses will be performed on data in subsequent samplings so reminders of how this was done will be critical in the future.

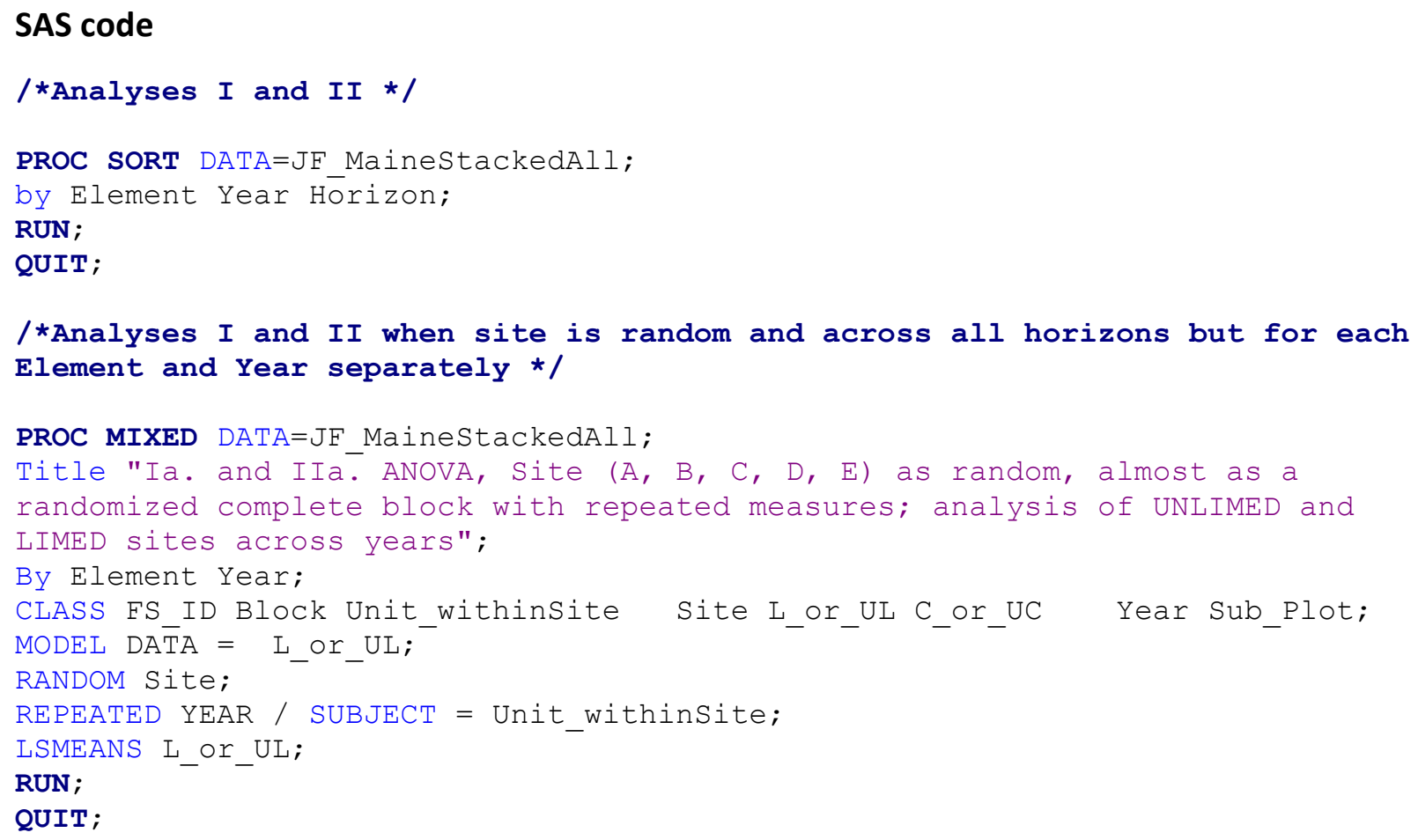


Title "Ib. adn IIb. ANOVA, Site (A, B, C, D, E) as fixed, analysis of UNLIMED and LIMED sites across years";

By Element Year Horizon;

CLASS FS_ID Block Unit_withinSite Site L_or_UL C_or_UC Year Sub_Plot;

MODEL DATA = L_or_UL Site L_or_UL*Site;

SLICE L_or_UL $\bar{S} i t \bar{e} /$ sliceby=L_or_UL adjust=tukey lines ;

RUN;

QUIT;

PROC PRINT Data=SignLetters;

RUN;

QUIT;

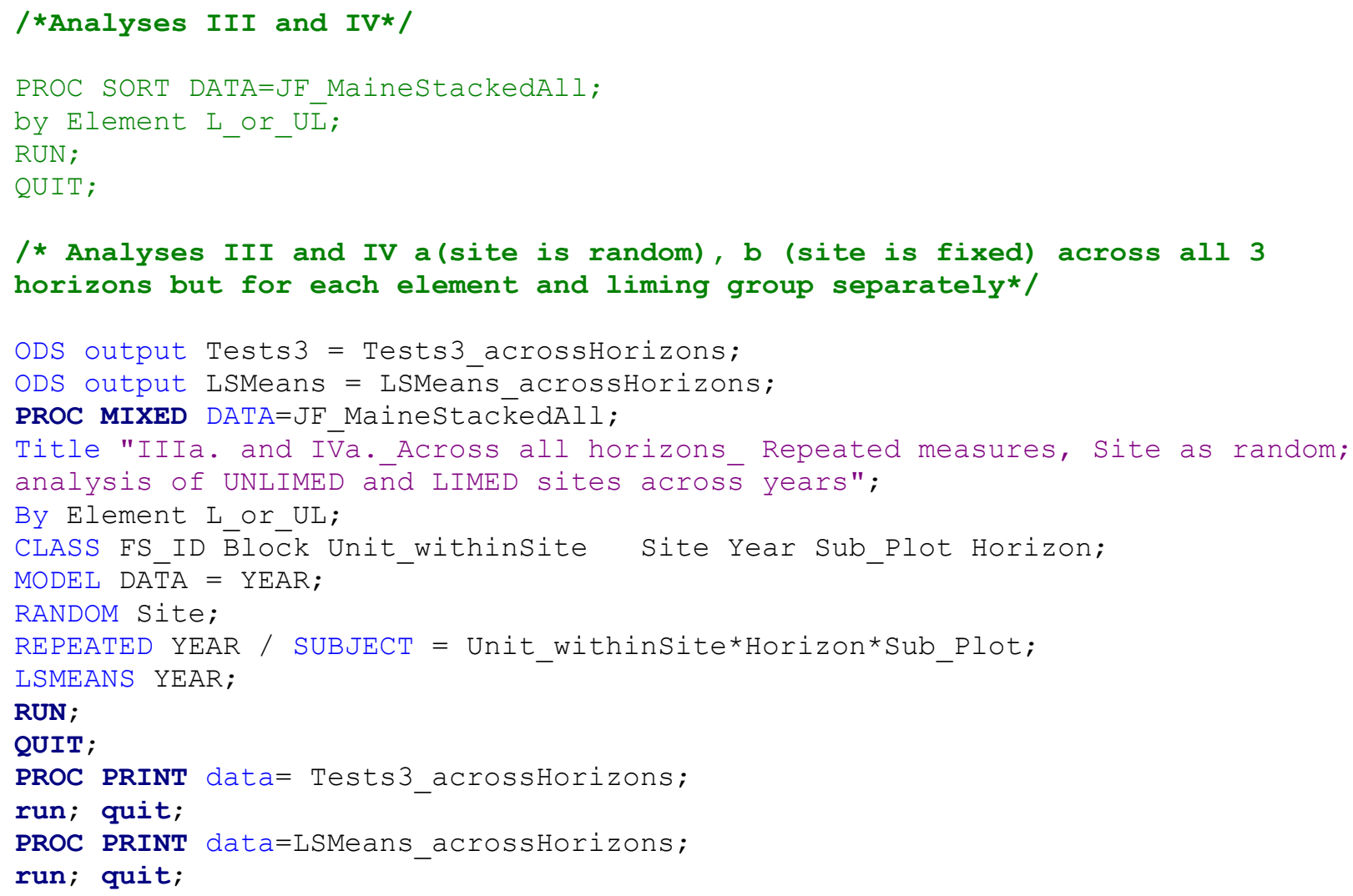

/*Analyses III and IV when site is random, and for each Element, liming level and horizon separately*/

PROC SORT DATA=JF MaineStackedAll;

by Element L_or_Ū Horizon;

RUN;

QUIT;

ODS output Tests3 = Tests3_byHorizons;

ODS output LSMeans = LSMeañs_byHorizons;

PROC MIXED DATA=JF MainestackedAll;

Title "IIIa and IVāe Each horizon separately_ Repeated measures, Site as random; analysis of UNLIMED and LIMED sites across years";

By Element L_or_UL Horizon; 
CLASS FS_ID Block Unit_withinSite Site Year Sub_Plot;

MODEL DATA = YEAR;

RANDOM Site;

REPEATED YEAR / SUBJECT = Unit_withinSite*Sub_Plot;

LSMEANS YEAR;

RUN;

QUIT;

PROC PRINT data= Tests3 byHorizons;

run; quit;

PROC PRINT data=LSMeans_byHorizons;

/*Analyses III and IV when site is fixed, across all horizons, for each Element and liming level separately*/

ODS OUTPUT SliceLines=SignLetters_acrossHorizons;

ODS output Tests3 = Tests3_across $\bar{H}$ orizons;

PROC glimmix DATA=JF Maine $\bar{S}$ tackedAll;

Title "IIlo. and IVb. Across all horizons ANOVA, Site (A, B, C, D, E) as

fixed, analysis of UNLIMED and LIMED sites across years";

By Element L_or_UL;

CLASS FS_ID Block Unit_withinsite Year Sub_Plot Horizon;

MODEL DATA = Year Unit withinSite Year*Unit withinsite;

RANDOM YEAR / SUBJECT = Unit withinSite*Sub $\bar{P} l$ ot*Horizon;

SLICE Year*Unit_withinSite/ sliceby=Year àdjust=tukey lines ;

SLICE Year*Unit_withinSite/ sliceby=Unit_withinsite adjust=tukey lines ;

RUN ;

QUIT;

Proc print data= Tests3_acrosshorizons;

run; quit;

Proc print data= SignLetters_acrossHorizons;

run; quit;

/*Analyses III and IV when site is fixed and for each Element, liming level and horizon separately*/

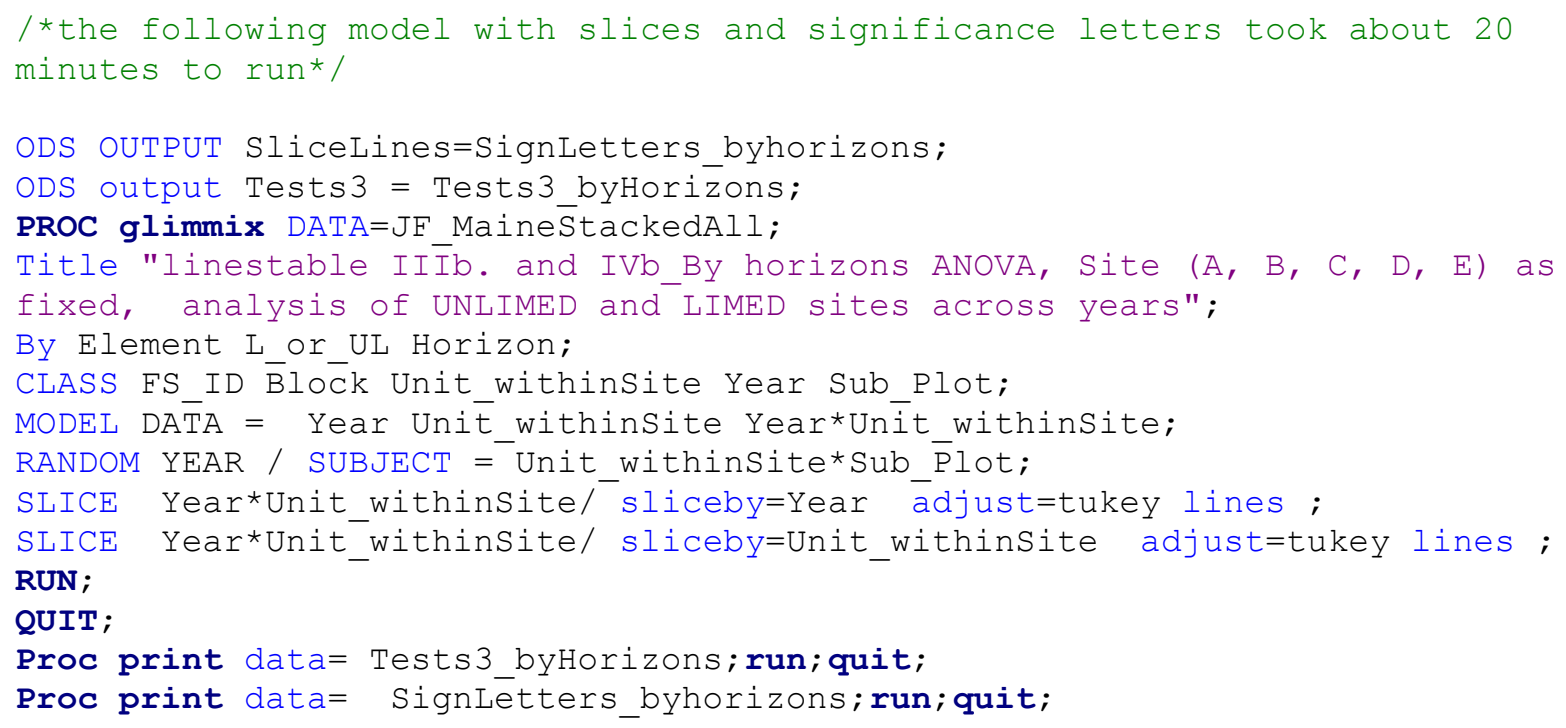

